\author{
UNIVERSIDADE DE SÃO PAULO \\ MUSEU DE ARQUEOLOGIA E ETNOLOGIA \\ PROGRAMA DE PÓSGRADUÇÃO EM ARQUEOLOGIA
}

\title{
CONTRIBUIÇÃO À ARQUEOLOGIA GUARANI: ESTUDO DO SÍTIO RÖPKE
}

\author{
André Luis R. Soares
}

Tese apresentada ao Programa de PósGraduação em Arqueologia, do Museu de Arqueologia e Etnologia da Universidade de São Paulo, para obtenção do título de Doutor em Arqueologia.

Orientador: Prof. Dr. José Luiz de Morais

São Paulo 


\section{UNIVERSIDADE DE SÃO PAULO \\ MUSEU DE ARQUEOLOGIA E ETNOLOGIA \\ PROGRAMA DE PÓSGRADUÇÃO EM ARQUEOLOGIA}

\section{CONTRIBUIÇÃO À ARQUEOLOGIA GUARANI: ESTUDO DO SÍTIO RÖPKE}

André Luis R. Soares

São Paulo 


\section{DEDICATÓRIA}

\section{A Adão Pereira Soares (in memoriam),}

À Clélia Ramos Soares e família, À Gertha Corrêa.

Dedico esta tese àqueles que acreditam na solidariedade, na caridade e em todas as manifestações do amor incondicional. 


\section{AGRADECIMENTOS}

Uma tese de doutorado, mesmo sendo um trabalho individual, não pode ser realizada sem o auxílio, orientação, apoio e confiança de diversas pessoas ou instituições, a quem gostaria de agradecer:

- em primeiro lugar, ao meu orientador, Professor Livre-Docente José Luiz de Morais, pela orientação, paciência e tolerância;

- à Universidade de São Paulo, através do Museu de Arque ologia e Etnologia, por ter me aceitado em seu quadro discente;

- à Universidade Federal de Santa Maria (UFSM), pelo apoio financeiro, concedido sob forma de bolsa de estudo (PICDT) por meio da Pró-Reitoria de Pós-Graduação e Pesquisa, com recursos oriundos do convênio UFSM/Coordenadoria de Aperfeiçoamento do Pessoal de Ensino Superior;

- ao Professor Saul Milder, pelo acesso inicial ao seu laboratório e aos originais da escavação, através de fotos, croquis, desenhos e diário de campo;

- à Professora Doutora Dirse Kern, do Museu Paraense Emílio Goeldi, pelas análises químicas do solo, da cerâmica e auxílio em sua interpretação; e pela troca de idéias sobre as possibilidades de análise;

- ao Pedólogo Doutor Vinícius Benites e Ph.D. Beata Madari, do Embrapa/Solos do Rio de Janeiro, pelas análises do solo antropogênico por digestão total, pelos inúmeros esclarecimentos e atenção dispensados;

- ao Doutor Bruno Glaser, do Institute of Soil Science and Soil Geography, University of Bayreuth, Alemanha, pelas análises do solo antropogênico em sua Universidade e tolerância com minhas perguntas;

- ao Professor Doutor Ari Zago e Técnico Luiz Finamor, do Centro de Ciências Rurais (CCR) UFSM, pela análise de elementos disponíveis para plantas e auxílio na interpretação dos resultados;

- ao Doutor Jorge Eduardo Sarkis, do Instituto de Pesquisas Energéticas e Nucleares (IPEN) da Universidade de São Paulo (USP), pela orientação sobre as assinaturas químicas da cerâmica e pelas recepções sempre afetuosas;

- à doutoranda Irene Akemy T. Bona, do IPEN-USP, pela paciência oriental com minhas dúvidas freqüentes;

- ao Professor Doutor Shigueo Watanabe, do Laboratório de Cristais Iônicos e Filmes (LACIFID), do Instituto de Física da USP, pela realização das várias datações por 
termoluminescência, pelos textos necessários à compreensão do método e pela paciência em atender-me em seu laboratório sem hora marcada;

-à Professora Doutora Sonia Tatumi, do Laboratório de Vidros e Datação da Fundação de Tecnologia de São Paulo (FATEC) UNESP, pela atenção na realização de datações em curto espaço de tempo;

- ao professor Doutor Daniel Loponte, do CONICET, Argentina, pelo intercâmbio de informações, pelo auxílio na condução de amostras de carvão para datações no Laboratorio de Tritio y Radiocarbono (LATYR -CONICET-UNLP) em Mar Del Plata e pela gentileza cativante;

- ao Professor Doutorando Sérgio Célio Klamt, que me acolheu no Centro de Ensino e Pesquisas Arqueológicas (CEPA) UNISC, permitindo a análise do material naquela Instituição, e amavelmente abriu as portas de sua casa. O prof. Sérgio permitiu que, além de utilizar seu laboratório para minhas análises, fosse disponibilizada toda estrutura necessária para que eu me sentisse à vontade, além de custear datações de TL realizadas pela FATECUNESP. Portanto, a ele, meu agradecimento muito especial. Minha dívida jamais será paga. Espero que a colaboração continue por muito tempo. Igualmente agradeço a seus estagiários, Ademir, Matheus, Fabiano e Andréia e especialmente à Enara Teixeira, pela quantificação do material lítico e cerâmico;

- ao Professor e mestre Francisco Fajardo, pelos ensinamentos não-acadêmicos compartilhados em sua casa;

- ao Professor Doutor José Alberione dos Reis, pelo auxílio bibliográfico e sugestões;

- ao Professor Doutor Pedro Paulo Funari, pelas conversas informais e correspondências sempre gentis;

- ao Professor Francisco Noelli, pela iniciação no mundo acadêmico, sem o qual seria impossível realizar esta tese;

- à minha família, por perdoar minha ausência;

- aos amigos José Eduardo (Dadá), Anselmo Neetzow, Fátima Segatto, Sandra Medina e Silvia Piedade, que mesmo entendendo pouco ou nada de arqueologia Guarani me estimularam cada um a sua maneira;

- à minha noiva, Gertha Corrêa, que tem me ensinado mais do que a academia pode acumular;

- agradeço, enfim, aos mestres da Grande Fraternidade Branca, que me apoiaram e sustentaram nos momentos mais difíceis do trajeto. 


\section{RESUMO}

Este trabalho trata da análise da cultura material de um sítio arqueológico Guarani (sítios RS-JC-56 e RS-JC-57, considerados um único sítio para efeitos desta tese). Para tanto, realizou-se um breve histórico da arqueologia Guarani no Estado do Rio Grande do Sul, Brasil. Abordou-se os remanescentes arqueológicos através dos conceitos de testemunhos, termo utilizado por André LeroiGourhan nas escavações do sítio de Pincevent, França, na década de 1960. Apresentou-se a escavação do sítio, os procedimentos utilizados para a classificação das áreas escavadas em área de habitação e área de descarte. A partir da análise dos diferentes testemunhos, realizou-se considerações sobre o uso e função dos artefatos estudados. Também foram apresentadas a cronologia do sítio e uma breve discussão sobre as técnicas utilizadas, com base em mais de vinte e cinco datações realizadas. Apresentaram-se, ainda, algumas interpretações sobre o uso do espaço a partir da distribuição dos testemunhos.

\section{Abstract}

This paper is about the analysis of the material culture of an archeological Guarani site (sites RS-JC-56 and RS-JC-57, considered a single site for effects of this thesis). Therefore, a historical abbreviation of the archeology Guarani in the State of Rio Grande do Sul in Brazil took place. The archeological remainders were studied and approached through the concepts of testimonies, term used by André Leroi-Gourhan in the excavations of the site of Pincevent, France, at the 1960's decade. This thesis came from the excavation of the site and the procedures used for the classification of the areas dug in house area and scratch pad. Starting from the analysis of the different testimonies, considerations about the use and function of the studied workmanships took place. Also the chronology of the site and an abbreviation discussion about the used techniques based in more than twenty-five accomplished datings were presented. They came, still, some interpretations on the use of the space starting from the distribution of the testimonies.

Palavras-chave: Arqueologia, Guarani, Pré-história do RS, análise intra-sítio 
SUMÁRIO

Dedicat oria

Resumo $\quad 05$

Abstract $\quad 05$

Sumário

Introdução $\quad 08$

1 Revisão da Arqueologia Guarani.............................................................................................. 19

1.1 A arqueologia da tradição Tupiguarani 19

1.2 A arqueologia da subtradição Guarani 24

1.3 Por uma arqueologia Guarani 28

20 sítio RS-JC-57 (Wilmoth Röpke): breve introdução .................................................... 36

2.1 A localização do sítio na paisagem 37

2.1.1 Metodologia aplicada para localização e escavação do sítio 37

2.1.2 Escavação do sítio $\quad 39$

2.1.3 Contextualização estratigráfica 44

$2.2 \mathrm{O}$ que foi considerado artefato: sedimentos, lítico, cerâmica, ossos, conchas, 48 evidências negativas

2.2.1 Testemunhos brutos $\quad 50$

2.2.2 Testemunhos modificados

2.2.3 Testemunhos manufaturados $\quad 53$

$\begin{array}{ll}2.2 .4 \text { Testemunhos fugazes } & 74\end{array}$

2.2.5 Testemunhos discretos $\quad 81$

$\begin{array}{lr}2.2 .6 \text { testemunhos negativos } & 82\end{array}$

3 Datações obtidas para o sítio ..................................................................................... 84

3.1 Breve histórico das datações em sítios Guaranis $\quad 84$

3.2 As datações obtidas pelo LACIFID 91

3.3 Outras datações obtidas 96

3.4 Datações por $\mathrm{C}_{14}$

4. Determinando o uso do espaço: análise dos artefatos e sua distribuição no sítio $\quad 100$

$\begin{array}{ll}4.1 \text { Testemunhos brutos - distribuição } & 101\end{array}$

4.2 Testemunhos modificados- distribuição 102

4.3 Testemunhos manufaturados - distribuição 103

$\begin{array}{ll}\text { 4.3.1 Material lítico: arenito } & 103\end{array}$

$\begin{array}{ll}\text { 4.3.2 Material lítico: calcedônia } & 105\end{array}$

$\begin{array}{ll}4.3 .3 \text { A cerâmica } & 108\end{array}$

4.4 Testemunhos fugazes 117

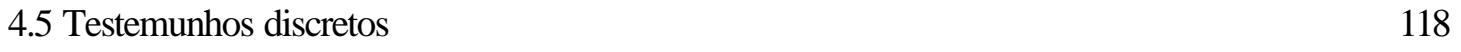

4.6 testemunhos negativos $\quad 119$

Considerações Finais .............................................................................................. 122

Referências Bibliográficas .................................................................................. 130

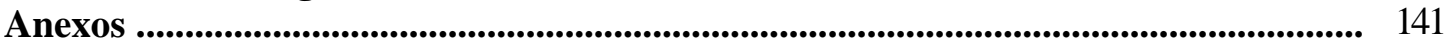

Anexo 1: Desenhos 141 
Anexo 2: Fotos da escavação 148

Anexo 3: Fotos dos artefatos 157

Anexo 4: Gráficos de distribuição de artefatos $\quad 178$

Anexo 5: Tabelas de análises de solo 227

Anexo 6: Tabela com quantificação cerâmica 232

Anexo 7: Datações 234

\section{LISTA DE TABELAS}

Tabela 1: Quadro resumo das análises de solo realizadas pelo Laboratório

Central de análises de Solo, UFSM.

Tabela 2: Resumo dos elementos analisados em digestão total pelo

Embrapa/solos/RJ.

Tabela 3: Concentrações de $\mathrm{C}$ (carbono), $\mathrm{N}$ (nitrogênio) e relação entre $\mathrm{C} / \mathrm{N}$ (carbono nitrogênio) das amostras.

\section{LISTA DE FIGURAS}

Desenho 1: Perfil do local do sítio, com a barranca do sítio a esquerda. O croqui original está publicado em Schmitz, Rogge e Arnt, 2000, p.207, modificado pelo autor.

Relevo do sítio: curvas de nível do sítio RS-JC-57, sítio Wilmuth Röpke. As divisões são de um metro (cem centímetros). Projeção vista sul em direção ao norte.

\section{LISTA DE GRÁFICOS}

Gráfico 1: Bordas de panelas corrugadas considerando diâmetro de boca e número de fragmentos.

Gráfico 2: Bordas de tigelas considerando diâmetro de boca e número de fragmentos.

Gráfico 3: Bordas de tigelas de beber, considerando diâmetro de boca e número de fragmentos.

Gráfico 4: Bordas de pratos de comer, considerando diâmetro de boca e número de fragmentos. 


\section{INTRODUÇÃO ${ }^{1}$}

Um modelo sem correlatos empíricos, desvinculado das características do material a ser estudado, é tão válido para a Arqueologia quanto o modelo que explica a origem da humanidade por via extraterrestre, ou a partir de Adão e Eva. Aceitar o modelo ou não se torna uma questão de fé, visto que não há como julgá-lo face às evidências (ARAÚJO, 2001, p. 57).

Neste trabalho, apresentam-se os resultados da análise do sítio arqueológico RS-JC-56 e RS-JC-57, sítio Wilmuth Röpke, usualmente tratados como pertencentes à tradição Tupiguarani, ou subtradição Guarani. Trata-se, na verdade, da ocupação de dois espaços distintos por duas sociedades temporalmente distintas, mas produzindo artefatos semelhantes, que se denomina antepassados das sociedades indígenas Guaranis. ${ }^{2}$

As propostas que orientaram este trabalho partiram da premissa que poucos sítios Guaranis no Rio Grande do Sul foram escavados em áreas amplas, sendo essa uma das contribuições desta tese. Ao mesmo tempo, a arqueologia Guarani no Estado do Rio Grande do Sul passou por uma grande influência do Programa Nacional de Pesquisas Arqueológicas (PRONAPA), decorrendo daí que os trabalhos na arqueologia gaúcha até os anos 1990 primassem, sobretudo, pela descrição dos artefatos, com pouca ênfase à interpretação deles. A criação de fases, ou o enquadramento do material em fases pré-existentes norteou a pesquisa sobre a tradição Tupiguarani durante toda a vigência do PRONAPA e ainda depois de seu término.

Desde o início desta pesquisa deixa-se claro que a abordagem visa a uma análise destituída de aportes históricos e etnográficos, de forma que se propõe uma interpretação em que os testemunhos materiais sejam o principal foco das análises, observados em seu espaço, no qual a interdisciplinaridade foi estreitada com as ciências da terra, ao invés das ciências humanas. Desde já se coloca que esta foi a opção, acrescentando que, em futuro próximo, pretende-se contemplar as fontes históricas e etnográficas aqui deixadas de lado.

Apresentam-se, aqui, os resultados obtidos neste trabalho e a contribuição que este oferece à pesquisa de sítios arqueológicos Guaranis a partir deste estudo de caso. Neste sentido, essa abordagem pode ser expandida a qualquer sítio Guarani da bacia do rio da Prata

\footnotetext{
${ }^{1}$ Neste trabalho utilizou-se como referência para as normas técnicas as orientações da ABNT 2000, 2002a e $2002 b$.

${ }^{2}$ Há uma discussão sobre o tratamento a ser dado a estas sociedades. Enquanto uma proposta históricoculturalista adota o termo tradição Tupiguarani, com ou sem variações (Subtradição Guarani, ver crítica em SCHIAVETTO, 2003), preferiu-se adotar o termo Arqueologia Guarani. Uma outra proposta (SILVA, 2002) é a utilização do termo Proto-Guarani para referir-se às sociedades proto-históricas e arqueológicas.
} 
e Brasil Meridional, dadas as semelhanças existentes entre a cultura material deste sítio com diversos outros, principalmente nos aspectos mais conhecidos que são os testemunhos manufaturados, especificamente, a cerâmica e o lítico.

Por outro lado, o resgate das especificidades deste sítio é fundamental para que sua importância não seja subestimada. Em primeiro lugar, o sítio RS-JC-57 encontrava-se em um dos locais mais bem estudados no Estado do Rio Grande do Sul. Em contrapartida, não há, com exceção do sítio Candelária, publicado por Schmitz et al. (1990) e o trabalho de Carle (2002), publicações sobre habitações em sítios Guaranis escavados com inserção planialtimétrica. Neste estudo de caso, a metodologia aplicada permitiu definir suas estruturas e foram resgatados, com certa sistemática, os artefatos utilizados/descartados desta mesma ocupação. A abordagem sobre os diferentes materiais ressalta a importância das técnicas de resgate e documentação, uma vez que diversos testemunhos são compostos por vestígios que não podem ser "armazenados" no laboratório, demonstrando que o registro acurado é fundamental nos processos destrutivos levados a cabo pela escavação.

Em segundo lugar, a pesquisa foi realizada em um local sem perturbações contemporâneas, o que leva a acreditar que o sítio pesquisado seja um dos poucos em que o estado de conservação fosse bastante satisfatório, salvaguardadas as perturbações pósdeposicionais descritas em Milder (2000).

Em terceiro lugar, o vale do rio Jacuí e, em especial, a área do médio vale deste rio, é a que apresenta datações mais antigas para o Estado e, quiçá, para a arqueologia Guarani como um todo. Embora o conjunto de datações publicadas em Brochado (1984) possa ser questionado, conforme apresentado nos capítulos primeiro e terceiro desta tese, ainda assim trata-se de uma região com ocupação Guarani bastante recuada. Além disso, esta pesquisa buscou avançar não só sobre a abordagem de análise, mas também sobre a polêmica suscitada pela divulgação de datas com mais de três mil anos para a ocupação Guarani no local.

Considerando a análise dos testemunhos arrolados, acredita-se que esta pesquisa conseguiu contribuir com a arqueologia Guarani, pela proposta de uso do espaço doméstico e pela distribuição espacial dos testemunhos que compõem uma habitação pré-colonial.

Realizou-se uma abordagem estritamente baseada nos artefatos pelos seguintes fatores:

- limitado número de trabalhos que apresentam escavações em superfícies amplas no Estado do Rio Grande do Sul;

- tentar ultrapassar a fase descritiva da arqueologia Guarani, propondo interpretações às estruturas escavadas. 
Esta abordagem pode também ser considerada "etnológica", nos termos propostos por Leroi-Gourhan e Brézillon (1966, p. 323), ${ }^{3}$ na qual os testemunhos foram classificados considerando os materiais do sítio em questão.

Os objetivos desta tese, portanto, são:

1) Realizar uma análise da cultura material, buscando demonstrar as vantagens das técnicas utilizadas na recuperação dos vestígios materiais;

2) Contribuir para o conhecimento dos artefatos produzidos e/ou utilizados pelos Guaranis no período anterior ao contato com europeu;

3) Situar cronologicamente a ocupação do sítio RS-JC-57 e discutir a validade das datas e os métodos utilizados para realizar cronologias culturais;

4) Analisar as relações espaciais da distribuição dos testemunhos no interior do local considerado habitação.

Esta tese está organizada em quatro capítulos. O primeiro capítulo contextualiza a arqueologia Guarani no Estado o Rio Grande do Sul desde sıa maior expansão, no período do PRONAPA. As propostas inovadoras apresentadas por Brochado (1984), consolidadas a partir de sua tese, e algumas de suas idéias que ainda não foram aprofundadas; uma proposta de ampliar o estudo sobre a especificidade das sociedades arqueológicas Guarani, com maior discernimento a respeito das diferenças existentes na cultura material, que aponta para as distintas parcialidades historicamente conhecidas.

O segundo capítulo trata dos sítios RS-JC-56 e RS-JC-57, localizados, prospectados e escavados por Ribeiro e outros na década de 1980 que, nesta tese, estão sendo considerados apenas um sítio com duas funcionalidades diferentes; das técnicas utilizadas para localização, escavação e registro dos testemunhos; dos elementos que foram considerados testemunhos e das vantagens para esta classificação distinta da classificação segundo a matéria-prima.

O capítulo três apresenta um histórico das datações realizadas e as reações às datas mais antigas, a aceitação e rejeição das cronologias, a utilização da termoluminescência (TL) para a cerâmica Guarani e os resultados obtidos em laboratórios diferentes que utilizam o mesmo método; as cronologias obtidas através do carbono radioativo e as limitações deste

\footnotetext{
3 "la presentation ethonologique de l'habitation 1 de Pincevent est essentiellement fondée sur la nature et la position des matériaux. La détermination de la nature dês témoins aboutit à un classement par grandes catégories" (a representação etnológica da habitação 1 de Pincevent é essencialmente fundada sobre a natureza e a posição dos materiais. A determinação da natureza dos testemunhos leva a uma classificação por grandes categorias). Todas as traduções foram realizadas de forma livre, para a compreensão do público. As citações originais foram colocadas no texto ou em nota de rodapé, conforme o caso.
} 
método; a discussão a respeito da validade das datas obtidas e o marco temporal aceito como válido para o sítio.

O capítulo quatro trata da distribuição espacial dos testemunhos e das análises e as interpretações possíveis de serem realizadas a partir desses; da análise da dispersão do material, suas possíveis causas e as interpretações realizadas; das inferências sobre demografia e forma de distribuição das pessoas através da análise dos testemunhos.

\section{Bases teóricas e metodológicas}

What guides or focuses our studies? We might add that since archaeology is the science of the archaeological record, one would expect that the problems we seek to solve are derived from a study of archaeological remains (BINFORD, 2001, p.669). ${ }^{4}$

Acredita-se que a pesquisa arqueológica, tal como descrito na epígrafe acima, estuda os vestígios arqueológicos tratados, neste trabalho, como testemunhos da cultura material. Desta forma, o ponto de partida foram os diferentes testemunhos ${ }^{5}$ distribuídos no espaço escavado, suas relações entre si e com outras evidências.

A pot without provenance is of limited value to archaeological interpretation. It has long been recognised that placing things in context is fundamental to understanding the past. Much of conventional archaeological technique is about establishing empirically rich contexts of things (SHANKS $e$ HODDER, 1995, p.14). ${ }^{6}$

Como afirma Binford (2001, p. 672), a arqueologia não precisa buscar recursos em teorias de outras ciências ou disciplinas para o fazer arqueológico. Para interpretar os vestígios e artefatos, da melhor forma possível, deve-se expor os conceitos e definições utilizados. Desde já, esclarece-se que foi utilizada mais de uma abordagem teórica neste trabalho.

Este é um estudo de caso que procura analisar a distribuição dos testemunhos em uma visão sincrônica, ou seja, a preocupação foi compreender a forma ou o uso que o espaço teria no momento imediatamente anterior ao seu abandono. Uma vez que se está tratando sobre a

\footnotetext{
4 "O que guia ou foca nossos estudos? Nós devemos acrescentar que desde que a arqueologia é a ciência do registro arqueológico, espera-se que os problemas que procuramos resolver são derivados do estudo dos remanescentes arqueológicos."

${ }^{5}$ As definições de "testemunho" utilizadas nesta tese estão explicadas no capítulo 2, item 2.2.

6 "Um pote sem proveniência é de valor limitado para interpretação arqueológica. Tem sido reconhecido que coisas colocadas no contexto é fundamental para compreender o passado. Muito da técnica arqueológica convencional é sobre estabelecer empiricamente contextos ricos de coisas”.
} 
análise do espaço de uma habitação, buscou-se compreender tão somente o interior desta estrutura, sem a preocupação das relações entre a sociedade e o meio, bem com não interessou as formas de exploração/manuseio do ambiente. ${ }^{7}$

Sendo assim, uma forma de iniciar a apreciação sobre a análise realizada parte das definições e conceitos utilizados nesta tese. Uma das primeiras definições a serem discutidas diz respeito ao entendimento sobre sítio arqueológico. Segundo Dias (1995): ${ }^{8}$

Em 1958, Willey e Phillips definiram sítio como a mais pequena unidade de espaço tocada pela mão dos arqueólogos podendo esta ir do acampamento efêmero à grande cidade. Por sua vez, em 1967, Deetz definiu 'sítio' como o local onde se encontrava antes outra coisa, onde o arqueólogo explora e investiga. Para Deetz, é a possibilidade de investigar que é determinante para a definição de sítio arqueológico. Quatro anos mais tarde, Plog e Hill consideraram ser 'sítio arqueológico' toda a localização de objetos culturais mesmo que se tratasse de um sílex. A definição destes dois autores, colocou o problema da diferenciação entre descoberta isolada e o sítio. Esta espécie de fronteira ainda hoje nos parece difícil de definir . Em 1980, Mazurowski acrescentou às anteriores definições, a importância que tem a localização dos objectos por se poder teoricamente discernir através desta, o carácter intencional ou não dos achados. Para este autor, o carácter intencional dos objectos seria a chave milagrosa para a definição de 'sítio arqueológico'. Esta intencionalidade também não nos parece ser ainda hoje facilmente medida. Perante tal multiplicidade de definições, não consideramos de forma alguma contraditório afirmar não existir uma única definição de 'sítio arqueológico', pois todas elas nos parecem aceitáveis (DIAS, 1995).

Uma síntese destas definições é estabelecida por Morais (1999, p.11): "sítio arqueológico é a menor unidade do espaço passível de investigação, dotada de objetos intencionalmente produzidos ou rearranjados, que testemunham as ações de sociedades do passado". Desta forma, um sítio arqueológico Guarani é o local no qual as atividades desenvolvidas e os testemunhos presentes distribuídos no espaço permitem associar ambos (atividades e/ou testemunhos) a determinadas propriedades. Neste caso, as propriedades vão além do "fóssil-guia" ou "artefato típico", e compartilha-se o conceito de Morais (1999, p. 101 et seq.) no qual a caracterização de um assentamento deve partilhar alguns atributos comuns:

\footnotetext{
${ }_{8}^{7}$ Este trabalho está sendo desenvolvido por Sérgio Klamt, em sua tese de doutoramento.

8 Conforme apresentado por Dias, Vítor. Prospecção e Conceito de Sítio, Cyberarqueólogo Português, $<$ http//www.ci.uc.pt/aia/sitio.html>, junho 1995, último acesso em 12/04/04.

${ }^{9}$ Fósseis-guias são os tipos morfológicos que servem de baliza para a classificação dos artefatos. Também são denominados 'artefatos típicos'. No caso da arqueologia Guarani, a tradição Tupiguarani era "caracterizada principalmente por cerâmica policrômica (vermelho e ou preto sobre engobo branco e ou vermelho), corrugada e escovada" (Terminologia, 1976, p. 146).
} 
- Vestígios representados por testemunhos líticos e cerâmicos.

- Distribuição dos vestígios segundo planos espaciais com zonas diferenciadas, representadas por manchas escuras, quase negras.

- Localização dos conjuntos escuros em áreas de ápice de colinas com declives suaves.

- Existente constante de um rio na base da colina.

- Fitogeografia regional representada peb cerrado, manchas de floresta tropical e palmeiras sobre solos latossólicos avermelhados.

- Conceituação geral dos sítios como sendo correspondentes a aldeias pré históricas situadas em colinas próximas a rios, cujos habitantes eram ceramistas embora conservando ainda a técnica de trabalho em pedra (MORAIS, 1999, p. 101).

No caso da ocupação Guarani meridional, como será visto no capítulo 1, os itens 3, 4 e 5 apresentam-se de forma diferenciada, pois não há ambiente, clima ou altitude preferencial para a ocupação Guarani (ver padrão de assentamento Guarani em Brochado (1975, p. 110 et seq.; também o capítulo 1 desta tese).

Retornando às definições necessárias para o desenvolvimento desta tese, um dos conceitos fundamentais para esclarecer a compreensão apresentada da arqueologia Guarani é estrutura. Uma vez que foi proposto analisar várias estruturas, entre elas, a de habitação e descarte, faz-se mister esclarecer que se trata de uma estrutura arqueológica. Segundo LeroiGourhan (1972, p. 325), em seu vocabulário, estrutura é:

la trame des rapports unissant différents témoins qui constituient un groupement significatif. La pertinence du groupement est fondée sur la rèpètition de situations analogues (...) sur la liaison entre les éléments d'un même témoin (déchets de débitage pouvant conduire au remontage d'un nucleus). A Structure évidente : groupe de témoins dont la struture est directement perceptible (foyer, amas de débitage....). ${ }^{10}$

Neste mesmo componente de análise, é importante salientar que são estruturas de habitação e área de descarte:

Habitation (unité d'): ensemble comportant les élements domestiques et les strutures d'évacuation ou les annexes. Espace domestique: surface délimitant la partie construite de l'habitation. Est composé du foyer, de l'espace d'activité et de

\footnotetext{
10 “A trama das relações unindo diferentes testemunhos que constituem um grupamento significativo. A pertinência do grupamento é fundada sobre a repetição de situações análogas. (...) sobre a ligação entre os elementos de um mesmo testemunho (dejetos de debitagem podem conduzir a remontagem dos núcleos). A Estrutura evidente: grupo de testemunhos que a estrutura é diretamente perceptível (fogão, concentração de debitagem)".
} 
l'espace réservé. (...) Espace d'évacuation: correspond aux surfaces occupées par les déchets de fabrication et d'évacuation domestique (idem, p. 326). ${ }^{11}$

No caso das estruturas de habitação observadas em campo, Brochado (1975, p.112) observa que "de manera general se admite que los núcleos de concentración de fragmentos de cerámica representan los sitios de las habitaciones. Los tiestos habrían sido arrojados adentro o cerca de las habitaciones", o que redundou na associação mancha preta = habitação (ver discussão no item 1 do capítulo 1).

A questão da disposição e arranjo dos testemunhos é fundamental para a compreensão do sítio arqueológico e as atividades que nele se desenrolaram. Assim, somente a partir da compreensão no espaço pode-se tratar de um sítio (ou assentamento). Na definição de Chang (1976, p. 27):

Un asentamiento no es una abstracción lógica, ni puede caracterizarse mediante una lista - por muy elaborada que sea- de tipos de artefactos. Señala una realidad empírica, una unidad física de deposición compuesta de cosas culturales abandonadas con determinadas relaciones espaciales.

Assim, a definição de assentamento representaria o equivalente arqueológico de uma comunidade $^{12}$ (CHANG, 1976, p.101), estendendo em uma escala temporal limitada (ibid. p. 50). No entanto, não se pode tomar o conceito de assentamento de uma definição antropológica, buscando grupos sociais em culturas arqueológicas. Mesmo que para Chang a arqueologia seja percebida como parte da antropologia, no sentido de que a interpretação arqueológica é operacional a partir das analogias que a antropologia oferta, não se pode tomar emprestado as definições utilizadas de outras disciplinas:

La comunidad consiste esencialmente en un agregado de gentes que actúan y se interrelacionan, pero el asentamiento arqueológico en una unidad empírica definida en el tiempo y en el espacio y con la forma significativa de un estado estacionario (CHANG, 1976, p.102).

Assim, deve-se esclarecer quais os problemas que orientaram esta pesquisa, isto é, quais perguntas se queria responder. A questão básica era: como, através da cultura material,

\footnotetext{
11 “Habitação (unidade de): conjunto comportando os elementos domésticos e as estruturas de evacuação ou os anexos. Espaço doméstico: superfície delimitando a parte construída da habitação. É composta do fogão, do espaço de atividades e do espaço reservado (...) Espaço de evacuação: corresponde às superfícies ocupadas pelos dejetos de fabricação e evacuação doméstica".

${ }_{12}$ "Una institución o un sistema social básicos; una clave para la sociedad; y un modelo, quizá el más importante, del a cultura (...). De este modo, la comunidad establece las pautas en las relaciones y actividades de aquel grupo humano, e incluso las que se refieren al tiempo y al espacio" (ARRENSBERG e KIMBAL, 1965, apud CHANG, 1976, p. 101).
} 
pode-se interpretar ou inferir os usos do espaço dentro de uma habitação? Embora aparentemente haja uma contradição na utilização nos termos cultura material, segundo o modelo cartesiano de pensamento - uma vez que o termo cultura refere-se ao abstrato e o termo material refere-se ao concreto - acredita-se que a análise dos testemunhos apresenta um acréscimo de interpretações sobre o uso social do espaço intra-sítio deste estudo de caso:

Se aceitarmos que o social é um campo de relacionamentos antes do que uma entidade limitada, penso que se torne mais fácil reconhecer o caráter inerentemente social da cultura material. (...) Então, o efeito dessa visão é remover a 'sociedade' dessa proeminente posição como um objeto de análise substituindo-a pelo 'social', que é um espaço ou campo ilimitado. Como resultado, esta preocupação com a prática gera um movimento de um foco sobre entidades para um foco sobre relações (THOMAS, 1999, p. 17).

Desta forma, a pergunta estava direcionada ao uso e função das estruturas escavadas, posteriormente designadas "área de habitação" e "área de descarte", bem como a distribuição dos testemunhos nestes espaços. A interpretação da funcionalidade dos espaços e dos testemunhos arrolados tentou, sempre que possível, afastar-se da analogia etnográfica, na compreensão que se poderia fazer uma análise "dura" dos objetos e do local onde se encontravam. Sabe-se que o abandono dos dados etno-históricos conduziria este trabalho a um “esforço criativo". Nas palavras de Shanks e Hodder (1995, p. 11):

Archaeological interpretation requires that some things be connected with other in order to make sense of what remains of the past. Circular features in earth of contrasting colour are associated with removed wooden stakes, and then in turn associated with other post-holes to trace the structural members of a building. To interpret is in this way a creative act. Putting things together and so creating sense, meaning or knowledge. ${ }^{13}$

Ao mesmo tempo, para interpretar os dados empíricos, a precisão das técnicas seria uma das chaves para uma bem-sucedida interpretação dos vestígios que, em alguns casos, jamais poderiam ser reanalisados, como no caso dos testemunhos negativos, por exemplo. Embora se esteja explicitamente abrindo mão do uso das fontes históricas e etnográficas, é impossível negar que, por outro lado, a formação de historiador influenciou e determinou, às vezes, o tipo de interpretação e análise predominante. No entanto, isto não chega a ser

\footnotetext{
13 "Interpretação arqueológica requer que algumas coisas sejam conectadas com outras em ordem para fazer sentido de quais restos do passado. Traços circulares na terra de cor contrastante são associadas com estacas de madeira removidas e, por sua vez, associadas com outros buracos de postes para traçar os membros estruturais da construção. Interpretar é, desta forma, um ato criativo. Colocar coisas juntas e assim um criar sentido, significado ou conhecimento."
} 
contraditório, pois ao mesmo tempo em que se busca uma descrição acurada da distribuição espacial, deter-se exclusivamente em uma listagem de atributos do material em nada acrescentaria à pesquisa arqueológica Guarani, e como esta tem sido levada a cabo.

Assim, a tarefa do arqueólogo torna-se dupla: tentar identificar, através da crítica da concepção moderna, dentro da qual os testemunhos jazem, e 'reanimar' esses testemunhos através da interpretação. A interpretação é uma tentativa de retrabalhar relacionamentos passados, recolocando peso nos fragmentos materiais do passado. Necessariamente, o que se tem no fim é uma leitura do passado, que é do e para o presente, mas penso que seja também fundamentada e delimitada pelos testemunhos materiais (THOMAS, 1999, p. 18).

No entanto, sabe-se que existem diversas limitações para a interpretação do arranjo espacial dos objetos e a compreensão dos processos pós-deposicionais que atuaram no sítio (como a argiloturbação, a ação dos animais fossadores, a ação das raízes e outros, ver MILDER, 2000). Se, por um lado, não se pode incorrer na ingenuidade de atribuir às perturbações uma parcela de "destruição" do sítio que impossibilita seu estudo, caindo nas "armadilhas do senso comum" 14 em relação ao potencial de cada unidade de escavação, por outro tem-se consciência que o processo de leitura do registro arqueológico é, de alguma forma, uma “invenção", da mesma maneira que toda reconstrução do passado também o é:

We are concerned to emphasise that the person of the archaeologist is essential in coming to understand the past. The past is not simply under the ground waiting to be discovered. It will not simply appear, of course, but requires work. Consider discovery. Discovery is invention. The archaeologis uncovers or discovers something, coming upon it. An inventor may be conceived to have come upon a discovery (SHANKS e HODDER, 1995, p.11). ${ }^{15}$

É neste sentido que se considera a contribuição da Hermenêutica para a Arqueologia (JOHNSEN e OLSEN, 1992, p. 419-436), ${ }^{16}$ uma vez que existe uma série de perdas e ganhos na constituição/formação do sítio até a ação do arqueólogo (ARAÚJO, 1999, 2001). Assim, a "invenção", citada acima, é resultado da dinâmica de diversos fatores, como geológico e ambiental, por parte do meio, e social e cultural, por parte do arqueólogo que sobre o sítio atua (na escavação e/ou interpretação). Por este motivo, esta "invenção" que se está propondo deve

\footnotetext{
14 Referência ao trabalho de Araújo (2001-2002), 'Destruído pelo arado? Arqueologia de superfície e as armadilhas do senso comum', Revista de Arqueologia, p. 14-15.

15 "Nós estamos interessados em enfatizar que a pessoa do arqueólogo é essencial para compreender o passado. O passado não está simples mente sob o chão esperando para ser descoberto. Ele não aparecerá, por certo, mas requer trabalho. Considerar descoberta. Descoberta é invenção. O arqueólogo cobre ou descobre alguma coisa, traz à tona. Um inventor pode ter concebido ter realizado uma descoberta."

${ }^{16}$ Hermenêutica aqui é "concebida como manifestações textuais compreendidas ou interpretadas sem a imediata presença das ou acesso às sociedades da qual os textos originam” (op.cit. p.423).
} 
ser resguardada, ao máximo, pelo registro arqueológico, uma vez que esta sociedade, ainda que presente até os dias de hoje, certamente não é a mesma do passado (SHANKS e HODDER, 1995, p.12).

A pretensão deste trabalho é realizar uma pesquisa básica. Nas palavras de Yoffe (1996, p. 123):

O primeiro nível das teorias operativas que guiam diariamente as atividades arqueológicas de recuperar, identificar e classificar os materiais arqueológicos. Estas atividades - incluindo estratigrafia, datação, estudos cerâmicos, processos formativos e muito mais - são as que a maior parte dos arqueólogos executam a maior parte do tempo. Muitas destas atividades, nos quais os arqueólogos têm extremo sucesso, podem ser chamadas de metodologia, mas para não roçar a sensibilidade de alguns arqueólogos, chamo este nível de 'teoria de nível básico'. Os ingredientes da 'teoria de baixo nível' sustentam os arqueólogos e a combinação destes - usando princípios de geologia, física, química, botânica e lingüística, entre outras - dá à arqueologia sua base científica e a transforma numa atividade multidisciplinar.

Sendo assim, apresenta-se um trabalho em que os procedimentos de recuperação, identificação e classificação do material escavado têm importância fundamental para as interpretações realizadas. Por outro lado, não se concorda com a criação de uma "nova teoria sócio-evolucionista", como proposta por Yoffe (1996) sem comprovação possível no registro arqueológico (cf. crítica em ARAÚJO, 2001, p.56). Também se compartilha a idéia de que qualquer abordagem requer uma posição teórica, pois não há escavação ou projeto de pesquisa sem um problema a ser resolvido e um caminho a ser seguido para respondê-lo.

Ao mesmo tempo, esta análise limita-se ao espaço intra-sítio, delimitando, ainda que timidamente, o uso social dos espaços internos da habitação escavada. Em trabalhos futuros, pretende-se analisar outras habitações para que se possa aplicar o modelo sugerido por Soares (1997), buscando a fundamentação empírica para os modelos sociais para interpretação arqueológica de grandes áreas.

A limitação encontrada em trabalhos anteriores (SOARES, 1996, 1997, 1998) foi por considerar a sociedade Guarani como uma organização complexa ao longo de toda sua existência até o encontro com a sociedade ibérica. Neste sentido, a complexidade política e econômica atribuída aos Guaranis no período pré-contato podem não ter sido uma constante, ou ser restrita a um hipotético "apogeu" que teria ocorrido justamente no momento em que os colonizadores europeus se avizinharam. 
Esta tampouco é uma idéia nova. Brochado, em sua 'síntese genial, ${ }^{17}$ já demonstrava a complexificação da tradição policrômica amazônica desde sua formação (BROCHADO, 1984). Em trabalho anterior, ainda baseado nos modelos interpretativos do PRONAPA, Brochado (1975) acenava com a idéia de que a expansão máxima dos Guaranis seria concomitante ao período de conquista, em escala crescente de complexidade. Em outros lugares, foi possível observar sociedades de estruturas políticas complexas, como os cacicados do sudeste dos EUA, que passaram por um processo de "regressão" em sua organização sociopolítica, ainda no período pré-contato, de forma que os grupos atuais não reproduzem as formas organizacionais a ponto de permitir o uso da analogia etnográfica (YOFFE, 1996).

Sendo assim, acredita-se que somente com um conjunto de datações válidas e coerentes, associado a áreas amplas escavadas, poder-se-ia especular sobre a organização social e política de uma sociedade em suas relações inter-tribais. As informações da cultura material que respaldem estas idéias ainda estão em sua fase embrionária, de forma que, neste trabalho, busca-se inferir as relações de um espaço doméstico, uma vez que o material escavado permite deduzir as atividades ocorridas em uma habitação.

Acredita-se que novas interpretações a respeito do material e do uso do espaço habitacional podem ser efetuadas. As análises desenvolvidas limitaram-se à distribuição dos testemunhos e de breves relações que são possíveis de serem observadas entre os distintos testemunhos. Neste sentido, grande parte da "teoria" desta tese está em construção, à medida que será elaborada a partir do surgimento de novos dados e nas diferentes abordagens e interpretações ainda não realizadas, pois, conforme Binford (2001, p. 676):

theory is not something one brings to data. Theory is developed to explain relational patterns among data that are analytically generated among different observational domains or data sets. (...) This means that archaeologist should develop their research problems through analytical study of the archaeological record. ${ }^{18}$

Parafraseando Paul Bahn (1993, p. 63), “teoria é uma série de hipóteses" e, sendo assim, algumas perguntas suscitaram respostas que poderiam ser respondidas de forma diferente. Esta abordagem é uma entre várias possíveis, a partir dos instrumentos que estavam disponíveis.

\footnotetext{
${ }^{17}$ Funari; Neves e Podgorny (1999, p. 1).

18 “Teoria não é algo que se traz aos dados. Teoria é desenvolvida para explanar padrões relacionais entre dados que são analiticamente gerados entre diferentes domínios observacionais ou conjunto de dados (...). Isto significa que arqueólogos deveriam desenvolver seus problemas de pesquisa através de estudos analíticos do registro arqueológico".
} 


\section{REVISÃO DA ARQUEOLOGIA GUARANI}

Neste capítulo, realizar-se-á uma breve revisão dos pressupostos que nortearam a produção científica sobre a arqueologia dos grupos considerados antepassados dos índios falantes da língua Guarani, da família lingüística Tupi-Guarani, do tronco lingüístico Tupi. Sendo assim, o desenvolvimento desta arqueologia é apresentado somente a partir do momento de sua maior expansão, ou seja, durante a instalação do Programa Nacional de Pesquisas Arqueológicas (PRONAPA), resgatando as apreciações ao modelo realizado por Brochado (1984) e alunos (DIAS, 1994; NOELLI, 1993; SOARES, 1996, 1997, 1999). Também se analisou o modelo de Brochado, construído sobre bases linguíísticas e históricas, mas que atualmente deve ser revisto frente a ampliação dos dados oriundos de novas escavações e datações calibradas. Propõe-se ainda uma ampliação conceitual na classificação da Subtradição Guarani proposta por Brochado, no entendimento de que o conceito históricoculturalista de “tradição" não pode ser aplicado ao caso Guarani, como será visto adiante.

Além disso, discutiram-se quais os elementos podem nos auxiliar a definir uma proposta de arqueologia Guarani que contemple os dados existentes e, ainda assim, permita expandir o leque de elementos materiais que caracterizam as múltiplas expressões desta sociedade, como as parcialidades.

\subsection{A arqueologia da tradição Tupiguarani}

Embora já existisse, no País, o desenvolvimento de uma arqueologia espontânea quando da implantação do PRONAPA, a necessidade de uma sistematização e uma cronologia para os grupos humanos pré-cabralinos era de vital importância para a continuidade de uma ciência que era realizada de forma restrita a poucos exploradores e interessados. A influência dos pressupostos teóricos do PRONAPA fica evidente se considerado que $95 \%$ das

publicações entre 1960 e 1992 contém os procedimentos deste programa (NOELLI, 1993, p.1).

No caso Guarani, a contribuição do programa é inegável na justa medida em que a extensão territorial do País carecia de uma atividade sistemática e ordenada, na qual a maior área possível fosse investigada em curto espaço de tempo. Ainda, o referencial cronológico, a partir das datas de carbono $14\left(\mathrm{C}_{14}\right)$ financiadas pelo programa, possibilitava uma visão do todo, frente à imensidão das áreas por prospectar. 
Não cabe aqui realizar uma apologia ao programa, mas salientar alguns elementos desconhecidos ou esquecidos pelos pesquisadores, que se acredita poderem ser resgatados para contribuir ao melhor desenvolvimento da arqueologia no sul do País. Um exemplo da validade do trabalho desenvolvido durante o programa e abandonado por alguns pesquisadores posteriormente, que deve ser esclarecido e discutido nesta tese, é o caso da denominação dos sítios Guaranis a partir da existência das "manchas pretas", como aparecem nas publicações (BROCHADO, 1969, 1970, 1971, 1974; MILLER, 1967, 1969).

A configuração dos sítios considerados pertencentes à tradição Tupiguarani no Rio Grande do Sul praticamente igualava o termo "terra preta" com a ocupação pretérita dos Guaranis. A consagração do termo pelo PRONAPA atendia aos pressupostos do Programa, de uniformização de conceitos e definições ao mesmo tempo em que mantinha a atenção voltada sobre uma parte da cultura material, a cerâmica.

Mas, ao mesmo tempo, observa-se que os locais de assentamento desses grupos não possuíam preferência, ${ }^{1}$ ao contrário do que propunham as fontes históricas (MELIÀ, 1987), mais das vezes salientando as baixas altitudes, a proximidade dos cursos d'água de grande porte ou os vales dos rios. Algumas citações recolhidas nas publicações do PRONAPA são esclarecedoras:

Os sítios desta fase (Maquiné) localizam-se no topo das coxilhas e morros, sendo raro encontrá-los nos patamares da encosta da serra, acima de $600 \mathrm{~m}$ de altitude. Os sítios são de habitação em campo aberto e de dimensões regulares, atingindo, não raro, a $5.000 \mathrm{~m}^{2}$. (...) As manchas de terra escura contam-se de duas a oito por sítio, sendo de forma circular ou elíptica e com dimensões que vão de 4 a $20 \mathrm{~m}$. Dentro dessas manchas freqüentemente são encontradas lentes de carvão próximas entre si. Presume-se que estas manchas sejam o antigo chão das casas, porém não encontramos sinais de estacas (MILLER, 1967, p.21).

Os sítios localizam-se próximo a vertentes, por sobre coxilhas da serra do Alto Uruguai e que outrora estiveram cobertas pela mata (...). São de proporções regulares atingindo até $3000 \mathrm{~m}^{2}$. O terreno do sítio é levemente mais escuro do que o circundante. (...) As manchas de terra preta são em número de 1 a3, menores e menos intensas na cor do que as da fase comandaí (MILLER, 1969, p. 38-39).

Acredita-se que, em razão das limitações momentâneas, poucos pesquisadores buscaram resgatar esta informação para a reconstrução, mesmo hipotética, das aldeias Guaranis no Estado do Rio Grande do Sul. Por outro lado, se o PRONAPA avançou na

\footnotetext{
${ }^{1}$ Ver Soares (2001/2002, p. 97-114). Os sítios Guaranis se apresentam em distintos ambientes, desde a várzea até os divisores de água, em florestas, cerrados e até campos, caracterizando um padrão de assentame nto que não é exclusivo sobre várzeas de rios (ver BROCHADO, 1975, p. 110 passim).
} 
identificação dos solos antropogênicos como evidências de ocupação pretéritas, limitou a abordagem de que cada unidade de "terra preta" seria um sítio habitação, conforme a Terminologia (1976), ao invés de tratar o conjunto de manchas como uma aldeia. Assim, mesmo que durante o Programa os arqueólogos percebessem tratarem-se de aldeias (conforme as publicações do próprio PRONAPA colocadas abaixo), permaneceu a utilização dos termos sítio-habitação e sítio-cemitério, ${ }^{2}$ apesar das evidências:

(Fase Guaraci) Ocupavam o flanco das elevações, numa altura compreendida entre 16 e $20 \mathrm{~m}$ acima do nível do rio. Em frente dos sítios sempre havia corredeiras. As evidências arqueológicas espalhavam-se por áreas entre 25 x $20 \mathrm{~m} \mathrm{e}$ 80 × $70 \mathrm{~m}$, numa profundidade de 10 a $20 \mathrm{~cm}$. Em alguns sítios havia manchas escuras de formato circular, mediam geralmente $10 \mathrm{~m}$ de diâmetro e dispunham-se em círculo, sugerindo as habitações numa aldeia (CHMYZ, 1974, p. 77, grifo nosso).

(Fase Guaratã) $\mathrm{Na}$ maioria dos sítios ainda é possível delimitar áreas nitidamente distintas pela maior acumulação de cacos e/ou coloração mais escura do solo. Estas áreas, em número superior a quarenta, provavelmente indicam os locais onde estiveram as habitações. São circulares, medindo entre 10 e $20 \mathrm{~m}$, raramente $30 \mathrm{~m}$ ou mais de diâmetro; ou elípticas, das quais as mais freqüentes medem aproximadamente $20 \mathrm{~m}$ de comprimento e $10 \mathrm{~m}$ de largura, mas podem ser maiores (ex. $30 \mathrm{~m}$ de comprimento e $20 \mathrm{~m}$ de largura). As casas elípticas são orientadas mais comumente leste-oeste, mais raramente nordeste-sudoeste ou noroeste-sudeste. As habitações encontram-se, na maioria, isoladas ou reunidas em grupos de 2, 4 e 5, alinhadas com orientação leste-oeste; ou em semicírculo; distanciadas uma das outras de 10 a $30 \mathrm{~m}$, mais raramente até $50 \mathrm{~m}$. O conjunto sugere aldeamentos compostos de habitações de planta circular ou elíptica, maiores e mais afastadas do que as da fase Vacacaí (BROCHADO, 1971, p.21, grifo nosso).

Os detalhes apresentados, como o alinhamento das casas, as dimensões e os locais de assentamentos perderam-se na confecção de fases e tradições de critérios duvidosos ${ }^{3}$ e utilidade questionável. Assim, uma sugestão para a arqueologia Guarani meridional é resgatar estas informações, haja vista a multiplicidade de repetições a respeito do número de casas por aldeia e suas dimensões:

(Fase Toropi) Na maioria dos sítios ainda foi possível delimitar áreas alongadas, aproximadamente ovais, também nitidamente distintas pela maior

\footnotetext{
2 Sítio-cemitério: local onde foram encontradas apenas evidências de enterramentos primários ou secundários (TERMINOLOGIA, 1976, p.142). Sítio-habitação: local com vestígios de permanência prolongada (Idem, p.143).

3 "(sobre o alto Uruguai) vimos como as fases foram criadas, tem uma versão que dá uma idéia geral de como se criaram as fases, usando as percentagens, e como é que se começava uma nova fase: se, por exemplo, uma amostra não cabia, o pessoal ia num ano fazia uma fase; se no outro ano naquela mesma área ou noutra que a pessoa fosse ele pegasse uma amostra que não encaixava na mesma fase começava uma nova, isso era um critério." (BROCHADO, comunicação pessoal, 20/10/2001).
} 
acumulação de cacos, escurecimento do solo ou remoção do pedregulho. Estas áreas medem entre 5, 10 e 15 metros de diâmetro aproximado, encontrando-se reunidas em grupos de duas a quatro, alinhadas com orientação leste-oeste, ou nordeste-sudeste e em dois casos em semicírculo voltado para nordeste; distanciadas umas das outras desde apenas $5 \mathrm{~m}$ até 20,30, 50 e mesmo $100 \mathrm{~m}$. No interior dum dos núcleos observou-se vestígios de postes de $20 \mathrm{~cm}$ de diâmetro, alcançando até $40 \mathrm{~cm}$ de profundidade (BROCHADO, 1969, p. 39).

As passagens são inúmeras e até dispensáveis, mas acredita-se que, no futuro, possa-se reconstruir algumas plantas de aldeias a partir destes fragmentos, dispersos em todas as publicações pronapianas; o foco das atividades era outro, limitando assim a extensão das pesquisas. Isto fica claro a partir da metodologia empregada, na qual algumas sondagens e poços-testes de um metro quadrado, ou pouco mais, representariam amostras significativas para a determinação das fases e tradições. A dimensão dos sítios, conforme atesta os relatos, atingia, às vezes, milhares de metros quadrados, o que não serviu para determinar a modificação do método:

(Fase Induá) Apesar dos vestígios cerâmicos se espalharem algumas vezes sobre áreas de até $2.500 \mathrm{~m}^{2}$, na maioria se encontram concentrados sobre áreas bem menores, circulares ou alongadas, também apresentando escurecimento do solo. As manchas circulares medem, umas 5 e outras $30 \mathrm{~m}$ de diâmetro; as alongadas entre 30 e $40 \mathrm{~m}$ de comprimento por 15 de largura e 50 a $60 \mathrm{~m}$ de comprimento por 20 a 25 de largura, orientadas predominantemente em sentido leste-oeste. Encontram-se isoladas ou reunidas duas a duas, distanciadas 25 ou $100 \mathrm{~m}$ entre si. Onde os vestígios de habitações apresentam maiores dimensões, observaram-se fragmentos de argila com impressão de ramos finos, possivelmente restos de parede e coberturas de taipa (BROCHADO, 1969, p.39).

O legado do PRONAPA deve ser apreciado, pois se, por um lado, ainda mantêm-se práticas não adequadas de mera classificação e tipologia, por outro, não se resgataram as informações residuais de suas publicações, que apontam para a existência de aldeias, suas formas, a distribuição das casas e suas dimensões. Neste sentido, este resgate será realizado, em parte, por Brochado em sua tese de doutoramento (1984).

Cabe agora mostrar a fragilidade dos pressupostos teóricos do programa no que concerne à problemática desta pesquisa: a definição do que é, arqueologicamente falando, um sítio Guarani. Aqui, é necessário dizer que, do ponto de vista de reconhecimento e classificação genérica, o termo tradição Tupiguarani (ou, mais tarde, Subtradição Guarani proposto por Brochado) é absolutamente relevante para identificar um conjunto de artefatos similares, que compartilham as mesmas características morfológicas. 
No entanto, deve-se ter o cuidado para não utilizar indiscriminadamente este termo para uma associação direta e inequívoca entre sociedades arqueológicas (com mais de mil anos) e seus descendentes históricos e atuais, ou mesmo inferir etnicidade ou parentesco lingüístico. $\mathrm{O}$ conceito de tradição Tupiguarani pelo programa foi assim descrito:

uma tradição cultural caracterizada principalmente por cerâmica policrômica (vermelho e/ou preto sobre engobo branco e/ou vermelho), corrugada e escovada, por enterramentos secundários em urnas, machados de pedra polida e pelo uso de tembetás (TERMINOLOGIA, 1976, p.146).

Neste sentido, o conceito de tradição em nenhum momento se relacionava com grupos étnicos, mas sim como "grupo de elementos ou técnicas, com persistência cultural" (TERMINOLOGIA, 1976, p.145). Segundo Braidwood (1988, p. 48) "tradições são hábitos de manufatura de artefatos, não culturas, tribos, etc." Assim, diversos elementos foram misturados aleatoriamente, como se as tradições pudessem se expandir, invadir, abandonar ou dominar áreas. Esta confusão foi mais bem percebida entre os grupos sem cerâmica, no qual ainda é corrente autores que se referem aos Umbu ou aos Humaitá como grupos humanos e não como tipos de confecção de artefatos (ver crítica em HILBERT, 2000, p.373-380 e ARAÚJO, 2001, p.10-12).

A divisão da tradição Tupiguarani em subtradições (corrugada, pintada e escovada), além de não contribuir para o esclarecimento da dispersão e da cronologia, em virtude das falhas existentes no processo de determinação de fases, ${ }^{4}$ relacionava distintas manifestações culturais sob um grande guarda-chuva de poucos fósseis-guias, como a existência do tratamento de superfície corrugado, a pintura policrômica e os machados polidos.

Em uma visão que conciliava difusionismo e evolucionismo, os mentores do programa não tinham uma clara proposta teórica, uma vez que o próprio histórico-culturalismo foi ampliado e, muitas vezes, descaracterizado por um empobrecimento dos conceitos propostos por Ford (1962, ver crítica em NOELLI, 1993; DIAS, 1994; SOARES, 1997, p. 32-40).

A simples bifurcação da grande Tradição Ceramista Tupiguarani nas subtradições Tupi e Guarani, como feito por Brochado, seguido por Scatamacchia, levando-se em consideração diferenças na cerâmica, não resolve o problema do reducionismo na Arqueologia Brasileira. Antes, uma grande categoria foi quebrada para formar outras duas, permanecendo o monolitismo do modelo histórico-cultural (OLIVEIRA, 2002, p.114).

\footnotetext{
${ }^{4}$ Ver nota 3.
} 
Não cabe aqui retomar todas as críticas que já foram mencionadas contra o Programa. Mesmo tendo influenciado diferentes gerações de arqueólogos, os métodos de campo e a fragilidade teórica continuaram sendo parâmetro para a prática arqueológica. Além disso, se por um lado o termo "Tradição Tupiguarani” foi substituído no jargão dos arqueólogos, percebe-se que pouco se avançou para superar a definição do que caracteriza os sítios atribuídos aos antepassados dos Guaranis.

\subsection{A arqueologia da Subtradição Guarani}

A partir da inclusão de José Brochado no PRONAPA, no segundo ano de vigência do programa (1966), incluíam-se novos pesquisadores para ampliar a área a ser pesquisada. Em suas publicações, até 1975, Brochado mantém a terminologia, os parâmetros e critérios adotados no programa. Em 1980, ele propõe a mudança das três subtradições (pintada, corrugada e escovada) para utilizar o critério de "distribuição regional da popularidade relativa das técnicas de tratamento de superfície e das formas das vasilhas" (BROCHADO, 1980, p. 50). Com isso, é dado o primeiro passo para uma classificação baseada na distribuição regional e das distintas formas da cerâmica. Utilizando o termo "subtradição da região leste e nordeste", Brochado começa a delinear o que mais tarde chamaria de Subtradição Tupinambá, sobretudo a partir da morfologia das vasilhas, caracterizada pelos "pratos rasos e os alguidares de base plana ou aplanada, usualmente com o perímetro de boca oval ou quadrangulóide... As vasilhas carenadas e com ombros são muito raras" (idem, p.50). Em contrapartida, a subtradição da região sul seria caracterizada por "vasilhas de contorno composto, carenadas, com pescoço e ombro bem marcados, perímetro de boca circular, bordas cambadas reforçadas externamente e bases arredondadas ou cônicas” (ibid., p. 50).

Ainda neste trabalho, Brochado sugere o uso da analogia histórica direta como parâmetro interpretativo para responder a qual grupo étnico pertencia esta cerâmica, e avança em uma área na qual os pronapianos não apresentaram ligação aparente, de atribuir etnicidade à cerâmica. Uma vez que, para Meggers e Evans (1970), a base de análise era o método Ford (1962) - e este se preocupava mais com as mudanças culturais do que as sociedades que a produziram -, não havia interesse e tampouco desejo de atribuir a cerâmica arqueológica a grupos vivos. Em tempos de ditadura militar, esta vinculação se tornava perigosa pois permitiria aos índios a reivindicação do uso e propriedade de terras. Os motivos que levaram a esta conduta podem ser buscados no momento político dos anos 1960, no atrelamento e 
subserviência da pesquisa nacional à americana ou ainda à incipiente arqueologia científica no país (FUNARI, 1999a e b).

É neste trabalho que Brochado une as possibilidades interpretativas da etnografia e da etno-história para compreensão dos sítios arqueológicos Guaranis. Este rompimento acadêmico com Meggers e Evans irá se aprofundar com a antiguidade dos Guaranis no vale do rio Jacuí, com as datas próximas ao ano zero da Era Cristã. Estas datas, além de não serem aceitas por estes pesquisadores norte-americanos, colocava em dúvida o modelo de difusão dos ceramistas a partir das terras altas da América do Sul.

Esta discussão foi rejeitada pelo PRONAPA, disfarçada pela criação de mais de 60 fases na tradição Tupiguarani (SIMÕES, 1972) que, de tão questionadas, abririam espaço para o problema social da interpretação cerâmica. A respeito da contemporaneidade das fases e a regionalidade das mesmas, existe vasta correspondência entre Brochado e Meggers e Evans, com farta comprovação tanto dos erros da seriação como da incongruência entre estas e as datações absolutas. ${ }^{5}$ Talvez por causa de tanta insistência que, mais tarde, Meggers e Evans publicaram A utilização de seqüências cerâmicas seriadas para inferir comportamento social (1985, p.05):

Atualmente acreditamos que fases definidas em termos de sequiência seriada podem ser relacionadas a comunidades autônomas ou semi-autônomas e que as tradições definidas em termos de fases compartilham um conjunto de elementos cerâmicos, provavelmente, representem entidades tribais ou lingüísticas.

Mesmo que não tenham, em nenhum momento, rompido formalmente, Brochado e o casal Cliford e Bety foram se afastando teoricamente, ainda mais após a aproximação do primeiro com Donald Lathrap. As críticas ao modelo do PRONAPA encontrava ressonância no avanço da arqueologia americana através da new archaeology e dos arqueólogos sob influência francesa.

Embora o modelo de Brochado (1984) seja um paradigma para a difusão da cerâmica policrômica no leste da América do Sul, diversas questões têm sido colocadas em xeque a partir do aumento significativo das pesquisas e do aumento das datações sobre a ampla área de seu modelo. Neste sentido, é necessário um pouco de história para um resgate fiel dos acontecimentos. Em 1972, ${ }^{6}$ Brochado vai realizar seu doutoramento na Argentina, sem orientador definido, estando próximo tanto de Rex Gonzalez como de Eduardo Mário

\footnotetext{
${ }^{5}$ Correspondência entre Brochado e Meggers, acervo pessoal.

${ }^{6}$ Em 1971, Brochado é aceito para doutoramento na Universidad Nacional de La Plata, com data de afastamento de $1^{\circ}$ de setembro de 1972. Parte desta e de outras informações encontra-se na correspondência pessoal do prof. Brochado.
} 
Cigliano. No entanto, a situação instável daquela República o obriga a cancelar seus estudos. Em 1977, inicia seu doutoramento em Illinois, sob orientação de Donald Lathrap, e deveria concluí-lo em 1981. A Amazônia é um território de "litígio" acadêmico desde a década de 1960 e 1970. Assim, o modelo de expansão criado por Brochado vai corroborar as idéias de Lathrap sobre a precedência temporal das cerâmicas policrômicas na Amazônia central.

Se no início dos anos de $1980^{7}$ as idéias de Brochado possuíam grande vitalidade pelo mito da panacéia amazônica; nos anos de 1990 os dados arqueológicos começam a questionar a difusão proposta, seja pelo acúmulo de datações, ou pelo avanço da pesquisa no Norte do País (HECKENBERGER, NEVES e PETERSEN, 1998).

Além disso, se o uso de dados linguiísticos, etnográficos e históricos servem para realizar uma ponte entre os Guaranis dos séculos XV e XVI, dificilmente pode-se imputar a longevidade e permanência da cultura material para períodos mais recuados que o século XIV, que somam quarenta e cinco sítios de um total de cento e dezessete publicados com datas nãocalibradas (NOELLI, 1999/2000, p. 250-253).

Ademais, outras questões permanecem em aberto tanto no quesito arqueológico como histórico:

- os modelos existentes apontam os Guaranis como oriundos da bacia amazônica, de forma que se deve buscar, no registro arqueológico, por que o cultivo do milho sobrepõe-se ou superou ao da mandioca;

- da mesma forma, embora existam referências históricas aos assadores, deve-se questionar as causas que levam à ausência de registros arqueológicos aos pratos de assar farinha ${ }^{8}$ nos sítios Guaranis meridionais;

- faz-se mister a ampliação das pesquisas no que seria a rota de expansão proposta para os Guaranis, uma vez que, se esta foi através do rio Paraguai, as datações disponíveis no estado do Mato Grosso do Sul (MARTINS, KASHIMOTO, TATUMI, 1999) são mais recentes que no Sul e Sudeste do Brasil ${ }^{9}$

- da mesma forma, deve-se ter em conta que, se a origem dos Guaranis é na Amazônia, alguns elementos característicos (como o tratamento de superfície corrugado) são

\footnotetext{
${ }^{7}$ Brochado conclui seu doutorado em 1981, mas devido a problemas pessoais só voltou em 1984 para os EUA para defender seu trabalho (comunicação pessoal).

${ }^{8}$ Tampouco se encontram elementos que corroboremo processamento da mandioca amarga, como raladores, em todos os sítios do vale do rio Jacuí. Ademais, há uma inversão cronológica na dimensão dos assadores conhecidos etnográfica e historicamente falando, pois os assadores maiores são os mais recentes e, os menores, mais antigos (BROCHADO, não publicado, dezembro de 1975).

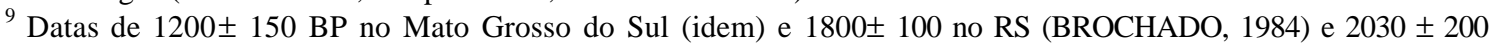
em São Paulo (MORAIS, 2000, p. 27).
} 
pratic amente inexistentes naquela área, ${ }^{10}$ o que dificultaria a localização de alguns "fósseisguias" para a determinação da expansão;

- ainda seguindo a idéia de expansão pelo rio Paraguai, as pesquisas deverão avançar fora do País, uma vez que a cerâmica cumancaya ${ }^{11}(\mathrm{AD} 810 \pm 80)$ apresenta semelhanças de forma e tratamento de superfícies (corrugado e pintura) e são contemporâneas às datações Guaranis;

Desta forma, diversos elementos apontam para uma solução ainda distante, pois se percebe que, uma vez que a origem do Prototupi ou da família Tupi-Guarani já é considerada um fato (e não mais uma hipótese), deve-se ter em conta a dinâmica destes grupos para determinar através de dados empíricos, quais são as plantas cultivadas e qual os equipamentos usados, indo mais além da informação histórica ou etnográfica.

Os conceitos de "tradição" e/ou "subtradição" não atendem mais às perspectivas de pesquisa arqueológica sobre os Guaranis, uma vez que não se está tratando simplesmente de variantes cerâmicos com predomínio de uma decoração sobre outra, ${ }^{12}$ mas grupos etnográfica e historicamente conhecidos, que, por sua vez, merecem um tratamento cada vez mais refinado no que concerne à definição ou identificação arqueológica destes grupos, principalmente considerando que, a partir dos avanços da História e da Antropologia, pode-se referir as parcialidades ${ }^{13}$ Guaranis, conceito conhecido, porém não adotado pelos arqueólogos, provavelmente porque as pesquisas não avançaram o suficiente para tecer hipóteses ou fazer afirmações neste sentido.

Embora nunca tenha sido publicado de forma extensa, Brochado já apontava em direção a que as fases arqueológicas no Rio Grande do Sul poderiam ser distintas, mas

\footnotetext{
10 A fase Caparu possui baixo percentual de corrugado (-5\%), ocorrendo somente associado com pintado. Localizado no rio Uatumã, a nordeste de Manaus, AM. Já a fase Urucari da tradição Jamari (baixo rio Jamari, a leste de Porto Velho, AC) não apresenta tratamento de superfície aparentado com os Guaranis. (MILLER et al.,1992)

11 "A semelhança da forma das vasilhas é inegável, porém não se pode afirmar se houve influência por parte da cerâmica Cumancaya sobre a Guarani, se aconteceu o inverso ou ambas foram influenciadas por uma terceira ainda desconhecida, pois não há informações sobre a região e as datações mais antigas para ambas são próximas ao ano 100 da nossa era (BROCHADO, comunicação pessoal, abril-1996). Veja Raymond, DeBoer e Roe (1975) " (SOARES, 1997, p.25, nota 24).

12 O conceito de Subtradição na Terminologia (1976, p.143) é assim descrito: "uma variedade da tradição Tupiguarani caracterizada, no seu conjunto cerâmico, pela predominância da decoração ... sobre as decorações...." (corrugada sobre pintada e escovada, por exemplo).

13 Ver índice de parcialidades históricas e etnográficas em Melià, Saul e Muraro, 1987, p.354. Do ponto de vista etnográfico, "estas parcialidades presentan diferencias significativas, no solo de nombre y de habitat, sino de cultura y modo de ser" (Melià, Grünberg e Grünberg, 1976, p. 177). Ver também Soares e Garlet, 1998.
} 
contemporâneas, $^{14}$ que poderiam ser traduzidas em distinções culturais e não étnicas. Infelizmente esta abordagem tampouco foi retomada, como será visto a seguir.

\subsection{Por uma arqueologia Guarani}

Os avanços da arqueologia Guarani foram enormemente computados a partir da proposta de alguns pesquisadores que, ainda que tenham participado do PRONAPA, sugeriram que as informações históricas poderiam ser utilizadas como fontes e pontos de partida para interpretação dos sítios arqueológicos. Brochado, assim, cria uma "escola", na qual seus seguidores farão da documentação histórica e etnográfica as referências obrigatórias para a reconstituição e compreensão das sociedades Guaranis pré-contato com os europeus (Ver NOELLI, 1993; BROCHADO, MONTICELLI e NEUMANN, 1990; BROCHADO e MONTICELLI, 1994; SOARES, 1996, 1997). Embora os pesquisadores reconheçam que as fontes históricas e etnográficas sejam pontos de partida para a formulação de hipóteses de trabalho, ocorreu que a multiplicação dos modelos e hipóteses não foi acompanhada pelas pesquisas de campo, no qual a ausência de escavações em áreas amplas comprometeu a coleta de dados primários (testemunhos arqueológicos), enquanto ocorria uma grande exploração e propostas interpretativas a partir das fontes escritas.

Se por um lado o PRONAPA foi repleto de limitações, percebe-se que muitos arqueólogos não ultrapassaram alguns pressupostos do programa e incorrem em outros tipos de erros, como por exemplo:

- a desvinculação dos artefatos a grupos humanos, utilizando as Fases e Tradições para classificar grupos humanos ao invés de tecnologias, como proposto por Ford (1962);

- a manutenção dos pressupostos de "unidade" (inicialmente na tradição Tupiguarani, depois Subtradição Guarani), entre os diversos grupos Guaranis;

- a mudança de terminologia (ou jargão acadêmico), mas a manutenção das técnicas de escavação e análise do material; ${ }^{15}$

- e para o âmbito deste trabalho, a desconsideração do solo antropogênico como artefato, ao invés de simples "evidência” da ocupação.

\footnotetext{
14 “É possível identificar vários grupos étnicos conhecidos historicamente: Tape, Cario, Arachã. A cerâmica mostra diferenças suficientes para justificar a subdivisão." (Correspondência entre Brochado e Evans e Meggers, 20 de outubro de 1975 e 12 de dezembro de 1975).

${ }^{15}$ Ver, por exemplo, os trabalhos de Rogge (1996; 1997; 1999).
} 
É importante enfatizar o ponto de vista adotado aqui a respeito de cada um desses itens. Em primeiro lugar, mesmo que seja reconhecida a ligação entre os Guaranis etnográficos, históricos e arqueológicos (SCHMITZ, 1985, p. 6; 1991, p.31), diversos trabalhos continuaram a tratar o Guarani no Sul do Brasil com a mesma terminologia, métodos e técnicas do programa (ROGGE, 1996; KLAMT, 1996a; SCHMITZ et al., 1990). Isso redundou na continuidade da desvinculação entre os artefatos e as sociedades, bem como na manutenção dos pressupostos de identificação e registro dos artefatos, sua cronologia e dispersão. Avaliando-se as conclusões e interpretações destes trabalhos, observa-se que os artefatos continuam existindo sem a presença das sociedades que os confeccionaram.

Em relação ao segundo ponto, mesmo que a arqueologia tenha sido ampliada em suas interpretações com as informações históricas e antropológicas, mantiveram-se as abordagens que colocavam uma "unidade" Guarani, fosse através da manutenção dos critérios do PRONAPA e dos conceitos propostos pela Terminologia (1976), ou pela manutenção do foco sobre o horizonte cultural, presente no termo "subtradição", proposto por Brochado. Neste sentido, ao tratar dos grupos durante os primeiros contatos, Susnik (1975, 1982, 1984/85) estabelece um critério espacial para referir-se aos Guaranis, referindo-se a estes como “altoparanaenses", "guaraienses", "guayraenses", “tapés”, "paranáes”, “itatines”, no sentido de que as diferenças de cultura material justificavam um tratamento diferenciado, tal qual o "achelense", "solutrense" ou "magdalenense" europeu.

Além disso, as diferenças existentes, em nível histórico e etnográfico, em poucos casos foram interpretadas como contatos interétnicos, geralmente tratados como intrusivos nos sítios. A respeito disto, Brochado já colocava, em 1975, as manifestações “exóticas” nos śtios arqueológicos Guaranis:

Algunos de los contatos culturales que empezaron por esta situación de recepción de cerámica de canje, pasaron, a veces muy pronto, a conformar verdaderos fenómenos de aculturación. Uno o más rasgos - casi siempre una técnica de decoración o de tratamiento de la superficie de la cerámica, a veces también una forma tipica de vasija - fueron copiado, sin producir cambios más profundos, de manera que la cerámica de la tradición mantuvo sus características generales.(...)Estos fenómenos de aculturación se advierten en unas 15 fases o manifestaciones distintas de la tradición tupiguarani (1975, p.106).

Brochado (1975, p.106 et seq.; 1980, p.54-55) prossegue demonstrando a influência e contemporaneidade da tradição Tupiguarani e outras, como Vieira, Aratu, Taquara, Una e Itararé. Segundo esse autor, o fenômeno de 'aculturação' ocorre de ambas as partes, tanto no sentido do Guarani influenciar como ser influenciado por outros grupos (no caso do texto, fases e tradições). Não cabe aqui reproduzir todas as fases nos quais estes elementos se 
apresentam, mas é importante evidenciar a convivência entre estes grupos que, segundo Brochado (comunicação pessoal), evidenciam influência mútua, como, por exemplo:

- sítios com cerâmica Guarani e Kaingang, com predomínio da primeira sobre a segunda;

- sítios com cerâmica Guarani e Kaingang, com predomínio da segunda sobre a primeira;

— sítios com cerâmica Guarani e Kaingang, com iguais percentuais entre ambas. ${ }^{16}$

É interessante que, contra o arcabouço propiciado pelo PRONAPA, Brochado assumiu a possibilidade de não existirem fronteiras culturais bem delimitadas e demarcadas espacialmente. Assim é que as referências aos artefatos de outros grupos em sítios fora de seu "habitat" continuaram a ser considerados "intrusivos", mesmo após dez anos do final do programa (SCHMITZ; BARBOSA e RIBEIRO, 1978/79/80).

Ao mesmo tempo, é impossível imaginar que um grupo possa manter-se sem alterações em um espaço de tempo de 1400 anos (do ano 100 a 1500 desta Era), desde o Mato Grosso até a foz do rio da Prata, em ambientes tão distintos como o campo, o cerrado e a floresta subtropical, sem adaptações locais e sem distinções socioculturais (BROCHADO, 1975, p. 110 e 1980, p.52).

Ademais, na possibilidade de a sociedade Guarani manter sua organização sóciopolítica em períodos recuados, anteriores ao contato (SOARES, 1997, p. 160-202), deve-se ter em conta a submissão de outros grupos não-Guaranis, de imposição/absorção da cultura material, bem como influências recíprocas como citadas acima por Brochado. Seria o caso da cerâmica Guarani em cerritos do Sul do Brasil e República Oriental do Uruguai, em que o tratamento de superfície é copiado, mas as formas e as dimensões são distintas das vasilhas usualmente atribuídas aos Guaranis.

Acredita-se que os Guaranis compunham sociedades muito mais complexas que aparentemente podem ser classificadas, e, como já demonstrado, ocupavam todos os recursos disponíveis em termos ambientais (ver item 1.1 desta tese). Ao mesmo tempo, são socie dades dinâmicas, de forma que a criação de um modelo explicativo sobre os Guaranis deve contemplar esta dinâmica interna, ${ }^{17}$ que pode ser diferente para cada grupo. Desta forma, o que se apresenta a seguir é uma tentativa de definição e sugestões que possam ser perseguidas

\footnotetext{
16 “O registro arqueológico sugere tanto relações amigáveis com possível coexistência entre os diferentes grupos (fragmentos de cerâmica Itararé em sítios Tupiguarani e vice versa [CHMYZ 1968A; DE MASI \& ARTUSI 1985; MENTZ RIBEIRO et al. 1994]" ( ARAÚJO, 2001, p. 33).

${ }^{17}$ Ver, por exemplo, o efeito das conquistas em Soares e Noelli, 1997a e 1997b.
} 
para delimitar melhor quais elementos são perceptíveis em uma escavação arqueológica que poderão indicar as diferenças existentes dentre os próprios Guaranis. Ao mesmo tempo, provar que a abordagem aqui escolhida encontra respaldo justamente nesta dinâmica social, cultural, material e relacional, no qual se privilegia o registro arqueológico, na medida em que se pode perseguir os elementos materiais que se encontram na documentação histórica e etnográfica, mas não o contrário.

Em terceiro ponto, vê-se a modificação do jargão arqueológico, mas a permanência dos princípios histórico-culturalistas, através da descrição exaustiva do material arqueológico. As conclusões seguem reduzidas e colocam as informações históricas de forma que os artefatos referendam as fontes escritas. Desta forma, a interpretação dos dados arqueológicos tomou-se limitada e, em algumas publicações, utilizam as fontes históricas para explicar contextos arqueológicos, uso e função de artefatos (ROGGE, 1996; SCHMITZ, 1991; SCHMITZ et al., 1990; SCHMITZ, 1999). O objetivo deste trabalho é apresentar uma proposta de análise dos artefatos associados aos antepassados dos Guaranis, que consigam respaldo somente na leitura arqueológica, por isso não se deterá nos pontos acima destacados.

E, por último, a análise do solo antropogênico com artefato passível de análise, indo além da associação "mancha preta"= habitação. No item 2.2.4 desta tese, analisar-se-á, dentro das possibilidades do momento, os sedimentos como resultado da ação humana, mas é importante salientar que, uma vez que a escavação em arqueologia é um processo destrutivo, a coleta e análise de sedimentos podem, sem grandes custos, ampliar o leque de interpretações a respeito de dieta, permanência, uso do solo e uso social do espaço, como será visto no referido item.

Deve-se começar pelo desligamento de uma proposta amplamente aceita na atualidade, que é a ligação direta entre Guaranis etnográficos, históricos e arqueológicos. Não se nega que esta ligação exista, mas, antes disso, apontar-se-á os desdobramentos negativos que esta proposta trouxe, como colocado anteriormente.

Não se trata de simplesmente desvincular cultura material e grupos étnicos, dizendo, por exemplo, que os Guaranis pré-históricos nada têm a ver com aqueles historicamente conhecidos ou com os atuais. Tirar esta conclusão seria negar a sustentabilidade de uma quantidade infindável de dados arqueológicos, lingüísticos, etnográficos e etnohistóricos que apontam uma grande coincidência entre os locais dos sítios arqueológicos e os relatos sobre indígenas que viviam em nosso país na época do contato. Trata-se, ao contrário, de aceitar a possibilidade de os grupos étnicos serem vistos como entidades dotadas de um caráter situacional e fluido, repensando, desta forma, as tradições e subtradições utilizadas na Arqueologia até o presente momento (OLIVEIRA, 2002, p.97-98, grifo nosso). 
Em primeiro lugar, mesmo que haja uma continuidade entre os Guaranis atuais e os arqueológicos, é sabida a existência de diversas parcialidades distintas entre os Guaranis (SOARES e GARLET, 1998). Este fato pode direcionar as atuais pesquisas na busca de diferenças entre as formas como se manifesta o padrão de assentamento, as dimensões de aldeia, bem como tratamento de superfície e pinturas cerâmicas, analisados ao mesmo tempo. Esta proposta se encontra desde os trabalhos iniciais de Brochado (1975 e 1980).

Da mesma forma, não se pode atrelar a tradição tecnológica (técnica de confecção cerâmica) aos falantes de determinada língua. Embora uma prática recorrente na arqueologia Guarani pela sua própria história, a identidade cultural não pode ser relacionada diretamente a um conjunto de artefatos (FUNARI, 1999a; JONES, 1997), ademais, frente aos contatos e influências mútuas colocadas acima.

Embora seja uma prática ainda recorrente, percebe-se que a cultura material segue sendo o critério de identificação étnica em arqueologia Guarani. Esta idéia remonta a Gustav Kossina, como salienta Oliveira (2002, p.32):

A obra de Kossinna Die Herkunft der Germanen (A Origem dos Germanos), publicada em 1911 é, segundo Trigger, o primeiro trabalho sistemático de uma série de outros que aceitariam a correlação entre os achados arqueológicos, agrupados no conceito de cultura arqueológica, e grupos étnicos. Em seu trabalho há uma nítida relação entre as variáveis língua, etnia e cultura material, culminando na idéia de que uma continuidade na cultura material denotaria uma continuidade étnica.

Por outro lado, a tentativa de vincular uma cultura arqueológica a um grupo étnico ou mesmo atribuir uma relação entre fases arqueológicas e "parcialidades", como propunha Meggers e Evans (1985, p. 5), ainda é tema de discussão e encontra-se em aberto. A passagem de Wiiley e Phillips (1958, apud CHANG, 1976, p.52) é esclarecedora:

En suma, parece que la coyuntura es contraria a considerar que las fases arqueológicas posean un alto grado de realidad social, si es que tienen alguna, pero ello no nos impide seguir afirmando que pueden tenerla y que de momento podemos actuar como si la tuvieran.

Ao mesmo tempo, propõem-se aqui, apresentar elementos que contribuam na interpretação dos dados arqueológicos, principalmente a partir da análise da distribuição dos artefatos e, secundariamente, na utilização de contribuições propiciadas por diálogos interdisciplinares. Deixa-se claro, mais uma vez, que, neste momento, esta abordagem é realizada com algumas contribuições das ciências da terra, especificamente na análise do solo 
antropogênico como um artefato; contudo, em outro momento posterior a esta tese, buscar-seá ampliar interpretações através da contribuição das disciplinas das humanidades.

Assim, ainda na questão da etnicidade em arqueologia Guarani, retomar-se-ão algumas idéias existentes na troca de correspondência entre Brochado e outros pesquisadores que apontam para uma abordagem arqueológica e, ao mesmo tempo, étnica dos Guaranis, mas que nunca foi levada a cabo por fatores que não valem a pena serem explorados.

Sendo assim, a argumentação é pessoal, mas as sugestões encontram-se nas cartas depositadas no Museu Arqueológico Diretor Pestana, em Ijuí (RS), e nas suas cópias e de outras correspondências no acervo pessoal do professor Brochado.

Em 1971, portanto durante a vigência do programa, Brochado já colocava que as fases arqueologicamente conhecidas poderiam ser associadas a grupos étnicos. No relatório do segundo semestre de 1971, encaminhado ao CNPq, Brochado coloca que as fases Vacacaí A e B:

foram identificadas como tendo origem no início de um processo de aculturação entre os índios portadores da fase Vacacaí e os missionários jesuítas espanhóis, no início do século XVII. Desta maneira, os portadores da fase Vieira foram identificados com os índios Tapes, referidos historicamente como habitando a região do Tape, correspondente ao interior do atual estado do Rio Grande do Sul (relatório segundo semestre de 1971).

Como já colocado anteriormente, também a associação entre as "manchas pretas" e as casas estavam presentes nos relatórios desde 1967 (Relatório primeiro semestre de 1967), mas, se por um lado, foram publicados; por outro, dados como as primeiras tentativas de estabelecer um padrão de habitação (como publicado posteriormente, em 1975, p. 110 et passim), foram rejeitados.

Outros elementos, mesmo estando presentes em algumas publicações, como as distintas adaptações dos Guaranis aos distintos ambientes, ainda estão por ser explorados (LOPONTE e ACOSTA, 2003, p.131), como as adaptações em ambientes de campo, de floresta de araucária, de banhados e outros.

Da mesma forma, as pinturas existentes nas vasilhas, que poderiam ser indicativos de distintas parcialidades, somente em caráter experimental têm sido pesquisadas (SOARES e KLAMT, em preparação). Embora as pesquisas etnográficas tenham colocado luzes sobre esta questão, ${ }^{18}$ esta pesquisa ainda está por ser realizada por arqueólogos.

\footnotetext{
${ }^{18}$ Em sua tese de doutoramento, Sérgio Batista da Silva apresenta os motivos das pinturas, compilados em publicações arqueológicas, aos Mbyá-Guaranis, que reconhecem parte dos motivos. Coincidência ou não, os motivos atribuídos aos Carijós (Guaranis do litoral catarinense), não são reconhecidos pelos Mbyás (SILVA,
} 
A proposta de Morais (1999/2000, p. 207) de tratar a questão como um Sistema Regional Guarani tem diversas vantagens, como a extrapolação da tradição Tupiguarani, Subtradição Guarani ou tradição Guarani. Em todos estes casos, estão se tratando somente de uma parcela da sociedade, representada por sua cultura material e, neste sentido, não se avançaria além do histórico-culturalismo. No momento em que Morais (op. cit.) aponta para o uso dos dados etnográficos e históricos, mantém-se ligado aos pressupostos da etnoarqueologia, sem abandonar as nuances regionais.

Mesmo que não se tenha atualmente subsídios para tanto, acredita-se que se poderá caminhar na atribuição étnica para uma Arqueologia Guarani, através do somatório dos seguintes elementos:

- os atributos artísticos da cerâmica (pintura, motivo, formas das vasilhas, local das pinturas, etc.);

— a localização das parcialidades historicamente identificadas;

— os distintos ambientes que compõem o padrão de assentamento Guarani;

- a análise química da cerâmica, através da "assinatura" proveniente da análise de terras raras. $^{19}$

Desta forma, buscando ultrapassar os atributos de tradição e fase, propõe-se uma abordagem que seja o resultado da adição de diversas análises (como citadas acima) que, juntamente com subsídios da lingüística e antropologia, defina uma Arqueologia Guarani, que trate tanto da diferença como da similaridade existente na cultura material.

Esta proposta de abordagem para os Guaranis é resultado da construção de um catálogo de vasilhas Guaranis inteiras depositadas em museus no Estado do Rio Grande do Sul (SOARES e KLAMT, em preparação). Neste catálogo, estão fotografadas as vasilhas arqueológicas atribuídas aos antepassados dos Guaranis, com as respectivas dimensões, registro de pintura e/ou tratamento de superfície, local de origem e instituição de acervo. Até o momento, pode-se observar que, se por um lado existe a continuidade das formas das vasilhas na categoria panelas (yapepó); por outro, não existe a mesma coincidência em outras categorias funcionais, como tigela de beber, por exemplo, (cambuchi caguabâ). Outras análises e relações poderão ser estabelecidas, como será visto no item sobre análise de cerâmica.

\footnotetext{
2001, p.223-238).

19 'Estudo de assinaturas químicas em Cerâmicas Guarani, de origem arqueológica, usando a técnica de ablação laser - espectrometria de massas de dupla focalização com fonte de plasma induzido (LA -HR-ICP-MS)", qualificação de doutoramento de Irene Akemi T.Bona, IPEN, USP, 2003.
} 
A interdisciplinaridade ${ }^{20}$ em arqueologia deve ser uma prática cotidiana, e não apenas restrita à formação do arqueólogo. Neste estudo de caso, foram realizadas pesquisas sobre cerâmica no Instituto de Pesquisas Energéticas Nucleares - IPEN/USP, bem como análises de solo no Embrapa Solos/RJ, Museu Emílio Goeldi/PA e Laboratório de Solos /UFSM. Ademais, outros processos em andamento estão sendo desenvolvidos, como a separação química de fitólitos, pelo laboratório de química da UFSM.

Por fim, acredita-se que, neste momento, a contribuição consiste em apresentar as possibilidades interpretativas que a abordagem interdisciplinar proporcionou para esse estudo de caso em arqueologia Guarani. Por meio da contribuição com algumas análises pontuais, advindas das ciências da Terra, como citadas acima, acredita-se que se ampliam os caminhos pelos quais se infere o cotidiano e o funcionamento desta sociedade. Em outra ocasião, posterior a esta tese, pretende-se ampliar as abordagens sobre este sítio com a criação de hipóteses com base na documentação etnográfica e histórica.

\footnotetext{
${ }^{20}$ Para a definição de interdisciplinaridade utilizada nesta tese, utilizou-se Soares (1997, p. 52-58). Para uma breve apresentação da interdisciplinaridade forte e fraca, ver Machado (1995).
} 


\section{O SÍTIO RS-JC-57 (WILMOTH RÖPKE): BREVE INTRODUÇÃO}

O vale do rio Jacuí tem sido objeto de pesquisa arqueológica há bastante tempo. ${ }^{1}$ Trabalhos como os de Ribeiro $(1991,1991 a)$ registram ocupação humana no vale desde três mil anos antes do presente (caçadores/coletores) até o período colonial (BROCHADO, 1970, 1971). ${ }^{2}$ É importante destacar também a publicação de Schmitz, Rogge e Arnt (2000), que divulga os dados referentes ao salvamento arqueológico do empreendimento realizado na década de 1980.

O sítio RS-JC-57 foi escavado por um programa de salvamento arqueológico promovido pelo consórcio da construção da barragem hidrelétrica no município de Dona Francisca, Dona Francisca Energética SA (DFESA) e a Companhia Estadual de Energia Elétrica (CEEE) no período de março de 1999 até novembro de $2000 .^{3}$

Esta pesquisa in loco foi realizada em virtude de um novo estudo de impacto ambiental, para a construção da usina hidrelétrica supracitada, tendo como objetivo atender à legislação vigente. Como grande parte dos sítios já haviam sido trabalhados pelos pesquisadores anteriormente citados, as novas visitações atenderiam basicamente ao registro do grau de destruição e à localização exata desses sítios. Sendo assim, o objetivo deste trabalho era a re-localização dos sítios conforme as novas diretrizes do IPHAN, com o registro do estado de destruição dos mesmos.

Inicialmente, apresentar-se-ão as atividades desenvolvidas na localização no sítio RSJC-57 e a problemática suscitada a partir dos vestígios encontrados. Sendo assim, o desenvolvimento do texto seguirá a ordem cronológica dos acontecimentos que culminaram na escavação do sítio.

O sítio RS-JC-56/57 foi escavado em 1989-1990, sob coordenação do arqueólogo Prof. Dr. Pedro Augusto Mentz-Ribeiro. O pesquisador, inicialmente, coletou o material cerâmico

\footnotetext{
${ }^{1}$ Ver Klamt, 1996.

${ }^{2}$ Brochado, José Proenza. Pesquisas Arqueológicas nos vales do Jacuí e Vacacaí, PRONAPA 4, 1971, p. 11 - 35. Schmitz, P. I. e Brochado, J. P. Petroglifos no estilo pisadas no cent ro do Rio Grande do Sul, Pesquisas, Antropologia n³4, 1982, p. 03-47. Schmitz, P. I; Ribeiro, P. A. M.; e Ferrari, J. Salvamento Arqueológico no Médio Jacuí, RS - Barragem Dona Francisca, 1981. São Leopoldo, IAP, 18 p. Relatório para a Companhia Estadual de Energia Elétrica.

${ }^{3}$ Foram responsáveis pelo salvamento o Centro de Ensino e Pesquisas Arqueológicas - CEPA - UNISC, coordenado pelo Arqueólogo Sérgio Klamt e o Laboratório de Estudos e Pesquisas Arqueológicas - LEPA UFSM, coordenado pelo Arqueólogo Saul Milder.
} 
presente na várzea do rio Jacuí, disperso em uma área de, aproximadamente, seis hectares, através de coleta aleatória de superfície, ${ }^{4}$ material hoje depositado no Centro de Estudos e Pesquisas Arqueológicas (CEPA) da Universidade Integrada de Santa Cruz (UNISC).

Através da retificação de um talude próximo à várzea de inundação do rio Jacuí e contíguo à área de dispersão de fragmentos, o pesquisador coletou fragmentos de ossos humanos, material ósseo, conchífero, fragmentos cerâmicos e material lítico. Dada a estratigrafia do talude estar disposta em lentes e as camadas estratigráficas estarem reduzidas a pequenas manchas, o sítio foi considerado destruído e sem potencial de escavação arqueológica, embora fosse um dos raros que apresentasse material ósseo em condições de escavação. Tendo em vista a reavaliação dos trabalhos desenvolvidos anteriormente, retornouse ao local para novas sondagens e análise de potencial de escavação do sítio.

É importante observar o que escreve Ribeiro (1996, p.18) a respeito do sítio RS-JC-57:

A profundidade dos sedimentos com sinais de ocupação é rasa, isto é, atinge 15 a $20 \mathrm{~cm}$. Apenas um local atinge mais profundidade, mas pouco resta do antigo sítio (erodido pelas águas do rio). Como os sítios estão assentados sobre locais de cultivo, encontram-se praticamente destruídos.

A hipótese inicial deste pesquisador era de que o material era proveniente de um sítio superficial localizado na várzea acima, ou seja, a erosão teria destruído o sítio, restando apenas evidências totalmente descontextualizadas. Tendo em vista a reavaliação dos trabalhos desenvolvidos anteriormente, retornou-se ao local para novas sondagens e análise de potencial de escavação do sítio. Sendo assim, o sítio foi reavaliado a partir das evidências existentes no talude do rio, no qual se realizaram novas escavações, nesta área e no núcleo antropogênico localizado posteriormente.

\subsection{A localização do sítio na paisagem}

\subsubsection{Metodologia aplicada para a localização e escavação do sítio}

A metodologia aplicada para a localização deste sítio partiu dos pressupostos adotados por Pallestrini $(1968 / 69,1969,1972 / 73,1975)$, adaptados a partir dos trabalhos de LeroiGourhan e Brézzilion (1965, 1972). No caso da localização do sítio, utilizaram-se diversas

\footnotetext{
${ }^{4}$ Consideraram-se as coletas assistemáticas e aleatórias em virtude de os fragmentos não apresentarem nenhum tipo de referência espacial. O pesquisador coletava os fragmentos em sacos de alinhagens recolhidos através de transects ao longo das áreas cultivadas.
} 
etapas para identificação e reconhecimento das diferentes estruturas de ocupação. As etapas foram as seguintes:

- caminhamento a pé para re-localização do sítio a partir das referências existentes em trabalhos anteriores;

- identificação de vestúgios na superfície;

- mapeamento da área de dispersão dos vestígios;

- realização de trincheiras multidirecionais para localização das ocupações em camadas sub-superficiais;

- topografia do terreno;

- escavação.

A metodologia aplicada para localização de sítios arqueológicos obedeceu à proposta de Redman (1973), na qual a área passou por um "reconhecimento geral", visando à compreensão das diversas características físicas e ambientais da área. O caminhamento limitou-se a percorrer a várzea do rio, observando-se as áreas que apresentavam condições geomorfológicas para a implantação de sítios. Percorreram-se as áreas a pé, procurando contemplar tanto as informações existentes das pesquisas anteriores como as informações oportunísticas proporcionada pelos agricultores.

No presente estudo, a forma mais adequada de realizar um levantamento é através de transects, linhas de caminhamento sistemático que observem não uma parcela da área, mas sua totalidade (REDMAN, 1973).

Verificou-se também a densidade de sítios passíveis de serem registrados, observando as variáveis vegetação $x$ declividade do terreno $x$ distância de cursos d'água (KIPNIS, 1996, p.37), pressupondo que, quanto maior a declividade do terreno (acima de $30^{\circ}$ ) e a distância do curso d'água (até 1000 metros distante), menor é a probabilidade de se localizarem sítios, levando-se em conta a comunidade biótica (mata, cerrado ou campo) na qual este possa estar inserido para a realização dos transects.

Mesmo este levantamento sendo sistemático, a localização do sítio fica prejudicada em áreas pouco conhecidas arqueologicamente, por alguns fatores, do qual salienta-se o mais importante (ALEXANDER, 1983 apud MELLO, 1996, p.17), que é a natureza da prospecção. A tradicional depende pesadamente da exposição do solo para a localização da cultura material; o vestígio arqueológico tem de estar aflorando para ser encontrado pelo arqueólogo, e isso só acontece em terrenos que se apresentam erodidos ou em áreas que acabaram de ser aradas. A limitação destes fatores supracitados é que, provavelmente, induziu ao erro os 
arqueólogos anteriores, uma vez que parte dos vestígios encontravam-se a uma profundidade maior que a usualmente aceita para os sítios Guaranis.

A partir disso, foram realizadas as trincheiras que delimitaram a ação da intervenção topografia e escavação - no terreno. Como visto acima, a carga sedimentar que cobria o local do sítio é composta por sedimentos oriundos da Serra Geral e possíveis depósitos provenientes das enchentes do rio. Tendo isso em conta, percebe-se a estratigrafia que compõe o local de habitação e área de descarte.

Os pressupostos, aqui, seguem, de maneira geral, àqueles propostos por Pallestrini (1975, p. 25), seguindo a ordem de limpeza de área a ser escavada, topografia, quadriculamento e "ataque" em superfície. Com isso, resgata-se o conceito de décapage proposto por Leroi-Gourhan e Brézillion (VOCABULAIRE, 1972, p.321) "que consiste em seguir os movimentos de um solo fóssil respeitando minuciosamente a manutenção em seu lugar, de todos os vestígios", controle esse obtido através da inserção plani-altimétrica dos artefatos. No próximo item, descrever-se-á o que foi considerado artefato para fins deste estudo.

Salienta-se também, como já referido, que esta inserção não considerava os artefatos de forma isolada, mas a partir do conceito de "estrutura", como colocado na introdução desta tese. Ou seja, grupos de cerâmica, lítico ou ossos com proximidade inferior a cinco centímetros receberam um único número relativo a sua inserção plani-altimétrica. Este procedimento facilitou tanto a colagem de peças como a remontagem de núcleos líticos, artefatos em elaboração e vasilhas cerâmicas.

Assim, como será visto adiante, esta metodologia proporcionou não só a localização dos artefatos, mas também sua relação no espaço e os processos pós-deposicionais que interferiram após o seu abandono. Ainda no que concerne à metodologia aplicada, foram coletadas amostras de solo antropogênico e não-antropogênico da área de descarte e do NSA, o que proporcionou análises quanto a composição e gênese destes solos.

\subsubsection{Escavação do sítio}

O sítio objeto de estudo deste trabalho, denominado RS-JC- 56 e 57, está localizado nas glebas 89 e $89^{a}$ do cadastramento realizado pelo consórcio de construção da Usina, de propriedade de Wilmoth Röpke, no município de Ibarama, RS.

As coordenadas geográficas dos pontos extremos e do centro da escavação encontramse abaixo (Anexo 1: mapa 1, 2 e 3) : 
Coordenadas em metros a partir de Mercator (UTM):

$$
\begin{array}{ll}
N=6.740 .538,112 & E=279.151,293 \\
N=6.740 .443,634 & E=279.045,299 \\
N=6.740 .476,532 & E=279.152,497
\end{array}
$$

As coordenadas correspondentes em graus a partir de Greenwich:

$$
\begin{array}{ll}
\mathrm{S}=29^{\circ} 26^{\prime} 45^{\prime \prime} & \mathrm{W}=53^{\circ} 16^{\prime} 41^{\prime \prime} \\
\mathrm{S}=29^{\circ} 26^{\prime} 44^{\prime}, & \mathrm{W}=53^{\circ} 16^{\prime} 37^{\prime} \\
\mathrm{S}=29^{\circ} 26^{\prime} 42^{\prime \prime} & \mathrm{W}=53^{\circ} 16^{\prime} 37^{\prime \prime}
\end{array}
$$

Como era perceptível uma estratigrafia no talude, a equipe ${ }^{5}$ procurou retificar e escalonar o perfil natural da borda do rio para examinar a sequiência estratigráfica dos depósitos antrópicos e aluvionais (ver Desenho 1).

\section{Retificação dos taludes e escavação}

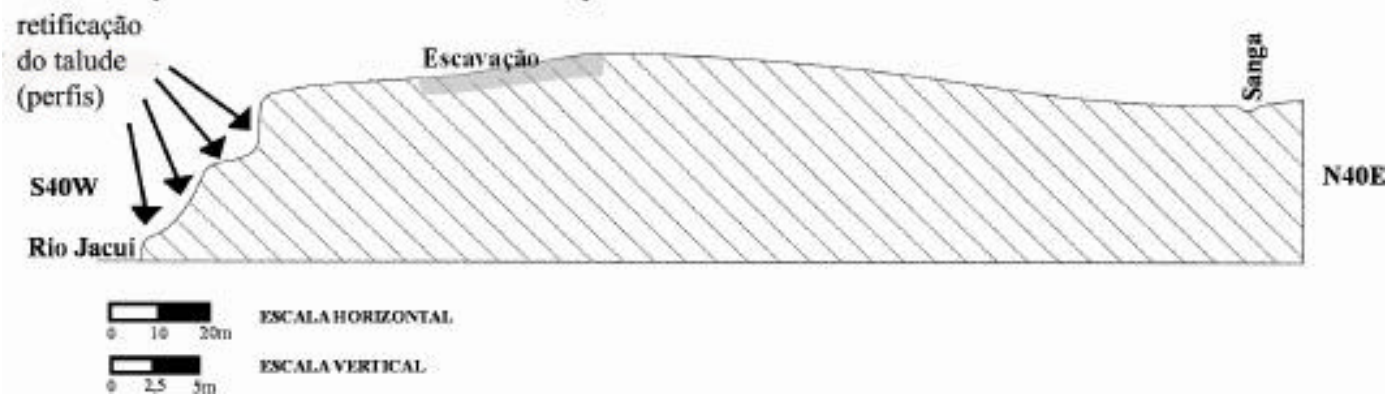

Desenho 1 - Perfil do local do sítio, com a barranca do sítio à esquerda. O croqui original está publicado em Schmitz, Rogge e Arnt (2000, p.207), modificado pelo autor.

Dessa forma, foram realizados diversos escalonamentos ('degraus') no talude do rio para observar as evidências ainda existentes e avaliar o estado de destruição do sítio. Os depósitos antrópicos, compostos de diversas lentes de solo antropogênicos, ${ }^{6}$ demonstraram que a barranca do rio não era propriamente uma habitação, mas depósitos de refugos e sobras da ocupação humana, como denominado, a área de descarte.

\footnotetext{
${ }^{5}$ A equipe da Universidade Integrada de Santa Cruz (UNISC) foi coordenada pelo professor Sérgio Célio Klamt e a equipe da Universidade Federal de Santa Maria (UFSM) pelos professores Saul Milder e André Soares.

6 "Núcleo de solo antropogênico é um tipo de assinatura dos povos pré-coloniais, corrente nos sítios de agricultores. Conhecido por mancha preta, é um corpo sedimentar remanescente de antigos solos de habitação e seu cinturão envoltório, depósitos de lixo, áreas de cocção de alimentos, etc. Surge como manchas ovaladas de solo enegrecido pelo elevado teor de materiais biogênicos coletados, processados e descartados pelas comunidades pré-coloniais, rico em evidências arqueológicas, principalmente fragmentos de cerâmica e estruturas de combustão. No caso do sistema regional Guarani, são, com freqüência, os remanescentes da 'tapy iguassu', a casa-grande e seu entorno" (MORAIS, J.L Glossário de termos em uso no projeto Paranapanema,
} 
2.1.2.1 A escavação na área de descarte (talude do rio)

A intervenção no talude deu-se pela retificação escalonada de terraços, que expôs uma estratigrafia complexa, na qual as camadas compunham-se de areia grossa fluvial, intercalada por lentes de solo antropogênico. Realizaram-se vários cortes que apresentaram uma homogeneidade estratigráfica, ou seja, exibiram sedimentos fluviais areno-argilosos com lentes de solo antropogênico ricos em evidências cerâmicas, líticas e biológicas (Anexo 2: Fotos 1 e 2).

Percebeutse que as lentes de solo antropogênico eram resultado da deposição de materiais descartados. Os depósitos (lentes) de solo antropogênico são relativamente uniformes, com as extremidades delgadas e o centro um pouco mais espesso. Assim, pôs-se à mostra um terraço inclinado com aproximadamente $45^{\circ}$ (quarenta e cinco graus) e oito metros de altura. $\mathrm{O}$ escalonamento $\left(1^{\circ}\right.$ degrau $)$ foi feito no fundo do canal do meandro do rio.

Alguns elementos que corroboraram com a hipótese de que o local era uma área de descarte e não um sítio destruído pela ação das águas do rio: a heterogeneidade da estratificação e a presença de artefatos somente nos núcleos de solo antropogênicos (NSA), uma vez que, no entorno desses, os sedimentos são estéreis.

Os cortes (perfis) foram registrados em croquis, representando os estratos depositados no talude do rio (Anexo 1: Desenho 2 e Anexo 2: Fotos 1, 2, 3 e 4) e mostrando mais de dez metros de talude desde a planície até o meandro.

Uma vez que esses depósitos haviam sido considerados como o próprio sítio pelo arqueólogo anteriormente citado, a etapa seguinte foi determinar a origem dos refugos, já que as sondagens realizadas no salvamento anterior ${ }^{7}$ não localizaram sítios na várzea próxima ao talude citado.

Dada a extensão da várzea (com mais de dez quilômetros de extensão e seiscentos metros de largura no local do talude), optou-se pela abertura de trincheiras multidirecionais (Anexo 1: Desenho 3, Anexo 2: Foto 5), com largura de aproximadamente um metro e profundidade média de um metro e meio de altura cavadas com pá mecânica. Como o tempo disponível para o salvamento era limitado e a bibliografia existente remetia a diversos sítios destruídos ao longo do vale, a realização de trincheiras com tal pá viabilizaria a exploração e a cobertura de uma grande extensão em pouco tempo.

\footnotetext{
sem data).

${ }^{7}$ Realizado por Schmitz, Ribeiro e Ferrari, ver nota 2.
} 
Posto que a utilização de pá mecânica pudesse destruir parte das evidências, a cobertura conseguida por meio desse tipo de atividade seria muito mais ampla que a cobertura resultante por meio de trincheiras tradicionais ou ainda pela realização de sondagens tipo "cabine-telefônica" ${ }^{8}$ (sondagens de $1 \mathrm{~m}$ x $1 \mathrm{~m}$ ), considerando a área a ser prospectada. É pertinente ressaltar que, devido ao acompanhamento dos arqueólogos, qualquer sinal de ocupação presente nos cortes realizados pela pá mecânica poderia dar início às escavações sem grande prejuízo do sítio. Tais cortes possibilitam um perfil com grande densidade de ocupação ou mesmo de ocupações do local. Dessa forma, a técnica utilizada cobriria uma grande área em curto espaço de tempo, delimitando as áreas que poderiam sofrer intervenção posterior e determinando a profundidade a ser escavada e a espessura da ocupação em questão.

Em uma das trincheiras, a uma distância de aproximadamente quarenta e oito metros, foi localizado um núcleo de solo antropogênico (NSA), a uma profundidade de sessenta centímetros, com abundante quantidade de artefatos. Tal achado foi considerado uma ocupação pretérita, provavelmente uma estrutura habitacional. Cabe ressaltar que em razão das metodologias empregadas no passado e a falácia sobre as ocupações Guaranis, ou seja, que suas evidências se situavam em uma profundidade em torno de cinqüenta centímetros, este sítio não foi localizado.

Como os sedimentos que recobriam o sítio se alojavam a mais de sessenta centímetros de profundidade, preferiu-se retirar os sedimentos superiores com pá mecânica, porque se tratava de solo atual revolvido pelo arado e de uma camada estéril que recobria o NAS. Embora as camadas fossem de mesma textura e coloração, sabia-se que os arados utilizados na região, atualmente, não alcançam profundidades superiores a trinta centímetros, o que garantia a inviolabilidade do sítio por perturbações modernas de uso agrícola. É importante entender que se trata de um sítio com apenas uma ocupação em profundidade, sem interferências ou justaposições de outras ocupações.

A escavação, então, foi desenvolvida em dois momentos: no primeiro, houve a relocalização do sítio RS-JC-57, com a determinação da área de descarte e sua escavação; no segundo, a localização da proveniência dos refugos e a delimitação do sítio a ser escavado. A coleta do material foi dividida, para fins de catálogo, em materiais oriundos da área de descarte; os artefatos da trincheira; coleta superficial na várzea do rio; e a escavação do NSA. Os artefatos analisados serão apresentados oportunamente.

\footnotetext{
${ }^{9}$ Síndrome de “telephone booth”, Flannery (1976, p.3 apud NOELLI, 1993, p.40).
} 


\subsubsection{A escavação do NSA ("habitação")}

A pesquisa de campo, neste sítio, foi realizada em cinqüenta e cinco dias, em diversas temporadas, ao longo dos anos de 2000 e 2001. Conforme exemplo citado nas escavações do Projeto Paranapanema, realizado em São Paulo, adotou-se o seguinte procedimento:

o método das superfícies amplas proporciona o levantamento de aldeias e de acampamentos pela correta aplicação de técnicas apropriadas como a limpeza ampla e o levantamento planialtimétrico (...) o método etnográfico, por meio de decapagens em microníveis naturais, proporciona a leitura do contexto dos materiais... (Morais, 1995, p.84)

Essa atividade compreendeu as seguintes etapas de trabalho fundamentadas em Milder e Soares (2002, não publicado):

- delimitação da área a ser escavada, com base nas evidências encontradas nas trincheiras, compreendendo um espaço de ocupação humana e seus limites antrópicos e geológicos;

- quadriculamento da área em setores de dimensões variáveis, delimitados pelas trincheiras de sondagem estratigráficas;

- inserção planialtimétrica do material, a partir do nível de ocupação superior, considerando esta como um único momento de ocupação humana, dada a ausência de vestígios que possibilitassem a identificação de outras ocupações pretéritas ou posteriores;

- escavação dos níveis naturais, com documentação gráfica e Fotográfica dos artefatos, ecofatos, ${ }^{9}$ bioturbações e pedoturbações (presentes por causa da composição argilo-arenosa);

- numeração individual dos artefatos líticos, ósseos e cerâmicos, permitindo a plotagem bidimensional (inserção plani-altimétrica) e definição de estruturas;

- retirada de amostras de solo antropogênico e não-antropogênico, com o objetivo de realizar análises físico-químicas dos seus componentes.

Cabe dizer que, neste estudo, a escavação do NSA da várzea foi realizada concomitante com a da área de descarte.

Primeiramente, deve-se ter em conta que o local do sítio deve ser visto em escala aproximativa a partir dos mapas 1, 2 e 3 (Anexo 1), que inserem o sítio no mapa político para abordá-lo a partir da geografia da região. O rio Jacuí corta a Serra Geral no sentido norte-sul

\footnotetext{
${ }^{9}$ Para o conceito de artefatos, biofatos e ecofatos, ver Renfrew e Banh (1993, p. 41 e seguintes).
} 
no local da usina, sendo que o sítio está localizado na várzea conforme Foto aérea (Anexo 1, Foto 1).

A topografia do local foi realizada em dois momentos: a partir da identificação do núcleo de solo antropogênico e sua escavação. Uma vez que era fundamental a implantação geomorfológica do sítio para possíveis interpretações posteriores, realizou-se um mapeamento topográfico do sítio e do entorno, em curvas de nível de um metro de altura.

Neste sentido, a área do sítio fica sujeita às enchentes do rio que, em seu momento de maior expansão, envolve a sanga existente à nordeste, transformando assim o local em uma "ilha" momentaneamente, sendo que o local do sítio não é atingido pelas águas. É interessante observar que, à jusante do rio, as várzeas são utilizadas para cultivo de arroz, enquanto no local do sítio a agricultura atual era representada por cultivos de milho e fumo, ou seja, locais secos nos quais o curso d'água não atingia o cume da elevação onde se encontrava a ocupação (conforme o relevo do local, figura 1).

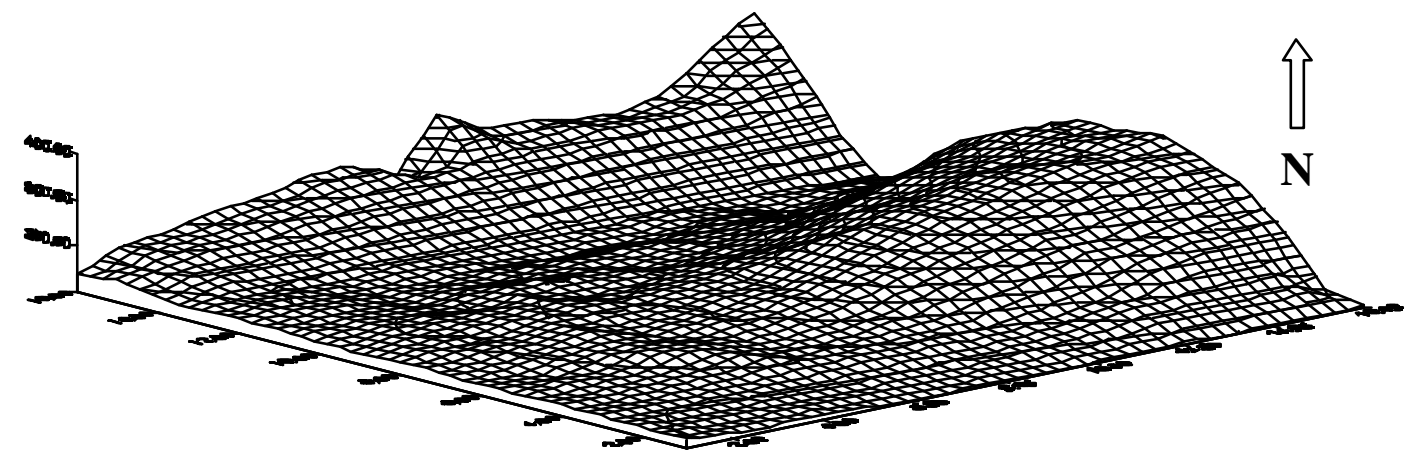

Figura 1 - Relevo do local: curvas de nível do sítio \$\$-JC-57, sítio Wilmoth Röpke. As divisões são de um metro (cem centímetros). Projeção vista sul em direção ao norte.

\subsubsection{Contextualização estratigráfica}

O sítio estudado foi um dos raros sítios atribuídos aos Guaranis que apresentava uma total ausência de perturbações por ação agrícola contemporânea, uma vez que a camada de ocupação encontrava-se a mais de sessenta centímetros de profundidade. Considerando que os arados de tração animal e mecânica atingem a subsuperfície em até cinqüenta centímetros (mais usualmente até trinta centímetros), as perturbações verificadas podem ser atribuídas aos processos pós-depocisionais, mas não as atividades contemporâneas. 
As camadas superficiais, ao contrário, sofreram com mais de 180 anos de aração contínuas, permitindo aos arqueólogos que atuaram no local, anteriores a este salvamento, considerassem o sítio destruído.

A margem esquerda do médio Jacuí possui neste trecho, uma várzea de aproximadamente 1.500 metros de largura e 6.000 metros de extensão. A margem oposta tangencia as encostas de basalto, fazendo com que a carga sedimentar seja depositada ao longo desta planície de inundação. Os depósitos neste ponto apresentam uma possança superior a 12 metros de espessura e são claramente pleisto-holocênicas.

As várias camadas que se sucedem nos perfis mostram depósitos que se alternam, revelando o ambienta deposicional pretérito. Nenhuma camada apresenta carbonatação ou conglomerados, com exceção dos níveis mais profundos onde os conglomerados de areia grossa, seixos e matacões se confundem com a carga do canal.

Os sedimentos transicionam em sequiências granudecrescentes e granucrescentes, ora contêm predominância de areia, ora de argila e, em alguns casos, aparecendo silte. Muito embora o rio Jacuí seja um rio tipicamente de serra, extremamente lótico, os depósitos que recobriram o sítio revelam momentos de cheias prolongadas (argilas) e outras cheias rápidas tipicamente torrenciais (areias). Devido a uma acentuada curva, distante 2.000 metros do sítio, o rio naturalmente foi represado em tempos de cheias possibilitando, assim, depósitos mais regulares e espessos na planície de inundação.

Como o sítio está localizado em uma planície de inundação, foi possível observar, conforme Milder (2000), que uma grande carga sedimentar, proveniente das encostas de basalto, foi depositada ao longo da várzea do rio. As várias camadas que se sucedem nos perfis do talude do rio contêm depósitos antropogênicos e não-antropogênicos que se alternam revelando o ambiente deposicional pretérito. Não foi identificada nenhuma camada que apresentasse carbonatação ou conglomerados, com exceção dos níveis mais profundos, onde os conglomerados de areia grossa, os seixos e os matacões se confundem com a carga do canal Milder e Soares (2002, não publicado), assim descrevem o perfil encontrado no talude próximo ao sítio:

Os sedimentos transicionam em seqüências granudecrescentes e granucrescentes, ora contém predominância de areia, ora de argila e, em alguns casos, aparece silte. Muito embora o rio Jacuí seja um rio tipicamente de serra, extremamente lótico, os depósitos que recobriram o sítio revelam momentos de cheias prolongadas (argilas) e outros de cheias rápidas tipicamente torrenciais (areias). Devido a uma acentuada curva distante 2.000 metros do sítio, o rio naturalmente foi represado em tempos de cheias possibilitando assim depósitos mais regulares e espessos na planície de inundação(...). Os depósitos litoestratigráficos apresentavam formas 
planares, porém, nitidamente com tendência a terem forma de cunha, devido ao forte encaixe do vale. Os depósitos antropogênicos nitidamente recobriam verticalmente, mas não traspassavam as seqüências naturais horizontalmente. Ou seja, eram posteriores ao seqüenciamento natural dos depósitos. Uma exceção a isso são as camadas mais superiores (dentro da lógica da geologia são as mais recentes), onde sequiências naturais eram interpenetradas por depósitos antropogênicos, conferindo assim uma contemporaneidade a eles.

Em relação ao NSA, localizado na planície ("habitação"), pode-se observar partes de troncos de árvores ainda mantendo o seu sistema radicular. Essas antigas vegetações devem ter perturbado o registro arqueológico através de ações de uprooting (MILDER, 2000). No entanto, as ações pós-deposicionais foram levadas em conta, a fim de limitar equívocos interpretativos. Procurou-se, dessa maneira, considerar as variáveis de cunho natural que atuaram no registro arqueológico.

A identificação da litoestratigrafia foi realizada pelo Professor Saul Milder, que assim descreve o local:

A estratificação revelou-se muito tímida em todo o perímetro percorrido, a única constante era uma fácie lamítica que variava entre $30 \mathrm{e}$ $70 \mathrm{~cm}$ de possança. Ela somente se apresentava nas margens que eram providas de PI (planície de inundação). Como exemplo de sua ocorrência pode-se citar o sítio Menegassi. Inicialmente, pensou-se em uma camada de solo antropogênico, porém a hipótese foi descartada devida a sua longa persistência na área (MILDER e SOARES, 2002, não publicado).

Os cortes realizados no talude do rio apresentaram uma seqüência estratigráfica que se reproduzia na várzea, onde estavam localizados os NSA da área de descarte e de ocupação ${ }^{10}$ ("habitação"). Eis a seqüência:

- camada de solo agrícola atual;

- camada de solo subatual (onde se inserem a maioria dos sítios Guarani do vale);

- camada argilo-arenosa estéril;

- fácie lamítica (camada que encerrou o sítio Ropke);

- camada areno-argilosa estéril.

No último escalonamento realizado para evidenciação do perfil no talude, foi feita uma sondagem, na qual não foram evidenciadas lentes de solo antropogênico. Embora as lentes desaparecessem, a Fácie Lamítica mantinha-se como uma constante. Tal fato reforçava a idéia de que as lentes não correspondiam a um sítio com várias ocupações, mas a uma área de

${ }^{10}$ A "habitação" foi assim denominada pelas evidências cerâmicas, líticas, fogueiras e negativos de esteio 
descarte do local de ocupação. Na abertura das trincheiras, dentro da Fácie Lamítica, foi evidenciado o NSA já citado anteriormente.

Embora o NSA da várzea estivesse fora da ação do arado contemporâneo, diversas perturbações foram registradas no sítio, a saber:

- as perturbações de origem animal: os formigueiros e os animais fossadores como tatus, minhocas, vermes, coleópteros, insetos e vários outros;

- as perturbações de origem vegetal, como as raízes de árvores lenhosas, tuberosas e palmáceas, que alteram diferentemente o registro arqueológico;

- as perturbações de origem pedogênica, que merecem destaque (MILDER, 2002).

A escavação objetivou fazer o maior número de registros possíveis, que priorizassem a distribuição dos artefatos, dos ecofatos e, ainda, a determinação do processo pós-deposicional no sítio. Conforme já citado, o método aplicado para a localização do NSA foi o de superfícies amplas, através da localização do sítio por meio de trincheiras multidirecionais, como foi realizado. A partir da localização do NSA e da realização das trincheiras multidirecionais, pôde-se definir as áreas de escavação controlada (Anexo 1: Desenho 4). Para a realização de uma decapagem com controle planialtimétrico, dividiu-se a área em setores com dimensões variáveis (Anexo 1: Desenho 5).

Em virtude de diferentes equipes trabalharem em diferentes períodos, a divisão em setores facilitava a atuação nos diversos momentos, além de configurar uma área ampla de escavação sincrônica, contínua e controlada. Em contrapartida, as trincheiras realizadas anteriormente permitiam um olhar diacrônico ao longo de toda a escavação.

A escavação permitiu o resgate de mais de cinco mil artefatos, sendo dois mil novecentos e vinte e sete plotados individualmente nos setores. Este número ainda não representa a totalidade dos artefatos, visto que as concentrações de cerâmica ou de material lítico eram tombadas com o mesmo número de registro, no livro da escavação. Foram coletados, além do material lítico e cerâmico, ossos e restos vegetais que aguardam análise em detalhe. Além disso, foram registradas, em desenhos, as estratigrafias das áreas escavadas e do entorno do sítio.

A ação pós-deposicional foi observada no sítio através das perturbações de origem animal, como for migueiros; vegetal, como raízes de árvores contemporâneas ao sítio; e geoperturbações, como argiloturbação e pedoturbação que influenciaram na disposição original dos artefatos. 
Como já citado acima, a técnica utilizada na área do solo antropogênico da várzea obedeceu ao modelo francês de decapagem de superfícies amplas em micro-níveis naturais (Anexo 2: Foto 6 e 7). Este procedimento visava ao registro acurado que permitisse a associação espacial dos artefatos, pela plotagem bi-dimensional em cada setor, de forma que se pudessem observar os distintos espaços sociais e sua utilização dentro da perspectiva antropológica. Neste sentido, a evidenciação dos artefatos foi tão importante quanto a ausência destes, observada através de espaços vazios ${ }^{11}$ e negativos de esteio. A técnica utilizada, a decapagem, em níveis naturais, permite a reconstituição não só dos procedimentos realizados no sítio, mas também das perturbações ocorridas e do processo de abandono.

$\mathrm{Na}$ área de descarte, a técnica utilizada foi a de retirada dos núcleos de solo antropogênicos (em forma de lentes) e a coleta das evidências, como artefatos líticos, cerâmicos, restos de alimentação, além do próprio sedimento antropogênico. Por ter sido considerada a inexistência de um contexto arqueológico ou espacial no talude, é mister a coleta dos artefatos e dos biofatos; a busca dos utensílios; a procura de alguns "ingredientes" da dieta Guarani, sua sazonalidade, oferta local; as formas de uso, de abate e descarnamento, e, também, a densidade demográfic a, entre outras possibilidades futuras.

\subsection{O que foi considerado artefato: sedimentos, lítico, cerâmica, ossos, conchas, evidências negativas}

Para fins desta tese, utilizourse o conceito de artefato como qualquer evidência que indique a alteração humana sobre o ambiente. Esses artefatos estão classificados segundo a concepção de "testemunhos", conforme criado por Leroi-Gourhan (1972, p.322) e adaptado para o Brasil por Pallestrini (1975, p. 99). Embora a aplicação no Paranapanema seja um pouco diferente do proposto pelos franceses, cabe aqui citar como o termo testemunho possui uma concepção ampla e de que se trata:

Le term de témoin est pris comme synonime de vestige mais il sousentend une fonction plutôt qu'un état. Les témoins ont été classés sur trois degrés successifs. Au premier degré on a subdivisé em témoins minéraux., témoins vegetaux et témoins animaux (...)Au second degré, les témoins ont été classes de la maniére suivante: on a entendu par bruts lês éléments nom modifiés par l'homme, comme des graviers em situation naturelle, des rognons de sílex fluviatile sans traces d'utilisation, un os placé dans une

\footnotetext{
${ }^{11}$ Sobre a importância dos espaços vazios para a reconstituição dos usos sociais, ver Leroi-Gourhan e Brézillon (1966) e Pallestrini (1975).
} 
situation stratigraphique qui permet de l'atribuer à une periode ou l'homme n’occupait pás Pincevent. (...) Le troisième degré de subdivision intèresse la forme, l'état et la struturation. La definition de ces termes interviendra plus loin, ils répondent par exemple au cas d'un bloc, rubéfié par lê feu, dans une bordure de foyer.. Les témoins peuvent être consideres dans des proprietés particulières, comme témoins fugaces, témoins discrets, témoins encombrants ou témoins négatifs. (...) Les témoins fugaces sont les menus vestiges qui apparaissent au cours du décapage d'approche et dont la conservation en place entraînerait le blocage de la fouille. Ce sont par exemple les parcelles de ocre rouge, les parcelles de charbon, les esquilles d'os ou de silex de moins d'un centimetre de diamètre. (...) Les témoins négatifs sont d'une part les vides, d'autre part les deficiences dans certaines catégories de vestiges. Les vides peuvent correspondre aux larges surfaces qui séparent les unes des autres les unités d'habitation, (...) Ils peuvent correspondre aussi, a l'interieur des unités domestiques. ${ }^{12}$

Neste estudo de caso, utilizar-se-á os seguintes conceitos dos autores acima citados:

- testemunhos brutos: blocos de basalto e arenito friável, sem marcas de utilização, mas em contexto arqueológico específico;

- testemunhos modificados: blocos de basalto modificados pela ação do calor, delimitando fogueiras, fogos ou fornos;

- testemunhos manufaturados: materiais cerâmicos e líticos, alterados com objetivo de confecção de artefatos. Têm-se lascas, raspadores, percutores, machados, além das vasilhas de diferentes funções;

- testemunhos fugazes: representados, reste caso, por camadas de terra enegrecida pela atividade do fogo, fragmentos de terra calcinada, fragmentos de carvão e fragmentos de argila queimada;

\footnotetext{
12 "O termo testemunho é tido como sinônimo de vestígio, mas é subentendida uma função de preferência a um estado. Os testemunhos foram classificados sob três graus sucessivos. No primeiro grau subdividiu-se em testemunhos minerais, vegetais e animais. No segundo grau, os testemunhos foram classificados da seguinte maneira: entendeu-se por brutos os elementos não modificados pelo homem, como os cascalhos em situação natural, dos seixos de sílex fluviais sem traços de utilização, um osso existente em uma situação estratigráfica que permite atribuir um período ao qual o home m não ocupava Pincevent. O terceiro grau de subdivisão diz respeito a forma, estado ou a estruturação. A definição destes termos intervirá depois, eles respondem, por exemplo, ao caso de um bloco, queimado pelo fogo, na margem de uma fogueira. Os testemunhos podem ser considerados através de propriedades particulares, como testemunhos fugazes, testemunhos discretos, testemunhos aglomerados ou testemunhos negativos. Os testemunhos fugazes são os menores vestígios que aparecem ao longo da decapagem, de abordagem e de cuja conservação no local implica o bloqueio da escavação. É o caso, por exemplo, dos pedaços de ocre vermelho, pedaços de carvão, as esquilhas de osso ou de sílex de menos de $1 \mathrm{~cm}$ de diâmetro. Os testemunhos negativos são, por um lado, os vazios, de outro, as deficiências de certas categorias de vestígios. Os vazios podem corresponder as largas superfícies que separam as unidades de habitação, eles podem corresponder, também, ao interior das unidades domésticas."
} 
- testemunhos discretos: como resíduos de lascamento - representado por microlascas e estilhas - e pequenos blocos de hematita, utilizados como corante para pintura das vasilhas cerâmicas;

- testemunhos negativos: neste estudo, representado pela ausência de artefatos nas camadas arqueológicas, negativos resultantes de materiais perecíveis, mudanças na coloração do solo ou decomposição de matéria orgânica, como vegetais ou ossos animais.

Sendo assim, este item apresenta as análises realizadas nos seguintes artefatos: materiais líticos sem alteração, mas em contextos arqueológicos, artefatos líticos e cerâmicos (material lítico utilizado em qualquer estado de alteração/preparação, ou usado de forma bruta com sinais de uso; a cerâmica do ponto de vista social, através das diferentes formas e inferências sobre sua funcionalidade), sedimentos antropogênicos e não-antropogênicos, a fim de provar a gênese humana na formação da chamada "terra preta" ou "mancha preta"; ossos humanos e de animais, com sinais de uso ou não, para reconstrução da dieta ou ambiente do sítio; conchas como indicador temporal (datação), alimentação ou uso como pigmentos; as evidências negativas foram consideradas a partir de sua ausência, ou seja, diferenças na composição do solo como indicador da presença de esteios, ou ausência de artefatos em determinadas áreas que poderiam ser utilizadas como passagem ou dormitório.

Esses artefatos somente serão apresentados a partir de sua análise isolada, sendo que, no capítulo quatro, será demonstrada sua distribuição no espaço e respectiva interpretação. Sendo assim, pretende-se apresentar neste item o conjunto dos artefatos, sem relação com a totalidade e com outros testemunhos.

\subsubsection{Testemunhos brutos}

Os testemunhos brutos estão representados nesta tese pelos artefatos líticos que não sofreram ação humana, intencional ou não, mas sua distribuição no espaço indica a ação voluntária humana em deslocar estes elementos de seu local de origem até o sítio arqueológico. Os testemunhos brutos, conforme já citado, não apresentam sinais de modificação proposital ou decorrente de utilização para qualquer fim. Neste sentido, são considerados os blocos de basalto e arenito que não sofreram intervenção de qualquer espécie, mas apresenta-se em um espaço delimitado como pertencente ao sítio arqueológico. Isto quer dizer que, nesta abordagem, pedras que sofreram ação do fogo foram modificadas, mesmo que esta modificação não fosse intencional. No caso dos testemunhos brutos, sua presença indica apenas que estes objetos foram levados intencionalmente para o sítio. 
Os diferentes testemunhos brutos serão apresentados de acordo com a matéria-prima. No entanto, esta separação é meramente funcional, com o objetivo de expor item por item dos elementos que compõem o sítio.

Foram considerados testemunhos brutos sete blocos de basalto encontrados na escavação que não apresentaram evidências de ação do fogo, lascamento intencional ou outra ação. Os blocos de basalto sem alterações estão próximos a locais de grande concentração de manchas escuras, sendo estas provavelmente resultantes de ação do fogo em fogueiras. Ao contrário dos blocos que sofreram ação direta do fogo, estes blocos estão em seu estado natural, partidos ou intactos, talvez com uma utilização que não deixou vestígios passíveis de registro.

Ainda de basalto, foram registrados 239 seixos de basalto, de tamanhos variados, de 1 a $13 \mathrm{~cm}$. Esses seixos rolados de rio não apresentam, em forma evidente, ação humana. Em um primeiro momento, foram classificados como testemunhos manufaturados (polidores), porém, em comparação com seixos rolados de rio obtidos em cascalheiras, não foi possível observar diferenças significativas. O polimento observado nos seixos da cascalheira do rio e do sítio não apresenta nenhuma diferença sob aumento de até sessenta vezes (60x) em lupa binocular. A dimensão, a forma, o peso e o polimento dos seixos encontrados na escavação são similares aos coletados aleatoriamente em uma cascalheira natural de um rio da região. Sendo assim, optou-se por classificar estes seixos como testemunhos brutos, uma vez que não apresentam sinais de modificação ou manufatura. Com isso, não se está afirmando que estes seixos não foram utilizados; ao contrário, é provável que estes seixos de basalto pudessem ser utilizados para o polimento interno das cerâmicas, haja vista alguns fragmentos de vasilhas possuírem polimento semehante ao brunhido. Porém, não se pode afirmar, igualmente, que o polimento desses seixos deve-se à ação humana de polir (Anexo 3: Foto 7).

Foram resgatados 210 blocos de arenito friável. Acredita-se que sejam "estoques" de matéria-prima para a confecção de calibradores, existentes e distribuídos em diversos locais tanto do NSA como na área de descarte, uma vez que estes afiadores em canaleta estão distribuídos em todo o sítio, conforme será visto adiante. Da mesma forma, estes blocos de arenito sem utilização poderiam ser acumulados para a confecção de alisadores e polidores, presentes em diversas dimensões no sítio. Os blocos de arenito estão geralmente quebrados, sem nenhuma face polida ou córtex que poderia indicar manufatura ou origem de seixo rolado de rio. Tem dimensões em geral pequenas, não ultrapassando $10 \mathrm{~cm}$ em seu maior comprimento (ver distribuição dos testemunhos brutos no Anexo 4: Gráficos 6, 7, 8, e 9). 


\subsubsection{Testemunhos modificados}

O basalto incluído nesta categoria apresenta fraturas térmicas, advindas do uso diretamente sobre o fogo. Neste sentido, as peças em questão poderiam ser utilizadas como suporte ou como condutoras de calor, denominadas como termóforas ${ }^{13}$ (Anexo 3: Foto 1). São 147 pedaços grandes de basalto decorticados por ação do fogo, além de outras centenas de pequenas lascas e estilhas termóforas. Embora não tenha sido encontrada nenhuma fogueira delimitada por pedras, como nos sítios do rio Paranapanema paulista (PALLESTRINI, 1975), uma cavidade localizada no setor 1 (Anexo 2: Fotos 9 e 10) apresenta características que permitem classificá-lo como uma área de combustão com depressão (talvez um forno?) ou uma fogueira em depressão. Alguns elementos corroboram esta idéia:

- no local foram encontrados diversos restos faunísticos, que talvez pudessem indicar um local para assar pequenos animais;

- a cavidade é mais profunda que larga, o que indica um buraco, ao qual dificilmente poderia ter sido utilizado como fogueira de cocção por cozimento através da cerâmica;

- concentração de basalto como matéria -prima, da qual não se encontram artefatos;

- não se encontram fragmentos de cerâmica dentro da cavidade.

É interessante apresentar, aqui, a definição de estrutura de combustão, proposta por Leri-Gourhan (1979, p. 9):

souvent désignées comme des 'foyers', ces structures se rapportent normalement à des objects aussi différents que le foyer lui-même (typologie à définir), les produits de vidange de foyers, la nappe de diffusion est plus large comme sens qu'aire de combustion qui doit être réservé pour désigner la zone effective souvent rubéfiée d'un foyer à même le sol (foyer à plat). ${ }^{14}$

Neste ponto, propõe-se distinguir as áreas com função de fogueira, fogos e fogões. A fogueira é o local onde se realizam fogos de maior extensão, podendo ser utilizada para cocção ou não, ou como área para lascamento. Igualmente, os fogões estariam relacionados à função cozinhar, com presença de cerâmica em seu interior e dimensões proporcionais ao número de recipientes utilizados. Os fogos, pelo contrário, estariam associados à função aquecer e não apresentariam cerâmica ou lítico em seu interior, e seu número seria

\footnotetext{
${ }^{13}$ Schmitz et al. (1990, p. 16) utilizam o termo 'pedras de fogão' para aquelas utilizadas sobre o fogo ou como condutoras de calor.

14 “Geralmente designados como 'fogos', estas estruturas se relacionam normalmente aos objetos tão diferentes como o fogão propriamente dito (tipologia a definir), os produtos de esvaziamento do fogo, a área (literalmente, toalha de mesa) de difusão é maior como sentido que a superfície de combustão que deve ser reservada para designar a zona efetiva queimada de um fogo no chão (fogo natural)."
} 
proporcional aos ocupantes da habitação. Os fogos têm dimensão reduzida, com pouca extensão espacial e pouca espessura. Acredita-se que a funcionalidade da área de combustão pode ser o critério classificatório para os termos fogueira, fogos ou fogão, a partir da extensão, espessura e presença de artefatos/biofatos nestas estruturas.

A bibliografia arqueológica Guarani referenda a existência de fogueiras rasas (com camada horizontal até $10 \mathrm{~cm}$ de espessura) ou, segundo Chmyz (1983, p.75), com "depressão côncava" (aparentemente escavada, com profundidade de até $60 \mathrm{~cm}$ ). Neste sentido, este ponto difere das fogueiras existentes no restante da habitação.

As outras fogueiras encontradas no espaço de habitação são semelhantes àquelas encontradas nas casas escavadas no rio Paranapanema paulista, que poderiam ser caracterizadas como fogueira interna que são "representadas por acúmulos de cinzas, carvão e terra queimada, com cerâmica ou indústria lítica em seu interior, sem pedras envolventes" (PALLESTRINI, 1975, p. 102) (Anexo 2: Fotos 7, 11 e 12).

As termóforas têm, ainda, sua distribuição associada às fogueiras, como pedras de suporte ou talvez utilizada como bigorna nos processos de lascamento bipolar. As peças de basalto não apresentam sinais de terem sido utilizadas como apoio para lascamento de outras peças, porém, esta afirmação é limitada uma vez que algumas peças estão decorticadas por ação do fogo, o que pode ter "apagado" os sinais de utilização.

Da mesma forma, pode-se descrever o glabro, que é um tipo de basalto com nódulos ou falhas, nos quais se incrustaram outros minerais. São 177 fragmentos de diversos tamanhos, igualmente associados às fogueiras e aos fogões. Por causa de sua constituição, o glabro quebra-se de forma irregular, sendo praticamente impossível distinguir a quebra por ação do fogo daquela realizada por ação humana. Uma vez que não existem testemunhos manufaturados de glabro, e tampouco se pode observar lascamentos intencionais no mesmo, este foi incluído nos testemunhos modificados (ver Anexo 4: Gráficos 12 e 13). Assim, o glabro foi considerado da mesma forma que o basalto, como pedra termófora ou pedra de suporte, sem alteração proposital humana.

\subsubsection{Testemunhos manufaturados}

Neste item, devem-se destacar os elementos mais abundantes que apresentam alteração visível do seu estado natural, que foram utilizados pela sociedade pretérita que ocupou o sítio, o lítico e a cerâmica. 
Uma vez que a análise desenvolvida nesta tese não prima pela classificação funcional dos artefatos, mas pela análise de seus possíveis usos, continuar-se-á a descrever os testemunhos manufaturados segundo a matéria-prima, apontando os possíveis usos nos casos em que estes possam ser definidos ou apontados.

A calcedônia é a matéria-prima mais utilizada no sítio. Uma vez que o seu processo de lascamento é passível de inferência, descrever-se-á a provável forma como os habitantes deste sítio utilizaram a calcedônia.

Em primeiro lugar, os blocos de calcedônia estão a disposição na beira do rio, a menos de $50 \mathrm{~m}$ de distância (ver Anexo 2: Desenho 4). Escolhidos os blocos, parece que estes eram colocados sob ação do fogo ou calor para facilitar ou modificar a estrutura cristalina da calcedônia. A ação de submeter blocos de calcedônia para posterior quebra e confecções de artefatos líticos e cerâmicos seriam realizadas em fogueiras. Uma vez que os núcleos de calcedônia apresentam-se aquecidos e lascados nas mesmas áreas de fogueira, acredita-se que algumas das peças em basalto poderiam ter sido utilizadas como ponto de apoio para o lascamento desses núcleos. Assim, percebem-se diversos núcleos (dos quais alguns foram remontados) que apresentam sinal de ação do fogo. São 28 conjuntos (138 peças) que podem ser associados a diferentes núcleos (Anexo 3: Fotos 2, 3, 4, e 5, sendo que o núcleo 3 encontra-se no setor 1 e os outros nos setores III a VI).

Além disso, existem 529 lascas, estilhas e detritos causados pelo fogo, sem nenhuma utilização, mas resultado da ação de aquecimento intencional destes núcleos. $\mathrm{O}$ número elevado destas peças deve-se à forma como a calcedônia se parte após uma longa exposição ao calor. Observando-se a forma das lascas obtidas a partir das fraturas térmicas e as outras lascas realizadas por percussão, pode-se inferir que o objetivo seria a realização de peças sobre lascas e lâminas, embora somente dois artefatos desta natureza tenham sido encontrados no sítio.

Ainda assim, observa-se que os núcleos, mesmo tendo sido aquecidos e tentativamente lascados, foram abandonados nos mesmos locais do lascamento, próximo à fogueira (ver Anexo 4: Gráficos 18, 19, 20 e 21). O procedimento realizado pelos Guaranis parece assemelhar-se ao descrito por Leroi-Gourhan e Brézillon (1966, p. 327) sobre o artesão "testar" a matéria-prima: "a maior parte dos cascalhos (rognons) têm os sinais de um ou dois golpes de percutor que tiveram, verdadeiramente, servido para experimentar a qualidade". Desta forma, embora a quantidade de núcleos e lascas de calcedônia sejam significativas, não representam artefatos em confecção, mas, muito provavelmente, o abandono de peças que não tiveram sua "qualidade" aprovada. 
A calcedônia queimada encontrada na habitação concentra-se próxima a um local de acúmulo de cinzas, restos orgânicos e blocos de basalto partidos pela ação do fogo (ver Anexo 4: Gráficos 22 e 23). No setor 1, este local se apresentava como uma depressão com a presença de carvões e ossos de animais. Embora se assemelhasse a descrição de "fogueira" utilizada por Pallestrini (1975, p. 102), acredita-se, por causa de sua profundidade, que se trata de uma fogueira em depressão (ou, talvez, um forno de cocção?, ver Anexo 2: Fotos 9 e 10). Dos 28 conjuntos que podem ser classific ados como núcleos, quatro foram retirados das proximidades desta fogueira. É interessante observar que destes quatro núcleos remontados não foi utilizada nenhuma lasca.

Os núcleos remontados (doravante denominados núcleos 3, 4, 5 e 6) possuem diversos pontos de percussão, demonstrando que o aquecimento destas peças foi proposital, embora nenhuma das lascas tivesse sido aproveitada (ver Anexo 3:Foto 3). A princípio, acredita-se que o aquecimento de tais peças foi demasiado, não atendendo às necessidades do lascador, pois foram abandonados no local de preparação dos mesmos.

Existem ainda 291 peças, lascas de calcedônia, que não apresentam sinal de fogo, mas certamente faziam parte dos núcleos encontrados no local da escavação. São lascas unipolares, estilhas e detritos, dos quais não se observam sinais de retoque ou uso. São conseqüências, provavelmente, dos mesmos núcleos supracitados, mas que não apresentam sinais de alteração pelo calor. Estas lascas de preparação de implemento compõem a maior parte do conjunto lítico do sítio em questão. Uma vez que o objetivo deste trabalho não é realizar percentagens sobre aproveitamento ou descarte de material, não será apresentada a quantificação destas peças em tabelas, pois são produtos da tentativa ou preparação de poucos artefatos utilizados, como será visto a seguir (a distribuição das lascas sem sinais de queima encontra-se no Anexo 4: Gráficos 24 e 25).

No mesmo conjunto, observam-se as lascas corticais de calcedônia. São 124 com sinais de ação do fogo e 172 sem sinais de aquecimento. Se, a primeira vista, o conjunto de peças trabalhadas é significativo em um sítio Guarani, por outro lado relembra-se o fato de que, deste total de testemunhos manufaturados, somente poucas lascas realmente apresentam algum sinal de utilização. No caso da calcedônia, apenas uma lasca de pequenas dimensões apresenta sinal de uso (Anexo 3: Foto 6).

As peças em arenito podem ser separadas em dois grandes grupos: aquelas que apresentam sinais de polimento (polidores?) e os afiadores em canaleta (Anexo 3: Foto 8). Os arenitos com sinal de polimento possuem diversas dimensões e formas, e a interpretação de seu uso fica restrita, uma vez que existem apenas duas peças que sofreram ação de polimento 
evidente, que são fragmentos de lâminas (de machado?) de basalto (Anexo 3: Foto 6). No sítio de Candelária, Schmitz et al. (1990, p. 26) relatam que existe a mesma diferença entre o grande número de polidores e a escassa quantidade de lâminas ou artefatos polidos dentro das residências. Ao mesmo tempo, as dimensões dessas peças com sinal de polimento variam em peso e forma, sendo os mais usuais pequenos 'seixos' elipsóides bastante polidos (16 peças). Ainda há pequenos blocos de arenito com uma ou mais superfícies apresentando polimento (110 peças), mas que, em virtude das fraturas dos blocos, torna-se difícil afirmar se estes polimentos são naturais ou consequiência da ação de polir. $\mathrm{O}$ polimento destas peças deu-se por abrasão, não sendo possível identificar, através de exame com lupa binocular com aumento de sessenta vezes, se a superfície do arenito foi friccionada contra material mais duro ou não (ver Anexo 3: Foto 8 e Anexo 4: Gráficos 16 e 17).

É importante questionar se os seixos de arenito que apresentam toda superfície polida são resultado de ação natural ou antrópica. É certo que se deve classificar o conjunto de seixos de arenito polido como testemunhos, uma vez que houve a remoção dos seixos do rio para o local da habitação. Por outro lado, pode-se questionar se estes seixos que apresentam polimento são reflexos ou não da ação humana de polir. A análise em lupa binocular com aumento de sessenta vezes (60x) não apresentou diferenças entre os seixos de arenito polidas e as lâminas de basalto, resguardadas a matéria-prima.

Uma vez que houve a dúvida em relação ao polimento dos seixos de arenito e a forma que estes apresentavam, buscou-se material para comparação entre os seixos de arenito polidos por ação natural (em cascalheiras de rio) e aqueles coletados no sítio arqueológico. Através da coleta de diversos seixos rolados, depositados em cascalheiras de rio, observou-se, em laboratório, que os seixos de arenito oriundos da escavação apresentam suas faces polidas e são, em forma, dimensão e desgaste, semelhantes a seixos rolados naturais. A comparação entre os artefatos e os seixos naturais, através da lupa binocular, não apresentou nenhuma diferença em qualquer uma das matérias-primas coletadas (calcedônia, basalto, arenito friável e silicificado). O polimento obtido pela ação das águas e da areia do rio deixou impressos os mesmos polimentos, não sendo possível observar sinais de uso marcantes nas peças coletadas durante a escavação (Anexo 3: Fotos 7 e 8).

Não se está afirmando que estas peças não tenham sido utilizadas para polir superfícies; apenas salienta-se que, em face da proximidade do rio e da ação deste sobre os seixos naturais, é praticamente impossível determinar qual dos seixos foi utilizado com esta função. Sendo assim, a determinação da função de 'polidor', no sítio em questão, deve ser 
visto com reserva, haja vista a semelhança com testemunhos brutos naturais, sem qualquer intervenção humana.

Em contrapartida, os dois fragmentos de artefatos polidos, de basalto, em muito se assemelham a "lâminas de machado" polido, conforme é citado na bibliografia arqueológica Guarani. $^{15}$ Neste estudo de caso, as duas peças que apresentam polimento evidente, por estarem quebradas, não apresentam as extremidades, portanto estão sem evidências de gume ou encabamento. No entanto, o polimento registrado nestes artefatos evidencia claramente a ação intencional, mantendo-se a dúvida sobre o uso das referidas peças (Anexo 3: Foto 6).

Outro caso é os blocos de arenito que apresentam uma ou mais superfícies polidas. Trata-se de 110 peças de dimensões variadas que apresentam alguma das superfícies mais polida que as demais. Não se pode afirmar que estas peças não sejam seixos maiores quebrados de rio e, portanto, também não foram antropicamente manipulados para estarem polidos. Por outro lado, a recíproca é verdadeira, pois a análise do polimento destas peças pode ter sido causado tanto pela ação do rolamento no rio como em virtude de algum desgaste por abrasão. $\mathrm{O}$ polimento, em observação na lupa binocular, não permite estabelecer diferenças entre peças naturais oriundas de cascalheiras e aquelas escavadas no sítio (Anexo 3: Fotos 7 e 8$)$.

Em contrapartida, os afiadores em canaleta (quarenta e uma peças) com uma única exceção são de arenito (apenas um exemplar foi feito sobre um fragmento de cerâmica) (Anexo 3: Foto 8). Apresentam de um a cinco sulcos, com extensão variável, mas profundidade ao redor de meio centímetro. A utilização destes afiadores é reconhecida em praticamente todos os sítios arqueológicos atribuídos aos antepassados dos Guaranis, sendo possível acreditar que os artefatos daí produzidos sejam cilíndricos em pedra, osso ou madeira. A presença relativamente abundante de restos de caça na área de descarte e na área de habitação pode indicar que o uso dos afiadores deve-se a confecção de artefatos com ponta (pontas de flecha?) ou outro material perfurante, sem descartar a possibilidade dos adornos (embora não tenha sido encontrado nenhum adorno tipo "tembetá" no local da escavação ou na área de descarte).

Ao mesmo tempo, arpões, azagaias ou partes das armadilhas de caça deveriam conter pontas que justificassem o elevado número de afiadores em canaleta. Um exemplo é o material coletado por Ribeiro (1996) na área de descarte (por ele denominado sítio RS-JC-56), no qual existem pontas lanceoladas de osso com sinal de alisamento (p.34) e fragmentos de

\footnotetext{
${ }^{15}$ Para lâminas de Machado em sítios Guaranis, ver De Masi e Schmitz (1987).
} 
tembetá polidos (p.30), todas as peças com diâmetro inferior a um centímetro, que poderiam ter sido alisados nos afiadores. Ao mesmo tempo, no sítio 02 do mapa da área (Anexo 1: Mapa 3) foi encontrado um tembetá de cristal de rocha polido, com um centímetro de diâmetro.

Deve-se observar ainda que os afiadores em canaleta, sem exceção, estão sobre pequenos blocos, sem córtex natural, e, em alguns casos, utilizados em todos os lados do poliedro. Considerando que o comprimento máximo das canaletas não ultrapassa seis centímetros, pode-se acreditar que, ou as peças possuíam este comprimento, ou, ao contrário, os afiadores eram movimentados na superfície a ser desgastada. Desta maneira, a extensão dos materiais abrasada pelos afiadores poderia ter diversos decímetros de comprimento. A ausência de peças em pedra polida com estas dimensões no sítio (comprimento variável, mas um centímetro de diâmetro) pode sugerir que o trabalho preponderante era sobre madeira, ossos ou outro material perecível, não descartando o uso sobre rochas (distribuição dos afiadores em canaleta no Anexo 4: Gráficos 14 e 15).

Já o arenito silicificado apresenta um número bem menor de exemplares, reduzindo-se a três lascas, três detritos, três lascas corticais e três estilhas de lascamento. As lascas são unipolares e não apresentam sinal de uso. Podem ser enquadradas como lascas de preparação de artefatos, embora não tenha sido encontrada nenhuma peça utilizada.

A única lasca de calcedônia com sinais de utilização foi lascada de forma unipolar, com desgaste distal como um gume. É o mesmo caso da lasca retocada de riolito, que apresenta lascamento unipolar, retoques ao longo do bordo lateral. Estas são as únicas duas peças lascadas com sinal de uso no śtio (Anexo 3: Foto 6). O riolito apresenta também uma lasca de preparação.

O cristal de rocha ou quartzo é composto por um conjunto de 24 peças, sem sinais de uso, de dimensões reduzidas. O lascamento do quartzo parece ter sido bipolar, mas a dimensão das peças não permite afirmar. São, na maioria, detritos de lascamento dos quais não foram localizados os núcleos.

Outro fator interessante deve ser apontado: existem poucos testemunhos líticos manufaturados "acabados", excetuando-se as lascas de calcedônia e riolito e os afiadores, dentro da área de habitação. A partir deste elemento, somado a outros que serão apresentados ao longo da tese, sugere-se que o espaço escavado refere-se a uma habitação ou casa, com a função de moradia permanente. Caso o local fosse utilizado como um abrigo com funções temporárias (acampamento de caça ou "casa de roça"), os artefatos presentes apontariam nesta direção; no entanto, não há artefatos pesados (como talhadores, picões ou outros, que seriam utilizados em um local de preparo e/ou cultivo do solo) nem artefatos retocados (como lascas, 
furadores ou outros que poderiam ser atribuídos ao abate e descarnamento de animais de porte). A ausência desses elementos contribui para que a denominação "habitação" refira-se a um local de uso continuado como moradia, respaldado ainda pelos testemunhos cerâmicos, como será visto a seguir.

\subsubsection{Cerâmica}

A cerâmica, segundo a Terminologia (1976), consiste em "artesanato de barro queimado, com forma específica, como vasilhas ou potes". Porém, ao contrário do conceito de decoração tratada na mesma obra, acredita-se que se pode dividir tratamento de superfície de decoração. Na Terminologia (1976, p.129), decoração plástica é "qualquer técnica de decoração que implica em modificações da superfície da cerâmica: corrugada, escovada, aplicada etc." O tratamento de superfície ou acabamento pode substituir o termo decoração, conforme adotado por Brochado e La Salvia (1989, p. 111 et seq.). Desta forma, corrugado não pode ser considerado decoração, pois se trata de técnica de confecção por roletes, sem trabalho posterior. Em contrapartida, os outros elementos presentes na superfície cerâmica Guarani (ungulado, escovado, pintado e liso) são elaborados a partir da junção de roletes um após outro, que configura o corrugado (Anexo 3: Foto 9). A cerâmica será abordada em duas perspectivas: a primeira, com base na funcionalidade das vasilhas a partir do perfil das bordas, conforme Brochado e La Salvia (1989), Brochado, Monticelli e Neuman (1990) e Brochado e Monticelli (1994); a segunda, no capítulo quatro, da distribuição dos fragmentos no espaço e sua interpretação. Não serão utilizadas nesta abordagem as denominações Guaranis históricas para os tipos de vasilhas registradas no sítio, por se adotar o critério funcional na descrição delas.

Os fragmentos de cerâmica presentes no sítio enquadramse na classificação do binômio forma/função (panela, caçarola ou tigela, talha, tigela de beber, prato) e tratamento de superfície (corrugado, corrugado-ungulado, ungulado, liso e pintado) conhecidos em todos os sítios Guaranis. As outras categorias funcionais descritas por Brochado (BROCHADO, MONTICELLI e NEUMANN, 1990; BROCHADO e MONTICELLI, 1994), como o tostador, não foram encontradas no sítio arqueológico em questão. Nos outros sítios do Estado do Rio Grande do Sul que tiveram escavação sistemática, tampouco aparece este tipo de vasilha (SCHMITZ et al, 1990; CARLE, 2002).

A reconstrução da funcionalidade parte dos pressupostos de Brochado, Monticelli e Neumann (1990, p. 727), como segue: 
São utilizados basicamente os fragmentos de bordas da vasilha...Os fragmentos de borda são desenhados de perfil, na posição que deveriam ocupar na vasilha, quando vista lateralmente. Para se reconstruir esta posição, as bordas são orientadas apoiando o arco da boca sobre uma superfície plana ou procurando orientá-lo de maneira que fique visivelmente em um mesmo plano. Isto parte do pressuposto de que o plano da boca das vasilhas se encontra em posição relativamente horizontal quando estas se encontram em posição de uso (...). Os perfis de borda estão usualmente orientados com o lado externo da vasilha à direita, de maneira que o eixo imaginário de seu centro se encontra à esquerda.

Sendo assim, as Fotografias das bordas de vasilhas seguem este procedimento, estando colocadas em posição vertical, separadas por tratamento de superfície (ou acabamento) e função, em que, sobre cada fragmento, está colocado o diâmetro de boca aproximado, conforme um ábaco de círculos concêntricos, considerando que a boca das vasilhas são circulares e, mais raramente, ovaladas. As bordas foram fotografadas considerando o plano de inclinação horizontal, mergulhadas na areia, de maneira que se possa observar o perfil, com o tratamento de superfície sempre do lado direito, de forma que pudesse ser reconstruída sua forma. Apresentam-se, abaixo, os motivos que levaram a não realizar tal reconstrução.

Deve-se abrir um parêntese na questão da cerâmica. Acredita-se que a ausência de fragmentos de tostadores em sítios meridionais escavados de forma sistemática e em áreas amplas contribui para a discussão do uso da farinha de mandioca amarga entre os Guaranis. No vale do Jacuí, ${ }^{16}$ não existe nenhum sítio com fragmentos de borda que pudesse ser associado à categoria tostador, de forma que, se utilizada e processada, a mandioca amarga deveria constituir um outro uso que não fosse a farinha. Sendo assim, uma vez que se está partindo somente do registro arqueológico, a hipótese de confecção de farinha de mandioca, a partir da existência de tostadores, é remota. ${ }^{17}$

Se consideradas, ainda, as condições do solo atual do vale do rio Jacuí, o cultivo de mandioca na região do sítio analisado é impossível, haja vista as baixas temperaturas no inverno, a baixa fertilidade e as características arenosas do solo que limitariam - a ponto de ser improdutivo - o cultivo da mandioca. ${ }^{18}$ No caso da várzea do rio Jacuí, em praticamente toda a sua extensão, a combinação de solos arenosos e úmidos, baixas temperaturas no

\footnotetext{
${ }^{16}$ Sérgio Klamt analisou o material lítico e cerâmico de 76 sítios arqueológicos Guaranis no vale do rio Jacuí, não encontrando fragmentos de vasilhas que pudessem ser classificadas como tostador. Comunicação pessoal, julho de 2003.

17 Outro detalhe importante é que a categoria tostador, conforme proposta por Brochado, é exclusivamente baseada nos dicionários de Montoya [1619] (1639), que realiza sua obra na região do baixo Paranapanema paranaense.

${ }^{18}$ Comunicação pessoal de Sérgio Klamt (julho de 2003), a partir dos resultados do Embrapa solos do município
} 
inverno e baixa concentração de matéria orgânica nas camadas superficiais do solo, inviabilizam o cultivo da mandioca, podendo esta ser plantada em outros locais, distantes da várzea.

Concluindo este parêntese, deve-se ter em conta que, na área da escavação no Setor III, foi encontrado um grão de milho carbonizado, que está em processo de análise. A mestre Patrícia Goulart Bustamante realiza seu doutoramento na Embrapa- sementes, do Rio de Janeiro, com análises de variedades de milho, a fim de propor a dispersão deste cultivo pelo País. Somado a este vestígio, fragmentos da planta (parte da raiz e do pé de milho) ampliam a possibilidade do cultivo do milho. Ainda se aguardam as análises dos fitólitos existentes no solo que contribuam para a determinação deste e de outros cultivares.

A análise do tratamento de superfície da cerâmica recaiu, neste trabalho, para os cinco mais recorrentes, uma vez que a multiplicação de elementos classificatórios em nada acrescentaria na análise deste trabalho. ${ }^{19}$ As classes de vasilhas aqui apresentadas seguirão a interpretação arqueológica, ou seja, a inferência de sua funcionalidade a partir da reconstituição do perfil da borda, diâmetro da boca e tratamento de superfície. Estes três elementos conjugados permitem inferir com maior precisão o uso de cada recipiente. No entanto, esta classificação não resolve o problema da classificação das vasilhas arqueológicas Guaranis, uma vez que as coleções depositadas em museus apresentam formas que não se enquadram em nenhum dos tipos aqui determinados (um exemplo encontra-se nas Fotos 10 e 11 do Anexo 3).

Existem algumas limitações nas regras práticas para a reconstrução gráfica da cerâmica Guarani, conforme proposto por Brochado, Monticelli e Neumann (1990) e Brochado e Monticelli (1994):

1. Algumas classes de vasilhas podem ser confundidas, como as panelas com forma de talha $^{20}$ (cambuchí com forma de yapepó), as talhas com forma de panela (yapepó com forma

de Sobradinho, no vale do rio Jacuí, RS.

19 Rogge (1996) classifica em 13 tipos diferentes o tratamento de superfície Corrugado. Brochado e La Salvia (1989) assim dividem os tratamentos de superfície: corrugados (nove tipos); dígito-ungulado (três); imbricado (três); ungulado (quinze); beliscado (dois); serrungulado (quatro); além de cinco outros tipos. O autor desta tese, em parceria com o prof. Sérgio Klamt, está confeccionando um guia das cerâmicas depositadas em instituições do Rio Grande do Sul. O que pode ser observado no primeiro momento é que as vasilhas inteiras apresentam diversos tipos de corrugados no mesmo recipiente, além de que, em alguns casos, pode-se verificar diferentes tratamentos de superfície na mesma vasilha (por exemplo, liso, corrugado e ungulado, ou corrugado e pintado, no mesmo vasilhame).

20 As panelas (yapepó) têm base conoidal e paredes infletidas, com bojo marcado e arredondado. Quando pintadas interna ou externamente, são classificadas como talhas (cambuchí). As talhas, ou jarros, são pintadas, de contorno complexo, com vários pontos de ângulo (BROCHADO, MONTICELLI e NEUMANN, 1990, p. 110113). Existem casos nos quais as panelas possuem carenas, ombros e inflexões, sendo, porém, corrugadas; ao mesmo tempo, existem talhas lisas que não possuem estes mesmos elementos, possuindo a forma de panelas. 
de cambuchi), bem como as tigelas com os pratos fundos. A determinação do uso, neste trabalho, será determinada pelo tratamento de superfície e pela forma, quando possíveis;

2. A relação estabelecida por Brochado, Monticelli e Neumann (1990), entre altura e diâmetro de boca, pode ser somente aplicada com certa segurança para as panelas, sendo que as tigelas de beber, as talhas e os pratos apresentam desvios padrão bastante alto para serem considerados como fidedignos. Ao mesmo tempo, em manuscrito não publicado, Jacobus ${ }^{21}$ demonstra que o tamanho das vasilhas deve ser determinado pela relação entre altura e diâmetro máximo, ou considerar a relação direta existente entre diâmetro de boca e diâmetro máximo. Em uma distribuição gráfica entre estes elementos, as dimensões do diâmetro de boca e diâmetro máximo possibilitam uma relação diretamente proporcional entre ambas; ${ }^{22}$

3. As regras práticas de Brochado e Monticelli (1994) partem de um conjunto depositado no Centro de Estudos e Pesquisas Arqueológicas da PUC-RS (CEPA-PUC), em um total de 125 vasilhas de diversos rios do Estado do RS, mas, sobretudo, o vale do rio Uruguai. Pode-se observar, em diversas instituições dentro do Estado do $\mathrm{RS}^{23}$ que existem nuances entre as coleções, que poderiam indicar estilos regionais, e a reconstituição das formas necessariamente deveria obedecer a estes regionalismos. Até o momento, verifica-se que existem variações dentro da mesma classe de vasilhas, o que somente será apurado no estudo em elaboração. ${ }^{24}$

Até o presente momento, foram consideradas as semelhanças entre as formas, mas nenhum estudo deteve-se para as variações espaciais ou temporais. A reconstrução de formas, como meio de determinar a funcionalidade, não somente é possível como deve ser constantemente perseguida. Acredita-se que uma contribuição à pesquisa arqueológica seria a produção de catálogos regionais com as formas das vasilhas depositadas em cada Estado, nas quais o número de vasilhas permita a catalogação de diversos exemplares com a mesma funcionalidade.

\footnotetext{
${ }^{21}$ Monografia de disciplina, incluída no acervo da biblioteca do prof. Brochado.

${ }^{22}$ Em trabalho não publicado, evidencia-se a mesma relação apresentada por Jacobus, a partir da coleção de vasilhas existentes no acervo do CEPA -PUCRS. Trabalho apresentado no III Congresso Internacional de Estudos Ibero-Americanos, PUCRS, Porto Alegre.

${ }^{23}$ Museu Antropológico Diretor Pestana (município de Ijuí), Museu de Ciência e Tecnologia da PUC, Museu Júlio de Castilhos, Universidade Federal do Rio Grande do Sul (em Porto Alegre), Museu do Colégio Mauá, Centro de Ensino e Pesquisas Arqueológicas - CEPA/UNISC (Santa Cruz do Sul), Museu Palotino, Museu Gama D’Eça, UFSM (em Santa Maria).

${ }^{24}$ As vasilhas são registradas gráfica e fotograficamente, sendo anotados os diâmetros de boca, diâmetro máximo e outros, em caso de vasilhas complexas. Da mesma forma, a altura dos diâmetros, tratamento de superfície, decoração, pintura e local de coleta. Este catálogo está em elaboração, o que permitirá definir regionalismos com relação às formas, a pintura e "formas exóticas" que não se enquadram em nenhuma categoria estabelecida.
} 
Considerando estes elementos é que a reconstituição das formas das vasilhas a partir dos fragmentos não foi realizada nesta tese (embora se pretenda realizar este trabalho em outra oportunidade), considerando que a classificação morfológica das vasilhas foi colocada nos cinco tipos conhecidos. Ademais, a reconstituição das vasilhas complexas, com inflexões, carenas e ombros passam mais pela criatividade do autor que da realidade dos conjuntos de formas existentes. Somente como exemplo, as coleções inteiras dos vales dos rios Ijuí e Piratini, no RS, apresentam diversas vasilhas com dupla cintura, reconhecida tanto nos registros históricos como arqueológicos. Porém, este tipo de vasilha dificilmente é reconstituído, dada a impossibilidade de visualização dos contornos a partir dos fragmentos de borda. Ao mesmo tempo, em coleções de vasilhas inteiras, a classificação é dificultada pela forma, uma vez que não se enquadram em nenhuma classificação existente (Anexo 3: Fotos 10 e 11).

Outro problema grave na reconstrução das vasilhas é o percentual que o fragmento da borda ocupa no perímetro total da vasilha. Considerando o perímetro total das vasilhas igual a $100 \%$, observa-se que as reconstruções de diâmetro de boca deveriam ser realizadas a partir de, no mínimo $12,5 \%$, o que corresponderia a $1 / 8$ de perímetro. O que se percebe neste estudo de caso é que, na maior parte dos casos, os fragmentos não correspondem a $1 / 8$ de perímetro total, o que implica na medição do diâmetro, que fica comprometida. Da mesma forma, como apresentado nas fotos citadas (Anexo 3: Fotos 10 e 11), somente um fragmento que apresentasse o perfil com uma parte da parede (bojo ou fundo) permitiria a reconstrução ideal das formas de panelas, talhas e tigelas de beber carenadas.

Ao mesmo tempo, a reconstituição segue, no mais das vezes, o capricho do pesquisador, haja vista que as vasilhas Guaranis possuem contornos tanto conoidais como arredondados, variando conforme classe, função e dimensão. Esta análise é melhor apresentada adiante, em relação as tigelas de beber, categoria que possui tanto os contornos arredondados como cônicos. Nesta proposta, acredita-se que o conjunto de vasilhas obtidas no sítio em questão aponta para certas regularidades que serão apresentadas a seguir.

Em um sentido amplo, as regras práticas estabelecidas por Brochado e Monticelli (1994) são válidas e devem ser perseguidas, mas um avanço crítico será estabelecido quando for dada a mesma importância à forma exótica quanto às comuns. Neste sentido, ao invés de uma crítica, busca-se realizar uma releitura para ampliar os elementos de análise dos dados arqueológicos. Um exemplo pode ser observado a partir das vasilhas consideradas panelas com tratamento de superfície corrugado. Nos sítios do Estado do RS, os percentuais obtidos durante a execução do PRONAPA estabeleceram a subtradição corrugada em virtude de, pelo 
menos, $50 \%$ dos fragmentos pertencerem a esta decoração. Em nenhum momento foi considerado que, em virtude do uso contínuo sobre o fogo, a mudança de local ou a durabilidade da cerâmica, aquilo que mais se usa, mais se quebra (LA SALVIA e BROCHADO, 1989, p.123). Tampouco foram consideradas as dimensões dos fragmentos, pois as grandes vasilhas quebram em fragmentos maiores que as pequenas, ao mesmo tempo em que, probabilisticamente, vasilhas de paredes finas quebram em mais fragmentos que as vasilhas de paredes espessas.

Acredita-se que uma proposta a ser lançada é um estudo métrico das vasilhas inteiras, através da medição da área da superfície de cada exemplar. Nas análises convencionais, a borda é reconstituída, oportunizando o diâmetro de boca e a função. Se, em uma coleção de vasilhas inteiras, medir-se a superfície que cada vasilha (mesma forma, mesma função, mesmo diâmetro de boca, mesma altura) possui, estabelecer-se-á a área plana da vasilha, em centímetros ou metros quadrados $\left(\mathrm{cm}^{2}\right.$ ou $\left.\mathrm{m}^{2}\right)$. Separando as bordas e definindo similaridades entre tratamento de superfície e espessura das paredes, é possível separar os fragmentos em áreas correspondentes a cada vasilha. Assim, mesmo com a ausência de bordas, pode-se inferir, aproximadamente, o número de vasilhas. Desta forma, a reconstrução do número de vasilhas presentes no sítio seria facilitado pela quantificação dos fragmentos totais de cada sítio.

Ao mesmo tempo, outras possibilidades de pesquisa devem ser perseguidas. Fajardo (2001, p.44-45) aponta que a análise química dos fragmentos de corrugado apresentam maior concentração de carbonato de cálcio $\left(\mathrm{CaCO}_{3}\right)$ que os fragmentos lisos. A partir disto, esse autor propõe que é possível comprovar quimicamente que as vasilhas corrugadas iam ao fogo e que, na evaporação, a água utilizada para cozinhar os elementos fixava o $\mathrm{CaCo}_{3}$ no interior da vasilha, ao contrário das vasilhas lisas.

Outra sugestão que deve ser perseguida é a comprovação funcional do corrugado enquanto tratamento de superfície proposital com objetivo definido. Embora tenha sido atribuído, muitas vezes, a "preguiça" da índia em alisar os roletes corrugados, acredita-se que a realização deste tratamento de superfície nas vasilhas que são utilizadas como processadoras de alimento (panelas e tigelas, sobretudo) devem-se à função cozinhar, no qual a forma (panela ou tigela), por meio da fervura e/ou cozimento, tem sua capacidade ampliada pelo tratamento de superfície. Com isso, quer-se dizer que o corrugado, através das vilosidades que compõem as dobras dos roletes, ampliam em várias vezes a absorção e manutenção do calor, 
diferentemente das vasilhas lisas, unguladas ou escovadas. ${ }^{25}$ Talvez isto também justifique o fato de que a maior frequiência de vasilhas corrugadas estejam na classificação panela ou tigela.

Da mesma forma, as decorações aparecem sobretudo naquelas vasilhas que a função é consumir ou guardar alimentos. Desta forma, a presença de ungulados, pintados e lisos estão ligadas, no sítio em questão, às tigelas de beber, pratos e talhas.

Uma última questão deve ser levantada nesta tese a respeito da cerâmica. Particularmente, o estudo das coleções de vasilhas cerâmicas inteiras até agora conhecidas e documentadas não permite o uso do atributo liso à cerâmica Guarani. Se este tratamento é comum a diversos fragmentos, deve-se atentar que, em formas inteiras, o liso está geralmente associado à pintura, como uma etapa de produção. Embora o número de vasilhas lisas em coleções seja significativo, o que se percebe é que as formas em que este tratamento aparece remete, quase sempre, a vasilhas com pintura. A análise das formas inteiras apresenta as vasilhas pintadas podendo ser acompanhadas dos outros tratamentos de superfície, como o corrugado, o corrugado-ungulado, o ungulado ou outro. Mas a predominância das vasilhas lisas possui, no seu interior, no terço ou metade superior, a decoração pintada. Se, por um lado, a contagem de fragmentos lisos pode ser significante em um sítio, por outro, pode-se estar referindo à parte inferior das vasilhas carenadas pintadas que, conhecidamente, não levam pintura.

Sendo assim, acredita-se que o fragmento liso pode referir-se ou à parte da vasilha que não recebeu pintura ou, por processos físicos, químicos ou procedimentos de laboratório, perderam a pintura.

Outras questões devem ser levantadas nesta tese. A decoração ungulada, no sítio em questão e nas coleções estudadas, está associada a vasilhas de pequenas dimensões ou como traço decorativo. As bordas unguladas faziam parte de vasilhas de dimensões inferiores a vinte centímetros de boca e, embora existam panelas com decoração ungulada, na maior parte das vezes esta decoração está associada a tigelas de beber. Nas vasilhas inteiras conhecidas pertencentes a outras coleções já catalogadas, o ungulado é utilizado como decoração que envolve a borda, podendo estar associada às outras decorações e ao tratamento de superfície

\footnotetext{
${ }^{25}$ Para fins deste trabalho, não foi considerado o escovado como tratamento de superfície, uma vez que este não se encontra presente no sítio em estudo. Outros tratamentos que não se enquadram nos cinco acima descritos foram quantificados como "inclassificáveis" por não atenderem ao objetivo do trabalho. Neste sentido, somente quatro fragmentos, que seriam classificados como "aplicados" (segundo LA SALVIA e BROCHADO, 1989) entraram nesta quantificação.
} 
corrugado. Adiante, ver-se-á como os distintos tratamentos de superfície podem ser associados às distintas funções.

Estabeleceurse um critério de análise a partir das formas associadas a tratamento de superfície e ao acabamento das mesmas. Sendo assim, neste trabalho não serão apresentadas percentagens ou tabelas que considerem a totalidade de fragmentos de cada tipo de superfície. A menor unidade será a vasilha (cf. proposto por GONZÁLEZ, 1996, p. 240), estabelecendo $a$ priori que cada fragmento de borda com os elementos da tríade diferentes (diâmetro de boca + função + superfície) representam uma vasilha e não somente um fragmento. Embora possa parecer perigoso, a separação das bordas revelou com facilidade aqueles que pertenceriam à mesma vasilha, seja por qualquer dos elementos da tríade semelhantes. Assim, não foi realizada a contagem da totalidade dos fragmentos de corpo pelos seguintes fatores:

- durabilidade: vasilhas mais usadas são mais substituídas, gerando mais fragmentos;

- dimensões: vasilhas grandes podem gerar mais fragmentos ou menos fragmentos de maiores dimensões. Por exemplo, pode-se ter ambas possibilidades: uma vasilha grande de paredes grossas quebrando-se em poucos fragmentos ou de parede média, em muitos fragmentos; da mesma forma, vasilhas pequenas quase sempre possuem paredes finas e quebram-se em muitos fragmentos. A contagem, em ambos os casos, são inúteis, enquanto não for associada à área plana da vasilha com a forma e o diâmetro de boca.

Sendo assim, mostra-se o resultado da análise das bordas, aqui consideradas como vasilhas (ou suas melhores representantes), das quais, a partir da tríade supracitada, condicionar-se-á esta análise.

\subsubsection{Panelas}

As panelas são "vasilhas usadas para a preparação de alimentos por fervura sobre o fogo" (BROCHADO e MONTICELLI, 1994, p.109), têm base conoidal ou arredondada, paredes infletidas, bojo marcado e borda côncava, vertical ou inclinada para fora. Nesta categoria existem 146 bordas de panelas, todas corrugadas, em uma associação direta entre preparação de alimentos e tratamento de superfície (Anexo 3: Fotos 12, 13, 14, 15 e 16). Deve-se salientar que a categoria "urna funerária" é uma "reciclagem" da vasilha, não existindo, no conjunto de vasilhas arqueológicas atribuídas aos antepassados dos Guaranis, nenhuma forma específica que tenha uso exclusivo como local de enterramento. As bordas de panelas registradas possuem dimensões que variam de 10 a $60 \mathrm{~cm}$ de diâmetro de boca. Considerando a maior e menor medidas registradas (10 e 60), a medida intermediária é $35 \mathrm{~cm}$,

o que pode ser atribuída como média aritmética deste conjunto. Porém, ao comparar-se a 
média aritmética com as medidas de diâmetro de boca, percebe-se que há poucos exemplares de bordas neste tamanho. Optou-se, assim, por considerar a média a partir da popularidade de cada diâmetro, ou seja, quais as medidas que aparecem mais na categoria funcional.

Sendo assim, acredita-se que uma classificação pertinente seria dividir o conjunto segundo a funcionalidade, dividindo as vasilhas nas dimensões pequenas (10 a $15 \mathrm{~cm}$ ), médias (16 a $28 \mathrm{~cm})$, grandes $(30$ a $50 \mathrm{~cm}$ ) e muito grandes (acima de $50 \mathrm{~cm}$, Gráfico 1). Novamente coloca-se que este critério de divisão é aleatório, mas que considera, sobretudo, a popularidade dos diâmetros encontrados (ver Anexo 6: Planilha 1). Considerou-se, além da funcionalidade e o diâmetro de boca das vasilhas, a realidade a partir das coleções inteiras para uma melhor distribuição das dimensões.

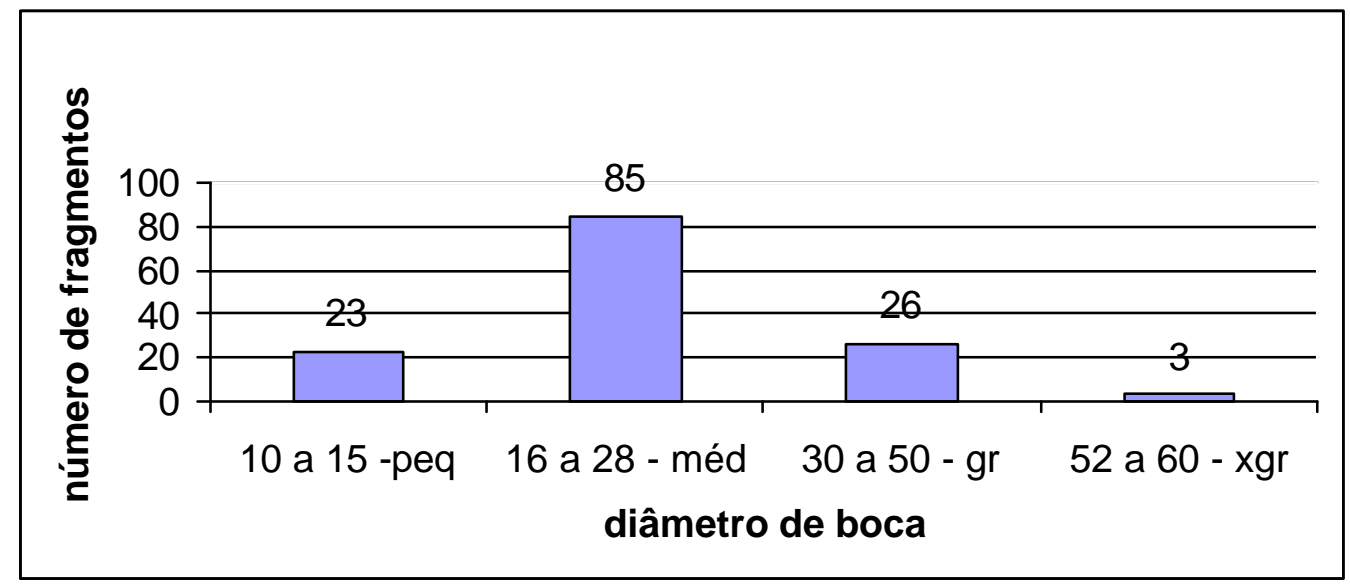

Gráfico 1- Bordas de panelas corrugadas considerando diâmetro de boca e número de fragmentos.

Como se pode observar, a maior quantidade de fragmentos de bordas é de tamanho médio, o que permite pensar que a habitação era composta por poucas famílias nucleares. Esta linha de pensamento surge na medida em que, considerando o espaço de habitação como local das refeições (pelo número de fragmentos cerâmicos presentes nas fogueiras), vasilhas de maiores dimensões seriam utilizadas para um número maior de pessoas e vice-versa. Esta linha de raciocínio é prontamente interrompida caso as refeições acontecessem fora do espaço doméstico, mas a área de escavação não permite nenhuma inferência neste sentido.

Embora, neste caso, tenha se realizado a colagem de diversos fragmentos de borda, pode-se acreditar que estes números não condizem com o número de vasilhas inteiras. Ainda assim, está-se frente a um número significativo de panelas, o que permite acreditar que o consumo de alimentos cozidos ou ensopados fosse cotidiano. Mesmo que sejam mudados os critérios (considerando o tamanho maior e menor, 10 e $60 \mathrm{~cm}$, a média entre os extremos seria 
$35 \mathrm{~cm}$; se fosse considerada média a medida de 25 a $45 \mathrm{~cm}$ ), os valores medianos não seriam a maioria das vasilhas.

Ao mesmo tempo, a quantidade de vasilhas médias, considerando que estes fragmentos referem-se ao local da escavação, permitem inferir que, no momento do abandono, o total de panelas era composto por um conjunto aproximado de três panelas médias para cada panela grande ou pequena (1:3:1). Esta proporção reforça a idéia de um grupo de pessoas que convivem em uma mesma habitação, hipoteticamente falando, talvez uma família extensa composta por duas ou três famílias nucleares (conforme se apresentará mais tarde, através da concentração de fogos, vasilhas e outros artefatos). Nesta tese, propõe-se que cada família nuclear poderia ser composta por quatro a seis pessoas, em virtude do total das vasilhas dentro de cada categoria funcional.

\subsubsection{Tige las ou caçarolas}

As tigelas ou caçarolas são vasilhas que "tinham uma forma tronco-cônica, com bordas diretas, contínuas com a parede, aproximadamente vertical ou inclinada para fora e base aplanada ou levemente arredondada" (BROCHADO e MONTICELLI, 1994, p.112). A borda poderia ser também levemente infletida, e sua função seria cozinhar alimentos por fervura sobre o fogo. A maioria das tigelas possui tratamento de superfície corrugado ou corrugadoungulado (Anexo 3: Fotos 17, 18 e 19).

Segundo Brochado e Monticelli (1994) o diâmetro de boca médio das caçarolas variam de 30 a $48 \mathrm{~cm}$. Neste caso, foram encontradas tigelas menores e maiores (de 8 a $66 \mathrm{~cm}$ ). Sendo assim, poder-se-ia também dividir as tigelas em muito pequenas $(8-10 \mathrm{~cm})$, pequenas (12 a $20 \mathrm{~cm}$ ), médias (22 a $34 \mathrm{~cm}$ ) e grandes (de 36 a $66 \mathrm{~cm}$ ). Novamente coloca-se que este critério de divisão é aleatório, mas que considera, sobretudo, a popularidade dos diâmetros encontrados. Neste caso, a média numérica seria de $37 \mathrm{~cm}$, porém este diâmetro é pouco freqüente no conjunto estudado (ver Anexo 6: Planilha 1). 


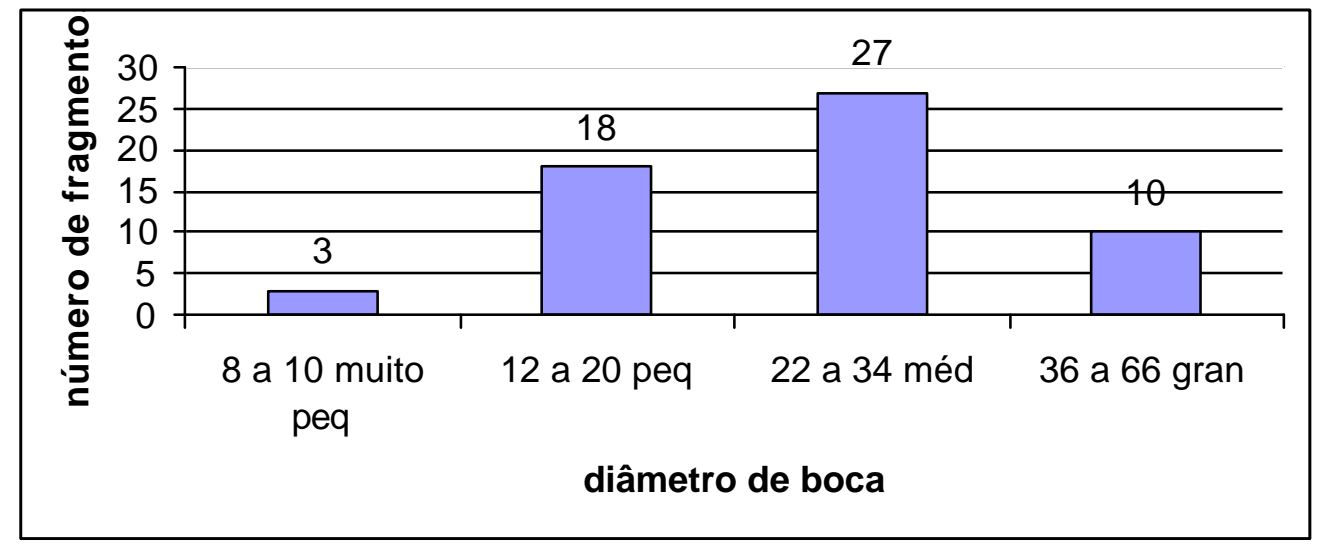

Gráfico 2 - Bordas de tigelas considerando diâmetro de boca e número de fragmentos.

Considerou-se a funcionalidade e o diâmetro de boca das vasilhas para uma melhor distribuição das dimensões. Assim, se modificados os critérios de classificação segundo somente as medidas do diâmetro, pode-se recair em outros erros que desconsideram o conjunto total dos fragmentos de borda estudados, bem como as coleções inteiras deste tipo de vasilhame.

Partindo do pressuposto que essa distribuição está correta, imagina-se que as tigelas muito pequenas e pequenas poderiam servir como pratos para servir ensopados individuais, enquanto os médios e grandes serviriam tanto para cozinhar como para consumir alimentos em refeições coletivas. Da mesma forma, é possível que o número de fragmentos, neste caso, não corresponda à totalidade das vasilhas em uso na ocasião de abandono do sítio. Por outro lado, a utilização constante deste tipo de vasilhas poderia exigir uma reposição constante que, durante a ocupação do sítio, não estariam sendo usadas concomitantemente. De qualquer forma, o predomínio de tigelas de tamanho médio sugere a ocupação por um grupo não muito grande, conforme o número de fogueiras e as concentrações dos diversos testemunhos, como será apresentado adiante. Uma hipótese de trabalho seria um número em torno de, talvez, três famílias nucleares, ou aproximadamente dezoito pessoas ou um pouco mais.

\subsubsection{Talhas}

As talhas são as vasilhas utilizadas para conter líquidos, geralmente pintadas e de grandes dimensões. Embora seu uso secundário seja como urna funerária, inicialmente deveria ser feita para conter água ou fermentar as bebidas alcoólicas. Estas jarras têm contorno complexo, segmentado, com vários pontos de ângulo, sendo $\mathrm{o}$ mais baixo deles correspondente à cintura e, geralmente, ao diâmetro máximo da vasilha. Normalmente, a cintura é situada acima da metade da altura da vasilha. Os pontos de ângulo formam carenas 
ou "ombros", que podem ser repetidos desde a cintura até a boca. O perfil da boca geralmente é voltado para dentro, cambado, introvertido. Raramente aparecem perfis de borda voltados para fora, exceto em talhas com forma de panelas, que se diferenciam pela pintura externa.

As talhas geralmente são pintadas externamente, e seus ombros podem conter diversas pinturas diferentes, de acordo com os pontos de ângulo. Em geral, os ombros são visíveis e divididos por pontos em ângulo acentuado que "marcam" o limite de cada faixa de pintura. Na maioria dos casos, uma linha vermelha é pintada sobre o ângulo, sendo que, em outros, a pintura vermelha pode ocupar toda a faixa (Anexo 3: Foto 20).

Embora não haja nenhum trabalho realizado a respeito, acredita-se que o estudo das pinturas e respectivas áreas de aplicação possam esclarecer alguns pontos, como:

- locais preferenciais de certos motivos;

- repetição de motivos em posições diferentes (lábio, primeiro, segundo ou terceiro ombro ou carena);

- exclusividade de motivos considerando espacialidade (motivos que se repetem nas vasilhas de determinada região ou bacia de rio).

Inicialmente, lança-se a hipótese de que os desenhos que compõem os motivos utilizados não aparecem em todos os locais, e aqueles que se repetem não apresentam a mesma frequiência (ver motivos em SCHMITZ, 1958, 1985 a 1991, SCHMITZ et al., 1990, p. 71-78). Uma pesquisa futura deverá sistematizar estes elementos (forma das vasilhas pintadas, motivos internos e externos, áreas de decoração) para resgatar possíveis diferenças culturais ou étnicas entre os Guaranis anteriores ao contato com o europeu (Anexo 3: Fotos 21 e 22).

No caso do sítio em estudo, as bordas de talhas estão em número reduzido, com as seguintes dimensões: uma borda com $24 \mathrm{~cm}$ de diâmetro, uma borda com $38 \mathrm{~cm}$ de diâmetro, uma borda com $48 \mathrm{~cm}$ de diâmetro e uma com diâmetro de boca impossível de reconstituição (ver Anexo 3: Foto 20 e Anexo 4: Gráfico 38).

\subsubsection{Tigelas de beber}

As tigelas de beber são os recipientes que, morfologicamente, se assemelham às tigelas de cozinhar. Segundo Brochado, Monticelli e Neumann (1990) são:

1. tigelas conoidais de contorno simples, abertas ou levemente restringidas. 2.Tigelas independentes, restringidas, de contorno infletido. 3. Tigelas abertas e levemente restringidas, de contorno composto ou complexo, com um ponto de ângulo marcando a junção da base conoidal com a borda convexa, reta ou côncava. 4. Tigelas independentes, levemente 
restringidas, de contorno complexo, com dois pontos de ângulo, o mais alto deles reentrante, na base de uma borda mais ou menos elaborada. (...) As formas mais simples são usualmente lisas, corrugadas ou unguladas; menos freqüentemente pintadas internamente; as formas mais complexas são usualmente pintadas externamente.

No sítio em questão, as formas mais freqüentes são as formas 1,3 e 4, das quais se realizam algumas observações. Como se trata de um conjunto pequeno de bordas (81 bordas) diferentes entre si, pode-se inferir algumas constantes neste conjunto (Anexo 3: Fotos 27, 28, 29 e 30$)$.

As tigelas de contorno complexo, com ponto de ângulo formando carena, possuem pintura externa. As bordas são verticais ou levemente infletidas, tendo os lábios verticais ou extrovertidos. A base raramente é esférica, sendo, em geral, conoidal, aplanada, pouco profunda. Como o ponto de ângulo é geralmente acentuado, a vasilha torna-se restringida (Anexo 3: Fotos 23, 24 e 25).

As tigelas de contorno simples, ao contrário, têm pintura interna, geralmente vermelha, mas com alguns exemplares de pintura vermelha sobre o branco. A base é em forma de meia esfera, e a vasilha é aberta e funda (Anexo 3: Foto 26 e 30). Embora se acredita que analogia etnográfica utilizada por Brochado, Monticelli e Neumann (1990) e Brochado e Monticelli (1994) seja de grande utilidade, a reconstrução das vasilhas a partir das bordas, no caso das tigelas de beber, fica bastante limitada por este fator, até agora não colocado por aqueles autores. Mesmo que sejam classificados na mesma categoria funcional (tigela de beber), os contornos das tigelas simples e complexas são diferentes no tocante as reconstruções, ${ }^{26} \mathrm{de}$ forma que se entende que as reconstruções gráficas só poderiam ser realizadas mediante a comparação com vasilhas inteiras da mesma região.

Brochado, Monticelli e Neumann (1990) apresentam as medidas médias paras as tigelas de beber entre 12 e $34 \mathrm{~cm}$. Neste caso, as vasilhas variam de 10 a $46 \mathrm{~cm}$. Desta forma, e considerando que estas vasilhas são destinadas ao consumo de alimentos, acredita-se que o conjunto pode ser dividido em vasilhas pequenas $(10$ a $16 \mathrm{~cm})$, médias $(18$ a $26 \mathrm{~cm})$, grandes $(28$ a $34 \mathrm{~cm}$ ) e muito grandes (acima de $36 \mathrm{~cm}$ ).

\footnotetext{
${ }^{26}$ Como exemplo, cita-se o trabalho de Carle (2002, p.145 et seq.), no qual a reconstrução das tigelas de beber (com pontos de ângulo) assume formas que não existem no universo das vasilhas inteiras.
} 


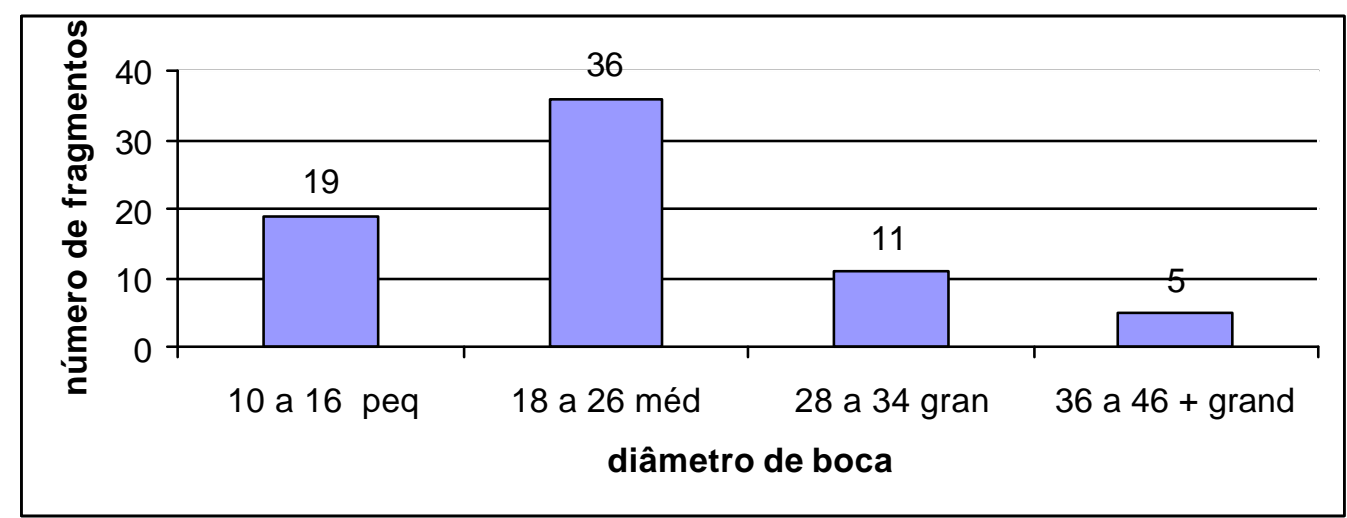

Gráfico 3 - Bordas de tigelas de beber, considerando diâmetro de boca e número de fragmentos.

Considerando que o uso destas tigelas está associado ao consumo de alimentos (uma vez que é consensual que as vasilhas pintadas não vão ao fogo), supõe-se que, sendo a maioria das tigelas de beber de tamanho médio, seguido pelas pequenas, a ocupação desta habitação se deu por um número limitado de pessoas. Ao mesmo tempo, o número de fragmentos que corresponderiam a tigelas grandes e muito grandes é inferior aos fragmentos de vasilhas pequenas, o que confirmaria a hipótese de que se está tratando de um grupo com poucas pessoas, ou não haveria atividade social que justificasse o beber coletivamente.

Por outro lado, as dimensões muito pequenas e muito grandes de cada categoria funcional colocam em cheque sua verdadeira utilização. Geralmente classificadas como miniaturas, acredita-se que seja possível realizar uma revisão das classes funcionais de acordo com os conjuntos existentes em cada sítio, até que se possam redefinir parâmetros de inferência para estes usos. Assim, acredita-se que uma vasilha de $8 \mathrm{~cm}$ de diâmetro muito dificilmente fora utilizada para consumo de bebidas, a menos que se tenham dados mais concretos sobre a confecção deste tipo de artefatos por crianças ou com fins específicos, que as análises atuais não permitem inferir. Da mesma forma, as tigelas com $46 \mathrm{~cm}$ de diâmetro podem (e talvez devam) ser repensadas como local de fermentação e guarda de bebidas, tanto como as talhas, em face de suas dimensões. Estas questões só poderão ser mais bem esclarecidas à medida que novas habitações forem escavadas em grandes superfícies, ao mesmo tempo em que apresentem seus testemunhos suficientemente conservados para a inferência do uso dos espaços.

\subsubsection{Pratos}

Os pratos de comer, segundo Brochado, Monticelli e Neumann (1990), "têm base arredondada, borda direta ou côncava, inclinada para fora". Pode-se dizer ainda que são rasos, 
pois, ao contrário, seriam classificados como tigelas. Os pratos apresentam tanto o tratamento de superfície corrugado e corrugado-ungulado como as decorações lisa e ungulada (Anexo 3: Fotos 31 e 32). O diâmetro, segundo os autores supracitados seria entre 12 e $34 \mathrm{~cm}$. Neste estudo de caso, encontraram-se vasilhas desde 12 até $40 \mathrm{~cm}$ de boca. Da mesma forma que tigelas de beber, poder-se-ia classificar os pratos em pequenos (12 a $16 \mathrm{~cm})$, médios (18 a 24 $\mathrm{cm})$ e grandes $(26 \mathrm{a} 40 \mathrm{~cm})$.

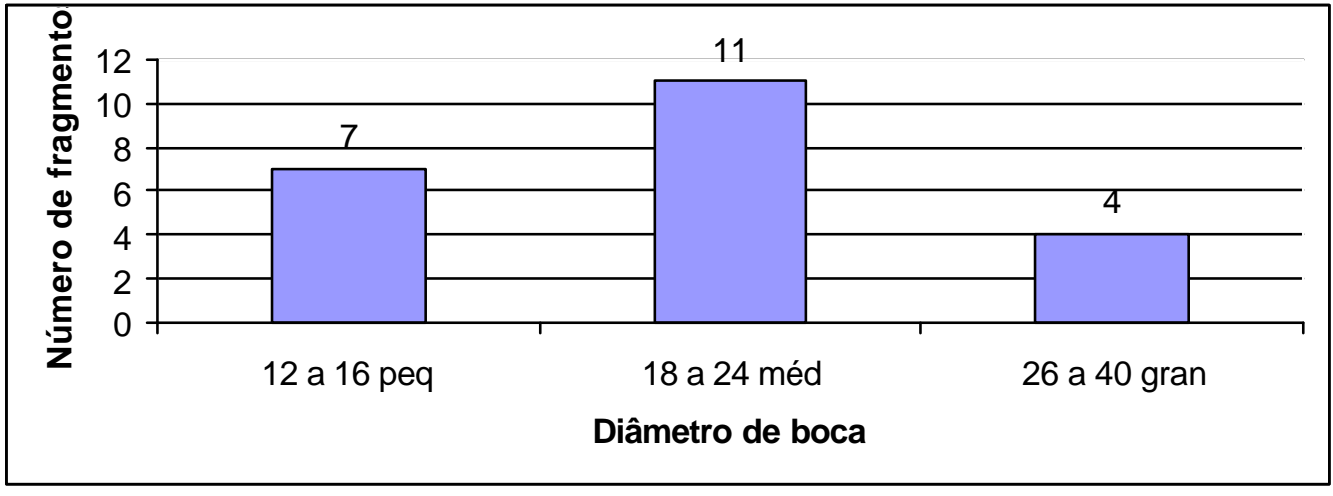

Gráfico 4 - Bordas de pratos de comer, considerando diâmetro de boca e número de fragmentos.

A análise da quantidade de fragmentos de borda de pratos sugere que as refeições ocorriam em maior quantidade em pratos de porte médio, uma vez que a soma entre as vasilhas pequenas e grandes é igual ao número de vasilhas médias. Também parece que, segundo este critério de separação, as refeições deveriam ser coletivas, uma vez que os pratos médios e grandes serviriam a refeições comunais. Em contrapartida, parece que as atividades sociais eram raras ou pouco freqüentes, pois tanto os pratos como as tigelas de beber de tamanho grande são escassas. Tampouco as panelas e as tigelas de cozinhar apresentam uma quantidade significativa de vasilhas de porte grande.

Outra questão peculiar acontece com a classificação de pratos. A diferenciação entre pratos e tigelas ocorre principalmente em função da profundidade, uma vez que os diâmetros grandes (nas tigelas, acima de $36 \mathrm{~cm} \mathrm{e}$, nos pratos, acima de $26 \mathrm{~cm}$ ) poderiam confundir as respectivas classificações. Em seu trabalho, ainda inédito, ${ }^{27}$ Jacobus trata a questão da seguinte forma:

Propomos que estas relações sejam definidas dividindo a vasilha em três partes, no sentido horizontal para a profundidade, e no sentido vertical para a abertura. Assim teremos vasilhas fundas quando suas alturas forem

\footnotetext{
${ }^{27}$ Ver nota 22.
} 
maiores ou iguais a dois terços de seus diâmetros máximos, cujos índices serão maiores ou iguais a 0,7 (de 0,66). De outro modo teremos vasilhas rasas quando suas alturas forem menores ou iguais do que um terço de seus diâmetros máximos, cujos índices serão menores ou iguais a 0,3 (de 0,33 ). Aquelas que apresentarem índice maior do que 0,3 e menor do que 0,7 serão de profundidade mediana. (...) Entre as ñaetá (tigelas, nota do autor) e as ñaembé (pratos, nda) a distinção se fez pela profundidade, predominando as medianas para as primeiras e as rasas para as segundas.

Sendo assim, a classificação em pratos ou tigelas seguiu este critério, ou seja, da inclinação do perfil da borda em relação ao sentido horizontal do diâmetro de boca. Mesmo assim, uma vez que se está tratando de fragmentos de borda, registra-se a dificuldade de classificação e o esclarecimento nos critérios aqui utilizados.

\subsubsection{Testemunhos fugazes}

Os testemunhos fugazes no sítio RS-JC-57 são representados pelas manchas decorrentes da alteração do solo em contato com o fogo, causando o escurecimento do sedimento. Ao longo da escavação, foram detectadas diferentes manchas no solo, decorrentes da decomposição da matéria orgânica, no caso da área de descarte, ou das atividades onde o fogo estava presente na área de habitação. O resultado disso foi o registro de lentes de solo antropogênico ricas em evidências, no caso da área de descarte, e das áreas de fogueira, fogos e fogões na habitação.

Ainda foram registrados e recolhidos pequenos pedaços de argila queimada, sem forma definida, mas endurecidas pela ação do fogo e amostras de terra calcinada. No item quatro, serão relacionados espacialmente esses testemunhos que apontam com maior precisão as áreas de fogueiras e fogões.

O objetivo deste item é tratar o sedimento localizado no sítio arqueológico na área de habitação e na área de descarte como artefatos, no sentido que sofreram ações humanas, propositais ou não. Renfrew e Bahn (1993, p.43-44) consideram as alterações promovidas pelo homem em seu meio como parte da cultura material das sociedades pretéritas. Assim, as análises de sedimento têm por objetivo demonstrar que a ação humana é perceptível e identificável através dos componentes químicos que restaram e podem auxiliar na interpretação das ações que o causaram.

Foram realizadas duas análises diferentes de solo:

- elementos disponíveis para plantas, realizadas pelo Laboratório Central de Análises de Solo (Departamento de Solos, Centro de Ciências Rurais - UFSM), sob responsabilidade do Pesquisador Luiz Finamor; 
- digestão total, realizadas pela Embrapa (Rio de Janeiro) sob responsabilidade do Dr. Vinicius Benites (DSc Solos e Nutrição de Plantas - Embrapa Solos) e a pesquisadora PhD. Beáta Madari (Sistemas de Produção - Embrapa Solos); também amostras de solo analisadas por digestão total foram realizadas pela Dra. Dirse Kern, através do Museu Paraense Emílio Goeldi;

As amostras analisadas são sedimentos da área de descarte que passaram ou não por uma retirada de macrovestígios de matéria orgânica, como sementes, ossos, folhas, raízes, fragmentos de cerâmica e lítico, visíveis a olho nu (amostra 1: sedimentos sem peneiramento e amostra 2: sedimentos com peneiramento). Também foram analisadas amostras de solo antropogênico da habitação e do mesmo nível estratigráfico da área que seria fora da habitação (amostra 3: solo da habitação sem peneiramento e amostra 4: solo adjacente). Essa abordagem permitiu a análise de solos contemporâneos ao sítio (no mesmo nível estratigráfico), porém sem alterações visíveis na composição do solo. Essa amostra foi retirada de um local que não apresentou artefatos durante a escavação do núcleo antropogênico.

\subsubsection{Análise dos elementos disponíveis para plantas}

As análises realizadas pelo Laboratório Central de Análises de Solo (UFSM) foram processadas somente nos três primeiros tipos anteriores, não sendo realizada análise do solo adjacente.

As amostras estão assim discriminadas na Tabela 1:

- amostra do sedimento da área de descarte com peneiramento (denominado: área de descarte sem ossos);

- amostra do sedimento da área de descarte sem peneiramento (denominado: área de descarte com ossos);

- amostra do solo antropogênico da área de habitação: Setor 1 (Coordenadas da escavação segundo os eixos X e Y, conforme Anexo 1, Desenhos 4 e 5, sendo as coordenadas $\mathrm{X}$ relativas ao eixo de $4 \mathrm{~m}$ e as coordenadas $\mathrm{Y}$ relativas ao eixo de 8 metros. Assim, $\mathrm{X}=0,5$ significa o local exato do recolhimento da amostra, coordenadas $\mathrm{X}=0,5$ metros e coordenadas $\mathrm{Y}=8,00$ metros).

Através dessa análise e considerando que os elementos são indicados quando disponíveis para absorção dos vegetais (cultivos), obteve-se os resultados apresentados na Tabela 1 (para resultado completo ver Anexo 5: Tabela 2). 
Tabela 1-Resumo das análises de solo realizadas pelo Laboratório Central de Análises de Solo

\begin{tabular}{l|c|c|c|c|c|c}
\hline N. Registro & Amostra & $\mathrm{P}$ & $\mathrm{K}$ & $\%$ M.O. & $\mathrm{Ca}$ & $\mathrm{Mg}$ \\
\hline 7947 & 1- área de descartesem ossos & 69.5 & 194 & 4.8 & 18.2 & 1.8 \\
\hline 7948 & 2- área de descarte com ossos & 69.5 & 92 & 5.7 & 22 & 1.6 \\
\hline 7949 & 3- setor 1 X=0,5m, Y=8 m & 23.2 & $>200$ & 3.9 & 13.5 & 1.9 \\
\hline
\end{tabular}

Em que: $\mathrm{P}=$ fósforo; $\mathrm{K}=$ potássio; \% M.O.= percentagem de matéria orgânica; $\mathrm{Ca}=$ cálcio e $\mathrm{Mg}=$ magnésio.

Em uma breve análise dos elementos disponíveis, observa-se que os índices de Cálcio (Ca), Fósforo (P) e Potássio (K), bem como a percentagem de Matéria Orgânica (\%M.O.) foram consideradas altas em relação aos solos da região do município de Ibarama e vale do rio Jacuí. Segundo o pesquisador Luiz Finamor, esses índices, especialmente de cálcio, revelam uma grande quantidade de matéria orgânica decomposta, principalmente por dois fatores:

1) na profundidade de recolhimento das amostras (talude do rio e 80 a $100 \mathrm{~cm}$ de profundidade na área de escavação) é praticamente impossível encontrar-se cálcio disponível, seja pela baixa lixiviação deste elemento ou pela desagregação natural. Segundo este mesmo pesquisador, estes elementos são encontrados em, no máximo, 5 a $10 \mathrm{~cm}$ de profundidade, em solos agricultáveis;

2) o índice de potássio é bastante elevado, provavelmente advindos de queima ou cinzas, que igualmente não são comuns de existirem na referida profundidade. Quando a análise foi realizada, o índice apresentado (>200) indicou uma quantidade superior a duzentos miligramas por litro, que não é registrado em virtude das análises de solo serem voltadas para uso agrícola.

Ainda segundo o pesquisador Luiz Finamor, esses índices estão acima da média para o vale do rio Jacuí, sendo resultado das seguintes possibilidades, concomitantes ou não:

- decomposição de cinzas, que elevaram os teores de potássio;

- decomposição de matéria orgânica animal, que possibilitou a fixação do cálcio em um local onde estes elementos não estão presentes em virtude da percolação, lixiviação e desagregação natural.

\subsubsection{Digestão total das amostras}

A digestão total é a quantificação total dos elementos presentes nas amostras, conforme a Embrapa (1997). As amostras foram classificadas da seguinte forma:

- amostra 1 = Área de descarte sem peneiramento;

- amostra 2 = Área de descarte com peneiramento; 
- amostra 3 = Área de escavação sem peneiramento;

- amostra 4 = Solo adjacente.

Após a digestão, foram determinados os teores de 14 elementos nos extratos, sendo apresentados na Tabela 2 os mais relevantes (para resultado completo, ver Anexo 5: Tabela $1)$.

Tabela 2 - Resumo dos elementos analisados em digestão total

\begin{tabular}{c|c|c|c|c}
$\begin{array}{c}\text { Elemento } \\
(\mathrm{g} / \mathrm{Kg})\end{array}$ & Amostra 1 & Amostra 2 & Amostra 3 & Amostra 4 \\
\hline $\mathrm{Ca}$ & 14.1 & 13.6 & 3.60 & 1.73 \\
\hline $\mathrm{Mg}$ & 2.35 & 2.35 & 2.15 & 1.70 \\
\hline $\mathrm{K}$ & 1.06 & 1.07 & 1.28 & 0.840 \\
\hline $\mathrm{Na}$ & 0.170 & 0.178 & 0.117 & 0.095 \\
\hline $\mathrm{Zn}$ & 0.104 & 0.119 & 0.118 & 0.079 \\
\hline
\end{tabular}

Em que $\mathrm{Ca}=$ cálcio; $\mathrm{Mg}=$ magnésio; $\mathrm{K}=$ potássio e $\mathrm{Na}=$ sódio (tabela completa no Anexo 5).

Nessas mesmas amostras foram determinadas, pelo analisador de elmentos (Perkin Elmer CHNS), os teores de carbono e nitrogênio totais (Tabela 3).

Tabela 3- Concentrações de C (carbono), N (nitrogênio) e relação entre C/N (carbono nitrogênio) das amostras

\begin{tabular}{l|l|l|l|l}
\hline \multicolumn{1}{c|}{ Elemento (\%) } & \multicolumn{1}{|c|}{ Amostra 1 } & \multicolumn{1}{c}{ Amostra 2 } & \multicolumn{1}{c}{ Amostra 3 } & Amostra 4 \\
\hline $\mathrm{C}$ & 4.04 & 4.22 & 2.70 & 0.77 \\
\hline $\mathrm{N}$ & 0.23 & 0.25 & 0.24 & 0.06 \\
\hline relação C/N & 17.6 & 16.9 & 11.3 & 12.8
\end{tabular}

Foram também analisados atributos da fertilidade do solo no Laboratório de rotina de análises de solos e plantas da Embrapa Solos (LASP), segundo metodologia adotada pela Embrapa (1997), apenas nas amostras 2 (área de descarte) e 3 (área de escavação (Anexo 5: Tabela 1).

Segundo comunicação pessoal de Beáta Madari, os itens que compõem a análise de solo (Anexo 5: Tabela 1) podem ser lidos da seguinte forma, segundo as necessidades deste trabalho:

- pH: em geral, alta para os solos no Brasil. A presença de $C a$ e outros cátions básicos (cátions com reação básica em água - $\mathrm{Ca}, \mathrm{Mg}, \mathrm{K}, \mathrm{Na}$ ) causam isto;

- Ca: muito alta no solo e na área de descarte também. Se a rocha em que o solo formou não tem carbonato de $\mathrm{Ca}\left(\mathrm{CaCO}_{3}\right)$, isto pode ser sugestivo à origem antropogênica, 
especialmente junto com os altos teores de $P$ (fósforo) [Observação: não há carbonatação no local do sítio ou do talude do rio, de forma que se exclui a possibilidade do cálcio ter origem na formação do solo];

- valor S: é a soma de $\mathrm{Ca}, \mathrm{Mg}, \mathrm{K}, \mathrm{Na}$. Aqui o $\mathrm{Ca}$ domina e não está acompanhado do $M g$ (alta relação $\mathrm{Ca} / \mathrm{Mg}$ ). Isto pode sugerir origem orgânica de $\mathrm{Ca}$;

- $A l_{3}+$ : as terras pretas também, geralmente, não têm $A l$ trocável. Isto pode ser explicado com o alto teor de $\mathrm{Ca}$ e $\mathrm{Mg}$, e alto $\mathrm{pH}$;

- valor T: soma de todos os cátions, inclusive $A l$ e $H$. Em geral mostra a capacidade do solo para armazenar e trocar cátions no solo (complexo sorptivo do solo). É importante em relação à fertilidade do solo. Só pelo valor de $\mathrm{T}$ ainda não se pode avaliar se esta capacidade do solo é boa ou não. Um alto T em geral é desejável para poder ter maior fertilidade do solo;

- valor V (saturação por bases): S/T*100. A porcentagem de cátions básicos (valor $\mathrm{S}$, nutrientes importantes para as plantas, especialmente $C a, M g, K$ ) em relação ao valor T (todos os cátions, $A l$ e $H$ não são desejáveis nos solos) no complexo sorptivo do solo. Alto valor $\mathrm{V}$ é muito desejável no solo. Mas nos solos geralmente ácidos, no Brasil, isto é baixo. Tanto neste solo (amostra 3) como no lixo este valor é muito alto comparado com solos brasileiros em geral;

- $P$ assimilável para as plantas: muito alto comparado com solos brasileiros. Geralmente é sugestivo de origem antropogênica. Junto com altos teores de $C a$ (que é o caso aqui) pode indicar origem animal da $\mathrm{Ca}$ e $P$ (ossos);

- $C$ orgânico: não é exageradamente alto, mas só isto não sugere origem antopogênica;

- $C$ total: em si também não é exageradamente alto. Comparado ao solo adjacente (amostra 4), o C total na área de escavação é razoavelmente alto. Junto com os outros resultados $(\mathrm{Ca}, \mathrm{P})$ pode ser indicador de ação antropogênica. $\mathrm{O}$ carbono resistente $(C$ total $-C$ orgânico), que pode ser parcialmente $C$ pirogênico, na amostra 3 é de $22 \%$ (do $C$ total). Este é um teor mais alto do que normalmente (acumulado como resultado de queimas naturais) é encontrado nos solos (14-15\% na Amazônia, por exemplo). Isto pode ser sugestivo de atividade antrópica. No lixo esta porcentagem é 14\%, ou seja, provavelmente não tem excesso de carvão [Observação: confere com a suposição de que o local era a área de descarte de matéria orgânica e artefatos não mais desejados, ou seja, sem presença de carvão, que poderia ter origem natural];

- $C / N$ : a razão $C / N$ no solo é normal (entre 10-13), típico de solos minerais (solos onde, em geral, não têm excesso de matéria orgânica, por exemplo, organossolos, onde este valor é diferente). No lixo é maior, o que significa matéria orgânica menos umificada, menos estável, 
mas isto só tem a ver com o fato de que o material é de lixo, ou seja, matéria orgânica acumulada de diferentes origens.

Sendo assim, as análises realizadas, segundo os geólogos Vinícius Benites e Beáta Madari, apresentam os seguintes elementos:

- a área de descarte é enriquecida em cálcio e os setores de magnésio não acompanham este enriquecimento, o que sugere que a origem deste elemento não é mineral;

- os maiores teores de carbono e a maior relação $C: N$ indica predominância de cinzas na matéria orgânica da área de descarte (resultados semelhantes são encontrados nas TPI [terra preta de índio] da Amazônia: alta relação $C a: M g$ e alta relação $C: N$ );

- tanto a área de descarte quanto a área de escavação apresentaram excelente fertilidade com níveis de nutrientes disponíveis (inclusive fósforo) bastante superiores aos encontrados em solos agricultáveis do Brasil;

- a existência de zinco nas amostras não é comum. É possível que o zinco tenha sido acumulado por resíduo de alimentos.

Com base nessas análises, é possível realizar as seguintes considerações: o enriquecimento dos elementos de cálcio e magnésio é, provavelmente, causado por acúmulo de resíduos animais e/ou vegetais, onde houve uma concentração seletiva de cálcio (elemento essencial na biomassa). Pelas análises do solo adjacente, os teores de cálcio e, principalmente, a relação entre cálcio e magnésio não condizem com os valores encontrados na área de descarte, praticamente impossibilitando a associação dos valores da área de descarte a situações naturalmente encontradas nos solos e rochas da região (deve-se salientar que não existe jazida de calcário próxima a escavação, que poderia ser uma outra fonte de cálcio).

Contudo, pela similaridade com os dados encontrados na terra preta de índio (alta relação cálcio/magnésio, alta matéria orgânica pirogênica) é muito provável que o local considerado como área de descarte seja realmente uma área de descarte de resíduos de alimentos associados a resíduos de fogueiras.

Outro elemento que aponta para a configuração de uma área de descarte é a relação carbono-nitrogênio. Quando a matéria orgânica passa pela decomposição microbiana (putrefação), as relações entre carbono/nitrogênio são em torno de 12 , que é a relação $C: N$ de materiais estabilizados biologicamente, correspondendo a relação $C: N$ encontrada na biomassa microbiana. Logo, matéria orgânica residual com alta relação $C: N$ deve ser mesmo formada por estruturas altamente recalcitrantes, com alta aromaticidade, tal como a matéria orgânica pirogênica derivada da transformação de carvões e resíduos de queima, além dos próprios fragmentos de carvão. 
Encontrou-se elevados teores de potássio em cinzas (cinzas de queima) e, provavelmente, parte deste potássio já foi lixiviado ao longo dos anos. O maior teor deste elemento na área de descarte e na área de escavação em relação ao solo adjacente indica uma concentração do elemento provavelmente pela deposição de cinzas por atividade antrópica em ambiente protegido da lixiviação.

Segundo Dirse Kern (comunicação pessoal), pode-se também sugerir um uso diferenciado dos espaços conforme a concentração dos elementos:

os altos teores de $\mathrm{Ca}, \mathrm{Mg}, \mathrm{P}, \mathrm{K}, \mathrm{Na}, \mathrm{Mn}$ e C, nos solos do sítio RS-JC-57, foram adicionados pelo homem préhistórico na forma de resíduos orgânicos principalmente de origem animal, pois, tanto ossos como sangue são altamente ricos principalmente em fósforo e cálcio. Os valores de $\mathrm{pH}$ são mais elevados na área do sítio por estarem intimamente relacionados com a matéria orgânica depositada. Os elevados valores dos elementos também corroboram com a hipótese de haver nesse sítio locais preferenciais de descarte de material (lixeira) e locais que podem ter sido deixados propositadamente mais limpo (escavação). Na 'escavação', onde os teores de Ca e P é menor que na 'lixeira', é comum encontrar teores mais elevados de sódio e potássio. Esse fato pode estar ligado à diferenciação do material orgânico descartado. Nesses locais pode ter havido predomínio de matérias como pêlos, cabelos, pele, escamas, entro outros dejetos, que são ricos nestes elementos. Enquanto nos locais de 'lixeira', além desses, vários outros resíduos orgânicos faziam parte do material descartado, como ossos, sangue, couro, fibras vegetais, etc.

Nos sítios de Terra Preta Antropogênica (TPA), os elevados índices dos elementos supracitados estão diretamente associados a ação humana (GLASER, 2002/03), além da presença de material orgânico com queima incompleta (black carbon) que, no caso da Amazônia, chega a ser setenta vezes maior que nas áreas adjacentes (GLASER et al, 2001). Ao mesmo tempo, a ocorrência de carvão nos solos de terra preta amazônicos estão associadas a locais de combustão, o que aumenta a matéria orgânica destes solos (GLASER et al, 2001).

Estas análises já foram realizadas para outros sítios arqueológicos Tupi-Guaranis, ${ }^{28}$ como pode ser observado em diversos trabalhos de Pallestrini (1969, 1968/1969, 1972/1973). Os resultados, com base em análises físicas e químicas do solo, demonstram grandes diferenças entre os teores de cálcio, magnésio, carbono e nitrogênio dentro e fora dos núcleos de solo antropogênico. Pallestrini (1969, 1968/1969, 1972/1973) afirma que os elevados índices destes elementos confirmam a ocupação pretérita, embora restrinja o caráter da ocupação apenas ao local de habitação. Conforme as análises realizadas em sedimentos da área de descarte, pode-se afirmar que a alteração na composição química do solo deve-se ao

\footnotetext{
${ }^{28}$ Há discordância se os sítios do Paranapanema paulista podem ser atribuídos a os antepassados dos Tupinambás ou dos Guaranis. Brochado atribuiu estes sítios aos Guaranis (1984, p. 410), mas mudou de idéia e filiou estes sítios aos antepassados dos Tupinambás (conforme NOELLI, 1993, p. 103, segundo comunicação pessoal), em virtude da forma e do tratamento de superfície da cerâmica.
} 
uso humano, independente da função de cada espaço. No entanto, a contribuição de Pallestrini é determinante, pois mostra a preocupação de resgate de maior número de testemunhos; neste caso, o solo como artefato manipulado por populações pretéritas. É ainda maior o mérito dessa autora, pois, passados mais de trinta anos da realização desses trabalhos, poucos pesquisadores seguiram a análise dos testemunhos fugazes.

Em outros sítios arqueológicos, como o sítio Belterra (Santarém, Estado do Pará), as análises de "terra preta" são igualmente comparáveis às descritas acima (ver, por exemplo, PABST,1991, e Anexo 5: Tabelas 2 e 3).

Desta maneira, embora pedólogos, geólogos e antropólogos não estejam em consenso a respeito da origem antropogênica da "terra preta", as análises levadas a cabo no sítio RS-JC57 permite inferir que as áreas denominadas de área de descarte e habitação são, de fato, de origem antropogênica.

Embora seja consensual que as "terras pretas" ou "manchas pretas" sejam consideradas remanescentes de habitações indígenas, é necessário ressaltar que as atividades humanas possam ser divididas em diversas categorias (como "área de descarte" e "habitação"), mas trata-se inequivocamente de evidências de atividade humana pretérita.

\subsubsection{Testemunhos discretos}

Consideram-se testemunhos discretos os resíduos de lascamento (lascas menores que um centímetro), representado por microlascas e estilhas, proveniente da preparação dos artefatos líticos e também os pequenos blocos de hematita (menores que um centímetro cúbico), utilizados como corante no processo de pintura das vasilhas cerâmicas. No item quatro será possível determinar que a distribuição dos resíduos de lascamento, associada à distribuição dos núcleos utilizados, permite a estimativa das áreas de lascamento no interior da habitação.

As microlascas e as estilhas estão inequivocamente associadas ao descorticamento causado pela ação do fogo sobre os núcleos de calcedônia. São centenas de exemplares que não serão consideradas aqui por que não resultam da ação humana e sim da ação de preparação dos núcleos. Salienta-se, ainda, que existe um pequeno número de microlascas advindas da preparação de artefatos, mas estas encontram-se dispersas nas áreas de fogos e fogueiras, já delimitadas por outros elementos, como será retomado no capítulo quatro. Como já dito, o objetivo deste trabalho não é a reconstituição da cadeia operatória, mas o significado 
social da distribuição dos artefatos, de forma que a análise dos testemunhos discretos será centrada nos pequenos blocos de hematita encontrados na escavação.

São dezoito pequenos blocos de hematita espalhados em todos os setores que, muito provavelmente, foram utilizados como corantes na confecção de vasilhas cerâmicas ou em outros usos nos quais está envolvida a pintura de cor vermelha. Esses blocos possuem dimensões diminutas (em torno de $1 \mathrm{~cm}^{3}$ ), que se decompõem com facilidade no contato manual.

\subsubsection{Testemunhos negativos}

Neste estudo, os testemunhos negativos estão representados pela ausência de artefatos nas camadas arqueológicas, negativos resultantes de materiais perecíveis, mudanças na coloração do solo ou decomposição de matéria orgânica, como vegetais ou ossos animais. Não se podem confundir estes testemunhos com as ações pós-deposicionais que atuaram no sítio após seu abandono. Exemplos destas perturbações são observados pela ação argiloturbadora (MILDER, 2000) que infiltrou sedimentos e materiais arqueológicos desde os níveis ocupados, carregando sedimentos e materiais para níveis abaixo do núcleo antropogênico que estava sendo escavado (Anexo 2: Foto 13).

No entanto, a distribuição dos artefatos, como será apresentado no capítulo quatro, demonstrará a existência de diversos espaços "vazios", que podem determinar diversas hipóteses sobre sua ocupação.

Também como testemunhos negativos podem ser citados os negativos de esteio, nos quais a decomposição do material orgânico foi sucedida de mudança na coloração do solo e desaparecimento do artefato original (Anexo 2: Foto 14). Os dois negativos de esteio localizados na escavação permitem inferir que se tratava de uma habitação de dimensões

médias (aproximadamente $120 \mathrm{~m}^{2}: 15 \times 8 \mathrm{~m}^{2}$ ), considerando os padrões dos sítios pesquisados no vale do rio Jacuí (ver capítulo 1, fase Guaratã).

É interessante observar a passagem descrita por Brochado (1969, p. 39) sobre os esteios registrados em sítios da fase Toropi (rio Jacuí): "No interior do conjunto observou-se vestígios de postes de $20 \mathrm{~cm}$ de diâmetro, alcançando até $40 \mathrm{~cm}$ de profundidade", semelhantes a este estudo de caso, embora os esteios escavados não ultrapassassem $15 \mathrm{~cm}$ de diâmetro, ao mesmo tempo em que a orientação espacial da casa assemelha-se ao citado na região (Fases Toropi e Guaratã). 
É importante resgatar aqui o que Noelli (1993, p. 89) descreve a respeito dos negativos de esteio:

Os testemunhos negativos representados aqui pelos esteios da casa, são chamados por Chmyz (e pelos que pesquisaram os sítios Guarani) pelo termo inexato de 'buracos de estaca'. Pesquisadores da arquitetura de sociedades indígenas brasileira definiram um glossário da habitação e 'estaca' foi considerado como 'pau aguçado que se crava no chão ou em qualquer lugar com diversas finalidades'. Esteio é uma 'peça de madeira fincada verticalmente na terra para sustentar frechais, terças e cumeeiras'.

Sendo assim, destaca-se a evidenciação de dois negativos de esteio, uma vez que se alinham com outro esteio localizado no setor $\mathrm{V}$, ao mesmo tempo em que não estão em número suficiente para formar uma estrutura menor (como um jirau, ver CARLE, 2002).

A disposição desses negativos bem como a distribuição espacial dos outros testemunhos ajudará a definir os espaços e seus usos na habitação, conforme será apresentado no capítulo quatro. 


\section{DATAÇÕES OBTIDAS PARA O SÍTIO}

A escavação do sítio RS-JC-57 possui talvez o maior conjunto de datas para a ocupação Guarani na região sul e, quiçá, da região platina. São dezoito datas de TL e LOE processadas pelo LACIFID e quatro pela FATEC-SP (Anexo 7) somente para este sítio, além de outras quatro para sítios próximos no mesmo vale do rio Jacuí. Além destas, existe uma data de radiocarbono (realizada pelo Beta Analytic - Anexo 7) e outras em processamento. Com este conjunto, agregados a realização de outras datas em perfeita consonância com outros sítios datados pelo mesmo método, pode-se questionar a antiguidade dos grupos Guaranis no vale do rio Jacuí.

Através do método da Termoluminescência (TL) e Luminescência Oticamente Estimulada (LOE), realizadas no Laboratório de Cristais Iônicos, Filmes e Datações (LACIFID) da USP, coordenado pelo professor doutor Shigueo Watanabe, foram processadas vinte e duas amostras de cerâmica e sedimento arqueológico. Em outras oportunidades, pôdese verificar a precisão do método através da datação de uma urna funerária Guarani pertencente ao período histórico (SOARES e MILDER, 2003), como será visto neste capítulo.

Porém, o processamento de outras datas por termoluminescência pela FATEC-SP, sob coordenação da professora doutora Sônia Tatumi, resultaram em datas diferentes daquelas processadas anteriormente. Ao mesmo tempo, a única data realizada por radiocarbono ampliou a problemática das datas de ocupação deste sítio. Sendo assim, optou-se por escolher um intervalo no qual seja possível incluir a ocupação Guarani no vale do médio rio Jacuí, e afirma-se que não se pretende validar um dos métodos ou laboratórios, evidenciando a dificuldade que representa uma série de datações sobre o mesmo sítio.

\subsection{Breve histórico das datações em sítios Guaranis}

Antes de apresentar as datações obtidas nos sítios RS-JC-56 e 57, é interessante apresentar as datações existentes, aceitas e não aceitas pelos pesquisadores, sobre a ocupação Guarani no Estado do Rio Grande do Sul. Para tanto, é necessário que se apresentem alguns pressupostos que orientaram a pesquisa em sítios arqueológicos no Rio Grande do Sul, no que concerne aos sítios Guaranis.

Os sítios arqueológicos dos horticultores estavam associados, no mais das vezes, à ocupação recente dos depósitos sedimentares e, por extensão, às camadas superficiais. 
Brochado (1984, p.252), em sua síntese, coloca a questão da seguinte forma: "With few exceptions, the thickness of the archaeological deposits does not exceed $30 \mathrm{~cm}$ to $40 \mathrm{~cm}$, and generally is only $15 \mathrm{~cm}$ to $20 \mathrm{~cm}$ '.

Assim, partindo da experiência empírica e dos modelos de rápida e recente expansão dos Guaranis, ${ }^{2}$ padronizoutse a ocupação dos horticultores Guaranis em até $50 \mathrm{~cm}$, embora houvesse diversas exceções que, no entanto, só confirmaram a prática arqueológica de realizar sondagens até esta profundidade; padronizando, assim, os trabalhos de campo.

No caso de sítios classificados como pertencentes à Tradição Tupiguarani, há exemplos de sítios localizados em profundidades maiores que o usual, como demonstra a Tabela 1, que traz uma relação com todos os pesquisadores participantes do PRONAPA, os sítios e a avaliação de Meggers para as datas apresentadas.

Tabela 1 Dactiloscrito pertencente à Biblioteca de José Proenza Brochado, depos itado no Centro de Estudos e Pesquisas Arqueológicas - CEPA - PUC

Guanabara- Ondemar Dias

\begin{tabular}{c|l|l|l|l|l|r|l}
\hline DATE & *MASCA & LAB.N & PHASE & TYPE & SITE & LOCATION & EVALUATION \\
\hline $800 \pm 100$ & $824 \pm 100$ & SI-434 & Guaratiba & Tupiguarani & GB-6, & & Acceptable \\
AD 1150 & AD 1185 & & & & $90-100 \mathrm{~cm}$ & & \\
\hline
\end{tabular}

Paraná - Chymz

\begin{tabular}{l|l|l|l|l|l|l|l}
\hline $470- \pm 100$ & $484 \pm 100$ & SI- 694 & Umuarama & Tupiguarani & $\begin{array}{l}\text { PR-FL-5 } \\
80-100 \mathrm{~cm}\end{array}$ & $\begin{array}{l}\text { Paraíso do recent } \\
\text { Norte }\end{array}$ & Too rece \\
AD 1466 & & & & \\
\hline
\end{tabular}

Com base na Tabela 1, percebe-se que o Programa utilizou-se de critérios como profundidade para reforçar uma falsa idéia de cronologia, ${ }^{3}$ ao mesmo tempo em que a afirmação de que os sítios eram superficiais serviu de argumento para dinamizar a pesquisa de campo.

O desconhecimento dos fatores geológicos de formação de sítio aliados à pressa de prospecção acarretou no desconhecimento do subsolo onde eram encontrados sítios superficiais, uma vez que sondagens pouco profundas eram realizadas a partir do modelo existente.

\footnotetext{
1 "Com poucas exceções, a espessura dos depósitos arqueológicos excede 30 ou $40 \mathrm{~cm}$, e geralmente é somente 15 ou $20 \mathrm{~cm}$ ".

${ }^{2}$ Para uma crítica exaustiva do modelo de Meggers e Evans, ver Noelli (1993, p. 41-75).

3 Ver Milder (2000). Sítios paleoindígenas de mais de 9.500 anos BP encontram-se na superfície, assim como diversos elementos podem perturbar, inverter ou danificar a estratigrafia e o pressuposto "mais abaixo, mais antigo".
} 
Desta forma, preservou-se o modelo de ocupação das terras baixas da Amazônia (MEGGERS, 1994), de maneira que muitas datas mais antigas foram contestadas sem motivo aparente:

Not all the essays have been accepted by the investigators who have collected and submitted the samples. One suspects that most of the rejections result from the failure of the data to conform to the rigid preconceptions of the investigators. The pretext for rejection varies from investigator to investigator, and in most instances these pretext appear capricious (BROCHADO, 1984, p. 360). ${ }^{4}$

Acredita-se que um número significativo de datações nunca foi publicado ou discutido, o que demonstra que, mesmo que a antiguidade da ocupação Guarani seja ampliada e revista, persiste a ausência incômoda de uma síntese que reveja não somente a cronologia dos assentamentos, mas suas repercussões no desenvolvimento da agricultura e das sociedades complexas. Mesmo os resultados obtidos pelo próprio Brochado são tomados com reticência, uma vez que não há um continuum de ocupação no vale do rio Jacuí:

There is a C14 date of 1985 60 B.C. (SI-707) for one site of Irapuã Phase (2), not represented in the chart, that understandably has not been accepted, not only because it is too early but because there is no continuity between it and the next earliest dates. The two earliest $C_{14}$ dates shown in the chart, SI-418 from Cambará Phase site (12), and SI-1011 from one Tamboara Phase site (17), have not been accepted by some investigators, the first because of the gap between it and the next $C_{14}$ date for the same site, and the second because the pottery it dates allegedly shows characteristics that would place it later than that of other early sites in the same area on the Upper Paranapanema. However if the next oldest C14 date, SI-2205 (1), is to be accepted - wich is the case - the dates from Cambará Phase sites should be accepted also; bein on the Upper Paranapanema, they are nearer the more probable route of the spread of the Guarani up the Parana than the site from wich the Si-2205 date was obtained, wich is part of the Guaratã Phase of the Upper Jacui (1) (BROCHADO, 1984, p.361-362).5

\footnotetext{
4 "Nem todos artigos têm sido aceitos pelos investigadores que têm coletado e submetido amostras. Suspeitase que a maior parte da rejeição resulta da falha dos dados para sujeitar-se aos rígidos preconceitos dos investigadores. O pretexto para rejeição varia de investigador para investigador e, em muitos casos, estes pretextos parecem caprichos."

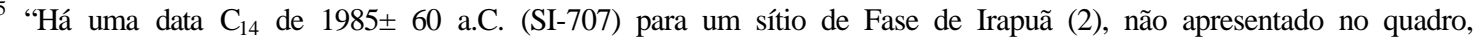
que compreensivelmente não foi aceito não somente porque é antiga, mas porque não há nenhuma continuidade entre ela e as próximas datas mais antigas. As duas datas mais antigas $\mathrm{C}_{14}$ mostradas no quadro, SI-418 do sítio da fase Cambará (12), e SI-1011 da Fase Tamboara (17), não foram aceitas por alguns investigadores, a primeira por causa do buraco entre ela e a próxima data $\mathrm{C}_{14}$ para o mesmo local, e a segunda porque a cerâmica que data supostamente mostra características que colocariam isto depois que a de outros locais antigos na mesma área no Paranapanema Superior. Porém se a próxima data C14 mais antiga, SI-2205 (1), que é o caso - as outras datas da Fase Cambará também deveriam ser aceitas; Sendo que no Paranapanema Superior elas estão mais próximas a rota mais provável da expansão do Guarani para cima o Paraná que o local que a data Si-2205 foi obtida, que é parte da Fase Guaratã do Jacuí Superior (1)".
} 
Ao mesmo tempo, Brochado (1984, p. 362) não coloca em sua tese uma série de datas que não possuem seqüência cronológica, seja por que não possuem seguimento com outros sítios, seja por que a aceitação de datas anteriores a $500 \mathrm{AD}$ seria fator complicante para os modelos de dispersão existentes:

There is no reason to believe that the $G_{4}$ dates (A.D. 1-200) of the earliest known manifestations of the Guarani pottery are not correct (SI-418* and SI$\left.2205^{* *}\right)$, especially in the light of the fact that the date of the next oldest site - also of the Guaratã Phase - is only slightly later (SI- 2203***). The date of the latter site, as have the others of the Upper Jacuí, come from my own research in colaboration with P.I. Schmitz (Schmitz, 1980), and have been accepted by everyone. $\left[*-\mathrm{AD} 80, * *_{-} 150, * * *-475 \text {, nota do autor }\right]^{6}$

There is a continuity of $C_{4}$ dates from the first century A.D. to the beginning of the nineteenth century. All these data indicate that the Guarani presence in Eastern South America has a time depth of the less than 1800 years.

Ainda nesta linha, Brochado encontrou grande dificuldade de, na época, mostrar a veracidade das datas em redor do ano zero da Era Cristã, tanto assim que algumas datas realizadas posteriormente ainda não foram consideradas verídicas, como aponta a bibliografia:

Therefore, the absence of earlier dates along the Paraná, commented upon in the text, does not exist anymore and I was right in estimating the beginning of the Guarani colonization of Southern Brazil ca. A.D. 1 or somewhat earlier. Nevertheless, Chmyz does not accept any of the 5 dates prior to A.D. 800 (BROCHADO, 1984, p.389, endnote to Chapter 12). ${ }^{8}$

Ainda hoje há resistência por parte de certos arqueólogos em aceitar datas próximas ao início da Era Cristã; Chmyz (1984, p. 103), por exemplo, considera a data de $60 \pm 75$ a.C. - SI5028 muito antiga. Desta forma, não é estranho que diversos dados nunca tenham sido colocados em pauta e tampouco publicados. Mais interessante ainda é observar que se as datas estivessem dentro do modelo, estariam corretas, enquanto aquelas que fugissem daquele, rapidamente seriam colocadas de lado em nome dos mais diversos fatores, como:

- a coleta imperfeita dos carvões para a datação;

- a contaminação das amostras;

\footnotetext{
6 "Não há nenhuma razão para acreditar que as datas $C_{14}$ (D.C. 1200) das manifestações conhecidas mais antigas da cerâmica de Guarani não estejam corretas (SI -418* e SI-2205**), especialmente a luz do fato que a data do próximo local mais antigo - também da Fase de Guaratã - chega só ligeiramente mais cedo (SI - $2203 * * *$ ). A data do local posterior, como os outros do Jacuí Superior, entre aqueles de minha própria pesquisa em colaboração com P.I. Schmitz (Schmitz, 1980), foi aceito por todo mundo.”

7 "Há uma continuidade de datas $\mathrm{C}_{14}$ do primeiro século D.C. para o começo do décimo nono século. Todos estes dados indicam que a presença de Guarani na América do Sul Oriental tem uma profundidade de tempo de, pelo menos, 1800 anos."

8 "Então, a ausência de datas mais antigas ao longo do Paraná, comentada acima no texto, não existe mais e eu tive razão calculando o começo da colonização de Guarani no Brasil Meridional cerca do ano 1 DC ou um pouco mais cedo. Não obstante, Chmyz não aceita nenhum das 5 datas antes do ano 800 DC." (Nota de final do Capítulo 12).
} 
- a quantidade "pequena" das amostras;

- a ausência de sequiência cronológica em outros sítios próximos.

Sendo assim, é natural acreditar que diversas datas ou não foram suficientemente estudadas ou caíram no esquecimento, quando se trata de apresentar a antiguidade da ocupação Guarani. Este é o caso, por exemplo, de algumas publicações de divulgação científica, na qual a data aceita permanece em torno do século V desta Era (AGUILAR, 2000). $\mathrm{Na}$ Tabela 2, algumas datas que não foram divulgadas ou pelo não reconhecimento dos autores como válidas, ou pela ausência de confiabilidade da técnica de radiocarbono na época. Na Tabela 3, o mesmo dactiloscrito citado na Tabela 1. Trata-se de uma relação com todos os pesquisadores participantes do PRONAPA, os sítios e a avaliação de Meggers para as datas apresentadas.

Tabela 2 - Datações não-calibradas que não foram aceitas pelo PRONAPA

\begin{tabular}{c|c|c|c}
\hline Sítio & Data & Tipo & Bibliografia \\
\hline Fase Cambará & A.D. $80 \pm 100$ & (SI-418) & Brochado, 1984, p.410 \\
\hline Itapeva: Fonseca & 1985 B.C. \pm 60 & (SI-707) & Brochado, 1984, p.412 \\
\hline RO-CO-04 & $2.465 \pm 65$ ou 515 a.C. & (SI-4784) & Miller, 1983 \\
\hline
\end{tabular}

Tabela 3- Dactiloscrito depositado no Centro de Estudos e Pesquisas Arqueológicas - CEPA PUCRS

São Paulo - Chmyz

\begin{tabular}{ll|l|l|l|l|ll}
\hline DATE & $*$ MASCA & LAB.N & PHASE & TYPE & SITE & LOCATION & EVALUATION \\
\hline $1870 \pm 100$ & $1926 \pm 100$ & SI-418 & Cambará & Tupiguarani & SP-BA-7 & Município & Too old \\
$20 \mathrm{BC}-10 \mathrm{BC}-$ & & & & $\begin{array}{l}\text { Corte A, } \\
15-30 \mathrm{~cm}\end{array}$ & Itaporanga & \\
$180 \mathrm{AD} \quad 210 \mathrm{AD}$ & & & & & \\
\hline
\end{tabular}

Paraná - Chmyz

\begin{tabular}{|c|c|c|c|c|c|c|c|}
\hline DATE & *MASCA & LAB. $N^{\circ}$ & PHASE & TYPE & SITE & LOCATION & EVALUATION \\
\hline $\begin{array}{l}7170 \pm 150 \\
5220 \mathrm{BC}\end{array}$ & $\begin{array}{l}7385 \pm 105 \\
5435 \mathrm{BC}\end{array}$ & SI-2196 & & Tupiguarani & $\begin{array}{l}\text { PR-LO-1 } \\
120-140 \mathrm{~cm}\end{array}$ & $\begin{array}{l}\text { Município } \\
\text {.Londrina }\end{array}$ & Too old \\
\hline $\begin{array}{l}1490 \pm 45 \\
\text { AD } 460\end{array}$ & $\begin{array}{l}1535 \pm 45 \\
\text { AD } 415\end{array}$ & $\begin{array}{l}\text { SI- } 1011 \\
\end{array}$ & Tamboara & Tupiguarani & $\begin{array}{l}\text { PR-FL-21 } \\
0-20 \mathrm{~cm}\end{array}$ & $\begin{array}{l}\text { Dr. Camargo } \\
\text { Corte B }\end{array}$ & Too old \\
\hline
\end{tabular}

Rio Grande do Sul - Miller

\begin{tabular}{l|l|l|l|l|l|l|l}
\hline DATE & *MASCA & LAB.N & PHASE & TYPE & SITE & LOCATION & EVALUATION \\
\hline $3935 \pm 60$ & $4053 \pm 60$ & SI-707 & Irapuã & Tupiguarani & RS- VZ-45 & $\begin{array}{l}\text { Tenente } \\
\text { Portela }\end{array}$ & Too old \\
1985 BC & 2103 BC & & & & & & \\
\hline
\end{tabular}


Rio Grande do Sul - Brochado

\begin{tabular}{ll|l|l|l|l|l|l}
\hline DATE & $*$ MASCA & LAB.N $^{\circ}$ & PHASE & TYPE & SITE & LOCATION & EVALUATION \\
\hline $1800 \pm 100$ & $1854 \pm 100$ & SI-2205 & Guaratã & Tupiguarani & RS-MJ-88 & Agudo & Too old \\
AD 150 & AD 160 & & & & & & \\
\hline
\end{tabular}

Importante ressaltar que, se por um lado Brochado (1984) aceita a data da fase Tamboara (460 AD) e sua própria da fase Guaratã (150 AD), é taxativo ao afirmar que aceita estas datas por tratar-se de um continuum de dados baseados no radiocarbono, descartando, inicialmente, aquelas que não têm continuidade cronológica no mesmo local ou vizinhanças. Conforme a Tabela 3, Betty Meggers (s.d.) avalia ambas como muito antigas, provavelmente em razão de que as aceitar obrigaria a revisão do modelo de dispersão cerâmica das terras baixas da Amazônia.

Estas questões devem ser levantadas à luz do sítio Wilmoth Ropke, que, segundo os arqueólogos que o localizaram e identificaram, ${ }^{9}$ apresentava uma mancha a $70 \mathrm{~cm}$ de profundidade, na barranca do rio Jacuí. Na escavação realizada, evidenciou-se uma ocupação definida abaixo de $80 \mathrm{~cm}$, não perturbada por ação de arado mecânico atual.

Consideram-se algumas passagens de interesse quanto as amostragens realizadas no vale do Rio Jacuí, datadas pelo método de $\mathrm{C}_{14}$ :

Em dois lugares da barranca (do sítio RS-MJ-71), distantes um do outro mais ou menos $5 \mathrm{~m}$, retiraram-se amostras de carvão, na mesma profundidade média. Uma delas, retirada a $55 \mathrm{~cm}$ de profundidade, deu $265 \pm 90$ AP (SI-2199) (SCHMITZ, ROGGE e ARNT, 2000, p. 36).

Observa-se também que este resultado, que não foi questionado, refere-se a uma barranca de rio, local onde uma série de perturbações - como pedoturbação, argiloturbação, bioturbação - podem ocorrer, mas não invalidaram a divulgação e aceitação das datas. Além das perturbações, a exposição à luz solar e intempéries, a contaminação por vegetais, animais e a distância entre os carvões simplesmente não foram considerados fatores dignos de discussão.

Na mesma publicação, referindo-se ao sítio RS-MJ-88, os autores colocam: "O carvão coletado proporcionou uma data de $1.800 \pm 100$ (S.I.-2205), considerada antiga demais" (SCHMITZ, ROGGE e ARNT, 2000, p.44). Por outro lado, sítios com datas aproximadas não foram contestados, como o sítio RS-MJ-101 (1.255 \pm 100, S.I.-2201, SCHMITZ, ROGGE e

\footnotetext{
9 Salvamento Arqueológico no Médio Jacuí, RS, Barragem Dona Francisca, 1981. São Leopoldo, IAP, 18 páginas. Relatório para a Companhia Estadual de Energia Elétrica por Ribeiro, Schmitz e Ferrari, relatório para CEEE, 1989; Schmitz, Rogge e Arnt, 2000; Ribeiro, 1996.
} 
ARNT, 2000, p.51) ou o sítio RS-MJ-60, com duas datas (1150 \pm 70, S.I.-2204 e $1475 \pm 80$, S.I.-2203, SCHMITZ, ROGGE e ARNT, 2000, p.30).

Sendo assim, acredita-se que a discussão sobre a antiguidade da ocupação Guarani no Estado do Rio Grande do Sul trata-se mais de uma questão de paradigma a ser discutido do que propriamente a validade dos métodos de datação. Isto pode ser observado em relação à ocupação do vale do rio Jacuí, uma vez que, participantes das pesquisas na área questionam a metodologia empregada. Brochado (comunicação pessoal em 21-01-2001) informa que as coletas realizadas nestes trabalhos não seguiam normas técnicas, não havendo, muitas vezes, controle sobre a retirada de amostras. Pode-se somar a ausência parcial de controle na amostragem, o descarte sumário das datas antigas relativas aos sítios Guaranis nos estados do sul do Brasil.

Nota-se, ainda, que mesmo o modelo proposto por Brochado (1984, p. 365) não negava o recuo das datas, faltando apenas dados concretos que permitissem a inclusão no modelo: "Given the earliest $G_{4}$ dates from the tributaires of the Paraná and Uruguay, the proto-Guarani must have started moving up the Madeira, out of Central Amazonia, by at least 200 B.C., or perhaps even earlier". ${ }^{10}$

Por outro lado, se o Carbono radioativo foi a base da cronologia utilizada em Arqueologia Guarani, hoje se sabe das diversas limitações que esta técnica apresenta fora de um contexto mais amplo. No caso das datas publicadas por Brochado (1984) e por Noelli (1999-2000), a maior parte não são calibradas, induzindo a um erro na passagem entre a data apresentada e o ano calêndrico. A passagem de Araújo (2001, apêndice 1) é longa, mas esclarecedora sob o ponto de vista que, em muitos casos, as datas são publicadas sem a devida calibragem, o que pode levar a um erro na interpretação dos resultados:

Toda data obtida pelo método do $\mathrm{C}_{14}$ necessita ser calibrada. A idade obtida quando se data alguma amostra que contenha carbono não equivale imediatamente a uma data do nosso calendário. Todos sabemos que o ano 'zero' nas datas radiocarbônicas é 1950, porém, a transformação de uma data radiocarbônica em uma data calêndrica não é feita pela simples operação aritmética da subtração de 1950 pela idade dada pelo $\mathrm{C}_{4}$. Não existe uma relação direta entre as duas datas, e isto foi sendo percebido quando se começou a comparar as datas obtidas pelo método radiocarbono a objetos cujas idades eram bem estabelecidas por outros métodos. (...)Até 1977, a meia-vida do carbono (Libby half-life) era considerada como sendo 5730 anos. Posteriormente percebeu-se que o valor mais próximo da realidade é 5568 anos. Se a idade da amostra foi calculada usando a meia-vida de 5730 anos, esta idade precisa ser corrigida por meio de sua divisão pela expressão $(5730 \div 5568)$, ou pelo número 1,029 . Esta correção deve ser feira antes da entrada de dados no programa. (...) Os pesquisadores da área perceberam que existiu no

\footnotetext{
10 "Dada a antiguidade das datas de $\mathrm{G}_{4}$ dos tributários do Paraná e Uruguai, o proto-guarani deve ter começado a expandir-se pelo Madeira, fora de Amazônia Central, por volta de, pelo menos, 200 a.C., ou talvez até antes".
} 
passado, até $\mathrm{AD} 1850$, uma diferença na quantidade de carbono radiativo presente na atmosfera dos hemisférios Norte e Sul. Como estamos no Hemisfério Sul, todas as diades radiocarbônicas anteriores a AD 1850 devem ser diminuídas de 24 anos antes de serem calibradas.

Desta forma, diversos cuidados devem ser tomados antes da divulgação das datas como sendo a cronologia efetiva da ocupação dos Guaranis. Neste sentido, as datas aqui apresentadas demonstram as dificuldades de estabelecer, com segurança, o período ou antiguidade deste sítio. Os próximos itens deste capítulo buscam apresentar a dificuldade de se adotar uma única data ou método como válido para inferir a localização temporal da sociedade em questão.

\subsection{As datações obtidas pelo LACIFID ${ }^{11}$}

Neste estudo de caso, optou-se por métodos que contemplassem o material disponível (sobretudo sedimentos e cerâmica), dos quais se obteve um conjunto de dezoito datas em sequiência que convergiam para uma longa e antiga ocupação Guarani no vale do Jacuí. Conforme visto acima, estas não seriam o primeiro conjunto de datas antigas para os sítios Guaranis no sul do Brasil. Pesquisadores de campo de outrora já haviam apontado as datas anteriores a 2000 anos antes do presente como uma realidade empírica dos Guaranis arqueológicos. Em contrapartida, neste sítio buscou-se respaldar o trabalho pelo maior número de datações no mesmo sítio, o que reduziria a margem de erro e a falibilidade dos métodos.

Embora ainda exista, no meio acadêmico, o questionamento por certos pesquisadores sobre a validade da datação por $\mathrm{TL}^{12}$ observa-se que a datação por radiocarbono permanece intocável em sua soberania no quesito falibilidade. Dificilmente vêem-se pesquisadores questionando a contaminação do carvão, os fatores pós-deposicionais e as perturbações pedogênicas. Observa-se que, ainda hoje, as datas são aceitas indiscriminadamente se se enquadrarem dentro dos modelos existentes (Brochado ou Lathrap versus Meggers), mas são sistematicamente refutadas quando ultrapassam os limites considerados "aceitáveis" para os paradigmas em vigor.

Diversas datas de cerâmica, sedimentos e carvão foram constatadas no sítio em questão, tanto na área de descarte (lixeira) quanto na de escavação realizada na várzea do rio (habitação). Os sedimentos coletados para análise são compostos de sedimentos

\footnotetext{
${ }^{11}$ Laboratório de Cristais Iônicos e Filmes Finos e Datação, Instituto de Física, Universidade de São Paulo.

12 Não foram poucos os arqueólogos que, durante o congresso da SAB, em 2003, em São Paulo, questionaram as datas produzidas tanto pelo LACIFID como pela FATEC, o que reforçou a busca pela produção do maior número de datas possíveis.
} 
antropogênicos e não-antropogênicos, extraídos tanto da retificação dos taludes na área de descarte como no perfil realizado nas trincheiras da escavação da várzea. Sendo assim, diversas amostras (ao todo foram 22 amostras de sedimentos e cerâmica) foram datadas, segundo a termoluminescência (TL) e luminescência oticamente estimulada (OSL) no LACIFID. Conforme Watanabe e Sengupta (1997), essas técnicas podem ser utilizadas com precisão para datações de vasos cerâmicos e terras queimadas. Resumidamente, o processo de datação de TL consiste no seguinte procedimento:

$\mathrm{O}$ aquecimento acima de $300^{\circ} \mathrm{C}$ elimina dos grãos de quartzo toda a termoluminescência previamente induzida, isto é, estabelece o marco zero da idade do objeto arqueológico, cuja idade se deseja obter. (...) No caso de vasos cerâmicos dos habitantes pré-históricos, muitos deles foram enterrados intencionalmente ou por processos naturais. A partir do momento em que ele foi enterrado, começa a receber radiações da radioatividade natural da vizinhança. Com isso, os grãos de quartzo começam a acumular termoluminescência. Portanto, se extrairmos grãos de quartzo de uma cerâmica arqueológica, após a separação e lavagens padrões, determinaremos a TL acumulada (WATANABE e SENGUPTA, 1997, p.165).

No caso dos sedimentos, também se pode utilizar a luminescência oticamente estimulada (OSL). "Na luminescência oticamente estimulada, o cristal recebe luz, ao invés de calor, e os elétrons são ejetados e seguem o mesmo caminho como no caso da TL para emitir a luz" (WATANABE e SENGUPTA, 1997, p.166), possibilitando assim a datação dos solos e sedimentos que envolvem o sítio em sua posição crono-estratigráfica. Conforme os mesmos autores, erros de $5 \%$ podem ser esperados.

Existem diversas vantagens da datação por termoluminescência em arqueologia. Neste estudo de caso, a abundância de cerâmica frente às limitadas amostras de carvão, somada à profundidade do sítio reduzir as interferências contemporâneas induziram a utilização de uma datação direta ao invés de privilegiar a datação indireta, como é o caso do $C_{14}$. Araújo (2001, p.93) coloca a questão da seguinte forma:

Esta diferenciação entre nétodos\{ XE "Método" \} de datação direta e indireta é reconhecida em arqueologia, porém, se utilizarmos uma terminologia precisa o problema se torna mais claro. Existem quatro escalas de medida: nominal (classe/grupo), ordinal (ordem/ grau), de intervalo (igualdade de diferenças) e proporcional ou de proporção (relação constante) (Colman et al. 1987, p. 317). Estimativas nominais são atribuições de idade baseadas na equivalência de eventos datados independentemente, utilizando-se de argumentos de ligação. Estimativas ordinais especificam se algo é anterior ou posterior, mas não o quanto. Estimativas de intervalo medem diferenças temporais entre eventos, mas sem ancorá-las a um ponto de referência. Por fim, estimativas de proporção especificam a distância de um evento em relação a um ponto estabelecido no tempo, geralmente o presente. Mais informações são fornecidas à medida que se sobe na escala de nominal para 
proporção, porém geralmente às expensas da precisão devido a um incremento nas exigências necessárias pelo método.

As datas realizadas pelo LACIFID, desta forma, forneciam uma escala de proporção que, em última análise, orientavam a sequiência de ocupação, abandono e reocupação do local. A seqüência de sedimentos retirados dos perfis das escavações e as cerâmicas (Anexo 1: Desenho 6) resultaram em períodos de 710 a 3.500 anos AP (Antes do Presente).

Essas datas retrocedem em alguns milênios às existentes, referentes à ocupação Guarani no sul do Brasil, e devem ser consideradas com extrema cautela, uma vez que ultrapassam - e muito - as datas aceitas para a ocupação Guarani. Noelli (2000) apresenta um quadro com trinta sítios e respectivas datações, em sua maioria $C_{14}$, com médias entre 300 B.P. e 1000 B.P., ocorrendo máximas de $1800 \pm 100$ (Brochado, 1984) e $1870 \pm 100$ (SI-418) (BROCHADO, 1973, apud NOELLI, 1999/2000, p.252). Por outro lado, como citado acima, estas datas não foram calibradas, possibilitando uma margem de erro que deve ser averiguada.

Além disso, estas datas estão publicadas de forma isolada, ou seja, não existem sequiências de datações ou conjuntos de datas a respeito do mesmo sítio. Na maioria dos casos, uma única amostra é datada e seu resultado é acolhido ou não pelo pesquisador. Este problema é ampliado à medida que os pesquisadores escolhem os resultados que serão publicados, rejeitando ou refutando aqueles que não atendem ao modelo de dispersão consagrado.

Como pode ser observado no Desenho 6 (Anexo 1), Milder e Soares (2002) propõem duas ocupações distintas, ou seja, uma recente, na camada superficial, e outra, mais antiga, em profundidade. Este dado confere com a descrição realizada por Ribeiro (1996, p.18), que apresenta desta forma o sítio RS-JC-57:

A profundidade dos sedimentos com sinais de ocupação é rasa, isto é, atinge de 15 a $20 \mathrm{~cm}$. Apenas um local apresenta maior profundidade, mas pouco resta do antigo sítio (erodido pelas águas do rio). Como os sítios estão assentados sobre locais de cultivo, encontram-se praticamente destruídos.

Em face dessa reflexão, é compreensível que o arqueólogo citado não tenha considerado a ocupação dos grupos Guaranis em torno de até $50 \mathrm{~cm}$ de profundidade, não tenha observado que o sítio ficasse em maior profundidade, e não tenha considerado as evidências no talude do rio como um sítio destruído.

Dessa forma, Milder e Soares (2002) consideraram as datas de 710 até 1030 AP obtidas pelo LACIFID como relativas à ocupação superficial (e destruída), na qual os pesquisadores anteriores realizaram coleta de superfície. Essas datas, ao mesmo tempo, estão inseridas no modelo existente para a ocupação Guarani no sul do Brasil e são amplamente 
aceitas. Porém, deve-se observar que, conforme a Tabela 4, as datações citadas são obtidas a partir de fragmentos de cerâmica obtidos na escavação do nível inferior, ou seja, na profundidade de 60 a $80 \mathrm{~cm}$.

Nesta ocupação, foram coletados e datados os sedimentos estéreis imediatamente superiores e inferiores ao NSA, conforme mostra a Tabela 4. Os sedimentos naturais coletados para amostras foram retirados do perfil realizado no talude do rio e na trincheira que delimitava a área de escavação (Anexo 1: Desenhos 4 e 5).

Além dos sedimentos naturais, foram datados sedimentos antrópicos dos sítios RS-JC55 e RS-JC-92, para efeitos de comparação da cronologia de ocupação no vale do rio Jacuí. No caso do sítio, denominado RS-JC-57 por Ribeiro (1991a, 1996), não havia comprometimento das datações realizadas sobre sedimentos, pois as alterações antrópicas recentes não poderiam ter perturbado o local na profundidade das amostras recolhidas.

\subsubsection{As amostras: procedimentos}

As amostras de sedimento antropogênico e natural foram coletadas conforme a orientação do professor doutor Shigueo Watanabe, do Instituto de Física da Universidade de São Paulo (USP). Utilizam-se tubos de PVC rígido, de $50 \mathrm{~cm}$ de comprimento e $50 \mathrm{~mm}$ de abertura, para retirada das amostras de solo e/ou da cerâmica, para não haver incidência de luz solar, a fim de evitar contaminação por reaquecimento das amostras. Considerando que a profundidade do sítio (entre 60 e $120 \mathrm{~cm}$ ) inviabilizava a contaminação por arado mecânico, ${ }^{13}$ a coleta iniciou-se a partir dos perfis realizados no talude (barranca do rio) e na abertura da trincheira realizada com pá mecânica. As amostras de cerâmica foram retiradas da área escavada, sempre sendo consideradas as dimensões necessárias para realização do processo (fragmentos de, no mínimo, 7x7 cm).

As datações realizadas no LACIFID da USP, sob responsabilidade técnica do professor Watanabe, foram testadas duas ou três vezes, a título de recalibragem. A Tabela 4 apresenta as datas obtidas pelo Laboratório de Vidros e Cristais Iônicos, LACIFID (ver Anexo 1: Desenho $6)$.

Tabela 4 - Datas obtidas por TL e OSL no Laboratório de Vidros e Cristais Iônicos, LACIFID, Instituto de Física, Universidade de São Paulo, USP. Os sítios RS-JC-55 e RS-JC-92 aparecem no

\footnotetext{
${ }^{13} \mathrm{O}$ arado mecânico atinge espessura do solo não superior a $40 \mathrm{~cm}$.
} 
Mapa 3 como sítio 25 e sítio 2, respectivamente. Obs: As datas que não apresentam probabilidade de erro (com desvio para mais ou menos) foram repassadas desta forma pelo LACIFID

\begin{tabular}{|c|c|c|c|}
\hline Sítio & $\begin{array}{c}\text { Sedimento natural } \\
\text { Idade AP } \\
\end{array}$ & Local & Data \\
\hline ROPKE & 4090 & $\begin{array}{l}\text { Amostra III - sedimento - Setor I } \\
X=2,65, Y=4,80\end{array}$ & $30 / 01 / 2000$ \\
\hline ROPKE & 4940 & Prof. $60 \mathrm{~cm}$ - Perfil da trincheira & 09/07/1999 \\
\hline ROPKE & 4979 & $\begin{array}{l}\text { Amostra I - sedimento-Setor I } \\
X=0,20-0,50 \quad Y=5,35\end{array}$ & $30 / 01 / 2000$ \\
\hline Sítio & $\begin{array}{l}\text { Sed. antropogênico } \\
\text { Idade AP }\end{array}$ & Local & Data \\
\hline RSJC 55 & 960 & NSA (SUPERIOR) & \\
\hline RSJC 55 & 1030 & Trincheira & \\
\hline RSJC 92 & 2230 & NSA & \\
\hline ROPKE & 2578 & $\begin{array}{c}\text { Amostra II - sedimento - Setor I } \\
X=0,20 / 0,60 Y=8,00 \text { perfil trincheira }\end{array}$ & $30 / 01 / 2000$ \\
\hline RSJC 55 & 2.975 & Núcleo de solo antropogênico (NSA) & \\
\hline ROPKE & $3870 \pm 350$ & amostra VII - setor C & $01 / 11 / 00$ \\
\hline ROPKE & $3950 \pm 400$ & Amostra VII - setor C & $01 / 11 / 00$ \\
\hline Sítio & $\begin{array}{l}\text { Sedimento lixeira } \\
\text { Idade AP }\end{array}$ & Local -Lixeira (sedimento) & Data \\
\hline ROPKE & 5210 & Prof. $2,10 \mathrm{~m}$ & $09 / 07 / 1999$ \\
\hline ROPKE & 6685 & Prof. $2,50 \mathrm{~m}$ & $09 / 07 / 1999$ \\
\hline ROPKE & $7000-8000$ & Prof. $8 \mathrm{~m}$ & \\
\hline Sítio Ropke & $\begin{array}{l}\text { Cerâmica } \\
\text { Idade AP }\end{array}$ & Amostras de Cerâmica & Data \\
\hline Amostra 5 & $710 \pm 50$ & Peça 759 - catálogo 277 & $13 / 12 / 2001$ \\
\hline Amostra 2 & $750 \pm 60$ & Peça 233 - catálogo 277 & $13 / 12 / 2001$ \\
\hline Amostra 4 & $2200 \pm 200$ & Peça 1350- catálogo 277 & $13 / 12 / 2001$ \\
\hline Amostra 1 & $1500 \pm 100$ & Peça 248 - catálogo 277 & $13 / 12 / 2001$ \\
\hline Amostra 3 & $2300-2500$ & Peça 705 - catálogo 277 & $13 / 12 / 2001$ \\
\hline- & 3500 & Setor III Paralelo ao eixo y $=8,00$ & $01 / 02 / 2000$ \\
\hline- & $3600-4000$ & Nível I da lixeira & $18 / 10 / 2000$ \\
\hline- & $4000-5000$ & Setor $\mathrm{C}-1,20 \mathrm{~m}$ de profundidade & \\
\hline
\end{tabular}

Dessa forma, poder-se-ia considerar a existência de duas ocupações Guaranis no rio Jacuí. Se for observada a margem de erro prevista nas datações (conforme WATANABE e SENGUPTA, 1997), de 5 a 8\%, tem-se, no máximo, 280 anos sobre a data mais antiga (3500 $\pm 280)$ e 56 anos sobre a data mais recente $(710 \pm 56$ ), o que não invalida a antiguidade dos artefatos. Se forem levadas em conta, ainda, as datas realizadas para outros sítios na mesma várzea com sedimentos antropogênicos (sítios RS-JC-92 e RS-JC-55), poder-se-ia inferir que a ocupação Guarani, no sítio, deveria ter alcançado sua maior relevância entre os anos 1500 e 2500 anteriores ao presente.

A utilização das datas realizadas pelo LACIFID já demonstrou, em outras oportunidades, grande coerência entre os dados preexistentes para a arqueologia do estado do 
Rio Grande do Sul. A escavação de um cerrito no distrito de Santa Margarida, município de São Gabriel (RS), apresentava evidências de ocupação Guarani, da Tradição Vieira e de grupos caçadores em seqüência estratigráfica. As datações, realizadas através de amostras de sedimentos e cerâmica, indicaram ocupação em 2600 A.P., 2400 A.P. (caçadores), 1370 A.P. para a cerâmica Vieira e 175 A.P. para a cerâmica Guarani.

Em outro caso, foram escavadas duas urnas funerárias no município de São Martinho da Serra (RS), que continham restos humanos e contas de colar de vidro. As datas para o ajuar funerário, segundo datação TL realizada pelo LACIVID-USP, determinaram o período entre 1530 e 1620 desta Era (SOARES e MILDER, 2003). Estas datas estão em perfeita consonância com o período das primeiras missões jesuíticas na província jesuítica do Tape que, a partir de 1627, fundaram reduções na bacia dos rios Vacacaí e Ibicuí (o sítio onde foram resgatadas as urnas encontra-se próximo às nascentes do rio Vacacaí).

No entanto, o conjunto mais amplo de datações realizadas para o sítio RS-JC-57 demonstrou que algumas destas datas não podem ser consideradas válidas, e outras que devem ser tomadas com extrema cautela, em face de outras análises terem sido realizadas e outros resultados obtidos.

\subsection{Outras datações obtidas}

As datas obtidas por termoluminescência (TL), realizadas pelo Laboratório de Vidros e Datação da Faculdade de Tecnologia de São Paulo (FATEC), foram realizadas sobre oito fragmentos cerâmicos, dois provenientes da área de descarte, dois fragmentos da trincheira junto à habitação, um da habitação e dois fragmentos de outros sítios próximos (uma amostra não pode ser datada). Considerando a possibilidade de existirem duas ocupações distintas, conforme Milder e Soares (2002), o novo conjunto de datas revelaria se existiu contemporaneidade entre a área de descarte e a ocupação do sítio superficial (que estava destruído) ou a habitação escavada de que trata este trabalho. Os resultados obtidos são apresentados na Tabela 5 .

Tabela 5 - Datações realizadas pela FATEC

\begin{tabular}{|c|c|c|c|c|}
\hline $\begin{array}{l}\text { Código } \\
\text { do LVC }\end{array}$ & Amostra & P(Gy) & DA $\left(10^{-6}\right.$ Gy/ano $)$ & Idade BP (anos) \\
\hline $940^{a}$ & $\mathrm{~N}^{\circ} 1828$ lixeira & 1,71 & $1248 \pm 28$ & $1370+160$ \\
\hline 940b & $\mathrm{N}^{\circ} 1828$ lixeira & 1,76 & $1430+36$ & $1200 \pm 65$ \\
\hline $941^{\mathrm{a}}$ & $\mathrm{N}^{\circ}$ 257- trincheira & 1,46 & $1315 \pm 33$ & $1100 \pm 78$ \\
\hline 941b & $\mathrm{N}^{\circ} 257$ - trincheira & 1,20 & $1174+27$ & $1000 \pm 240$ \\
\hline 1040 & Habitação ropke & 2,51 & $1481 \pm 39$ & $1700 \pm 210$ \\
\hline
\end{tabular}




\begin{tabular}{c|cc|cc}
\hline 1041 & Sítio Scapini & 2,0 & $1238 \pm 31$ & $1600 \pm 200$ \\
\hline 1042 & Sítio Glanzel & 0,99 & $1546 \pm 39$ & $640 \pm 80$ \\
\hline 1043 & Sítio Alberstaat & 1,42 & $1297 \pm 36$ & $1100 \pm 140$ \\
\hline
\end{tabular}

O conjunto de datas obtido pela FATEC não resolveu o problema proposto, qual seja, de determinar se havia contemporaneidade entre a área de descarte e os sítios da várzea.

Por outro lado, estas datas corroboram as datas aceitas para os grupos Guaranis no vale do rio Jacuí, que estipulam a ocupação deste grupo ao redor do V século da Era Cristã para a ocupação do vale (conforme discussão acima, breve histórico das datações em sítios Guaranis).

É importante destacar, porém, que estas datas não são compatíveis com aquelas realizadas pelo LACIFID, no qual o conjunto de datações realizadas para a cerâmica recua a ocupação para mais de dois mil anos antes do presente. Descartando-se as datas que, por sua antiguidade, não estariam dentro do modelo existente, é preciso ater-se ao conjunto de datações que apresentam convergência. No entanto, as datas realizadas sobre cerâmica pelo LACIFID ou são mais recentes (Amostra $5=710 \pm 50 \mathrm{AP}$ e Amostra $2=750 \pm 60 \mathrm{AP}$ ) ou mais antigas (Amostra $4=2200 \pm 200$; Amostra 1- $1500 \pm 100$ ), acrescentando que as amostras tratadas são de fragmentos cerâmicos do mesmo sítio em discussão.

A comparação entre os resultados obtidos nos dois laboratórios, considerando que o método aplicado é o mesmo, é um argumento para discutir os resultados alcançados neste sítio; porém, um dos problemas enfrentados para a comparação de nossos resultados com aqueles de outros sítios que realizaram datações TL nestes laboratórios é que dificilmente são realizadas e/ou publicadas mais de uma datação para o mesmo sítio. Sendo assim, a totalidade das datações obtidas é passível de questionamento frente ao leque de possibilidades de resultado apresentado. Sendo assim, optou-se pela realização de outra datação, desta vez utilizando-se o método de Carbono radioativo ou radiocarbono.

\subsection{Datações por $C_{14}$}

$\mathrm{Na}$ área de habitação foram registradas pelo menos duas grandes fogueiras, das quais foram possíveis retirar amostras para datação pelo método de radiocarbono. A contagem de Carbono radioativo foi realizada no Beta Analytic Radiocarbon Datin Laboratory, EUA (número de laboratório Beta 181 184). Esta amostra foi datada em $470 \pm 50$ antes do presente, 
o que corresponderia, com 95\% de probabilidade, a uma ocupação entre os anos de 1400 e 1490 da Era Cristã.

Essa data questiona frontalmente as datações obtidas pelos métodos anteriores. Neste ponto, cabe o questionamento sobre as datações realizadas a partir do Carbono. Araújo (2001, p.94) expõe argumentos que permitem refletir sobre a validade destes resultados:

$\mathrm{O}$ método do $\mathrm{C}_{4}$ possui uma maior precisão técnica, porém é necessário ter-se em mente que a vantagem da termoluminescência envolve a ausência da necessidade de calibração. Calibração é uma questão de acurácia, mas é realizada às expensas da precisão. Datações de radiocarbono, ao contrário da termoluminescência, necessitam ser calibradas e, às vezes, as curvas de calibração são bastante planas, ou uma data intercepta pontos diferentes da curva, resultando em datas cobrindo um grande período de tempo. Acresce-se a isto um problema raramente encarado de frente na Arqueologia: o que se está datando por radiocarbono só pode ser relacionado a um evento arqueológico por meio de um argumento de ligação. Fragmentos de carvão são sempre associados a artefatos, ou ao que quer que seja, por uma suposição (geralmente implícita) que leva em conta proximidade e/ou posição estratigráfica. O que está no mesmo 'nível arqueológico' tem a mesma idade. Esta suposição é demonstradamente frágil, conforme exposto por inúmeros autores.

O que parece necessário ressaltar é que, diante do leque de datas realizadas e da vasta amplitude temporal que as mesmas indicam, uma série de alternativas e/ou opções devem ser levadas em conta para explicar este sítio em todo o seu contexto. Não será apresentada, neste trabalho, uma data definitiva para a ocupação dos Guaranis no sítio RS-JC-57; o que será apresentado é um período ou faixa temporal em que as evidências de ocupação são maiores e, desta forma, podem ser associadas ao estabelecimento desta população no vale do rio em questão.

Na Tabela 6 apresenta-se um resumo dos resultados obtidos a partir das análises realizadas pelo LACIFID e pela FATEC.

Tabela 6: tabela-resumo das datações obtidas.

\begin{tabular}{cccc|c|}
\hline Data Era Cristã & Laboratório & Data Lab. & Local/ peça & Objeto datado \\
\hline 3000 a 2000 AC & LACIFID & $4000-5000$ & Setor C $-1,20 \mathrm{~m}$ de profundidade & Cerâmica \\
\hline 2979 AC & LACIFID & 4979 & Amostra I- Setor I X= 0,20 Y= 5,35 & Sedimento natural \\
\hline 2949 AC & LACIFID & 4940 & Prof. 60 cm - Perfil da trincheira & Sedimento natural \\
\hline 2090 AC & LACIFID & 4090 & Amostra III Setor I X=2,65, Y=4,80 & Sedimento natural \\
\hline $1950 \pm-400$ AC & LACIFID & $3950 \pm-400$ & Amostra VII - setor C & Sed. Antropogênico \\
\hline $1870 \pm-350$ AC & LACIFID & $3870 \pm-350$ & amostra VII - setor C & Sed. Antropogênico \\
\hline 2000 e 1600 AC & LACIFID & $3600-4000$ & Nível I da lixeira & Cerâmica \\
\hline 1500 AC & LACIFID & 3500 & Setor III Paralelo ao eixo y = 8,00 & Cerâmica \\
\hline 975 AC & LACIFID & 2.975 & RSJC 55 - NSA & Sed. Antropogênico \\
\hline 578 AC & LACIFID & 2578 & Amostra II - Setor I X= 0,20 Y= 8,00 & Sed. Antropogênico \\
\hline 230 AC & LACIFID & 2230 & RSJC 92- NSA & Sed. Antropogênico \\
\hline 300 e 500 AC & LACIFID & $2300-2500$ & Amostra 3 - Peça 705 - catálogo 277 & Cerâmica \\
0 DC e 400 AC & LACIFID & $2200 \pm-200$ & Amostra 4- Peça 1350 - catálogo 277 & Cerâmica \\
\hline
\end{tabular}




\begin{tabular}{|c|c|c|c|c|}
\hline $300 \pm 210 \mathrm{DC}$ & Fatec 1040 & $1700 \pm 210$ & Habitação ropke & Cerâmica \\
\hline $400 \pm-200 \mathrm{DC}$ & Fatec 1041 & $1600 \pm 200$ & Sítio Scapini & Cerâmica \\
\hline $500 \pm 100 \mathrm{DC}$ & LACIFID & $1500 \pm-100$ & Amostra 1 - Peça 248 - catálogo 277 & Cerâmica \\
\hline $630 \pm-160 \mathrm{DC}$ & Fatec $940^{\mathrm{a}}$ & $1370 \pm 160$ & $\mathrm{~N}^{\circ} 1828$ lixeira & Cerâmica \\
\hline $800 \pm 65 \mathrm{DC}$ & Fatec 940b & $1200 \pm 65$ & $\mathrm{~N}^{0} 1828$ lixeira & Cerâmica \\
\hline $900 \pm-78 \mathrm{DC}$ & Fatec 941 ${ }^{\mathrm{a}}$ & $1100 \pm 78$ & $\mathrm{~N}^{0}$ 257- trincheira & Cerâmica \\
\hline $900 \pm 140 \mathrm{DC}$ & Fatec 1043 & $1100 \pm 140$ & Sítio Alberstaat & Cerâmica \\
\hline $1000 \pm-240 \mathrm{DC}$ & Fatec 941b & $1000 \pm 240$ & $\mathrm{~N}^{\circ}$ 257- trincheira & Cerâmica \\
\hline $970 \mathrm{DC}$ & LACIFID & 1030 & RSJC 55 -Trincheira & Sed. Antropogênic \\
\hline $1040 \mathrm{DC}$ & LACIFID & 960 & RSJC 55 NSA (SUPERIOR) & Sed. Antropogênico \\
\hline $1250 \pm-60 \mathrm{DC}$ & LACIFID & $750 \pm-60$ & Amostra 2- Peça 233 - catálogo 277 & Cerâmica \\
\hline $1290 \pm-50 \mathrm{DC}$ & LACIFID & $710 \pm-50$ & Amostra 5 - Peça 759 - catálogo 277 & Cerâmica \\
\hline $1360 \pm-80 \mathrm{DC}$ & Fatec 1042 & $640 \pm 80$ & Sítio Glanzel & Cerâmica \\
\hline $1530 \pm-50 \mathrm{DC}$ & Beta & $470 \pm-50$ & Habitação Ropke & carvão \\
\hline
\end{tabular}

Conforme pode ser observado na Tabela 6, as datas do sítio RS-JC-57 convergem para uma ocupação que pode ser estabelecida entre os séculos III e XIII da Era Cristã. Neste trabalho, considerando a ocupação do vale como um todo, não se podem adotar datas tão antigas como a de 2000 AC ou mesmo anteriores. Por outro lado, este intervalo escolhido além de ser coerente com os outros dados já publicados, poderá ser revisto com maior precisão de acordo com dados que estão por ser conhecidos.

Ainda se aguardam outras datas que serão processadas, como amostras de carvão, ossos humanos e, em especial, um grão de milho. Em colaboração com a Doutoranda Patrícia Goulart Bustamante, do Embrapa- RJ, está sendo analisado o DNA nuclear de um grão de milho carbonizado encontrado na escavação. Espera-se que esta análise ajude em resultados mais conclusivos em relação à data da ocupação do sítio.

No entanto, fica registrado um alerta para que uma única datação não seja considerada definitiva ou irrevogável, sob pena de incorrer-se em erro involuntário. Antes, deve-se ter cautela com um único método de datação e as consequiências de cada resultado obtido. Não cabe a esta tese declinar sobre um ou outro método, mas apontar que, frente aos dados obtidos, recai sobre o arqueólogo a escolha de uma data que seja corroborada pelo maior número de elementos que atestem a idade dos artefatos. Ainda, pretende-se que estas datas ampliem a discussão sobre os modelos e paradigmas aceitos, tendo em vista que a pesquisa se encontra em andamento. 


\section{DETERMINANDO O USO DO ESPAÇO: ANÁLISE DOS ARTEFATOS E SUA DISTRIBUIÇÃO NO SÍTIO}

Neste capítulo pretende-se abordar a análise dos artefatos e sua distribuição no espaço a fim de determinar o seu uso e as relações sociais e econômicas que ocorreram no local. Continuar-se-á seguindo os pressupostos de Leroi-Gourhan e Brézillon (1966, 1972), pois se acredita que é possível inferir os usos do espaço pré-histórico a partir da distribuição e associação dos artefatos. Como afirmam esses autores (1966, p. 324-325),

La position dês matériaux a elle aussi commandé l'exploitation: le fait le plus évident étant leur conservation dans la situation d'abandon par les Magdaléniens, l'interprétation a été essentiellement cartographique. Chaque fois qu'il a été possible, des 'courbes de groupement', ont été établies, réunissant entre eux les vestiges de même nature et séparé par moins de vingt centimètres. L'avantage de ce procédé est de faire ressortir plus clairement ce qui peut avoir subsisté de l'évolution des différentes activités à l'interieur de l'habitat. ${ }^{1}$

Desta forma, a ênfase dada nesta análise é atingir o uso social dos núcleos de solo antropogênico. Por uso social, compreendem-se as relações sociais familiares e extrafamiliares $^{2}$ que se verificam no espaço da habitação, uma vez que não se abordará esta análise na área de descarte, pois se considera que esta não apresenta ordenação espacial.

Cabe salientar que a área de descarte já foi descrita no capítulo dois. É importante ressaltar, no entanto, que a disposição das lentes de solo antropogênico, a presença de artefatos somente nestes NSA e a localização no taludo do rio, bem como a disposição vertical das lentes no talude confirmam a ocupação longa e reocupação do local por duas sociedades temporalmente distantes. Além disso, os NSA apontam para uma densidade de cultura material que remete necessariamente à ocupação, seja na área de descarte, no talude de rio, ou na habitação.

Sendo assim, neste capítulo abordar-se-á a distribuição dos artefatos, conforme os distintos testemunhos arrolados no capítulo dois (ver Anexo 4: Gráfico 1); a descrição desses artefatos já está referida no capítulo supra, de forma que, neste capítulo, tratar-se-á de como o

\footnotetext{
1 “A posição dos materiais em si comandam a exploração: o fato mais evidente era sua conservação na situação de abandono pelos Magdaléniens, a interpretação foi essencialmente cartográfica. Cada vez que era possível, as 'curvas de agrupamento' foram estabelecidas, reunido entre elas os vestígios de mesma natureza e separados por menos de vinte centímetros. A vantagem deste procedimento é de fazer ressaltar mais claramente o que pode ter subsistido da evolução das diferentes atividades no interior da habitação."

2 Para uma descrição das diversas relações sociais Guaranis no período histórico e protohistórico, ver Soares (1997).
} 
espaço foi usado, delimitado pelos artefatos. Serão discutidos, ainda, alguns elementos pertinentes ao material lítico e cerâmico (distribuição dos testemunhos líticos, ver Anexo 4: Gráficos 2 e 4; para a totalidade dos testemunhos cerâmicos, ver, no mesmo Anexo 4: Gráficos 26 e 28), no que se refere a uma abordagem funcional. A distribuição dos testemunhos do sítio RS-JC-57 será apresentada por setores, embora se acredite que, inequivocamente, se trata de um mesmo sítio. Em razão de a escavação ter sido conduzida em momentos diferentes e por equipes diferentes, os Gráficos sempre serão apresentados em dois conjuntos, a saber, do setor 1 e dos setores III a VI (as grandes áreas em branco no setores V e VI devem-se à manutenção de blocos testemunho que não foram escavados pelas equipes) (ver Anexo 2: Foto 15).

Conforme citado no capítulo dois, os tipos de testemunhos adotados neste trabalho são os seguintes:

- Testemunhos brutos;

- Testemunhos modificados;

- Testemunhos manufaturados;

- Testemunhos fugazes;

- Testemunhos discretos;

- Testemunhos negativos.

\subsection{Testemunhos brutos - distribuição}

A distribuição dos blocos de basalto e arenito apresenta diferentes comportamentos, conforme a matéria-prima. Pode-se afirmar que os blocos de basalto estão sempre associados àqueles utilizados sobre as fogueiras e fogões, onde estas fazem papel de termóforas ou pedras de suporte. Caso semelhante encontra-se descrito em Schmitz et al. (1990, p.15) sobre a presença de peças sem alteração, denominado "material lítico não modificado intencionalmente e não usado". As distribuições dos blocos de basalto e glabro facilitam a delimitação das fogueiras, uma vez que estas não são circundadas com pedras.

Os blocos de basalto sem modificações são testemunhos da ação da correnteza do rio, que, ao contrário de marcas de uso ou utilização, apresentam-se em seu estado natural, com forma de grandes seixos ou blocos rolados pelo rio. Este dado aponta para um rio lótico, como citado no capítulo dois, no qual a correnteza é forte a ponto de produzir e locomover estes testemunhos. Deve-se observar que, sendo uma planície de inundação, a área poderia ser sido 
objeto de enchentes que carreariam o material. No entanto, o local do sítio não é atingido pelas enchentes, como atestam os testemunhos orgânicos, que teriam sido levados em caso de o sítio ter sido atingido.

Aqui também devem ser incluídos os seixos de basalto que não apresentam sinais de modificação, conforme exposto no capítulo dois. Reitera-se que não se pode afirmar que esses seixos não foram utilizados, mas não apresentam sinais visíveis de uso. Assim, mesmo que essas peças tivessem sido utilizadas (caso contrário não estariam presentes no sítio), não apresentam sinais de preparação, manufatura ou modificação, razão pela qual foram classificadas em testemunhos brutos (ver Anexo 4: Gráficos 6 e 7).

Os blocos de arenito sem utilização, conforme citados no capítulo dois, distribuem-se aleatoriamente nas áreas escavadas, não apontando nenhuma concentração ou local preferencial de armazenamento destes objetos. Espalhados aleatoriamente, não indicam espacialidade reconhecível, pois se encontram acompanhando as áreas de terra enegrecidas pela ação do fogo. Por outro lado, não se limitam a estas, uma vez que no Gráfico de distribuição estes artefatos estão dispersos por toda as áreas escavadas (Anexo 4: Gráficos 8 e 9).

Desta forma, pode-se afirmar que esses testemunhos brutos foram levados ao sítio pela ação humana, com objetivos diversos que foram (ou não) levados a cabo, como será visto adiante.

\subsection{Testemunhos modificados - distribuição}

A distribuição dos blocos de basalto modificados pela ação do calor apresenta uma uniformidade e um padrão nos setores escavados. Schmitz et al. (1990, p.16) utilizam o termo "pedras de fogão" para descrever as peças com alteração provocada pelo calor: "estes seixos

possuem cicatrizes de desprendimento de fragmentos devido ao aquecimento". Essas termóforas estão associadas à dispersão da mancha escura das fogueiras, fogos e fogões, no mais das vezes dentro destes. Estes testemunhos demarcam, mas não delimitam fogueiras, fogos ou fornos. É provável que seu uso estivesse associado às atividades que envolvessem combustão, preparação dos alimentos e confecção de artefatos líticos manufaturados (ver Anexo 4: Gráficos 10 e 11).

Os seixos de basalto alterados pelo fogo no sítio RS-JC-57 apresentam as mesmas cicatrizes descritas por Schmitz et al. (1990, p.16) no sítio de Candelária: 
Estes fragmentos possuem como característica principal as cicatrizes de destacamento pelo fogo; possuem também uma forte alteração (oxidação) acompanhada de cinzas, provocadas pelo contato com o mesmo, na superfície externa. Há um grande predomínio de fragmentos de pedra de fogão de basaltóides sobre os de arenito.

Da mesma forma, o glabro, uma vez que se encontra alterado pelo fogo e não possui propriedades de lascamento pode ser associado às áreas de combustão e fogos, ou como suporte de panelas, conforme sugerido por Schmitz et al.(1990, p.17). O glabro, segundo esses autores, poderia ser classificado como basaltos vesiculares, ou seja, que apresentam vesículas ou incrustações de outras rochas, que facilitaria sua quebra ante a ação do fogo. A distribuição do glabro segue as áreas de combustão, delimitadas às áreas de terra enegrecida pelo fogo (ver Anexo 4: Gráficos 12 e 13).

Os locais de concentração das termóforas pressupõem a localização das áreas de combustão. Neste sentido, podem ser observadas duas ou três grandes áreas, uma no setor $1 \mathrm{e}$ outras duas nos setores III a VI. Em relação à ocupação humana, talvez se trate, provavelmente, de dois ou três núcleos residenciais, haja vista a concomitância com outros fatores, como a distribuição dos outros artefatos. Embora o Gráfico da dispersão das termóforas não possibilite nenhuma afirmação isolada, ao se associar com outros elementos, como o conjunto com os núcleos (com sinal de queima), a presença de carvões e material cerâmico, levam a crer que estas áreas são os centros de atividades domésticas neste espaço habitacional.

\subsection{Testemunhos manufaturados}

A abordagem que será apresentada aqui visa facilitar a compreensão dos artefatos, portanto, adotar-se-á a divisão dos testemunhos manufaturados por matéria-prima, a fim de se obter uma visão que contemple os aspectos de uso de cada uma delas. Por exemplo, a classificação lasca pode ter uso de cortar, raspar, furar, alisar, conforme a utilização que o artesão empregue. Ao contrário, a determinação de uma função delimitaria o rol de usos da mesma peça. A distribuição da totalidade das peças líticas pode ser observada no Anexo 4 (Gráficos 2 e 4).

\subsubsection{Material lítico: arenito}

O objetivo de apresentar a distribuição dos artefatos segundo a matéria-prima ao mesmo tempo em que se apresenta a funcionalidade é buscar inferir os usos do espaço dentro 
da área que se denominou habitação. Sendo assim, buscar-se-á demonstrar que a disposição dos artefatos, embora sabidamente não estejam em seu local exato de abandono, pode auxiliar na interpretação dos mesmos.

A apresentação e discussão a respeito dos possíveis usos dos artefatos encontram-se no capítulo dois. Aqui, pretende-se demonstrar que as atividades ocorriam em maior intensidade em redor das fogueiras, haja vista a distribuição dos testemunhos concentrarem-se ao redor destas. A passagem de Leroi-Gourhan e Brézzillon (1996, p.333) é elucidativa na relação entre distribuição de testemunhos e determinação de estruturas de habitação:

Le groupement des vestiges de sílex autour dês foyer et le long des limites de h'habitat semble par conséquent marquer la place d'une struture trilobée, née de l'imbrication de trois habitations ovales. Chacune de ces habitations aurait comporté un foyer placé à l'entrée. La manipulation $d u$ silex se serait principalement faite près de chacun des foyers. ${ }^{3}$

Desta forma, o que se propõe é que o cruzamento entre a distribuição dos diversos testemunhos permitem a delimitação dos espaços domésticos, bem como dos núcleos familiares que compunham esta habitação. Neste sentido, a distribuição de todos os testemunhos manufaturados aponta para três conjuntos de concentrações que podem ser determinantes para a delimitação dos espaços domésticos de três fogueiras e, conseqüentemente, três famílias nucleares ao redor de seus respectivos locais de combustão.

Ao observar a distribuição dos afiadores em canaleta, vê-se que estes não estão na área de maior concentração de material cerâmico ou junto ao "forno" ou "fogueira com depressão côncava". Ao contrário, parece que os afiadores "margeiam" as fogueiras, como se os objetos ou artefatos em confecção fossem ao fogo para melhor manipulação (ver Anexo 4: Gráficos 14 e 15). Assim como em Pincevent, a distribuição dos artefatos de sílex permitem a inferência dos locais de uso e a posição dos artesãos (op.cit, p. 329). Acredita-se que a distribuição dos afiadores e dos blocos de arenito sem utilização permite inferir que as atividades eram realizadas ao redor do fogo, provavelmente com as pessoas sentadas.

Já não se pode afirmar o mesmo em relação aos blocos polidos de arenito (aqui será tratado apenas dos blocos partidos, não dos seixos de arenito). Sua distribuição avança sobre a área da fogueira e adjacências, sem ordenação espacial visível. Mas, ao mesmo tempo, observa-se que a sua distribuição dá-se em torno das áreas denominadas de fogueira (ver Anexo 4: Gráficos 16 e 17).

\footnotetext{
3 "O agrupamento de vestígios de sílex ao redor dos fogões e ao longo dos limites da habitação parecem, portanto, marcar o local de uma estrutura tripartida, nascida da imbricação de três habitações ovais. Cada uma destas habitações comportavam um fogo colocado à entrada. A manipulação do sílex era principalmente feita perto de cada um dos fogos."
} 
O uso desses blocos com sinal de polimento permanece uma incógnita. Conforme foi exposto no capítulo dois, o aumento em lupa binocular não permitiu inferências a respeito do uso. No entanto, sua distribuição aponta, novamente, para atividades em torno das fogueiras. Se por um lado não se pode inferir o uso ao qual foi destinado, por outro, acredita-se que, juntos com os outros testemunhos, fica reforçada a idéia de que as atividades se concentram em torno das áreas de combustão, sejam elas fogueiras, fogos ou fogões.

\subsubsection{Material lítico: calcedônia}

Se consideradas todas as lascas de descorticamento, lascas corticais, detritos e refugos que têm sinais de fogo sobre a sua superfície, ter-se-á uma grande quantidade de material, numericamente falando, mas certamente pertencentes a um número bastante reduzido de seixos que estavam em preparação para lascamento que foram abandonados (ver Anexo 4, Gráficos 22 a 25) .

Analisados separadamente, as grandes partes de seixos de calcedônia podem assemelhar-se a núcleos esgotados; quando, na verdade, a partir da remontagem destas peças, pôde-se observar que perfazem alguns poucos seixos, abandonados na fogueira. ${ }^{4} \mathrm{Se}$ forem consideradas estas partes como núcleos, ter-se-iam mais de trinta núcleos utilizados quando a remontagem dos seixos revela quatro grandes blocos parcialmente remontados (aproximadamente metade do bloco original), doze conjuntos com peças encaixadas e outros treze compostos de peças que não se encaixam, mas pertencem ao mesmo núcleo. ${ }^{5}$ Uma vez que o objetivo aqui não é a análise em profundidade do material lítico, sua cadeia operatória, desde sua coleta até o descarte, continuar-se-á o processo de análise após o término desta tese.

A dispersão das partes dos núcleos pode ser observada no Anexo 4 (Gráficos 18 a 21), o que poderia representar novas tentativas de aproveitamento de material, de lascamento ou uso para outra função diversa do lascamento, como apoio de peças ou de vasilhas. Outra possibilidade é que os processos depois do abandono ou pós-deposicionais tenham dispersado o material arqueológico. No entanto, a força dos eventos naturais deve ser relativizada, uma vez que diversos materiais orgânicos (como ossos, sementes e carvões) foram registrados, o

\footnotetext{
4 Foram identificados vinte e nove conjuntos classificados como núcleos, sendo que dez foram remontados, colados e sua localização é exata (ver Anexo 4, Gráficos 12, 13, 14 e 15). Outros doze núcleos são compostos por uma única peça.

5 Foram considerados elementos como matéria-prima, tipo de córtex, coloração, dimensões, entre outros elementos, para identificar as peças que compõem o mesmo núcleo.
} 
que permite pensar que, caso houvesse ação de arrastamento destes artefatos, os mais leves seriam os primeiros a serem dispersos.

Estes seixos foram considerados como testemunhos manufaturados uma vez que, além da alteração promovida pelo fogo, são nítidos os pontos de percussão sobre os blocos remontados, sinais de que houve tentativas de produção de lascas que, por outras características físicas, não foram aproveitadas (ver Anexo 3: Fotos 2, 3, 4 e 5).

Além disso, a remontagem dos núcleos proporcionou a verificação das etapas de preparação dos mesmos, com a escolha dos blocos de calcedônia, o aquecimento em fogueira e posterior quebra destes. A passagem de Goldmeier e Schmitz (1989, p.389) é elucidativa:

Os nódulos de calcedônia são recolhidos nas corredeiras do rio. O tamanho destes nódulos é variável, mas no geral está por volta do tamanho de amostra-demão, ou pouco maiores. A característica destes nódulos de calcedônia é que eles são difíceis de lascar; para chegar à matéria-prima que precisava o homem préhistórico fez uso de uma técnica de retalhamento, costumeiramente chamada téc nica bipolar.

No caso do sítio RS-JC-57, foi observado ainda o aquecimento dos núcleos para facilitar o lascamento, embora não tenha sido utilizada nenhuma lasca das peças remontadas, o que permite pensar que o processo não ocorreu conforme o planejamento do artesão. Ao mesmo tempo, é importante salientar que esta atividade está ocorrendo dentro do espaço habitacional. Desta forma, pode-se levantar algumas hipóteses: a) o material lascado era confeccionado dentro da casa (por causa dos detritos e lascas não utilizadas estarem na área de fogueiras), esta idéia se contrapõe à utilização de espaços externos para confecção de artefatos líticos em áreas de atividade fora da residência; b) o material lítico poderia ser confeccionado por ambos os sexos, e, neste caso, os refugos poderiam ser resultado de atividade feminina sem domínio da matéria-prima, haja vista a quantidade de material não utilizado, o que demonstra inaptidão ao lascamento da calcedônia ou confecção ocasional.

Essas hipóteses devem ser testadas através de uma profunda e sistemática análise do lítico Guarani, o que é uma atividade bastante obstruída pela pequena quantidade de publicações que tratam da distribuição espacial do lítico em amplas áreas escavadas. Ademais, não é objetivo deste trabalho uma profunda análise do lítico, mas apontar para a pequena quantidade de artefatos utilizados frente à quantidade de testemunhos manufaturados.

Assim, as peças líticas com sinal de uso (lasca de riolito retocada, lasca de calcedônia com desgaste por uso, dois fragmentos de lâminas polidas de basalto e os afiadores de canaleta, ver Anexo 3: Fotos 6 e 8) são numericamente insignificantes frente às mais de 2.600 peças líticas escavadas. Desta forma, é necessário observar que durante os anos de coleta 
assistemática, aleatória e seletiva, realizadas por pesquisadores, acadêmicos ou não, pouca importância foi dada aos diferentes testemunhos líticos (brutos, modificados, manufaturados, discretos) presentes nos sítios Guaranis, disseminando-se a idéia de que estes horticultores pouco utilizariam os recursos líticos à disposição.

Deve-se observar outro ponto em relação à distribuição dos testemunhos manufaturados. A dispersão dos núcleos líticos sugere que a movimentação de algumas peças foi bastante intensa (por exemplo, no Anexo 4, núcleo 2 no Gráfico 19 e núcleo 3 no Gráfico 18; ver também Gráficos 20 e 21). Neste caso, pode-se pensar em uma grande perturbação ou que as peças, mesmo sem apresentarem sinais de lascamento ou uso, tenham sido removidas de seus locais de preparo inicial. Outros núcleos não foram registrados graficamente, como é o caso dos núcleos 6, 11, 16 e 17, uma vez que as lascas que compõem estes núcleos encontramse algumas no setor 1 e o restante nos setores III, IV, V ou VI.

Acredita-se que a dispersão destes núcleos, em que a distância entre suas peças é superior a $4 \mathrm{~m}$, refere-se ao deslocamento antrópico intencional, não podendo ser atribuído a fatores pós-deposicionais. Uma vez que se considerou que a área escavada compõe um único sítio e uma única habitação, sugere-se que as peças deslocadas foram retrabalhadas dentro de um mesmo espaço doméstico, caso contrário seria impossível a colagem de peças entre os setores 1 e III / IV / V / VI.

Neste caso, pode-se citar Leroi-Gourhan e Brézillon (1966, p. 340) sobre a dispersão de núcleos sobre fogueiras em espaços distintos:

Enfin, le nucleus 21.106 partage sés produits entre le trois foyers. Ces faits importants pour établir l'existence d'une zone de circulation commune aux trois cellules et, du point de vue sociologique, pour supposer l'absence de restrictions dans l'emploi de la matière première entre les membres de la communauté. ${ }^{6}$

Desta maneira, e conforme será apresentado no item 4.6 (testemunhos negativos), a dispersão dos testemunhos sugere que os cinco setores escavados são uma única habitação, na qual a matéria-prima e as peças trabalhadas foram compartilhadas pelas três unidades domésticas. Ao mesmo tempo, se considerada a debitagem e lascamento como um critério para a determinação da intensidade de atividade econômica (produção de implementos/artefatos líticos), o setor 1 possui menor atividade que os setores III a VI, uma

\footnotetext{
6 "Enfim, o núcleo C 21.106 compartilha seus produtos entre os três fogões. Estes fatos são importantes para estabelecer a existência de uma zona de circulação comum às três células e, do ponto de vista sociológico, para supor a ausência de restrições no emprego da matéria-prima entre os membros da comunidade."
} 
vez que, tanto a quantidade de núcleos como de lascas produzidas é maior na segunda concentração. Como afirmam LeroiGourhan e Brézzilon (1966, p. 341):

L'expression du movement general des nucleus et des produits conduit à préciser quelques points. On constate que si le trois foyers sont fonctionnellement identique sous l'angle du débitage du silex, le foyer I n'a connu qu'une faible activité l'essentiel du travail s'est partagé entre le foyers II et III. 7

Sendo assim, e como será apresentado logo abaixo, acredita-se que esses testemunhos indicam que a atividade social (ou econômica) acontecia com maior intensidade nos setores III a VI dessa escavação, seja pelo número de núcleos trabalhados seja pela quantidade de material produzido.

\subsubsection{A cerâmica}

A cerâmica será tratada também sob dois aspectos: a distribuição do total de fragmentos escavados em um primeiro momento, e a distribuição das bordas segundo o tratamento de superfície e função em um segundo momento. Para o acompanhamento dos setores no ambiente do sítio e a espacialidade de um em relação ao outro, ver Anexo 1 (figuras 4 e 5$)$.

A distribuição dos fragmentos cerâmicos em todos os setores demonstra a dispersão destes ao longo de toda a área escavada (as grandes áreas em branco nos setores V e VI devem-se à manutenção de blocos testemunho que não foram escavados pelas equipes) (ver Anexo 2: Foto 15; e Anexo 4: Gráficos 26 e 28).

Percebeutse que ações pós-deposicionais deslocaram diversas peças cerâmicas, uma vez que diversos fragmentos foram possíveis de serem "colados", conforme pode ser visto no Anexo 4 (Gráficos 47 e 48). No entanto, se no Setor 1 a proximidade das peças reflete uma pequena perturbação ou movimentação de peças, nos Setores III a VI os fragmentos colados que pertencem a mesma peça foram deslocados, em certos casos, a alguns metros uns dos outros. Neste trabalho não serão aprofundadas as causas destas perturbações (para alguns exemplos registrados neste sítio, ver MILDER, 2000).

Ainda assim, puderam-se visualizar concentrações que delimitam a dispersão dos fragmentos e possíveis "áreas de circulação", nos quais a sobreposição das manchas de dispersão de carvão das fogueiras, observadas nas fotos, sobrepõem-se à dispersão dos

\footnotetext{
7 “A expressão do movimento geral dos núcleos e dos produtos conduzem a precisar alguns pontos. Constatase que, se os três fogões são funcionalmente idênticos sob o ângulo de debitagem do silex, o fogão I conheceu somente uma fraca atividade, e o essencial do trabalho se repartiu entre os fogões II e III."
} 
testemunhos (ver Anexo 4: Gráficos 27 e 29). Embora a quantidade de fragmentos seja significativa, esta distribuição é resultado da fragmentação das vasilhas sobre as fogueiras e dispersão por ações pós-deposicionais.

A forma proposta para avaliar a funcionalidade das áreas em relação à cerâmica passa diretamente pela funcionalidade das próprias vasilhas, como estabelecido por Brochado e alunos (BROCHADO, MONTICELLI e NEUMAN, 1990; BROCHADO e MONTICELLI, 1994). Assim, a distribuição das vasilhas conforme a função acentuará as áreas nos quais a preparação e o consumo dos alimentos era realizado.

Uma análise funcional a partir do tratamento de superfície coloca em questão uma das propostas desta tese: de que os diferentes acabamentos das vasilhas são utilizados em funções específicas, a saber: o corrugado e suas variações (tipos de corrugado e corrugado-ungulado) estão associados a vasilhas que preparam alimentos sobre o fogo, com função de cozinhar, assar, ferver, fritar e respectivas variações (por exemplo, cozinhar alimentos em que o resultado final é ensopado ou cozido). Nos Gráficos 30 e 32 do Anexo 4, são apresentados as bordas corrugadas e variantes, em áreas coincidentes com as fogueiras ou fogões. Notadamente, o corrugado é utilizado em vasilhas que têm a função de preparação de alimentos:

- No caso das panelas, das 156 bordas, 151 são corrugadas e somente cinco corrugadaunguladas $^{8}$ (ver Anexo 3: Fotos 10 a 14). A distribuição das panelas encontra-se no Anexo 4 (Gráficos 34 e 35);

- Nas tigelas ou caçarolas, do total de 76 bordas, 49 são corrugadas, 18 corrugadasunguladas e apenas 9 unguladas. Destas, a maior parte são muito pequenas ou pequenas ${ }^{9}$ (ver Anexo 3: Fotos 15 a 17). A distribuição das tigelas de cozinhar encontra-se no Anexo 4 (Gráficos 36 e 37);

- A exceção que confirma a regra dá-se nos pratos (20 ao total) que possuem tratamento de superfície corrugado, ficando em aberto seu uso sobre o fogo. A distribuição dos pratos encontra-se no Anexo 4 (Gráficos 41 e 42).

Da mesma forma, percebe-se que as vasilhas decoradas ${ }^{10}$ estão vinculadas às funções de preparação, armazenagem ou de servir os alimentos. As classes de vasilhas, já expostas no

\footnotetext{
8 As bordas corrugadas-unguladas de panelas têm os seguintes diâmetros de boca: 22, 20,15 e $11 \mathrm{~cm}$. Uma delas foi impossível de verificar o diâmetro.

9 Das nove tigelas unguladas, duas possuem $30 \mathrm{~cm}$ de diâmetro, uma tigela com $22 \mathrm{~cm}$, uma com $18 \mathrm{~cm}$, uma com $12 \mathrm{~cm}$, duas com $8 \mathrm{~cm}$ e em duas não foi possível ser reconstituído o diâmetro.

10 Aqui se inclui o ungulado, pois, como exposto acima (capítulo dois), o ungulado aparece geralmente em vasilhas anteriormente alisadas, sendo assim, uma decoração. Ademais, o ungulado é utilizado preferencialmente
} 
capítulo dois, podem ser assim relacionadas: as tigelas de beber, como o próprio nome sugere, são utilizadas para servir bebidas, não sendo levadas ao fogo; da mesma forma, as talhas seriam utilizadas para conservar, guardar ou fermentar líquido. Embora esta afirmação seja impossível sem o aporte etnográfico ou etno-histórico, é certo que não iam ao fogo, ou, caso fossem, não eram utilizadas para a preparação de alimentos. Isto é visível nos fragmentos de vasilhas (principalmente panelas e tigelas) que foram analisadas com restos de alimentos ainda em sua superfície interna. Em termos numéricos, a relação entre as formas e o tratamento de superfície ocorre da seguinte maneira:

- No caso das tigelas de beber, todas são pintadas (101 bordas). A distribuição das tigelas de beber encontra-se no Anexo 4 (Gráficos 39 e 40);

- As tigelas de beber devem ter papel diferenciado em relação à forma; podem ser observados dois conjuntos facilmente distinguíveis: as tigelas de beber com pintura externa (carenadas, com fundo plano, geralmente de borda vertical ou extrovertida) e com pintura interna (de contorno simples, fundo semi-esférico, borda extrovertida e pintura predominantemente vermelha);

- No caso das talhas, embora em número reduzido (4 bordas), todas são pintadas. Ainda assim, os grandes fragmentos de corpo de vasilhas que são pintados possuem as carenas ou ombros habituais, salientando a função de talhas. A distribuição das talhas encontra-se no Anexo 4 (Gráfico 38).

Considerando-se agora a questão estritamente funcional, a distribuição das vasilhas conforme a função e a dimensão que possuem permite algumas hipóteses de trabalho que devem ser levantadas.

Existem três áreas de concentração de vasilhas. Isto pode ser observado nos Gráficos de distribuição de recipientes separados por funcionalidade (ver Anexo 4: Gráficos 34 a 42). Em especial, acredita-se que as categorias funcionais possam ser separadas considerando o conjunto de vasilhas da mesma classe; assim, supõe-se que:

- Vasilhas de dimensões diferentes (mas mesma função) podem pertencer a um mesmo "conjunto", ou tralha pertencente a um grupo doméstico, no qual cada recipiente é adequado a uma função específica; ${ }^{11}$

\footnotetext{
em vasilhas de dimensões pequenas, ou associados a outros tratamentos de superfície.

${ }_{11}$ La Salvia e Brochado (1989, p. 123) colocam a questão da seguinte forma: "Nenhuma cultura conhecida possui, ao mesmo tempo, um número muito grande de vasilhas diferentes, uma vez que os usos a que são destinados e pela própria discriminação cultural, devem ser limitados dentre uma infinidade de usos possíveis."
} 
- Vasilhas de categorias diferentes, mas espacialmente próximas entre si, podem pertencer a um mesmo "conjunto", delimitando fisicamente a área dos usuários (do fogo, fogueira ou fogão);

- Agrupamentos de vasilhas de função e dimensão diferentes podem definir grupos de afinidade (ou parentesco), considerando a distribuição dos conjuntos.

Esta proposta é apresentada em virtude de ser possível visualizar, através da dispersão das bordas, algumas constantes na distribuição dos artefatos, mesmo considerando os efeitos pós-deposicionais que atuaram no sítio. Estas constantes são as concentrações dos fragmentos de bordas, seja considerado a função ou o diâmetro de boca das vasilhas, somada à concentração dos outros testemunhos disponíveis.

Desta forma, associam-se os seguintes fatores:

- A hipotética delimitação de áreas de circulação, considerando a distribuição geral da totalidade dos artefatos (no Anexo 4, comparar os Gráficos 3 e 5 ao 27 e 29);

- A concentração de vasilhas de função e dimensão diferentes em locais sobrepostos, conforme Gráficos 34, 35, 37 e 40 no Anexo 4;

- Nas áreas delimitadas nos Gráficos 37 e 40 (Anexo 4) e no setor 1 (Gráficos 34, 36 e 39, Anexo 4), é possível observar que os agrupamentos concentram fragmentos de bordas com todas as funções existentes (como panelas, tigelas, pratos etc.), bem como as dimensões arbitrariamente separadas (cada área possui todas as funções nas dimensões pequeno, médio e grande - ou muito grande - quando é o caso).

Desta forma, propõe-se que, face aos conjuntos de elementos elencados até aqui, seja possível propor uma residência composta por três famílias nucleares, com números aproximados entre quatro e oito moradores em cada núcleo. Esta "proposta de demografia" é colocada com base nas dimensões das vasilhas (número de vasilhames pequenos, médios e grandes) e no número de exemplares de cada tipo (número de bordas de tigelas, pratos e panelas). Reitera-se que esta proposta refere-se ao uso do espaço doméstico, estritamente dentro da habitação, pois a área escavada fora do NSA não permite a definição de áreas de atividade fora da moradia.

Isto pode ser confirmado pela distribuição das "manchas escuras", ou NSA, que estão sobrepostas às áreas de concentração de material. Ao mesmo tempo, a observação da quantidade de bordas e dimensões das vasilhas reconstituídas permite sugerir uma hipótese demográfica, a partir da seguinte proposta de interpretação, cruzando a categoria das vasilhas, suas dimensões e localização no setor:

Em relação ao setor 1: 
1) As panelas dividem-se em 7 pequenas, 26 médias, 4 grandes e 2 muito grandes (Anexo 4: Gráfico 34). Destas 39 panelas, o predomínio das vasilhas médias pode sugerir uma família nuclear com, pelo menos, 4 e no máximo 8 indivíduos;

2) No caso das tigelas de comer, o número reduzido de bordas (11) pode auxiliar a delimitar o número de indivíduos: são 2 pequenas, 4 médias, 4 grandes e 1 muito grande (Anexo 4: Gráfico 36). Se, hipoteticamente, se pensar em refeições individuais e comunais, justifica-se propor uma família pequena com o número de 4 a 6 pessoas;

3) As 29 bordas de tigelas de beber também sugerem, através do diâmetro de boca, um predomínio de tigelas médias (18 bordas, Anexo 4: Gráfico 39), o que reforçaria a idéia de apenas uma família nuclear. Embora seja um número expressivo, o grande número de bordas de tigelas de beber, em comparação com as outras categorias, sugere um grande ou seguido consumo de bebidas, por um lado, ou um grande conjunto de tigelas presentes na habitação, fosse utilizado ou não (o conjunto de tigelas de beber é assim representado: 1 tigela pequena, 18 médias e 3 grandes);

4) Os pratos existentes no setor 1 são apenas cinco, sendo as dimensões destes significativos para esta interpretação: um prato possui $12 \mathrm{~cm}$ de diâmetro de boca, outro 16 $\mathrm{cm}$, dois pratos possuíam $32 \mathrm{~cm}$ de diâmetros de boca e um exemplar não pôde ser inferido pelas dimensões do fragmento. Assim sendo, segundo a classificação, há dois pratos pequenos e dois grandes (ver Anexo 4: Gráfico 41). Neste sentido, talvez o consumo em pratos fosse reduzido, ou ainda os alimentos ensopados fossem consumidos em tigelas de beber, o que poderia justificar o elevado número de uma categoria em detrimento da outra;

5) Não há fragmentos de bordas de talhas no setor 1, o que poderia ser explicado pela concentração de bordas de talhas na fogueira dos setores III e V, como será visto adiante.

Como os setores III a VI foram escavados em conjunto, as colocações sobre a distribuição dos artefatos contemplam os quatro setores como uma unidade de escavação. Assim, ver-se-á a totalidade das vasilhas para uma hipótese interpretativa do uso deste espaço:

1) As panelas dos setores III a VI encontram-se distribuídas em duas concentrações pouco claras (ver Anexo 4: Gráfico 35), embora se saiba dos processos pós-deposicionais que agiram no sítio (MILDER, 2000). Porém, se as concentrações baseadas em outros elementos já apresentados forem separadas, como os testemunhos brutos e modificados, pode-se supor que existam duas áreas de maior concentrações: uma entre os setores III e V, nas coordenadas do eixo X (entre 5,00 e 7,00 metros) e outra concentração na intersecção dos setores IV e VI, nas coordenadas do eixo $\mathrm{X}$ (entre zero e 1,00 metro). Na concentração dos setores III e V (à esquerda no Gráfico 35) há 9 bordas de panelas pequenas, 30 médias, 11 grandes e 01 muito 
grande; na concentração dos setores IV e VI (à direita do Gráfico 35), tem-se 5 bordas de panelas pequenas, 15 médias, 5 grandes e nenhuma muito grande. Numericamente, o número de bordas da concentração entre os setores IV e VI (à direita do Gráfico 35, Anexo 4) aproxima-se das bordas de panelas do setor 1, como pode ser visto mo Gráfico 5.

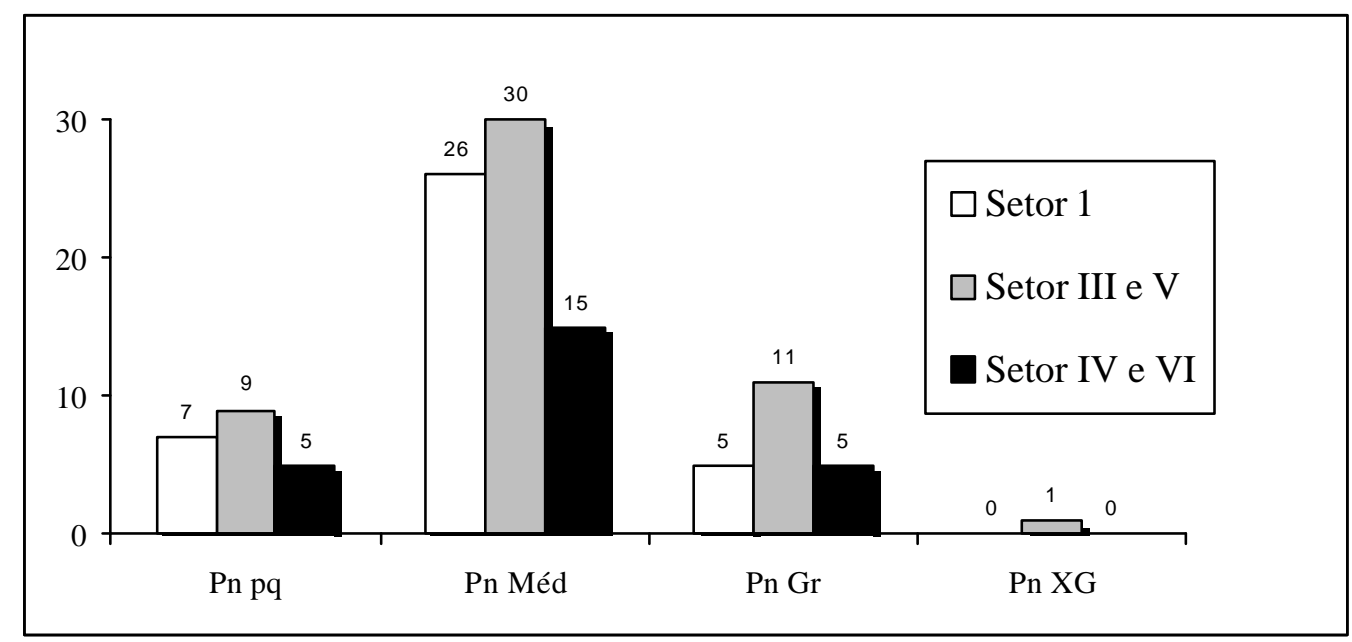

Gráfico 5 - Comparação entre as quantidades de bordas de panelas nas três concentrações.

A distribuição destes fragmentos de bordas leva a crer que a concentração dos setores III e $\mathrm{V}$ possuem praticamente o dobro de fragmentos de borda de panelas da dos setores IV e VI, o que poderia sugerir outras duas famílias nucleares, com número de pessoas distintos. Esta hipótese será reforçada na análise das outras categorias de vasilhas, como será visto a seguir.

2) As tigelas de comer apresentam distribuição semelhante, como observado nas áreas assinaladas no Gráfico 37 (Anexo 4). A concentração entre os setores III e V apresenta uma tigela muito pequena, sete pequenas, onze médias e seis grandes, ao passo que a concentração entre os setores IV e VI apresenta uma tigela muito pequena, três pequenas, cinco médias e duas grandes. É interessante observar que, quantitativamente, o número de fragmentos da concentração dos setores IV e VI é praticamente a metade da concentração dos setores III e V, ao mesmo tempo em que semelhante ao setor 1 (Gráfico 6). 


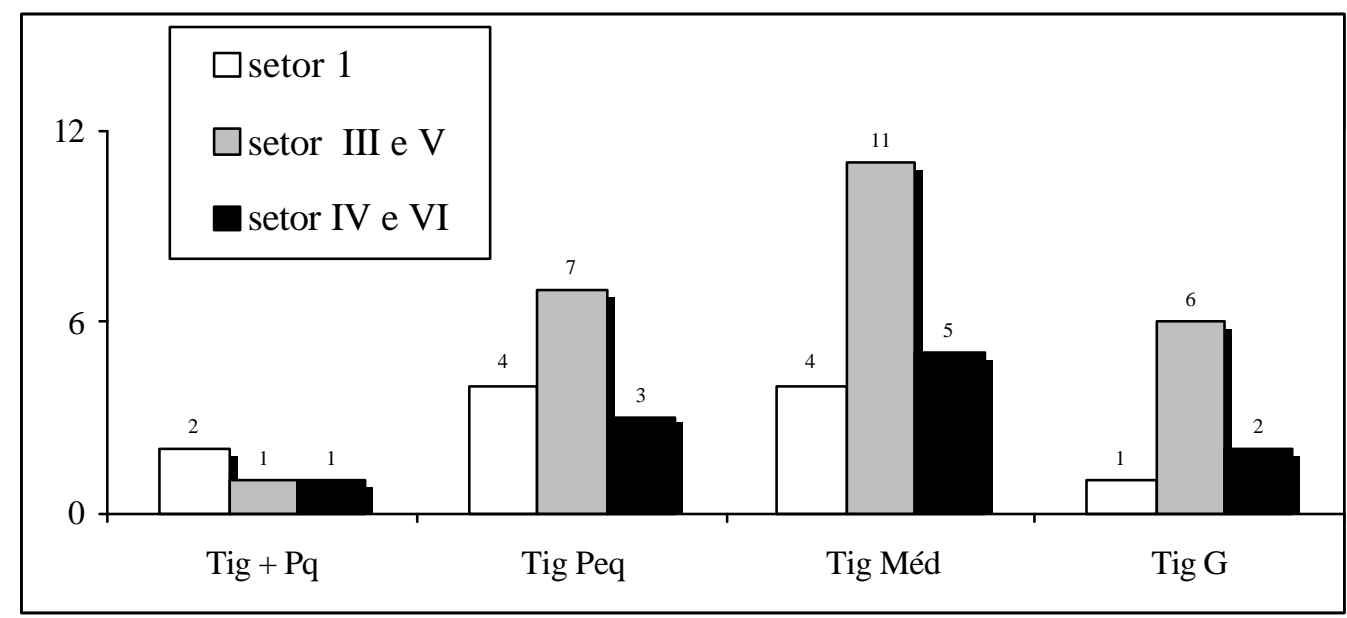

Gráfico 6 - Comparação entre as quantidades de bordas de tigelas de comer nas três concentrações.

Seguindo a mesma linha de raciocínio anterior, ter-se-á, hipoteticamente, duas famílias nucleares nestes setores, uma maior que a outra, e, se houver proporcionalidade entre as vasilhas e seus usuários, poder-se-ia pensar que uma possui o dobro de indivíduos que outra. No mesmo pensamento, o número de ocupantes do espaço habitacional do setor 1 seria numericamente semelhante aos ocupantes da área entre os setores IV e VI, mas praticamente com a metade das pessoas que utilizavam as vasilhas dos setores III e V. Mais uma vez ressalta-se que esta linha de raciocínio só é possível se os moradores utilizassem este espaço como centro de suas atividades diárias, caso contrário estas estimativas não possuem qualquer valor interpretativo.

3) No caso das tigelas de beber (Anexo 4: Gráfico 40), a proporcionalidade nas concentrações se mantém, de forma que, na concentração dos setores III e IV (à esquerda do Gráfico 40, Anexo 4), o número de bordas de tigelas de beber são os seguintes: oito pequenas, dezesseis médias, sete grandes e duas muito grandes. Na concentração dos setores IV e VI (à direita do Gráfico 40, Anexo 4) o número de bordas de tigelas de beber é praticamente a metade: são três pequenas, oito médias, uma grande e duas muito grandes. Na comparação com as bordas das tigelas de beber do setor 1 (Gráfico 7), a proporcionalidade se mantém em parte, uma vez que são três pequenas, dezoito médias e três grandes. 


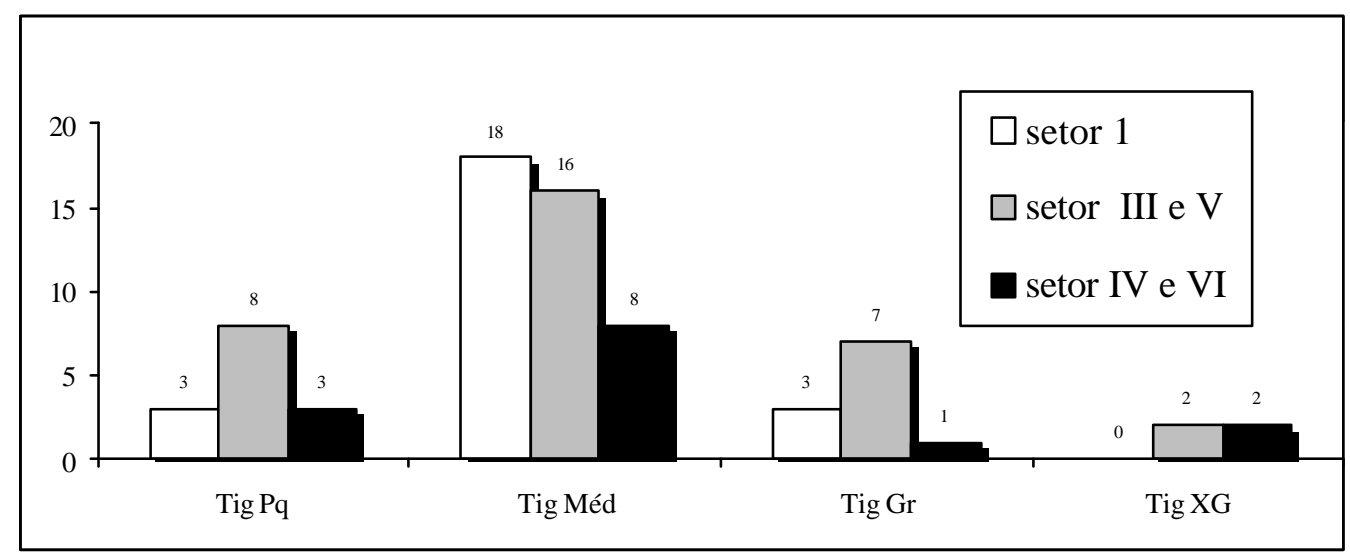

Gráfico 7 - Comparação entre as quantidades de bordas de tigelas de beber nas três concentrações.

Não se sabe o que poderia levar à disparidade das tigelas médias entre o setor 1 e os outros setores. No entanto, as possibilidades de uso diferenciado de espaço ou mesmo de grupos distintos (categorias de idade? separação por gênero?) permanecem em aberto até um estudo mais aprofundado do material.

4) Os pratos apresentam uma distribuição diferenciada (ver Anexo 4: Gráfico 42), embora tenham uma lógica interna: as bordas da concentração dos setores III e V (à esquerda no Gráfico) apresenta uma pequena, seis médias e nenhuma grande. Em oposição, a concentração dos setores IV e VI apresenta duas bordas pequenas, duas médias e três grandes. Se, por um lado, esta distribuição parece contraditória, na comparação com o setor 1 (onde se encontram duas bordas grandes e duas pequenas, ver Gráfico 8) parece que, no que concerne aos pratos, quanto menor a família menor é o número de exemplares de vasilhas médios, o que pode indicar que ou eram pouco utilizados, ou, funcionalmente, as tigelas de fundo aplanado pudessem tomar o lugar dos pratos para servir alimentos.

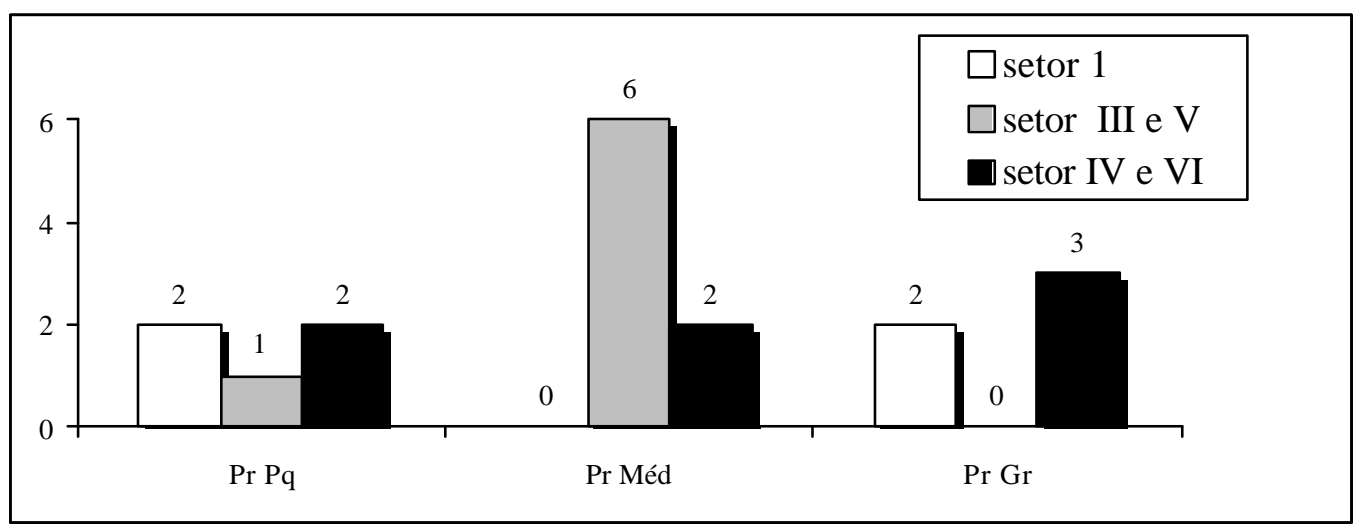

Gráfico 8 - Comparação entre as quantidades de bordas de pratos nas três concentrações. 
Ainda nesta linha de pensamento, talvez as refeições individuais tivessem menor importância que as coletivas, haja vista que em um universo de dezoito pratos, oito são médios e cinco grandes, lembrando que médios são os pratos com diâmetro de boca entre 18 e $24 \mathrm{~cm}$ de diâmetro, enquanto os grandes apresentam de 26 a $40 \mathrm{~cm}$ de diâmetro de boca.

5) A dispersão dos fragmentos de bordas das talhas (Anexo 4: Gráfico 38) demonstra que a área de concentração entre os setores III e V era, no momento do abandono do sítio, o local onde eram guardadas ou utilizadas as vasilhas existentes. O número de fragmentos que pertenceriam a estas talhas não foi contabilizado: primeiro, porque se partiu do princípio que esta categoria de vasilhas, por suas dimensões, produzem muitos fragmentos de corpo, lembrando que, nas coleções de vasilhas inteiras, as talhas geralmente têm sua superfície abaixo da cintura somente alisada, enquanto a parte superior ao diâmetro máximo é pintada. Segundo, porque a concentração dos fragmentos pintados, tanto de bordas como de corpos de vasilhas, encontra-se no entorno das áreas de combustão assinaladas pela dispersão dos testemunhos já apresentados.

Ainda assim, é interessante observar as dimensões dos diâmetros de boca registrados: as talhas com diâmetro de 38 e $48 \mathrm{~cm}$ estão próximas à concentração dos setores III e V, ao passo que a borda de $24 \mathrm{~cm}$ de diâmetro de boca encontra-se na área de concentração dos setores IV e VI. Considerando que, conforme proposto acima, haveria três famílias nucleares ocupando este espaço habitacional, a distribuição de vasilhas cerâmicas permite supor que, além da demografia aproximada de cada família nuclear, pode-se sugerir a importância social que cada uma delas ocupa nesta habitação, caso se parta do princípio de que as vasilhas pintadas, tais como as tigelas de beber e as talhas, deveriam ser utilizadas em ocasiões específicas.

Outra hipótese, descartando o uso discriminado das talhas para ocasiões específicas, é supor que, pela análise da distribuição espacial dos núcleos líticos, somado ao número de bordas de panelas, tigelas de beber e talhas, pode-se observar que a fogueira dos setores III e $\mathrm{V}$ é, em termos de volume de material e quantificação de peças, bastante maior que a fogueira localizada nos setores IV e VI, ou mesmo o setor 1. Isto posto, ou o local desta fogueira era utilizada por um número maior de pessoas, ou deveria ter sido utilizada em ocasiões nas quais havia um número maior de pessoas. Nas duas hipóteses, a fogueira localizada no setor IIII e $\mathrm{V}$ apresenta maior relevância do ponto de vista social, em virtude de sua extensão e testemunhos presentes. 


\subsection{Testemunhos fugazes}

A delimitação da área escavada deveurse, em grande parte, à existência dos testemunhos fugazes tais como a diferença da coloração do solo em virtude da atividade humana e fragmentos de carvão. Neste sentido, as "manchas pretas" que balizaram a pesquisa arqueológica Guarani poucas vezes foi tomada como artefato no sul do Brasil, ao contrário dos trabalhos realizados por Pallestrini (1968/69, 1969,1972/73, 1975) no Paranapanema paulista. Em nosso caso, os núcleos de solo antropogênico (NSA) da área de descarte e da habitação, bem como a dispersão das camadas de terra queimada nas fogueiras, permitiu não somente a delimitação da área a ser escavada como a inferência das áreas de fogos, fogueiras e fogões dentro da habitação.

Embora, neste caso, os testemunhos sejam passíveis apenas de registro Gráfico, as análises de solo realizadas no capítulo dois confirmam que os NSA são resultado da atividade humana, mas não pode ser atribuída diretamente a habitação. Neste sentido, outras escavações amplas deverão determinar o uso específico de áreas externas a habitação, como anexos de preparação e processamento de alimentos como sugerido por Noelli (1993).

No caso dos fragmentos de carvão, encontram-se pequenos resíduos de queima, que foram impossíveis de coleta; porém, registrou-se sua localização espacial para ampliar a análise de estruturação de espaço, partindo do princípio de que os carvões delimitam ou se inserem dentro das áreas de combustão, sejam elas fogueiras, fogos ou fogões, como colocado acima.

No setor 1, a distribuição dos carvões acompanha as áreas de combustão e preparação de alimentos e confecção de artefatos (ver Anexo 4: Gráfico 43). De fato, sobrepondo-se os Gráficos de concentração de cerâmica, lítico ou carvão, pode-se inferir que se tratam de duas fogueiras, delimitadas por "vazios" que serão interpretados mais tarde.

Nos setores III a VI, no entanto, o registro de carvões parece ter sofrido perturbações, haja vista que, no que concerne aos outros testemunhos, não há coincidência entre as manchas de terra enegrecida (que se sobrepõem à dispersão de cerâmica, núcleos líticos e 'vazios') e os fragmentos de carvão registrados. Talvez pelas dimensões e pesos ínfimos, alguns destes testemunhos tenham se dispersado por fatores pós-deposicionais, até agora desconhecidos (Anexo 4: Gráfico 44). No entanto, percebe-se que esta dispersão atuou sobre os setores III a VI com maior intensidade, pois se percebe que outros testemunhos, como os núcleos líticos (Anexo 4: Gráficos 19, 20, 21), a cerâmica (Anexo 4: Gráfico 33), e as peças coladas (Anexo 4: Gráficos 47 e 48) referendam uma ação diferenciada nesses setores. 
As amostras de carvão coletadas em todos os setores foram selecionadas para possibilitar a realização de algumas datações de carbono nos laboratórios Beta Analytic (Miami, EUA) e Laboratorio de Tritio y Radiocarbono - LATYR (La Plata, Argentina), conforme apresentado no capítulo anterior.

\subsection{Testemunhos discretos}

A distribuição dos testemunhos discretos segue o padrão de dispersão dos testemunhos manufaturados. Os resíduos de lascamento estão associados às áreas de fogueiras nos quais os blocos de calcedônia foram aquecidos/partidos e preparados para lascar. Embora seja possível visualizar a dispersão das peças de alguns núcleos, não se pode atribuir este fato ao lascamento em diversos locais, haja vista a não utilização destes blocos após a quebra. Por outro lado, a dispersão destes artefatos sugere a forma como o sítio foi perturbado após seu abandono, o que enriquece a discussão a respeito dos fatores pós-deposicionais em sítios que não estão sujeitos a ação antrópica atual.

No caso dos pequenos blocos de hematita localizados no sítio, sua distribuição pode ser observada no Anexo 4 (Gráficos 45 e 46). A hematita está próxima à fogueira em todos os setores, o que sugere que as atividades de processamento da hematita e transformação do mineral em pigmento ocorriam em um espaço contíguo às áreas de combustão. Da mesma forma que os afiadores em canaleta, os pequenos blocos de hematita encontram-se no entorno das fogueiras, o que permite supor que, se por um lado não havia necessidade do fogo para manipular este pigmento, o uso do local refere-se a escolha preferencial para a realização de atividades cotidianas.

Salienta-se ainda que estes pequenos blocos se decompõem com muita facilidade, o que leva a supor que parte deles desapareceram em contato com o solo, seja pela dimensão reduzida ou pela fragilidade do testemunho. Ao mesmo tempo, observa-se que a hematita acompanha o limite geral da dispersão dos outros artefatos, o que novamente sugere a delimitação de espaços livres, como se verá adiante.

\subsection{Testemunhos negativos}

Os testemunhos negativos, conforme abordado no capítulo dois, são evidências observáveis durante a escavação, mas que o próprio processo de decapagem elimina. Citam- 
se, como testemunhos desta ordem, os negativos produzidos pela decomposição dos esteios e os "vazios" perceptíveis que delimitam, em nosso caso, as áreas domésticas. A respeito dos "vazios", Leroi-Gourhan e Brézillon (1966, p.370) apontam como sua demarcação é importante para a interpretação do uso destes espaços:

Les espaces vides VII-VIII-IX posent une série de problèmes d'interprétation. Ce sont des surfaces sur lesquelles l'ocre fait défaut ou n'empiète que partiellement et où les débris osseux ou lithique sont rares et petits. Il est très probable que ces surfaces étaient normalement recouvertes et qu'elles jouaient le rôle d'espace de couchage. ${ }^{12}$

Não se pode inferir se os espaços vazios em torno das fogueias são, como propõem os autores citados, áreas de dormir ou de descanso. No entanto, a ausência de testemunhos reforça a idéia de que estes locais servem de passagem entre as fogueiras. Uma vez que alguns testemunhos (como os núcleos líticos) apresentam sua dispersão ao longo das concentrações de vasilhas cerâmicas, pode-se inferir que, embora de dimensões reduzidas, trata-se de uma única habitação, com, provavelmente, três famílias nucleares, cada uma ao redor de uma área de combustão.

Essa hipótese encontra sustentação na localização dos dois negativos de esteios. No caso do negativo de esteio escavado no setor 1 (Anexo 2: Foto 14), a alteração no solo possuía aproximadamente $10 \mathrm{~cm}$ de diâmetro e foram escavados $17 \mathrm{~cm}$ de profundidade (para localização do negativo de esteio, ver Anexo 4, Gráfico 26). Considerando que se trata de uma evidência negativa e do extremo do esteio, pode-se imaginar que tanto a largura quanto o comprimento enterrado fossem bem maiores. Observando-se o Anexo 4 (Gráfico 26), vê-se que a localização do esteio permite uma área de circulação em seu redor e próximo ao fogo (Anexo 4: Gráficos 3 e 5).

Desta forma, a proposta de "área de circulação" sugerida diz respeito à delimitação da área de dispersão dos testemunhos (totalidade dos artefatos líticos, cerâmicos e concentração de carvões) que, somada à localização do esteio, permite inferir que as áreas vazias em torno das fogueiras sejam o espaço doméstico pelo qual a passagem deveria ocorrer ou servir de dormitório.

O mesmo ocorre nos setores III a VI, onde a localização de um negativo de esteio ocorreu no limite dos setores IV e VI (Anexo 4: Gráfico 28). A distância entre os negativos de

\footnotetext{
12 "Os espaços vazios VII-VIII-IX possuem uma série de problemas de interpretação. Estes são as superfícies sobre os quais o ocre tem falhas ou somente aparecem parcialmente e onde os fragmentos de ossos ou lítico são raros ou pequenos. É muito provável que estas superfícies fossem normalmente recobertas e que elas desempenhavam um papel de espaço de descanso".
} 
esteio localizados é de aproximadamente $8 \mathrm{~m}$. Como apresentado no capítulo primeiro, as "manchas escuras", registradas por Brochado durante as pesquisas patrocinadas pelo PRONAPA, mediam entre 10 e 30 m de diâmetro (fase Guaratã, no rio Jacuí). Neste caso, é muito provável que a habitação amplia-se muito além da área escavada, e os esteios registrados são estruturas intermediárias, quer dizer, referem-se ao espaço interno e não ao limite da habitação. ${ }^{13}$

Neste caso, a distância entre estes esteios refere-se a uma habitação de dimensões médias, com aproximadamente $120 \mathrm{~m}^{2}$ (considerando as dimensões colocadas por BROCHADO, 1971, ver capítulo 1), ou seja, com um comprimento de, pelo menos, $16 \mathrm{~m} \mathrm{e}$, aproximadamente, $8 \mathrm{~m}$ de largura, considerando a dispersão dos testemunhos.

Outra proposta de aproximação demográfica para os sítios do médio e alto rio Jacuí encontra-se em Klamt (1996b, p. 8), que considera a estimativa aproximativa, pois "se pode fazer somente uma 'aproximação' do número de habitantes de um dado sítio arqueológico e não estipular seu número exato", partindo do princípio que cada "mancha preta" refere-se a uma habitação.

O autor aplica as fórmulas de aproximação demográfica de Cook (1972, apud KLAMT, 1996b) e Casselberry (1974, apud KLAMT, 1996b), pois, segundo estes autores, o número de habitantes é "igual a 1/6 da área do piso medida em metros quadrados" (para Casselberry). Já Cook conclui que "os primeiros habitantes ocupariam uma área de 13,92 $\mathrm{m}^{2}$ e, para cada adicional se precisaria mais 9,29 $\mathrm{m}^{2 "}$ (KLAMT, 1996b, p.7).

Neste sentido, o autor calcula que, para o vale em questão, seguindo as medidas das "manchas pretas", o número mínimo para cada habitação seria de 8 e, no máximo, 116 habitantes (segundo a fórmula de Casselberry) ou o mínimo de 10 e máximo de 80 pessoas por habitação (segundo a fórmula de Cook, em KLAMT, 1996b).

Se forem consideradas ambas as fórmulas e a medida de $120 \mathrm{~m}^{2}$ para esta habitação, conforme a área escavada, ter-se-ia, segundo Casselberry (1974 apud KLAMT, 1996b), 20 habitantes e, segundo Cook (1972 apud KLAMT, 1996b), entre 17 e 18 habitantes. Desta forma, e considerando somente o espaço escavado como uma "mancha preta", infere-se que o número de habitantes desta residência poderia oscilar entre dezessete e vinte pessoas, número este coerente com a proposta apresentada a partir dos outros testemunhos acima arrolados.

\footnotetext{
13 Se for considerada como área de habitação o local de dispersão dos testemunhos e o núcleo de solo antropogênico, deve-se contar as áreas dos setores 1, III, IV, V e VI, incluindo as trincheiras que permitiram o reconhecimento da ocupação (ver Anexo 1, desenhos 3, 4 e 5)
} 
Sendo assim, acredita-se que a distribuição dos diversos testemunhos permite inferir não somente a espacialidade de cada um dos elementos que compõem cada categoria de testemunho, mas, principalmente, sugerir, com alguma segurança, a respeito da demografia, uso do espaço doméstico, local de confecção e distribuição dos artefatos, além da importância social dos moradores desta habitação.

Esta contribuição é no sentido de que, com o controle rígido da escavação e do registro arqueológico (nunca esquecendo que este processo é destrutivo e irreversível), outras análises ainda poderão ser realizadas, como, por exemplo, fatores que atuaram na desestruturação do sítio, causas de abandono, além de uma abordagem etno-histórica, que se pretende realizar em um futuro próximo. 


\section{CONSIDERAÇÕES FINAIS}

Concluir uma tese é delimitar o ponto final de uma pesquisa que, por diversos fatores, não apresenta uma conclusão. Muitas lacunas na análise dos artefatos são complementadas, em parte, por outra tese de doutorado que se encontra em andamento, desenvolvida pelo Professor Sérgio Célio Klamt, doutorando em Arqueologia pela Pontifícia Universidade Católica do Rio Grande do Sul (PUCRS). Análise de recursos disponíveis no ambiente, solos de cultivo em áreas próximas ao sítio RS-JC-57, descrição dos remanescentes de fauna escavadas, relação com outros sítios do vale do rio Jacuí, entre outros elementos, são assuntos tratados por este colega.

Aqui, pretendeu-se apresentar os resultados obtidos com este trabalho e a contribuição que se pretendeu oferecer à pesquisa de sítios arqueológicos Guaranis a partir deste estudo de caso. Mesmo que o sítio já tenha sido pesquisado anteriormente e o vale do rio Jacuí seja um dos mais conhecidos arqueologicamente no Estado do Rio Grande do Sul, alguns resultados podem ser arrolados, bem como sugerir diversos caminhos abertos para novas pesquisas. As considerações serão apresentadas por capítulos, para que, logo após, seja realizado um grande apanhado sobre este estudo.

No primeiro capítulo, a pretensão foi resgatar um pouco da história que envolve a arqueologia Guarani, principalmente no que concerne aos parâmetros que nortearam a pesquisa após a implantação do PRONAPA. No primeiro item, a intenção não foi a de realizar uma apologia ao programa, mas, ao contrário, mostrar a grande quantidade de informações disponíveis nos volumes publicados, que, desde o princípio, aponta para a diversidade de configurações de sítios arqueológicos Guaranis no Estado do Rio Grande do Sul. Neste sentido, é fundamental que se perceba que os Guaranis, embora compartilhem um corpus mitológico e cultural semelhante, realizam uma relação dialética de transformação e adaptação ${ }^{1}$ ao ambiente no qual se inserem.

Disto resulta que não há uma única unidade fitogeográfica exclusiva para o assentamento Guarani, delimitado estritamente em certos compartimentos geográficos (como vales ou altitudes máximas de 400 metros s.n.m.), mas inserção em todos locais onde sua

\footnotetext{
1 “'A adaptação, por sua vez, é encarada como algo que vem 'de dentro' das culturas. Os grupos humanos 'se adaptam', e nunca 'são adaptados'. A cultura por sua vez só pode ser explicada por processos únicos a si mesma, e nunca por princípios e mecanismos atuantes no planeta como um todo" (DUNNELL, 1980, p. 48 apud ARAÚJO, 2001, p .67).
} 
expansão pode ser notada, até a chegada do europeu. Isto pode ser mais bem observado em um mapa de distribuição de sítios na tese de Brochado (1984), no qual se constatam sítios no planalto, sobre sambaquis, ou em altitudes próximas a mil metros, além de regiões de mangue, de cerrado ou em banhados, muito distantes do que foi considerado 'horticultores de floresta tropical'.2

Neste sentido, o resgate da importância do PRONAPA tem dois sentidos: um mea culpa, uma vez que, como outros colegas, acreditava-se que a instalação do Programa fora um retrocesso na metodologia de pesquisa em andamento, além de ser um inibidor daqueles que pensavam diferente ${ }^{3}$ e, segundo, porque existem muitos elementos que podem contribuir para a pesquisa arqueológica. E, como toda a ciência, evolui sobre as edificações deixadas pelos antecessores.

No segundo item, foi apresentada a ruptura realizada por Brochado no desmembramento da Tradição Tupiguarani em Subtradição Guarani. Ainda hoje não é demasiado explicar o avanço que esta separação representou no final dos anos 1970' (BROCHADO, 1980). Propondo uma abordagem que contemplasse os dados históricos, lingüísticos e etnográficos, Brochado propõe uma visão integrada para as culturas arqueológicas. Mais que isso, atribui etnicidade à cerâmica, propondo a ligação entre a cultura material e a sociedade que a produziu. A terminologia prosseguiu a mesma, uma vez que Brochado (ou qualquer de seus alunos) não propôs uma abordagem diferente dos conceitos de Tradição ou Subtradição, no sentido de filiação cultural através da tecnologia e, mais precisamente, a cerâmica. No entanto, o acréscimo ofertado por Brochado na arqueologia Guarani ainda está por ser quantificado, ${ }^{4}$ embora alguns trabalhos apontem sua contribuição (NOELLI, 1993).

No segundo item questionourse sobre a origem amazônica dos Guaranis que merecerão atenção de pesquisas futuras, principalmente para que os modelos possam ser enriquecidos com dados arqueológicos além dos lingüísticos e históricos. Neste sentido, acredita-se que os conceitos de Tradição e Fase foram úteis em uma etapa classificatória, porém não atendem mais aos atuais questionamentos sobre os antepassados dos Guaranis.

No terceiro item, buscou-se demonstrar que uma vertente passível de ser resgatada na arqueologia Guarani é aquela que busca atribuir etnicidade à cultura material e assentamento

\footnotetext{
2 "Sua economia e sua cultura se encaixavam perfeitamente no que os antropólogos estão acostumados a denominar horticultores da floresta tropical, como existem ainda hoje na Amazônia" (SCHMITZ, 1997, p.296).

${ }^{3}$ Para acompanhar o histórico das críticas realizadas ao programa, ver Soares (1996,1997, 1999, 2000).

${ }^{4}$ NOELLI, Francisco. José Proenza Brochado: vida acadêmica e idéias sobre o passado dos povos Tupi. 2004, não publicado.
} 
ou, dito de outra forma, demonstrar que o avanço da pesquisa em arqueologia poderá rastrear conceitos já trabalhados pela Etnografia e pela História, como as parcialidades, ou grupos étnicos distintos entre si, mas que compartilhariam a língua Guarani. Neste sentido, demonstraram-se como as pesquisas de Brochado também apontaram nesta direção desde a década de 1970, mas que, por razões desconhecidas, não foram desenvolvidas.

Em documentos inéditos, como relatórios de pesquisa, correspondência pessoal e artigos não publicados, foi possível "rastrear" parte da produção e das idéias originais que, propostas por este eminente pesquisador, ainda estão por serem confirmadas. Um exemplo é a tentativa de atribuição de parcialidades eticamente definidas (em contraposição ao êmico) a partir dos conjuntos cerâmicos na época classificados como fases que, conforme proposto, talvez possa ser retomada a partir de outros critérios diferentes da seriação cerâmica.

Outro ponto apresentado neste item é a proposta de Arqueologia Guarani. Considerando as limitações dos conceitos histórico-culturalistas para a definição de qual conjunto de atributos constitui a cultura material Guarani, foi proposta uma análise que fosse o somatório de diversas outras análises, ${ }^{5}$ de forma que seja construído sobre uma definição ampla o suficiente para congregar os distintos regionalismos (parcialidades) e restrita para que possibilite, ao mesmo tempo, diferenciar de outros grupos (não-Guaranis, como Tupinambás e outros). Neste trabalho, não se atribui nenhuma etnicidade ao material escavado por dois motivos: primeiro, porque esta atribuição teria o peso aumentado de dados históricos e etnográficos não utilizados nesta tese; segundo, do ponto de vista da cultura material, ainda não há coleções ou escavações para comparação.

No capítulo dois, apresentaram-se os procedimentos da escavação dos sítios RS-JC-56 e RS-JC-57. Estes dois sítios foram considerados como duas áreas de um mesmo sítio, com funcionalidades distintas. No caso do sítio RS-JC-56, a forma das lentes de núcleo de solo antropogênico (NSA), a localização e deposição das mesmas, o perfil do talude do rio e os testemunhos arrolados indicam que este local foi utilizado como área de descarte do sítio RSJC-57, denominado área de habitação. Propuseram-se duas questões que deverão ser consideradas nas pesquisas sobre sítios Guaranis: o caráter da disposição das evidências e a profundidade do NSA no vale do rio. Esses dois componentes induziram e ainda levam pesquisadores a considerar alguns sítios como destruídos ou realizar sondagens de até $50 \mathrm{~cm}$ como "limite" para a ocupação Guarani.

\footnotetext{
5 Atributos estilísticos e morfológicos da cerâmica, identificação histórica dos grupos, distintos padrões de assentamento, análises físico-química das cerâmicas e solos antropogênicos.
} 
Ainda no capítulo dois, propôs-se a abordagem das evidências segundo a proposta de Leroi-Gourhan e Brézillon (1969 e 1972), adaptadas às condições do Brasil por Pallestrini (1968/69, 1969, 1972, 1975). Esta classificação permitiu uma abordagem mais integrada entre os artefatos, uma vez que a separação segundo a matéria-prima dos objetos não contemplaria os tipos de alterações antrópicas realizadas no espaço da habitação.

Desta forma, esta abordagem contemplou a ocupação do espaço através da análise de objetos não alterados pela ação humana, aqueles que apresentaram alterações não intencionais, os artefatos propriamente ditos, os NSA, as microevidências e as evidências negativas e espaços vazios. Assim, nesta proposta, por um lado, realizaram-se análises pouco usuais para a arqueologia do Rio Grande do Sul; por outro, não se explorou as análises de praxe sobre a cerâmica e lítico, como a descrição das dimensões, peso, pasta etc. Apresentou-se, no entanto, a forma como os habitantes utilizaram, alteraram e modificaram os diferentes recursos minerais e o solo de sua ocupação:

- sob a forma de pedras não utilizadas, carregadas até o sítio mas sem nenhum sinal de utilização;

- na qualidade de suporte ou condutoras de calor, denominadas termóforas;

- na confecção de artefatos de arenito, como os afiadores de canaleta, as lascas de calcedônia, de riolito, ou os fragmentos de lâminas polidas (prováveis lâminas de machado quebradas);

- na quantificação de cerâmica representada através de sua classificação funcional, propondo que, de acordo com o conjunto estudado, pode-se estabelecer ainda uma separação arbitrária de dimensões que auxiliam a criação de hipóteses demográficas;

- nas análises químicas do solo antropogênico, no qual se sugere que estas análises confirmam o caráter antropogênico das "manchas pretas", bem como auxiliam na determinação da funcionalidade dos NSA;

- na análise da distribuição de microlascas e diminutos blocos de hematita, que auxiliaram na determinação do uso dos espaços internos da habitação;

- na análise dos espaços "vazios" e evidências negativas, que, neste caso, possibilitam a sugestão de hipóteses sobre as dimensões da habitação e das áreas de circulação.

No capítulo três, apresentou-se a cronologia absoluta do sítio, discutiram-se as datas já realizadas em sítios Guaranis no Estado e as datas realizadas pela equipe envolvida. Apresentou-se também um conjunto de datações obtidas a partir de fragmentos cerâmicos, sedimentos e carvão, realizadas 20 datas através de Termoluminescência (TL) e uma de radiocarbono $\left(\mathrm{C}_{14}\right)$ sobre o sítio, além de outras sete em sítios próximos ao RS-JC-57. 
Inicialmente, no primeiro item, foi realizado um breve histórico das datações nos sítios Guaranis. Foram apresentadas as datas presentes na tese de doutoramento de Brochado e algumas referentes à ocupação Tupiguarani (da região Sul) presentes em um dactiloscrito depositado na Pontifícia Universidade Católica (PUC-RS), muitas delas não-publicadas, seguidas de um juízo de valor de Betty Meggers. Demonstraram-se, ainda, alguns critérios que nortearam a divulgação (ou invalidação) das datações e o modo como estas foram utilizadas para respaldar o modelo de ocupação tardia das terras baixas do leste da América do Sul. Assim, acredita-se que a discussão sobre a antiguidade da presença Guarani no Brasil meridional passa, sobretudo, pelos modelos e paradigmas adotados, e menos pelas limitações dos métodos e técnicas utilizados.

No segundo item do capítulo três, apresentaram-se as datas realizadas pelo método de termoluminescência (TL) no LACIFID. As datas realizadas em fragmentos de cerâmica e sedimentos apresentaram um recuo considerável na antiguidade da ocupação Guarani no Estado do RS. Outras datações realizadas pelo mesmo método, no mesmo laboratório, demonstraram a confiabilidade nos procedimentos, conforme pode ser observado em datações sobre urnas do período histórico (SOARES e MILDER, 2003). Por outro lado, o conjunto de datas realizado neste sítio é, em vários pontos, incoerente entre si.

No terceiro item, apresentaram-se as datações de TL realizadas pelo Laboratório de Vidros e Datação da Faculdade de Tecnologia de São Paulo (FATEC) que, ainda que utilizando o mesmo método, datou fragmentos de cerâmica com antiguidade entre mil e mil e duzentos anos antes do presente (entre 1000 e 1200 BP). Embora dentro dos paradigmas aceitos para a arqueologia Guarani do sul do Brasil, estas datações são contraditórias com as realizadas pelo laboratório anterior. Sendo assim, realizou-se uma datação por radiocarbono, apresentada no quarto item deste capítulo que, embora com ressalvas sobre a validade dos resultados obtidos em virtude de se tratar de uma datação indireta, ainda é a mais aceita no meio acadêmico. No entanto, o resultado obtido, de 470+ 50 antes do presente, remete a uma ocupação, com 95\% de probabilidade, entre os anos de 1400 e 1490 da Era Cristã. Acredita-se que o conjunto de datas realizadas demonstra claramente duas questões: 1) a problemática de acreditar-se em um único método como possível de determinar a cronologia de ocupação e 2) a necessidade de se realizarem mais de uma ou duas datações para que o resultado seja satisfatório, ao invés de acreditar em um método ou data por presentar resultados aceitáveis dentro dos modelos existentes. 
Ainda no terceiro item do terceiro capítulo apresenta-se a proposta de um período provável de ocupação, em vez de uma única datação, situado entre os séculos III e XIII desta Era, compatível com as outras datações existentes e as datas realizadas no vale do rio Jacuí.

No quarto capítulo, apresentou-se a distribuição dos testemunhos e as inferências e interpretações realizadas a partir dela. Neste sentido, acredita-se que a disposição das evidências, mesmo considerando as perturbações pós-deposicionais, é relevante e significativa para atribuir usos e funções aos espaços analisados. A distribuição dos testemunhos brutos (item 4.1) sugere a área de dispersão das evidências que, mesmo sem utilização, apontam para a delimitação das áreas de circulação e uso do espaço. De fato, mesmo que os blocos e seixos de basalto e arenito não apresentem sinais de utilização, o fato de terem sido levados para dentro da habitação indica alguma utilidade, desconhecida ou imperceptível, que levou os Guaranis a transportarem estes testemunhos.

Os testemunhos modificados (item 4.2), constituídos pelas termóforas, delimitam, ainda que não perfeitamente as áreas em que o fogo estava presente, com suas respectivas atividades, sob a forma de fogos, fogueiras ou fogões. Denominados estruturas de combustão, acredita-se que estas estruturas podem se apresentar de diferentes formas e, conseqüentemente, com distintas funções. Sendo assim (e conforme exposto no item 2.2.2), propõe-se um tratamento diferenciado para estas estruturas, uma vez que é possível observálas em escavações controladas.

Os testemunhos manufaturados (item 4.3) corroboram a idéia de que é possível propor áreas em que ocorria, preferencialmente, a produção e/ou manipulação dos artefatos. Desta forma, observa-se que os habitantes trabalhavam, independente da matéria-prima, junto à fogueira ou encontravam-se próximos a esta, a fim de confeccionar seus utensílios.

A distribuição dos fragmentos cerâmicos compõe um item à parte. Em primeiro lugar, observa-se uma dispersão diferenciada nos setores. Conforme observado a partir dos fragmentos colados, o setor 1 foi alvo de menos perturbações que os setores IV a VI. É possível que esta diferença possa ser atribuída à declividade do piso original, ou a ações pósdeposicionais que deslocaram acentuadamente todos os testemunhos nestes setores.

Em segundo lugar, a análise da distribuição dos fragmentos de borda, com base no cruzamento entre o tratamento de superfície, a funcionalidade e a dimensão do diâmetro de boca reconstituído, permitiu levantar hipóteses sobre a relação entre os conjuntos de vasilhas e a utilização do espaço habitacional. Observou-se que as três áreas de concentração de recipientes cerâmicos apresentaram todas as categorias de vasilhas em todas as dimensões. 
Esta informação, em associação com os testemunhos negativos, permite sugerir o número de habitantes, como será apresentado adiante.

Os testemunhos fugazes (item 4.4) permitiu o registro das estruturas de combustão, bem como uma proposta interpretativa destas estruturas. Neste estudo de caso, acredita-se que é possível uma diferenciação entre fogueiras, fogos e fogões, a partir das evidências presentes, bem como a característica morfológica de cada estrutura, conforme apresentado no item 2.2.2. Também se registrou as alterações provocadas pela combustão e o mapeamento dos fragmentos de carvão, que se distribuem distintamente nos setores escavados. Pôde-se observar que, enquanto no Setor 1 os fragmentos de carvão encontram-se na mesma área ocupada pelos testemunhos modificados, delimitando com certa precisão as estruturas de combustão, nos setores III a VI a dispersão dos carvões evidenciam as perturbações pelo qual passou o sítio.

Os testemunhos discretos (item 4.5) podem ser divididos em dois grupos: as microlascas e os blocos de hematita. As primeiras são resultado da decorticação dos blocos de calcedônia que, pela ação do aquecimento ao fogo, foram partidos. As microlascas são, provavelmente, o resultado involuntário das inúmeras tentativas de lascamento sobre núcleos aquecidos de forma inadequada ou imprópria, uma vez que, além de reconstruir alguns núcleos, observou-se que as lascas e microlascas não foram utilizadas.

Os pequenos blocos de hematita foram recuperados próximos às fogueiras, o que leva a sugerir que o processamento ocorria no entorno das estruturas de combustão. Além disso, registrou-se a existência da hematita mesmo quando esta se encontrava deteriorada a ponto de inviabilizar sua coleta.

Os testemunhos negativos (item 4.6) possibilitaram a consolidação de algumas hipóteses arroladas ao longo desta tese. Em primeiro lugar, sugere-se que alguns espaços vazios, ou seja, sem a presença de artefatos ou alterações do solo, poderiam ter seu uso como área de circulação ou como local de descanso. Ao mesmo tempo, pela análise dos negativos de esteio existentes no sítio, busca-se inferir as dimensões da habitação. Uma vez que foram escavados aproximadamente $120 \mathrm{~m}^{2}$, e considerando o registro de dois negativos de esteio, sugere-se a possível delimitação da área de cada unidade doméstica dentro da habitação. Ao mesmo tempo, sugere-se também o número de habitantes da habitação, considerando os diferentes testemunhos e as fórmulas demográficas apresentadas.

Assim, coloca-se novamente a questão: qual a contribuição desta tese? Acredita-se que vários são os subsídios ofertados, e também outras tantas sugestões. Inicialmente, acredita-se que a trajetória da arqueologia Guarani é bastante conturbada, plena de reveses e surpresas. É 
difícil, em contato com a vasta literatura, tanto histórica como etnográfica, não se envolver com a questão indígena de forma passional. Daí um dos motivos que levaram à realização desta tese desta maneira: buscar apresentar um texto o mais árido possível sem as paixões que a história e a etnografia tão bem proporcionam.

Ao mesmo tempo, havia um problema pessoal: fazer Arqueologia da forma tradicional, no sentido de que a análise dos artefatos produzidos, modificados intencionalmente ou não, iniciasse na escavação e concluísse com a publicação. Dito de outra forma, havia a necessidade de fazer uma análise empírica sobre os objetos, e daí, sobre o que é possível de afirmar (ou não) a respeito deles. Neste sentido, de forma alguma se ne gou a contribuição da analogia histórica e etnográfica na construção de hipóteses plausíveis para a interpretação destas sociedades no passado; esse trabalho será realizado na continuidade deste. Todavia, acredita-se que faltava uma contribuição nos moldes aqui realizados, quer dizer, a busca de possíveis inferências a partir do registro arqueológico.

Foram acrescentadas também algumas sugestões para possíveis pesquisas como: poder-se-ia comparar os resultados aqui obtidos com os obtidos em outras escavações em áreas amplas, bem como ampliar o rol de testemunhos observados e registrados.

Outro ponto importante salientado não diz respeito a conclusão deste trabalho, mas a sua trajetória. Quando foi iniciada a análise deste sítio, havia uma grande quantidade de informações históricas, etnográficas, lingüísticas e alguma experiência de vida entre os Guaranis. Quando se optou por realizar uma análise "dura" dos artefatos e buscar um distanciamento emocional do objeto de estudo, foi proposta a prática de uma arqueologia difícil, pois é sabida a quantidade de empecilhos existentes desde a escavação até a análise dos materiais. Então, a trajetória desta tese mostrou a grande dificuldade de se fazer arqueologia neste País, e porque são tão poucas as grandes escavações com grandes estadas em campo. Por outro lado, estas dificuldades só aumentaram o desejo de permanecer em atividade e, se possível, escavar outros sítios em grandes áreas.

Ao mesmo tempo, devem-se colocar os próximos passos que serão efetuados. As análises de assinaturas químicas em fragmentos cerâmicos mal começaram a dar resultados, o que permitirá, em curto espaço de tempo, avaliar a troca e o comércio de recipientes entre grupos. As análises de solo permitirão, em pouco tempo, afirmar as concentrações em pequena escala, o que viabilizará a definição melhor dos espaços ocupados (com maior evidências de restos de caça ou vegetais e, por extensão, casas fixas, acampamentos de caça ou de roça). 
O material do sítio RS-JC-56/57 foi analisado sob uma abordagem. Análises de cadeia operatória para o lítico, composição de pasta para a cerâmica, bem como muitas outras poderão ser, ainda, desenvolvidas. Por enquanto, deu-se uma pequena contribuição que auxiliará a conhecer uma parte da pré-história dos Guaranis e, quiçá, do Estado do Rio Grande do Sul. 


\section{REFERÊNCIAS BIBLIOGRÁFICAS}

ASSOCIAÇÃO BRASILEIRA DE NORMAS TÉCNICAS. Informação e documentação referências - elaboração: NBR 6023. Rio de Janeiro, 2000, 22 p.

ASSOCIAÇÃO BRASILEIRA DE NORMAS TÉCNICAS. Informação e documentação citações em documentos - apresentação: NBR 10520. Rio de Janeiro, 2002a, 7 p.

ASSOCIAÇÃO BRASILEIRA DE NORMAS TÉCNICAS. Informação e documentação livros e folhetos - apresentação: NBR 6029. Rio de Janeiro, 2002b, 9 p.

AGUILAR, N. (Org.). Mostra do redescobrimento: arqueologia. Fundação Bienal de São Paulo. São Paulo: Associação Brasil 500 Anos Artes Visuais, 2000.

ARAÚJO, A. G. M. Geociências e suas implicações em teoria e métodos arqueológicos. Revista do Museu de Arqueologia e Etnologia, São Paulo, Suplemento 3, p. 35-45, 1999.

ARAÚJO, A. G. M. Teoria e método em arqueologia regional: um estudo de caso no alto Paranapanema, estado de São Paulo. 623f. Tese (Doutorado em Arqueologia Brasileira) FFLCH, Universidade de São Paulo, São Paulo, 2001.

BAHN, P. Tudo que você precisa saber sobre arqueologia para nunca passar vergonha. Adaptação de Bluff Your Way in Archaeology. Rio de Janeiro: Ediouro, 1993.

BINFORD, L. Where do research problems come from? American Antiquity, v. 66, n. 4, p. 669-678, 2001.

BRAIDWOOD, R. Homens pré-históricos. 2. ed., Brasília: UNB, 1988.

BROCHADO, J. P. Pesquisas arqueológicas nos vales do Ijuí e Jacuí. In: Simões, M. (ed.). Programa Nacional de Pesquisas Arqueológicas 3: resultados preliminares do terceiro ano (1967-1968). Museu Paraense Emílio Goeldi, publicações avulsas n. 13, p. 31-62, 1969.

BROCHADO, J. P. Extensão das pesquisas arqueológicas nos vales do Jacuí e Ibicuí-mirim, Rio Grande do Sul. In: Simões, M. (ed.). Programa Nacional de Pesquisas Arqueológicas 4: resultados preliminares do quarto ano (1968-1969). Museu Paraense Emílio Goeldi, publicações avulsas n. 15, p. 11-36, 1971.

BROCHADO, J.P. Migraciones que difundieron la tradición alfarera Tupiguarani. Relaciones, Buenos Aires, tomo VII (Nueva Série), p.7-39, 1973.

BROCHADO, J. P. Pesquisas arqueológicas no escudo cristalino do Rio Grande do Sul (Serra do Sudeste). In: Simões, M. (ed.). Programa Nacional de Pesquisas Arqueológicas 5: resultados preliminares do quinto ano (1969-1970). Museu Paraense Emílio Goeldi, publicações avulsas n. 26, p. 25-52, 1974.

BROCHADO, J.P. 1975 Desarollo de la tradición tupiguarani (A.D. 500-1800). In: SIMPÓSIO NACIONAL DE ESTUDOS MISSIONEIROS, 1., 1975, Anais ...Santa Rosa, 1975. p. 76-154.

BROCHADO, J. P. A tradição cerâmica tupiguarani na América do Sul. Clio, Recife, n. 3, p. 47-60, 1980.

BROCHADO, J. P. An ecological model of the spread of pottery and agriculture into eastern South America. Thesis (PhD) - Urbana-Champaign, University of Ilinois at UrbanaChampaign, 1984. 
BROCHADO, J. P.; MONTICELLI, G.; NEUMANN, E. Analogia etnográfica na reconstrução gráfica das vasilhas guarani arqueológicas. Veritas, Porto Alegre, v. 35, n.140, p. 727-743, dez. 1990.

BROCHADO, J. P.; MONTICELLI, G. Regras práticas na reconstrução gráfica das vasilhas de cerâmica guarani a partir dos fragmentos. Estudos Ibero-Americanos, Porto Alegre, v. XX, n.2, p.107-118, dez. 1994.

CARLE, M. B. Investigação arqueológica em Rio Grande: uma proposta da ocupação guarani pré-histórica no Rio Grande do Sul. 2002. Dissertação (Mestrado em História IberoAmericana) - PUCRS, Porto Alegre.

CHANG, K. Nuevas perspectivas em arqueología. Madrid: Alianza, 1967. En 'El Libro de Bolsillo', 1976, 2. ed. 1990.

CHMYZ, I. Dados arqueológicos do baixo rio Paranapanema e do alto Paraná. In: Simões, M. (ed.). Programa Nacional de Pesquisas Arqueológicas 5: resultados preliminares do quinto ano (1969-1970). Museu Paraense Emílio Goeldi, publicações avulsas, n. 26, p. 67-90, 1974.

CHMYZ, I. Sétimo relatório das pesquisas realizadas na área de Itaipu (1981-1983): projeto arqueológico Itaipu, Convênio Itaipu-IPHAN, Curitiba, 1983.

COSTA, C. O.; CARLE, M.; HILBERT, K. Análise do material cerâmico guarani de Povo Novo, Rio Grande, RS. In: CONGRESSO DA SOCIEDADE DE ARQUEOLOGIA BRASILEIRA, 9., 1997, Anais... Rio de Janeiro, 2000.

DIAS, A. S. Repensando a tradição humbú a partir de um estudo de caso. Dissertação (Mestrado em História Ibero-Americana) - PUCRS, Porto Alegre, 1994.

EMBRAPA. Centro Nacional de Pesquisa de Solos. Manual de métodos e análises de solo. 2. ed. Rio de Janeiro. 1997. 212 p.

FAJARDO, F. 2001 Aspectos da ocupação pré-colonial platina: Cabeceira do Raimundo. Dissertação (Mestrado em Integração Latino-Americana) - Universidade Federal de Santa Maria, Santa Maria, 2001.

FAUSTO, C. Fragmentos de história e cultura tupinambá: da etnologia como instrumento crítico do conhecimento etno-histórico. In: CUNHA, M.C. Índios do Brasil. São Paulo: SMC/FAPESP/Cia. das Letras, 1992.

FORD, J. Método cuantitativo para establecer cronologías culturales. Manuales Técnicos III, Washington, D.C.: Union Panamericana, 1962.

FUNARI, P. P. A. Lingüística e Arqueologia. DELTA - Revista de Estudos de Lingüística Teórica e Aplicada, v.15, n. 1, p. 161-176, 1999a.

FUNARI, P. P. A. Brazilian archaeology, a reappraisal. In: Politis, G.; Alberti, B. (ed.). Archaeology in Latin America. London \& New York: Routledge, p. 17-37, 1999 b.

FUNARI, P. P.; NEVES, E. G.; PODGORNY, I. Introdução: a primeira reunião internacional de teoria arqueológica na América do Sul: questões e debates. Anais da I Reunião Internacional de Teoria Arqueológica na América do Sul, Revista do Museu de Arqueologia e Etnologia, São Paulo, Suplemento 3, p. 1-12, 1999.

GLASER, B.; HAUMAIER, W.; GUGGENBERGER, G.; ZECH, W. The 'Terra Preta' pehnomenona model for sustainable agriculture in the humid tropics. Naturwissenschaften , $\mathrm{n}$. 88, p. 37-41, 2001. 
GLASER, B. The long term memory of soils - How amazonian dark earths reflect past land use . European Tropical Forest Research Network, n. 37, p. $25-27$ winter 2002/03.

GOLDMEIER, V. A.; SCHMITZ, P. I. A utilização da matéria-prima em sítios précerâmicos. Dédalo, Publicações avulsas n. 1, Anais da IV Reunião Científica da Sociedade de Arqueologia Brasileira - SAB, MAE/USP, São Paulo, p. 388-408, 1989.

GONZÁLEZ, E.M. R. Grupos ceramistas pré-coloniais do Brasil central: origem se desenvolvimento. In: REUNIÃO CIENTÍFICA DA SOCIEDADE DE ARQUEOLOGIA BRASILEIRA, 8., 1996, Porto Alegre. Anais...Porto Alegre: EdiPucrs, 1996, v. 2, p. 233-248.

HACKENBERGER, M.; NEVES, E.; PETERSEN, J. De onde surgem os modelos? As origens e expansões tupis na Amazônia Central. Revista de Antropologia, São Paulo: USP, v. 41, n. 1, p. 69-96, 1998.

HILBERT, K. O problema da cronologia e da interpretação étnica. In: KERN, Arno (Org.). Sociedades Ibero-Americanas: reflexões e pesquisas recentes. Porto Alegre: EDIPUCRS, 2000, p. 373-380. (Coleção História, 35) Conferências apresentadas no III Congresso Internacional de Estudos Ibero-Americanos, Porto Alegre, 1998.

JOHNSEN, H.; OLSEN, B. Hermeneutics and archaeology: on the philosophy of contextual archaeology. American Antiquity, v. 57, n. 3, p. 419-436, 1992.

JONES, S. The archaeology of ethnicity. London and New York: Routledge, 1997.

KIPNIS, R. O uso de modelos preditivos para diagnosticar recursos arqueológicos em áreas a serem afetadas por empreendimentos de impacto ambiental. In: CALDARELLI, S. (org.) Atas do Simpósio Sobre Política Nacional do Meio Ambiente e Patrimônio Cultural. Universidade Católica de Goiás, p. 37-40, 1996.

LEROI-GOURHAN, A. Structures de combustion et structures d'excavation. Séminaire sur les structures d'habitat : témoins de combustion, 1973. Revista do Museu Paulista, São Paulo: USP, Nova Série, v. XXVI, 1979.

LEROI-GOURHAN, A.; BRÉZILLON, M. L habitation magdalenienne n. 1 de Pincevent Près Montereau (Seine-et-Marne). Gallia Préhistoire, Paris, tomo IX, fasc.2, CNRS, p.263385, 1966.

LEROI-GOURHAN, A.; BRÉZILLON, M. Fouilles de Pincevent. Essai d'analyse ethnographique d'un habitat magdalénien. (LA SECTION 36). VII supplément à Gallia Préhistoire, Paris : Édition du Centre National de la Recherche Scientifique, 1972.

LOPONTE, D.; ACOSTA, A. Arqueología guarani en el rio de la Plata. In: CONGRESSO DA SOCIEDADE DE ARQUEOLOGIA BRASILEIRA, 12., 2003, São Paulo. Anais ... São Paulo, 21 a 25 de set. 2003, p. 131.

MACHADO, R. J. M. Pré/para/pluri/multi/interdisciplinaridade. Revista do Professor, Porto Alegre, v.11, n. 44, p. 45, out./dez. 1995.

MARTINS, G.; KASHIMOTO, E. M.; TATUMI, S. H. Datações arqueológicas em Mato Grosso do Sul. Revista do Museu de Arqueologia e Etnologia, São Paulo, n.9, p. 73-93, 1999.

MEGGERS, B.; EVANS, C. Como interpretar a linguagem cerâmica. Manual para arqueólogos. Smithsonian Istitution, Washington D.C., 1970.

MEGGERS, B.; EVANS, C. A utilização de seqüências cerâmicas seriadas para inferir comportamento social. Boletim Série Ensaios, Rio de Janeiro: Instituto de Arqueologia Brasileira, n. 3, set. 1985. 
MEGGERS, B. O paraíso ilusório revisitado. Revista do Museu de Arqueologia e Etnologia (MAE/USP), São Paulo, n. 8, p. 33-55, 1998.

MELIÀ, B. 1987 La tierra sin mal de los guarani: economia y profecia. Suplemento Antropológico, Assunção, Paraguai, n. 22, v. 2, p. 81-97, dez. 1987.

MELIÀ, B.; SAUL, M. V. A.; MURARO, V. F. O guarani: uma bibliografia etnológica. Santo Ângelo: Fundação Missioneira de Ensino Superior - FUNDAMES, Fundação Pró Memória, 1987.

MELLO, P.J. C. Levantamento arqueológico para fins de diagnóstico de bens-pré-históricos, em áreas de implantação de empreendimentos hidrelétricos. In: CALDARELLI, S. (Org.). Atas do Simpósio Sobre Política Nacional do Meio Ambiente e Patrimônio Cultural. Universidade Católica de Goiás, p. 17-21, 1996.

MILDER, S. Arqueologia do sudoeste do Rio Grande do Sul: uma perspectiva geoarqueológica. 173f. Tese (Doutorado em Arqueologia Brasileira). Curso de Pós Graduação em Arqueologia - Museu de Arqueologia e Etnologia da Universidade de São Paulo, 2000.

MILDER, S. E. S.; SOARES, A.L.R. Dados iniciais sobre o Sítio RS-JC-57: metodologia, datações e proposta inicial de interpretação dos dados. Comunicação apresentada no III ENCONTRO DO NÚCLEO REGIONAL SUL DA SOCIEDADE DE ARQUEOLOGIA BRASILEIRA, nov. 2002, não publicado. Porto Alegre: PUCRS.

MILDER, S. E. S.; SOARES, A.L.R. O sítio RS-JC-57: uma nova cronologia para a arqueologia Guarani. III ENCONTRO DO NÚCLEO REGIONAL SUL DA SOCIEDADE DE ARQUEOLOGIA BRASILEIRA, Revista do CEPA, Santa Cruz do Sul, n. 35/36, p.151168, jan.dez. 2002.

MILLER, E. Th. Pesquisas arqueológicas efetuadas no nordeste do Rio Grande do Sul. In: SIMÕES, M. (ed.). Programa Nacional de Pesquisas Arqueológicas 1: resultados preliminares do primeiro ano (1965-1966). Museu Paraense Emílio Goeldi, publicações avulsas n. 6, p. 15-38, 1967.

MILLER, E. Th. Pesquisas arqueológicas efetuadas no nordeste do Rio Grande do Sul (alto Uruguai). In: SIMÕES, M. (ed.). Programa Nacional de Pesquisas Arqueológicas 2: resultados preliminares do segundo ano (1966-1967). Museu Paraense Emílio Goeldi, publicações avulsas n. 10, p. 33-54, 1969.

MILLER, E. Th. História da cultura indígena do Alto Médio-Guaporé (Rondônia e Mato Grosso). Dissertação (Mestrado em História) - Curso de Pós-Graduação em História PUCRS, Porto Alegre, 1983.

MILLER, E. Th. et al. Arqueologia nos empreendimentos hidrelétricos da Eletronorte: resultados preliminares. Brasília: Centrais Elétricas do Norte do Brasil S. A., 1992.

MORAIS, J. L. Salvamento arqueológico na área de influência da PCH Moji-Guaçu. Revista do Museu de Arqueologia e Etnologia. São Paulo: Universidade de São Paulo, n. 5, p.77-98, 1995.

MORAIS, J. L. Perspectivas geoambientais da arqueologia do Paranapanema Paulista, São Paulo. 239 p. Tese (Livre Docência) - Curso de Pós-Graduação em Arqueologia, Museu de Arqueologia e Etnologia da Universidade de São Paulo MAE/USP, 1999.

MORAIS, J. L. Tópicos de Arqueologia da Paisagem. Revista do Museu de Arqueologia e Etnologia (MAE/USP). São Paulo, n. 10, p. 3-30, 2000.

MORAIS, J.L Glossário de termos em uso no projeto Paranapanema, sem data. 
NOELLI, F. S. Sem tekohá não há teko: em busca de um modelo etnoarqueológico da aldeia e da subsistência guarani e sua aplicação a uma área de domínio no delta do Jacuí-RS). 780p. Dissertação (Mestrado em História Ibero-Americana) - Curso de Pós Graduação em História, PUCRS, Porto Alegre, 1993.

NOELLI, F. S. As hipóteses sobre o centro de origem e rotas de expansão dos tupi. Revista de Antropologia, São Paulo, USP, v.39, n. 2, p. 7-53, 1996a.

NOELLI, F. S. Resposta a Eduardo Viveiros de Castro e Greg Urban. Revista de Antropologia, São Paulo, USP, v.39, n. 2, p. 105-118, 1996 b.

NOELLI, F. S. A ocupação humana na região sul do Brasil: arqueologia, debates e perspectivas -1872-2000. Revista USP, n. 44, p. 218-269, dez./jan./fev. 1999/2000.

NOELLI, F. S.; SOARES, A. L. R. Efeitos da conquista européia na terminologia e organização social guarani. Cadernos do METEP - Metodologia e Técnica de Pesquisa, Maringá, v. 9, n. 8, p. 383-397, 1997a.

NOELLI, F. S.; SOARES, A. L. R. Para uma historia das epidemias entre os guaranis. Revista Diálogos - Departamento de Historia - UEM, Maringá, v. 01, p. 165-178, 1997 b.

OLIVEIRA, S. N. A arqueologia guarani: construção e desconstrução da identidade indígena. Dissertação (Mestrado em História) - Unicamp, Campinas, 002.

PABST, E. Critérios de distinção entre Terra Preta e latossolo na região de Belterra e os seus significados para a discussão pedogenética. Boletim do Museu Paraense Emílio Goeldi, Antropologia, v. 7, p.5- 19, jun. 1991.

PALLESTRINI, L. Sítio arqueológico "Jango Luis". Revista do Museu Paulista, Nova Série, v. XVIII, São Paulo, p.25-56, 1968/1969.

PALLESTRINI, L. Sítio Arqueológico Fonseca. São Paulo: Universidade de São Paulo. [Coleção Museu Paulista], 1969.

PALLESTRINI, L. Supra-estruturas e Infra-estruturas arqueológicas no contexto ecológico brasileiro. Revista do Museu Paulista, Nova Série, v. XX, São Paulo, p.7-32, 1972/1973.

PALLESTRINI, L. Interpretação das estruturas arqueológicas em sítios do estado de São Paulo. Coleção Museu Paulista, Série de Arqueologia São Paulo: USP, v.1, 208p, 1975.

RAYMOND, J. S.; DE BOER, W. R.; ROE, P. G. Cumancaya: a peruvian ceramic tradition. Occasional Papers n. 2, Departament of Archaeology, The University of Calgary, 1975.

REDMAN, C.L. Multistage fieldwork and analytical techniques. American Antiquity, v. 38, n. 1, p. 61-79, 1973.

RELATÓRIO de trabalho do primeiro semestre de 1967, referente ao semestre decorrido entre $1^{\circ}$ fevereiro a $1^{\circ}$ de agosto de 1967. Processo CNPQ n. 2503/65. Brochado, arquivo pessoal.

RELATÓRIO de trabalho do segundo semestre de 1971, referente ao semestre decorrido entre 1 de agosto de 1971. Processo CNPQ n. 8611/67. Brochado, arquivo pessoal.

RIBEIRO, P. A. M. Arqueologia do Vale do Rio Pardo, Rio Grande do Sul, Brasil. 654f. Tese (Tese de Doutoramento em História) - PUCRS, Porto Alegre, PUCRS, 1991a.

RIBEIRO, P.A M. 1991b Arqueologia do Vale do Rio Pardo, Rio Grande do Sul, Brasil. Revista do CEPA, v. 18, n. 21.Santa Cruz do Sul: UNISC, 1991b. 
RIBEIRO, P. A. M. 1996. Levantamentos arqueológicos no médio e alto Jacuí, RS - Brasil. Revista Biblos, Rio Grande, v. 8, p. 9-42, 1996. [Publicado anteriormente com o mesmo nome em 1991 como relatório final para a CEEE].

ROGGE, J. Adaptação na floresta Saubtropical: a tradição tupiguarani no médio rio Jacuí e no Rio Pardo. Documentos 6, São Leopoldo: Unisinos, 1996.

ROGGE, J. Função e permanência em assentamentos litorâneos da tradição tupiguarani: um exemplo do litoral central do rio grande do sul. In: REUNIÃO DA SOCIEDADE DE ARQUEOLOGIA BRASILEIRA, 9., 1997. Anais... Rio de Janeiro: Sociedade de Arqueologia Brasileira, 1997.

ROGGE, J. Assentamentos litorâneos da tradição tupiguarani: projeto Quintão. Revista do CEPA, Santa Cruz do Sul, v. 23. n. 29, p.215-217, jan.jun. 1999.

SAHLINS, M. Ilhas de história. Rio de Janeiro: Jorge Zahar, 1990.

SCHIAVETTO, S. N. O. A Arqueologia Guarani. Construção e desconstrução da identidade indígena. São Paulo: Annablume: FAPESP, 2003.

SCHMITZ, P. I. Paradeiros guaranis em Osório (Rio Grande do Sul). Pesquisas, IAP, p.113143, 1958.

SCHMITZ, P.I. O guarani no Rio Grande do Sul. Boletim do MARSUL, Taquara, n. 2, nov. 1985a.

SCHMITZ, P.I. Território de domínio: em grupos tupiguarani: considerações sobre o médio e alto Jacuí, RS. Boletim do MARSUL, Taquara, n. 3, p.45-52, nov. 1985b.

SCHMITZ, P. I. Migrantes da Amazônia: a tradição tupiguarani. Documentos 5, Pré-história do Rio Grande do Sul. São Leopoldo: IAP-Unisinos, p. 31-66, 1991.

SCHMITZ, P.I. Migrantes da Amazônia: a tradição tupiguarani. In: KERN, A. A. (Org.). Arqueologia pré-histórica do Rio Grande do Sul. 2. ed. Porto Alegre: Mercado Aberto, 1997.

SCHMITZ, P. I. O guarani: história e pré-história. In: TENÓRIO, M. C. (Org.). Pré-história da terra brasilis. Rio de Janeiro: UFRJ, 1999.

SCHMITZ, P. I.; BARBOSA, A.S.; RIBEIRO, M. B. Os cultivadores do Planalto e do Litoral. Temas de Arqueologia Brasileira. Goiânia: Instituto de Pré-História e Antropologia, 1978/79/80.

SCHMITZ, P. I.; RIBEIRO, P. A. M.; FERRARI, J. Salvamento arqueológico no médio Jacuí, RS - Barragem Dona Francisca. São Leopoldo: IAP, 18 p. [Relatório para a Companhia Estadual de Energia Elétrica], 1981.

SCHMITZ, P. I.; BROCHADO, J. P. Petroglifos no estilo pisadas no centro do Rio Grande do Sul. Pesquisas, Antropologia n. 34,p. 03-47, 1982.

SCHMITZ, P.I.; ARTUSI, L.; JACOBUS, A.; GAZZANEO, M.; ROGGE, J. ; MARTIN, H.; BAUMHARDT, G. Uma aldeia tupiguarani. Projeto Candelária, RS. Documentos, n. 04, p. 1135. São Leopoldo: IAP, 1990.

SCHMITZ, P. I.; ROGGE, J.; ARNT, F. Sítios arqueológicos do médio Jacuí, RS.

Documentos 8, São Leopoldo: Unisinos, 2000.

SHANKS, M.; HODDER, I. Processual, postprocessual and interpretative archaeologies. In: HODDER, I.; SHANKS, M.; ALEXANDRI, A.; BUCHLI, V.; CARMAN, J.; LAST, J.;

LUCAS, G. Interpreting archaeology: finding meaning in the past. London and New York:

Routledge, 1995, 275 p. 
SILVA, S. B. Etnoarqueologia dos grafismos Kaingang: um modelo para a compreensão das sociedades Proto-Jê Meridionais. Tese de Doutorado (Doutorado em Antropologia) PPGAS/USP, São Paulo, 2001.

SILVA, S. B. Dualismo e cosmologia Kaingang: o xamã e o domínio da floresta. Horizontes Antropológicos, Porto Alegre, ano 8, n. 18. p. 189-209, dezembro de 2002.

SIMÕES, M. 1972 Índice das fases arqueológicas brasileiras 1950-1971. Belém: Museu Paraense Emílio Goeldi, publicações avulsas n.18, 1972.

SOARES, A. L. R. Organização sócio-política guarani: aportes para a investigação arqueológica. 256 p. Dissertação (Mestrado em História, Área de Concentração em Arqueologia ) - PUCRS, Porto Alegre, 1996.

SOARES, A. L. R. Guarani: organização social e arqueologia. Porto Alegre: EdiPUCRS, 1997. [Série Arqueologia 4].

SOARES, A. L. R. Revisitando a organização sócio-política guarani: pode-se fazer etnohistória e arqueologia? In: JORNADAS INTERNACIONALES SOBRE LAS MISIONES JESUÍTICAS., 7., 1998. Anais... Resistência, Chaco, Argentina: Instituto de Investigaciones Geohistéoricas - CONICET e Facultad de Humanidades - UNNE, p. 569-582,1998.

SOARES, A. L. R. Os horticultores guaranis: problemáticas, perspectivas e modelos. In: QUEVEDO, J. (Org.). Rio Grande do Sul: quatro séculos de História . Porto Alegre: Martins Livreiro, p. 61-101, 1999.

SOARES, A. L. R.; GARLET, I. Parcialidades guarani: em busca de uma visão diacrônica. Histórica, Revista da Ass. dos Pós-Graduandos em História da PUCRS. Porto Alegre, n.03, p. 53-58, 1998.

SOARES, A.L.R.; MILDER, S.E.S. Arqueologia da morte: enterro de índio, vida de jesuíta, história que se escreve em cacos . Cadernos do CEOM, Ano 16, n. 16. Chapecó: Argos, p. 275-298, 2003.

SUSNIK, B. Dispersión tupi-guarani pré-histórica: ensayo analítico. Asunción: Museo Etnográfico Andrés Barbero, 1975.

SUSNIK, B. Los aborígenes de Paraguay: etnohistória de los guaraníes - época Colonial. Tomo II. Asunción: Museo Etnográfico Andrés Barbero, 1979/80.

SUSNIK, B. 1983 Los aborígenes de Paraguay: cicb vital y estructura social. Tomo V. Asunción: Museu Etnografico Andrés Barbero, 1983.

TERMINOLOGIA. Terminologia arqueológica brasileira para a cerâmica. Cadernos de Arqueologia. Paranaguá: Universidade Federal do Paraná, Ano 1, n. 1, 1976.

THOMAS, J. A materialidade e o social. Revista do Museu de Arqueologia e Etnologia, São Paulo, Suplemento 3, p. 15-20, 1999. [Anais da I Reunião Internacional de Teoria Arqueológica na América do Sul].

URBAN, G. On the geographical origins and dispersion of tupian Languages. Revista de Antropologia, São Paulo: USP, v.39, n. 2, p. 61-104, 1996.

VIVEIROS DE CASTRO, E. Comentário ao artigo de Francisco Noelli. Revista de Antropologia, São Paulo: USP, v. 39, n. 2, p. 55-60, 1996.

WATANABE, S.; SENGUPTA, D. Datação de cerâmicas arqueológicas com as técnicas de termoluminescência oticamente estimulada (OSL) e ressonância paramagnética eletrônica 
(ESR). Revista do Museu de Arqueologia e Etnologia, São Paulo, Suplemento 2, p. 161-166, 1997.

YOFFE, N. Teoria sócio-evolucionista e seus descontentes. In: Anais da VIII REUNIÃO CIENTÍFICA DA SOCIEDADE DE ARQUEOLOGIA BRASILEIRA, 8., 1996, Porto Alegre. Anais... Porto Alegre: EdiPucrs, p. 107-126, 1996. 


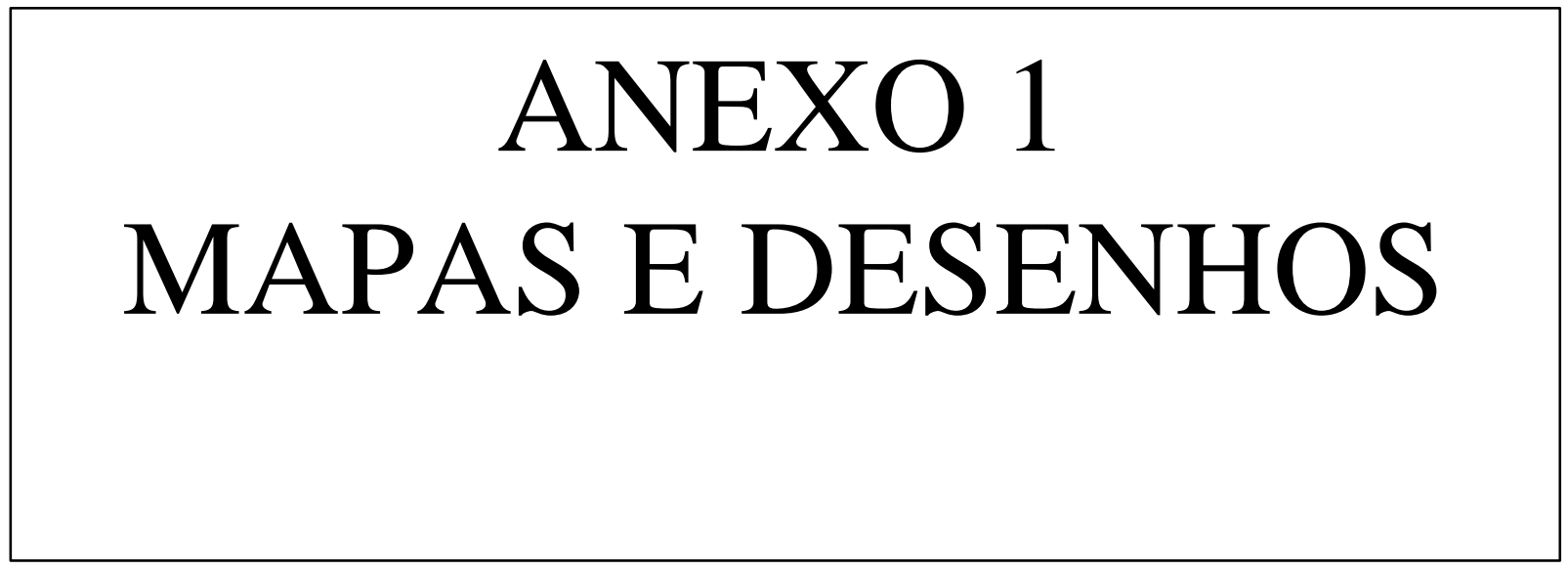




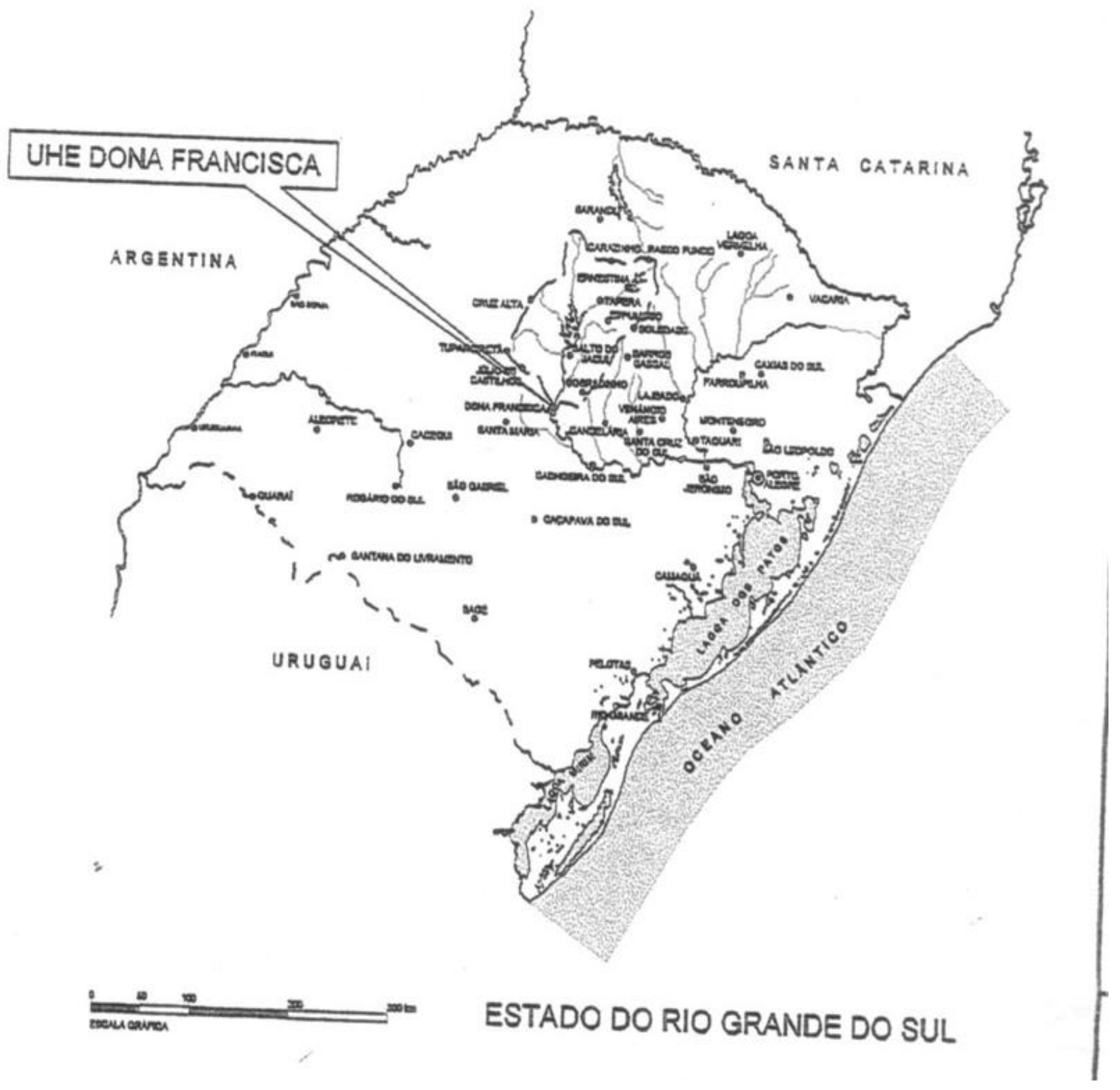

Mapa 1: Mapa de localização da Usina Hidrelétrica (UHE) de Dona Francisca, Rio Grande do Sul, Brasil (fonte: Grupo Industrial Dona Francisca - UHE Dona Francisca, Projeto Básico. Companhia Estadual de Energia Elétrica CEEE). 


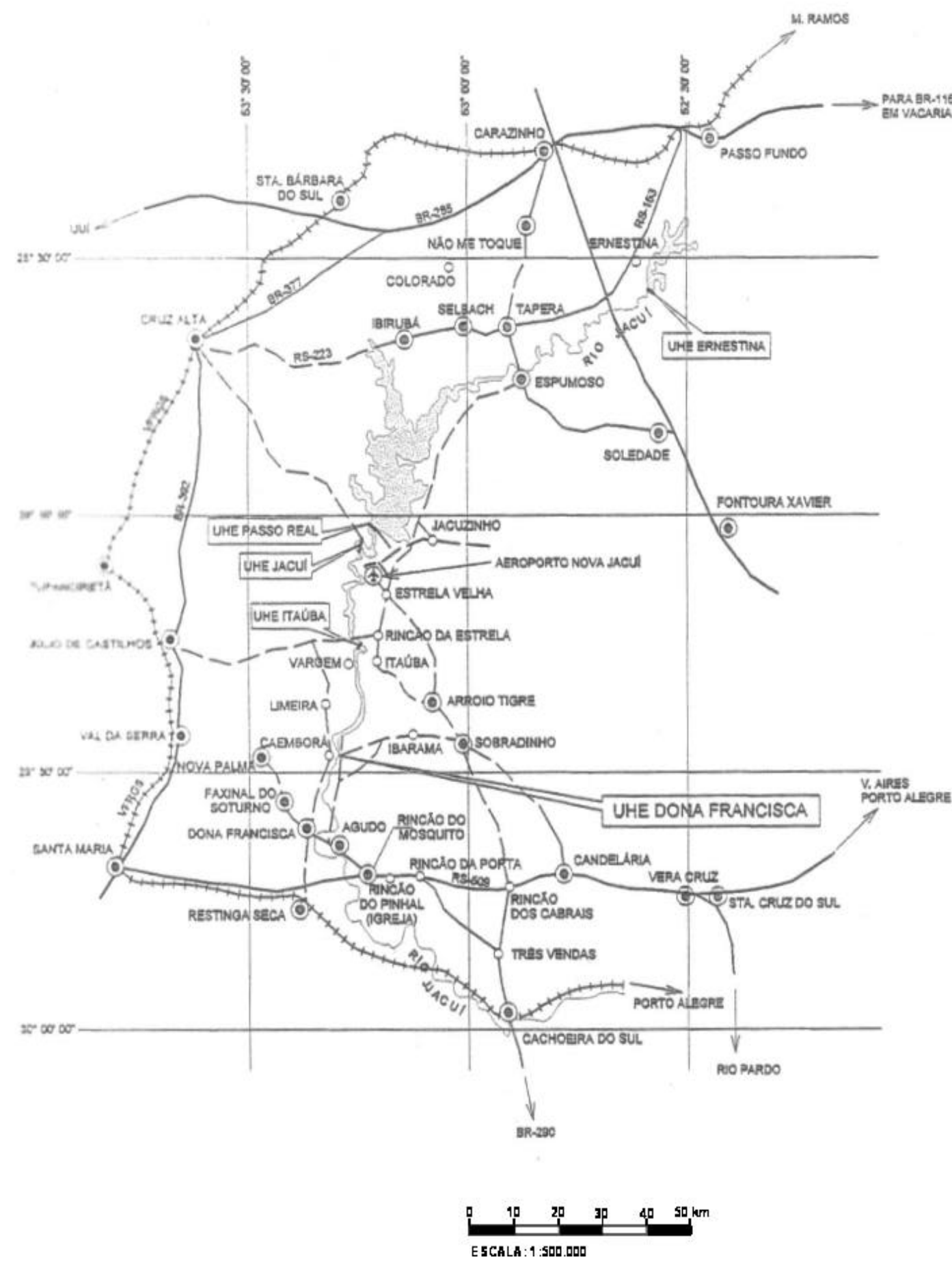

Mapa 2: Localização da UHE Dona Francisca e municípios próximos (fonte: Grupo Industrial Dona Francisca - UHE Dona Francisca, Projeto Básico. Companhia Estadual de Energia Elétrica - CEEE). 


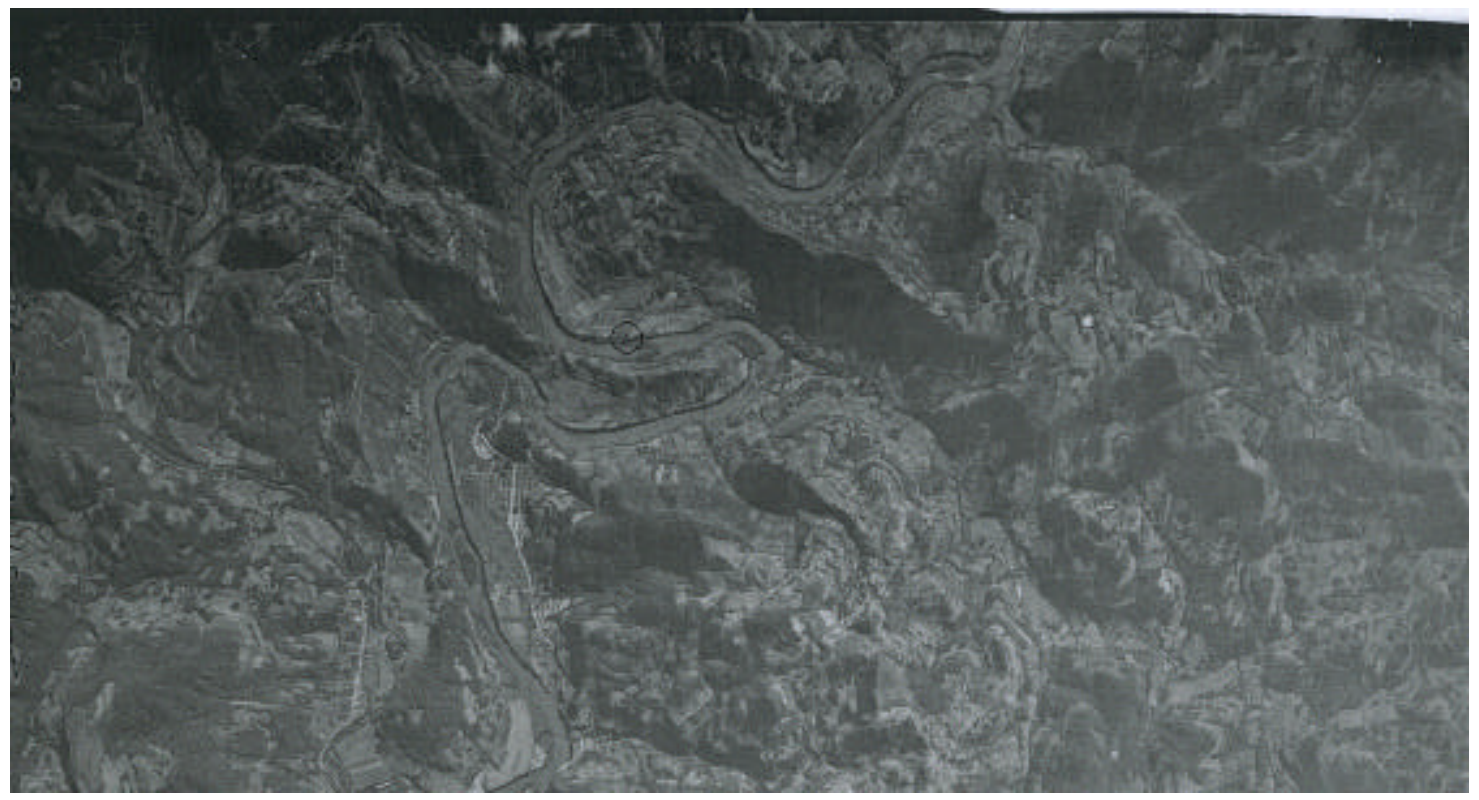

Foto 1: Foto aérea do local das atividades. Escala 1:60000. O ponto no centro do círculo indica o sítio arqueológico.

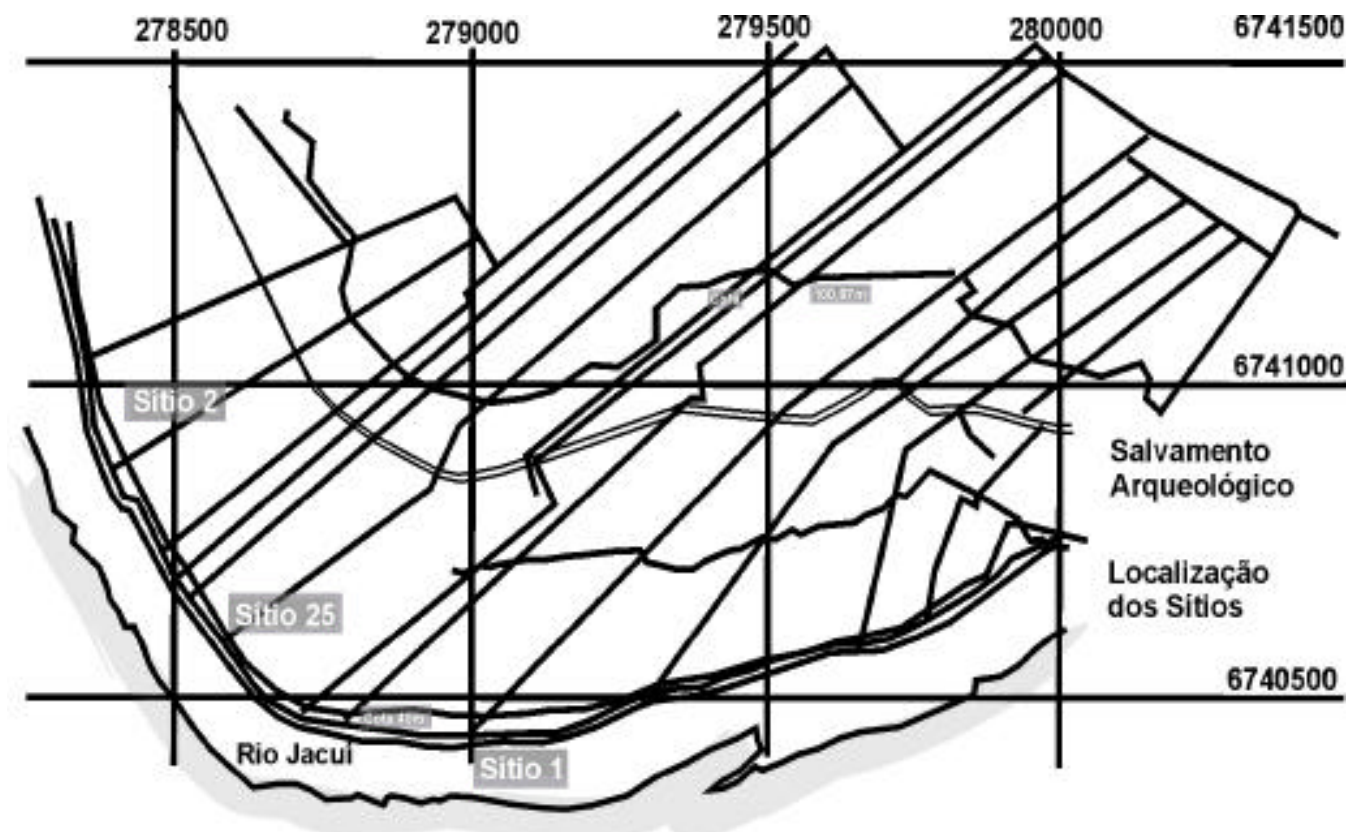

Mapa 3: Coordenadas UTM do śtio RS-JC-57 (sítio 1) e outros śtios guaranis próximos (sítios 2 e 25) ( acervo LEPA/UFSM, modificado pelo autor). 


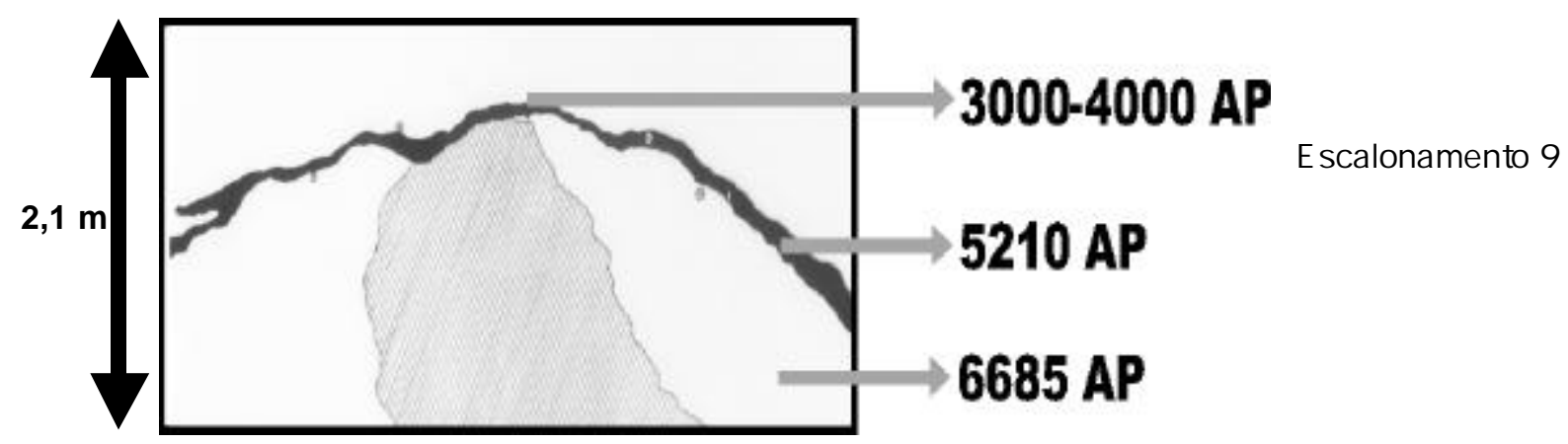

Legenda

Solo antropogênico

\section{Arenoso}

Escalonamento 5

\section{Siltico-argiloso}

\#弗 Areno-argiloso
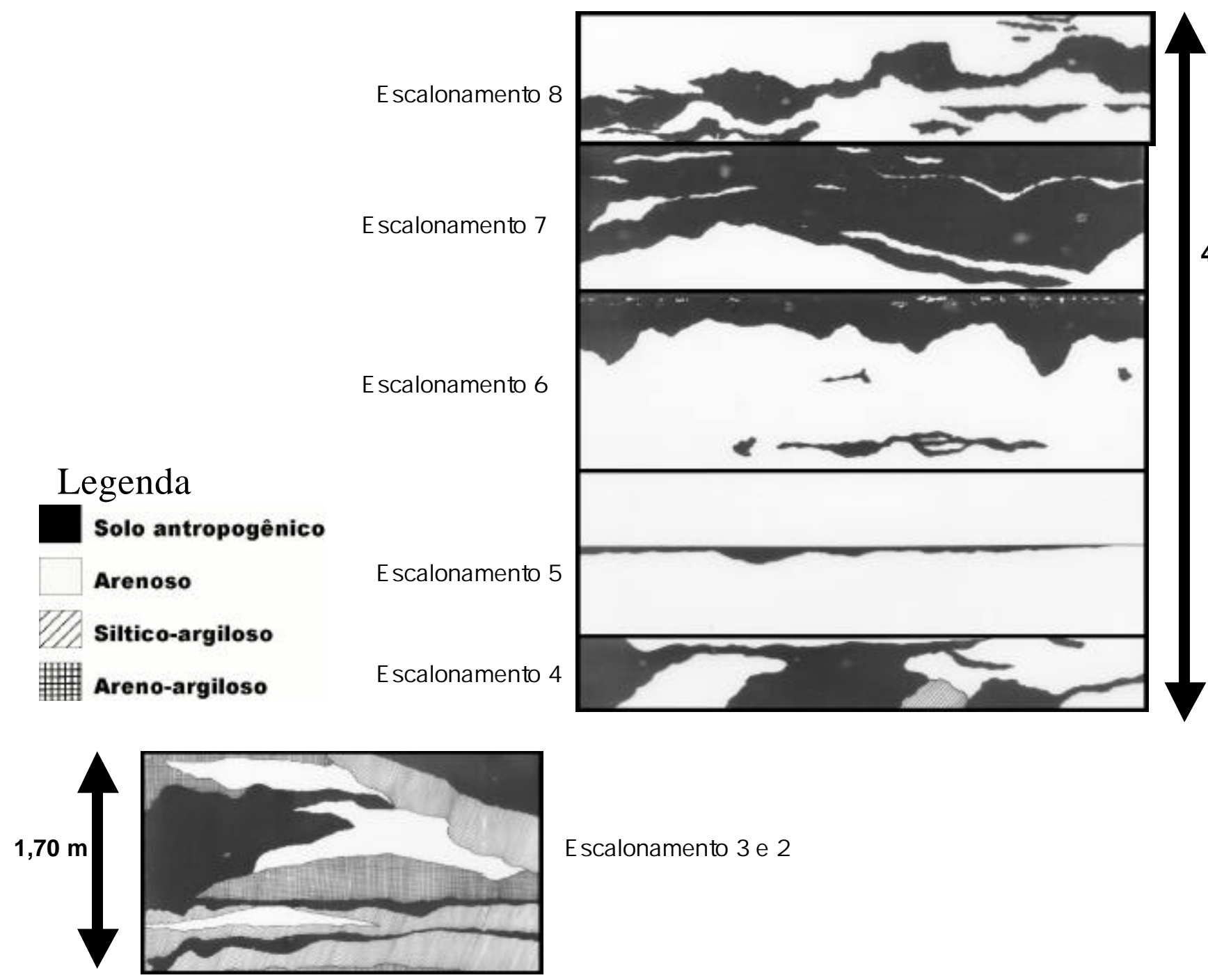

Escalonamento 3 e 2
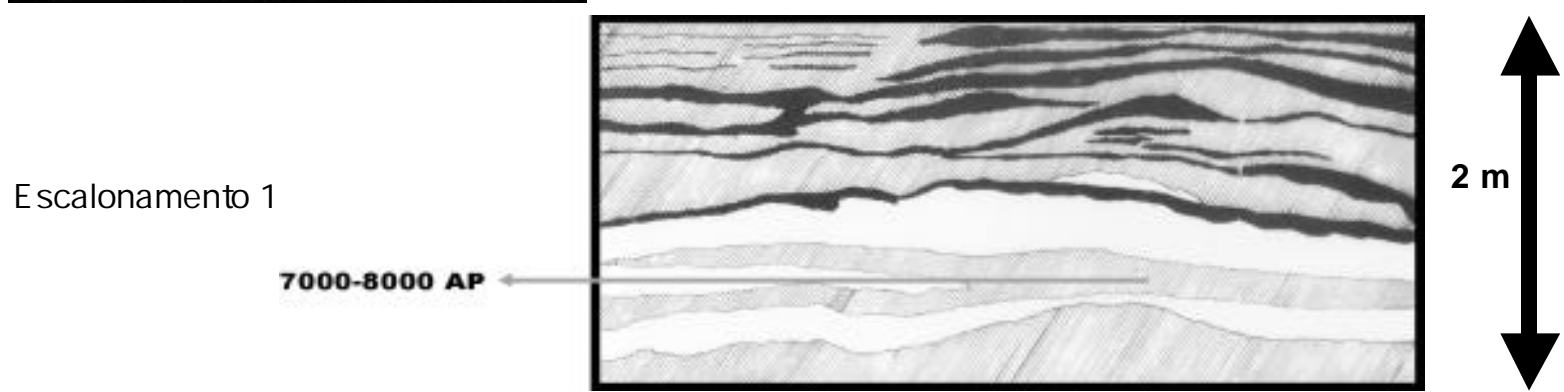

Desenho 2: Escalonamentos realizados no talude do rio e datações realizadas pelo LACIFID nos sedimentos antropogênicos e não-antropogênicos (acervo LEPA/UFSM, modificado pelo autor). 


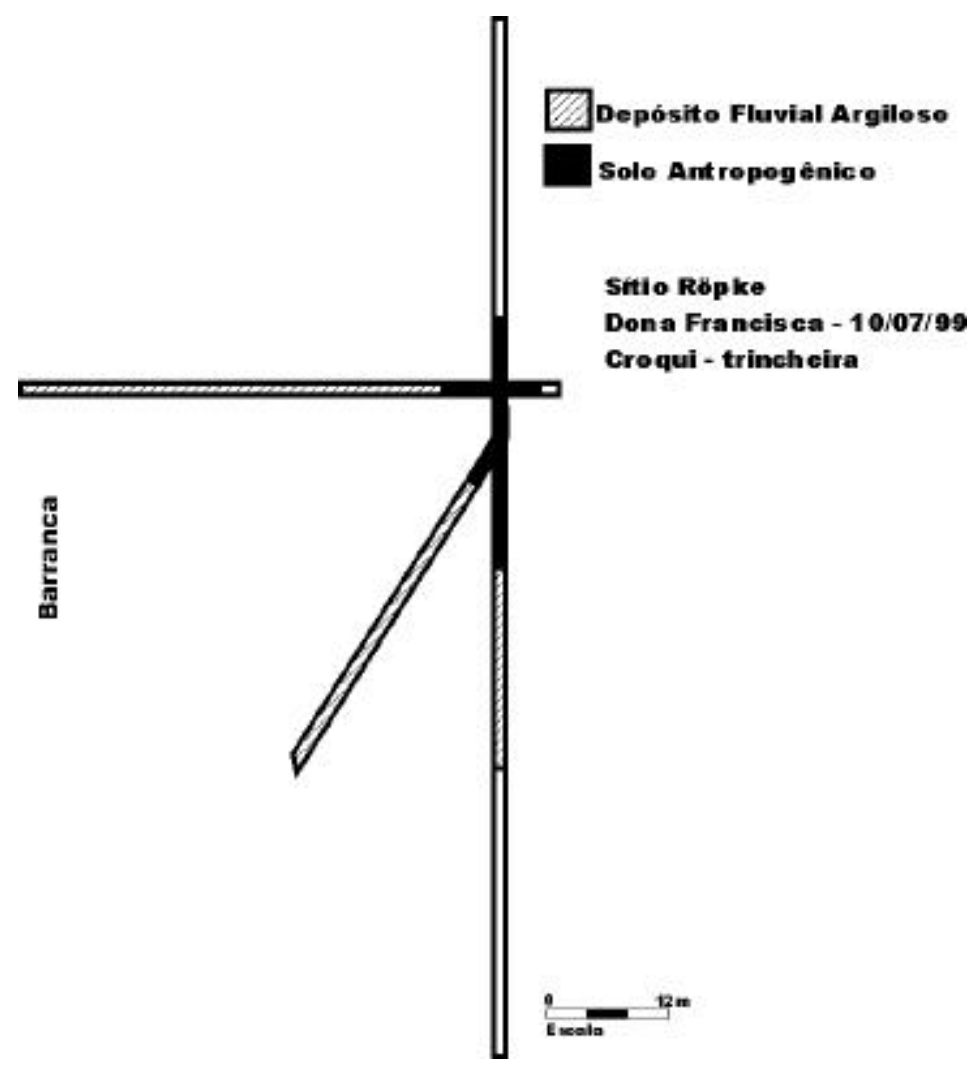

Desenho 3: Abertura das trincheiras multidirecionais e localização do núcleo de solo antropogênico (croqui: acervo LEPA/UFSM, modificado pelo autor).

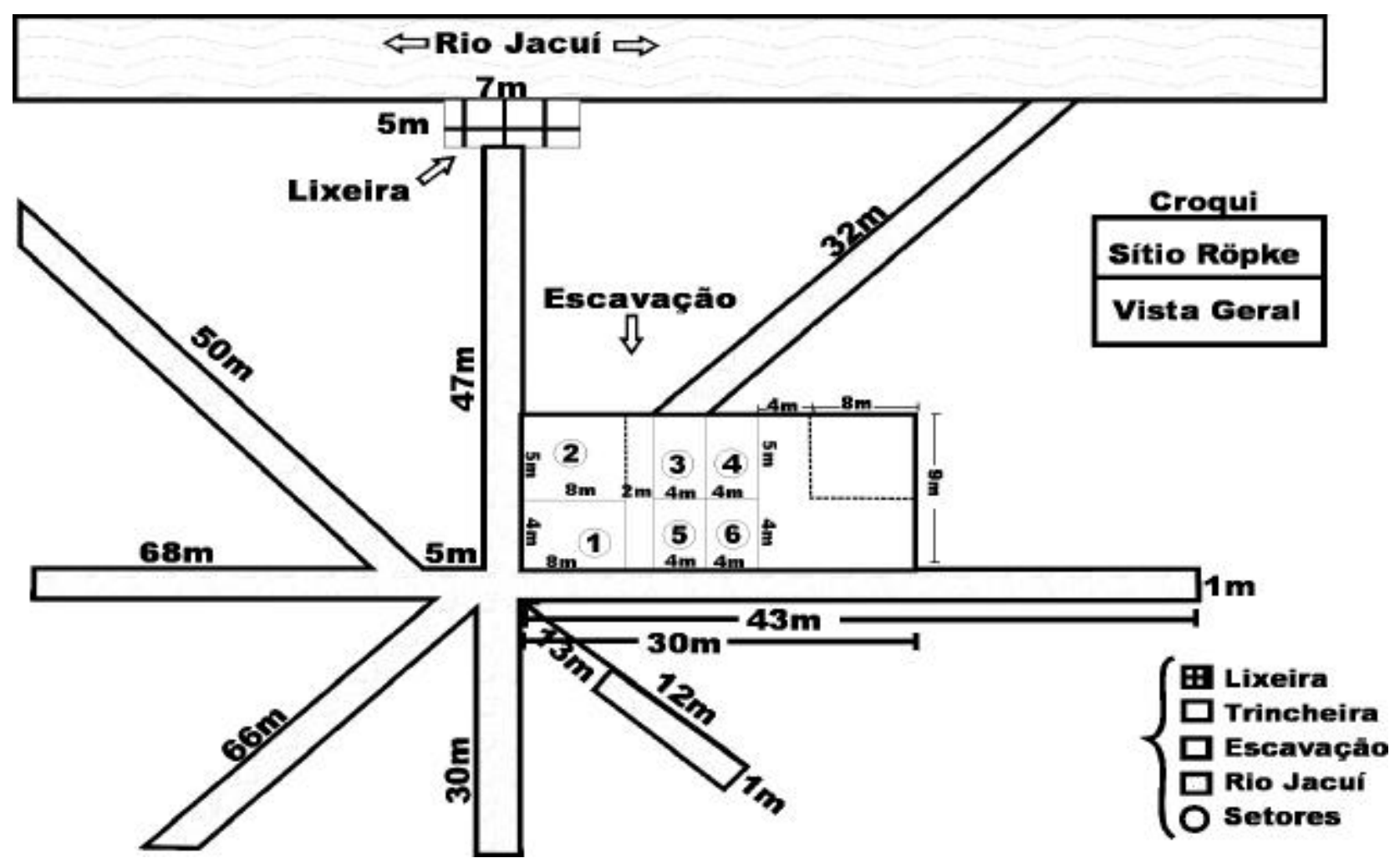

Desenho 4: Croqui da localização do NSA em relação a área de descarte (acervo LEPA/UFSM, modificado pelo autor). 


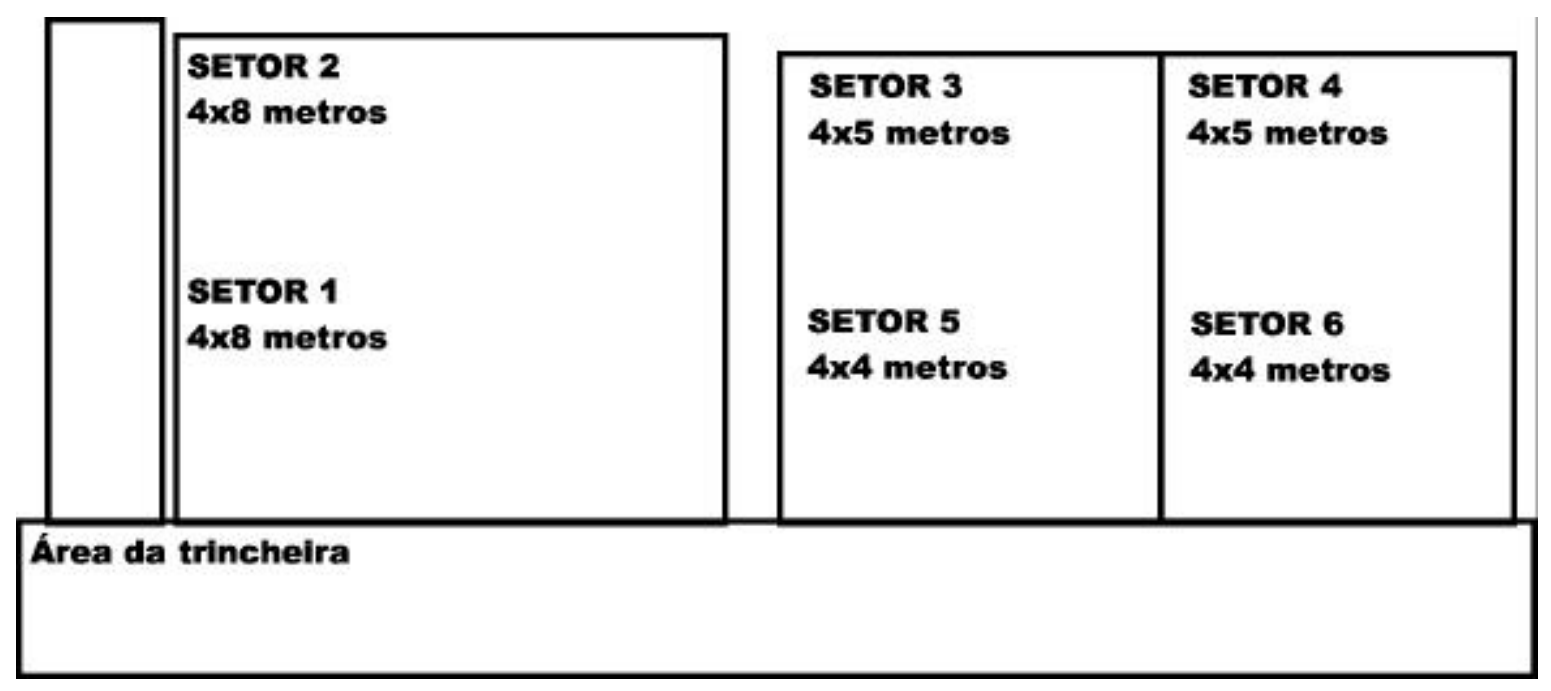

Desenho 5: Croqui dos setores escavados pelas equipes (acervo LEPA/UFSM, modificado pelo autor).

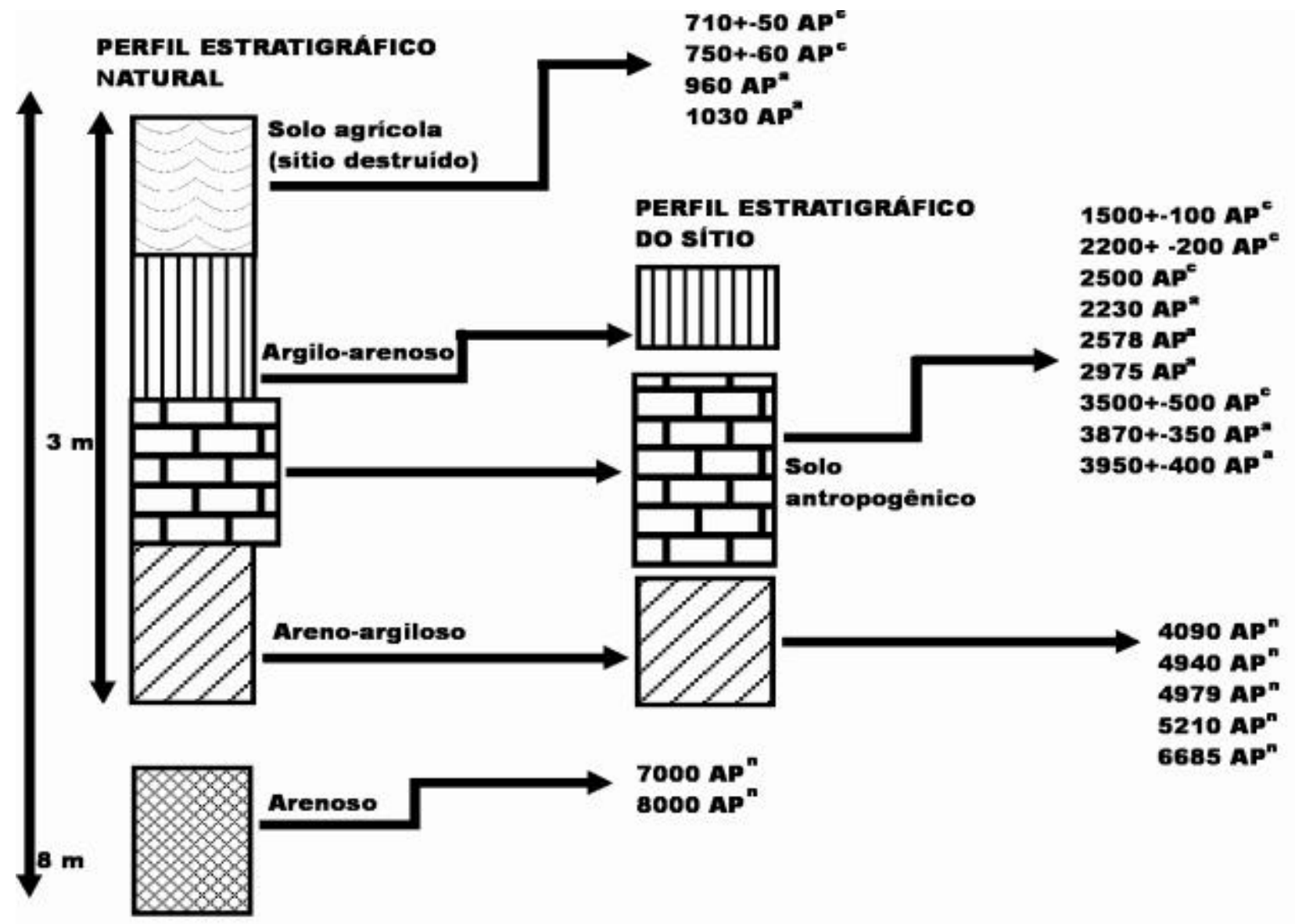

\section{Desenho Perfil estratigráfico e datações por TL e OSL}

Dataçâo por fragmento Cerâmica - $c$ Dataçâo de Sedimento antropogênicos - a Dataçāo de Sedimentos naturais - $n$ 


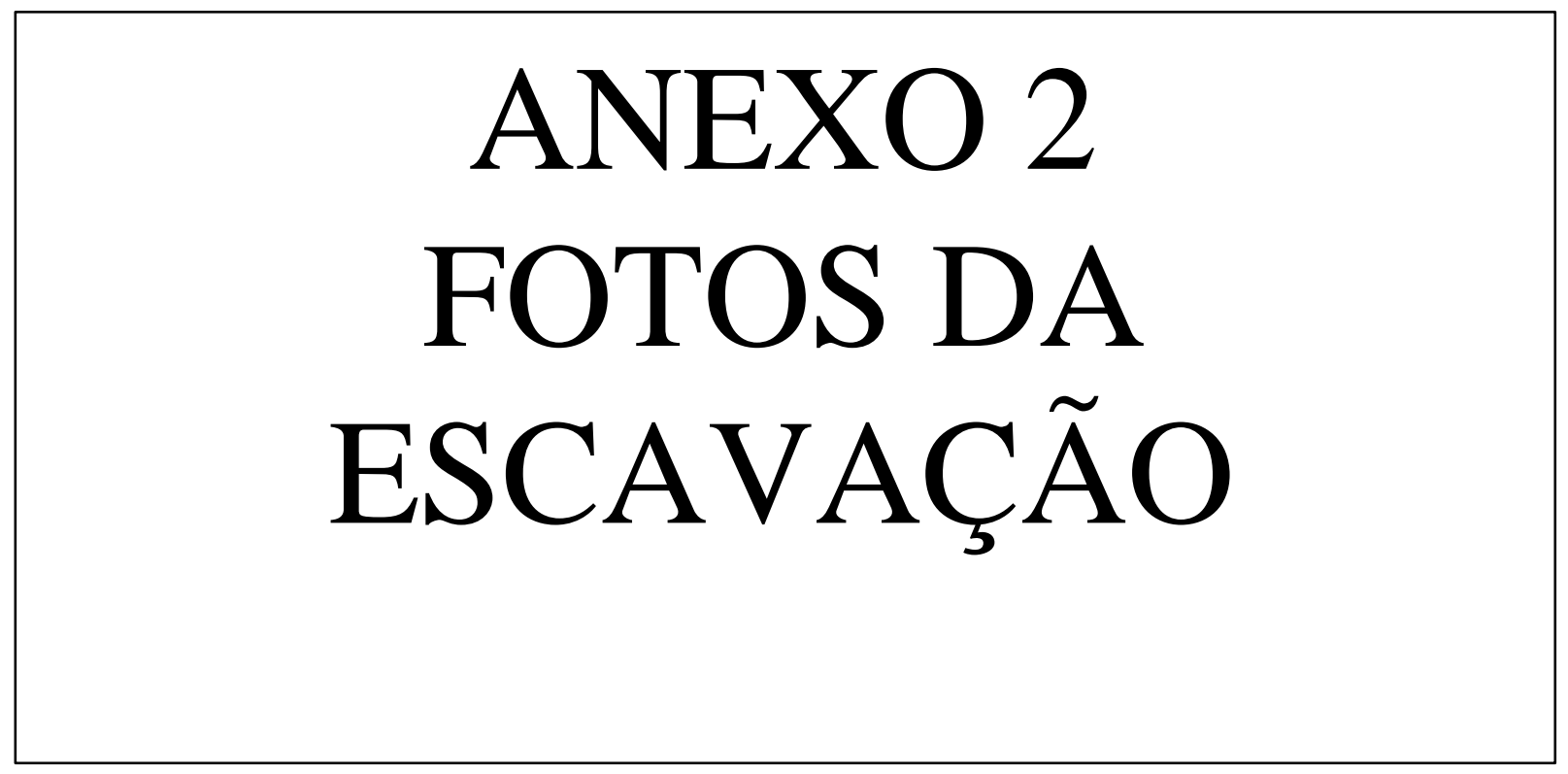




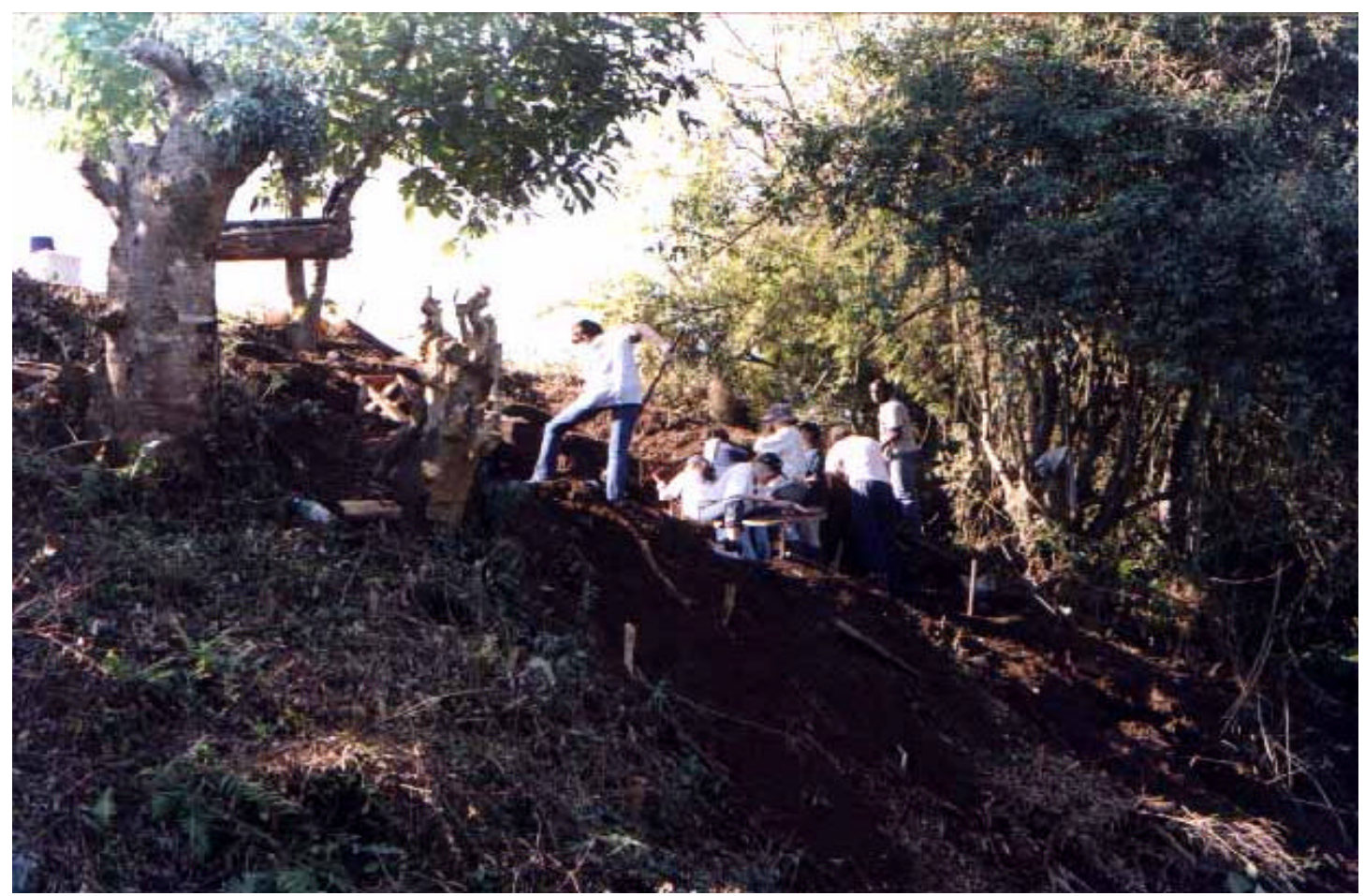

Foto 1 : Escavação da área de descarte. Vista lateral do talude do rio (foto Acervo LEPA/UFSM).

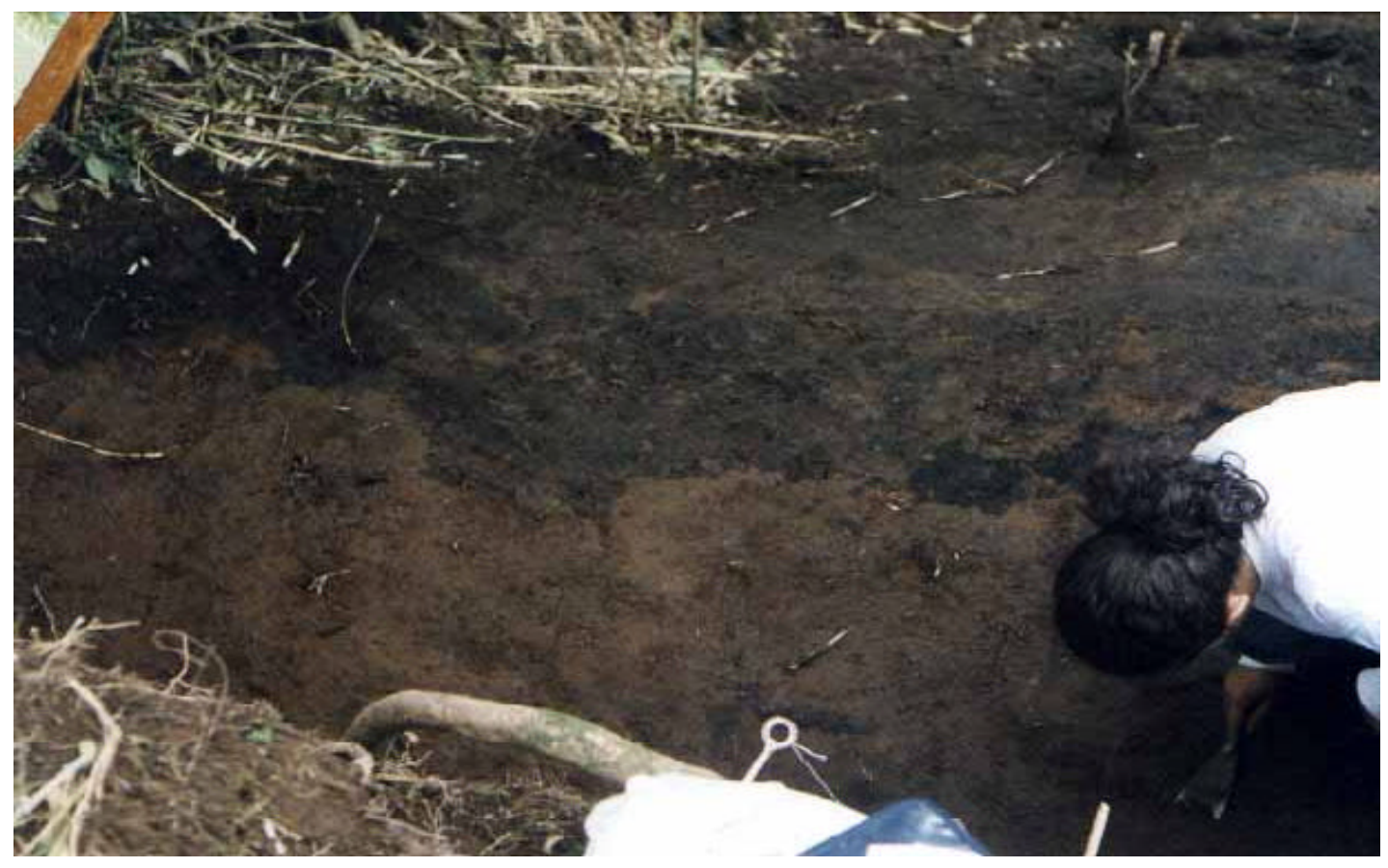

Foto 2 : Escavação da área de descarte. Vista de cima para baixo. Observe-se a dispersão do NSA (foto Acervo LEPA/UFSM). 


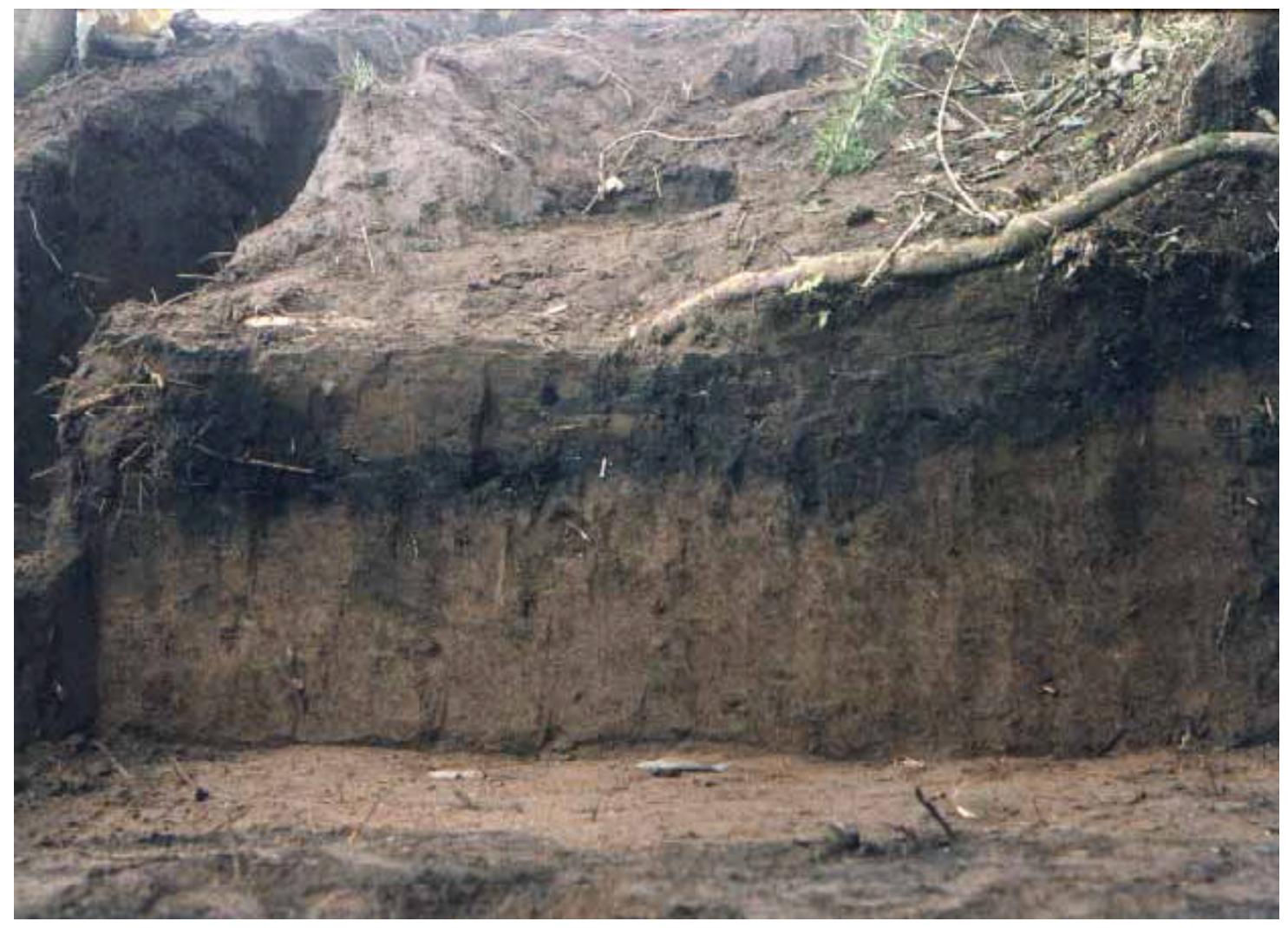

Foto 3 : Perfil do talude e retificação do escalonamento 8 (foto Acervo LEPA/UFSM).

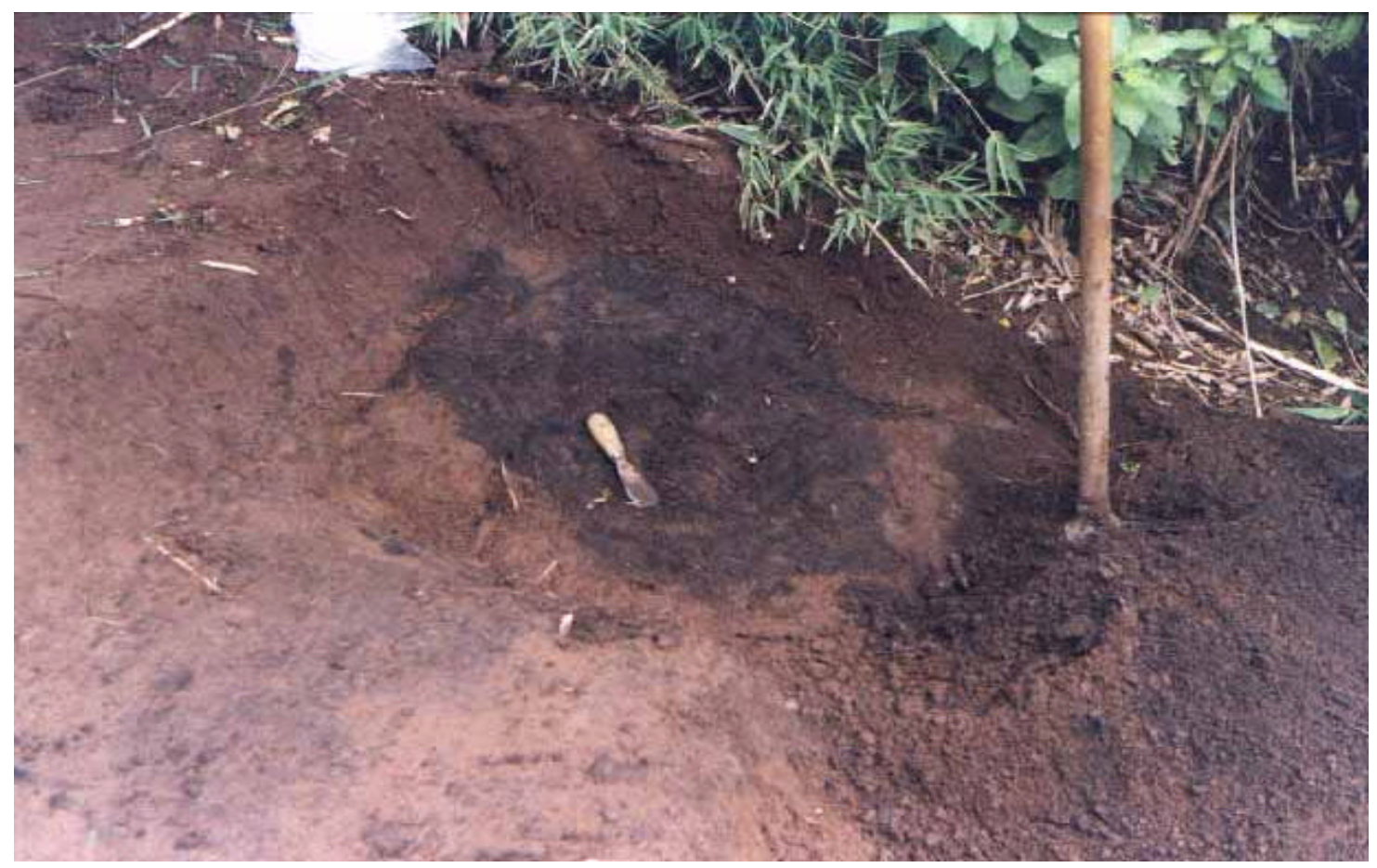

Foto 4 : Escavação da área de descarte. Evidenciação da lente de solo antropogênico (foto Acervo LEPA/UFSM). 


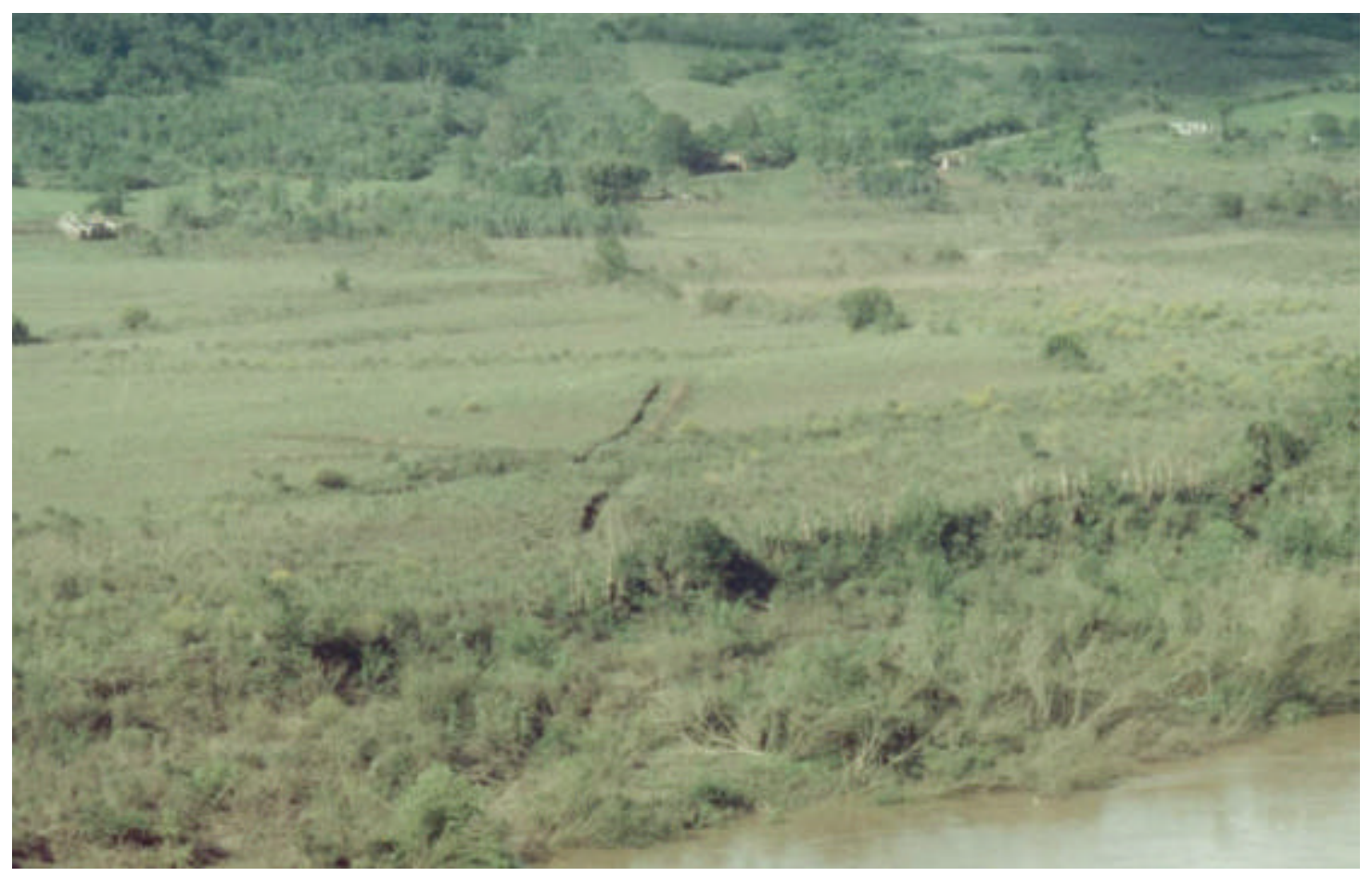

Foto 5: Abertura das trincheiras multidirecionais a partir da área de descarte(foto André Soares).

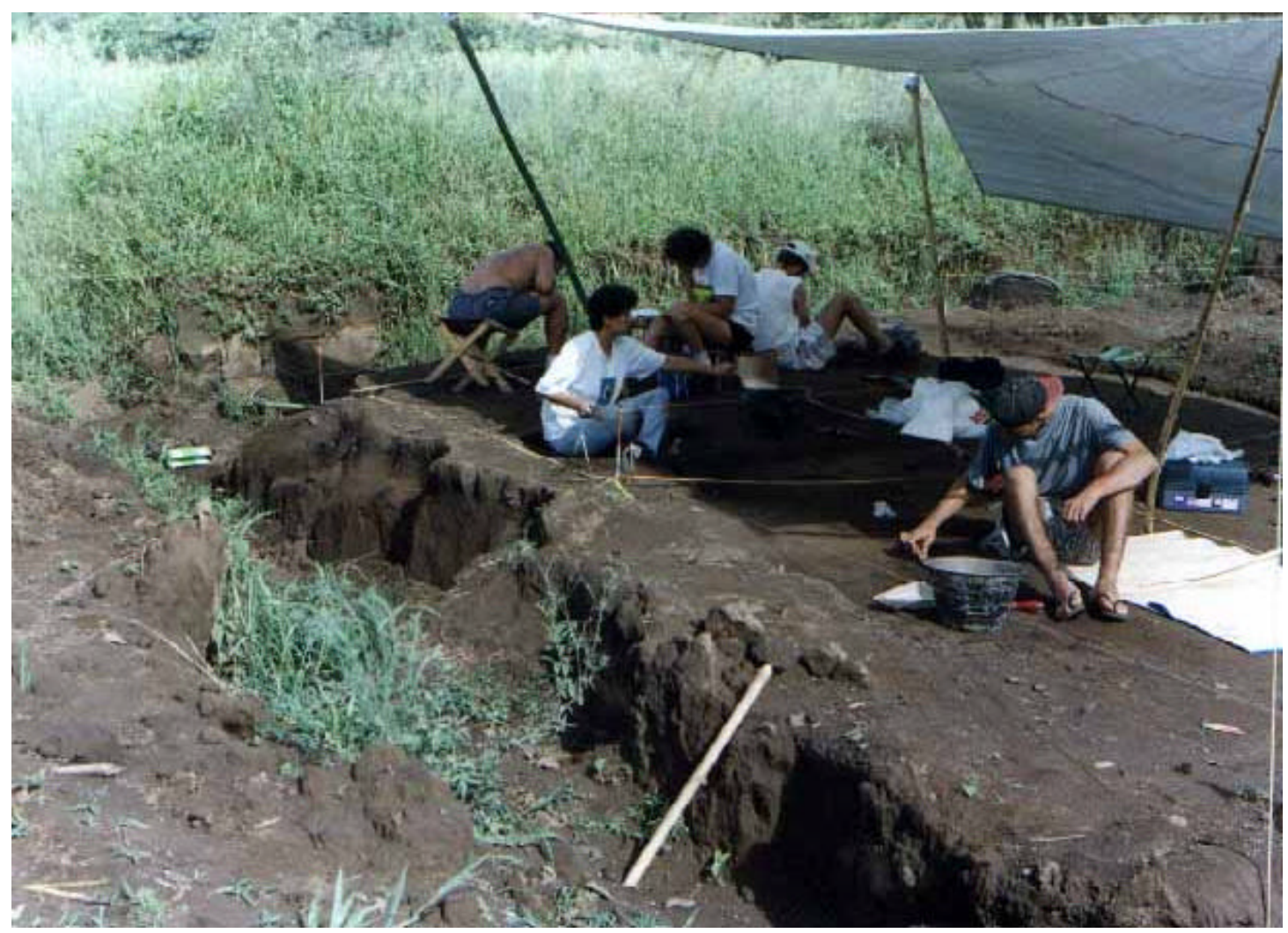

Foto 6: Escavação da área de habitação (foto Acervo LEPA/UFSM). 


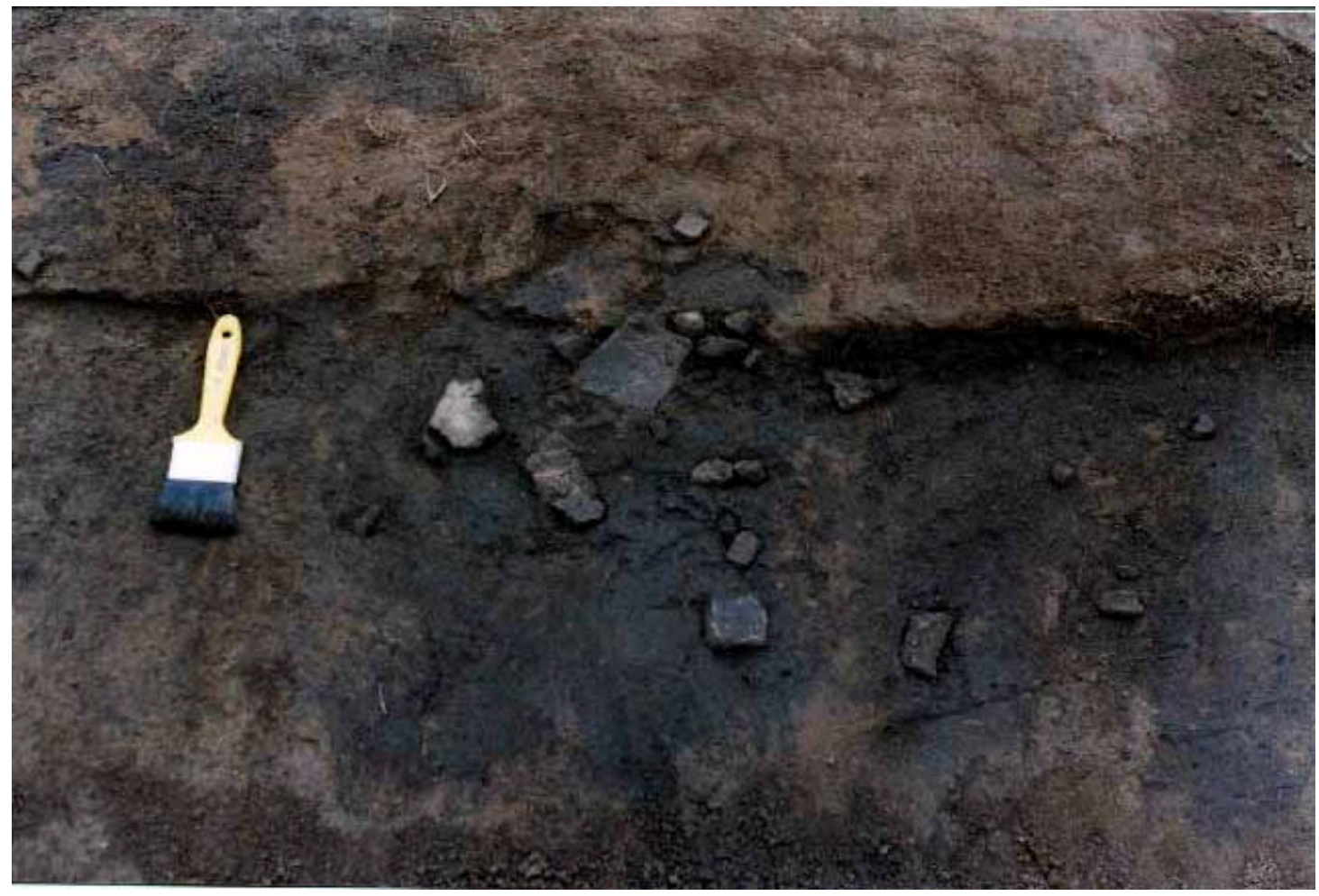

Foto 7: fogueira localizada no setor 1 (foto Acervo LEPA/UFSM).

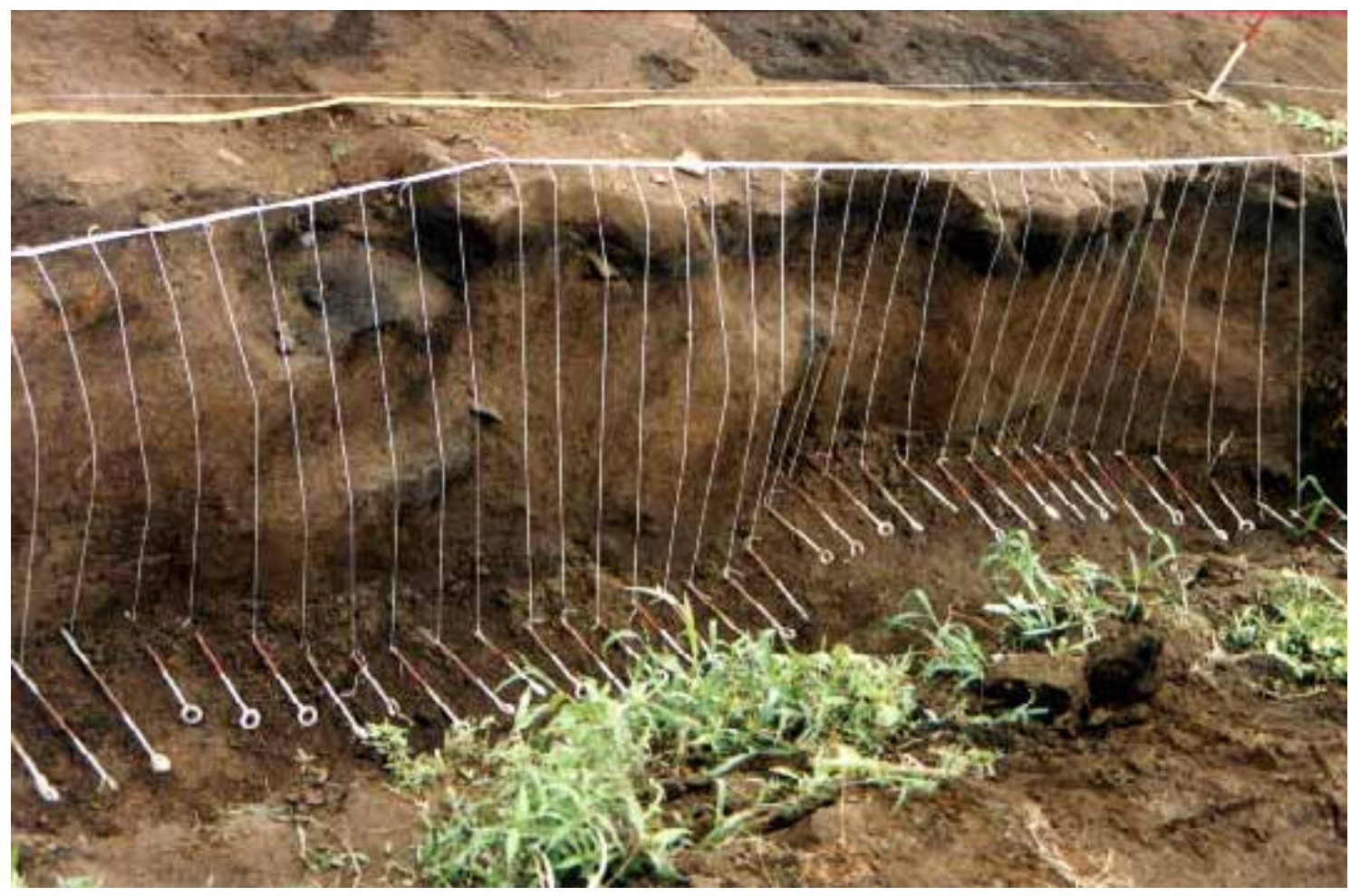

Foto 8: Documentação da estratigrafia do setor 1 (foto Acervo LEPA/UFSM). 


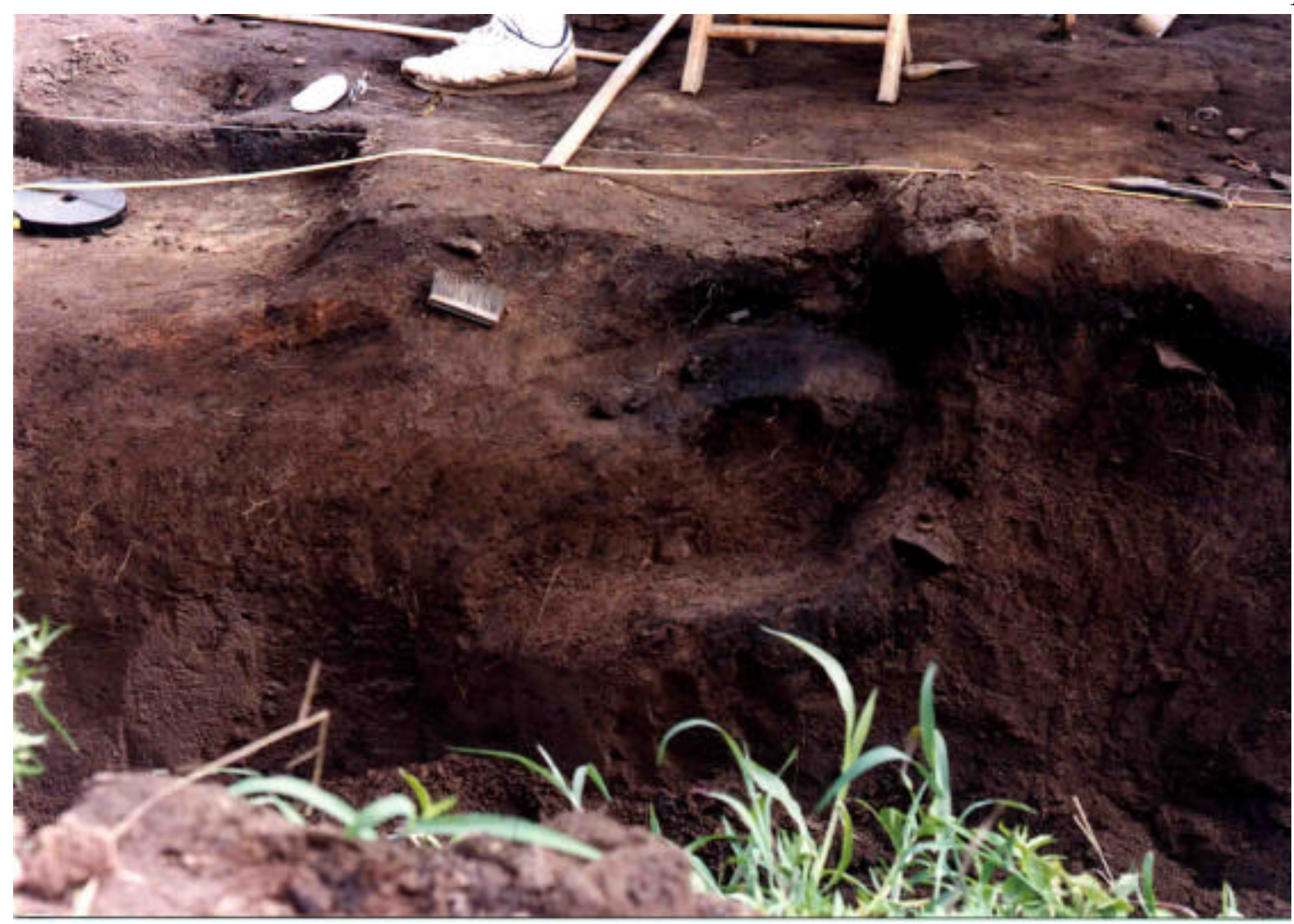

Foto 9: Escavação de uma depressão (forno tipo polinésio?) (foto Acervo LEPA/UFSM).

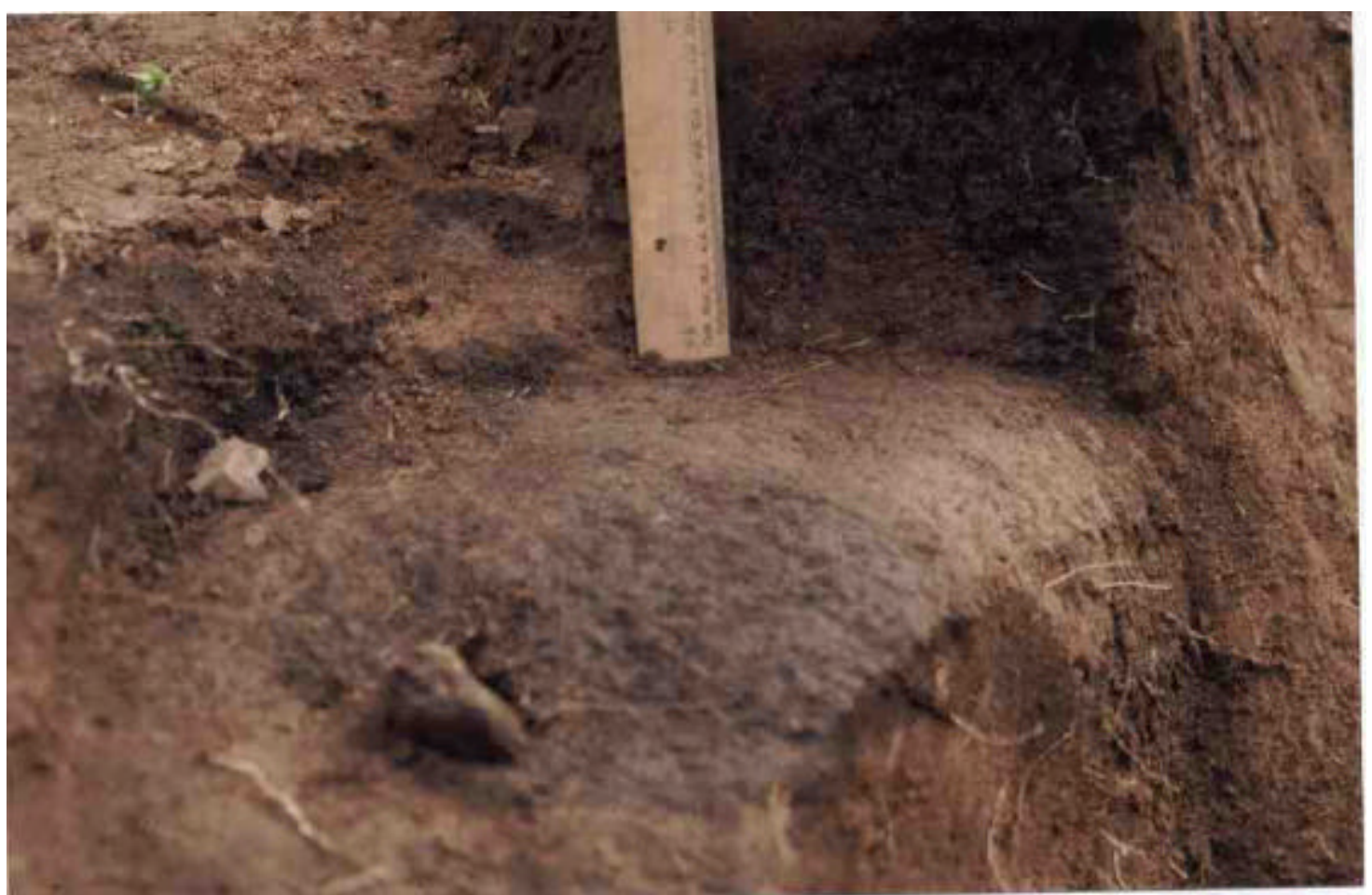

Foto 10: Idem anterior, de perfil. Existe referência a fogueiras com depressão côncava em sítios Guaranis (foto André Soares). 


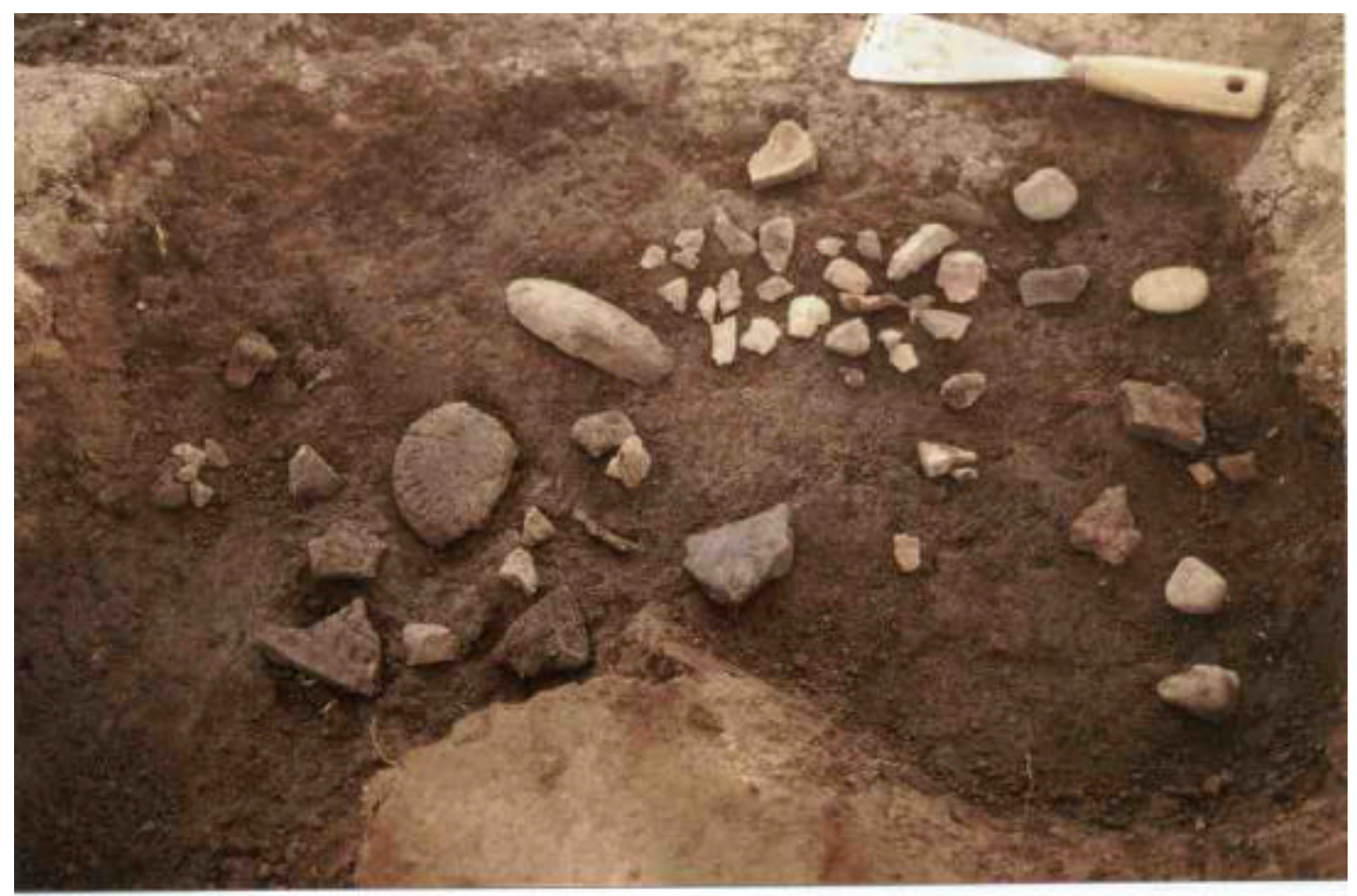

Foto 11 : Fogueira no setor 1 (foto André Soares).

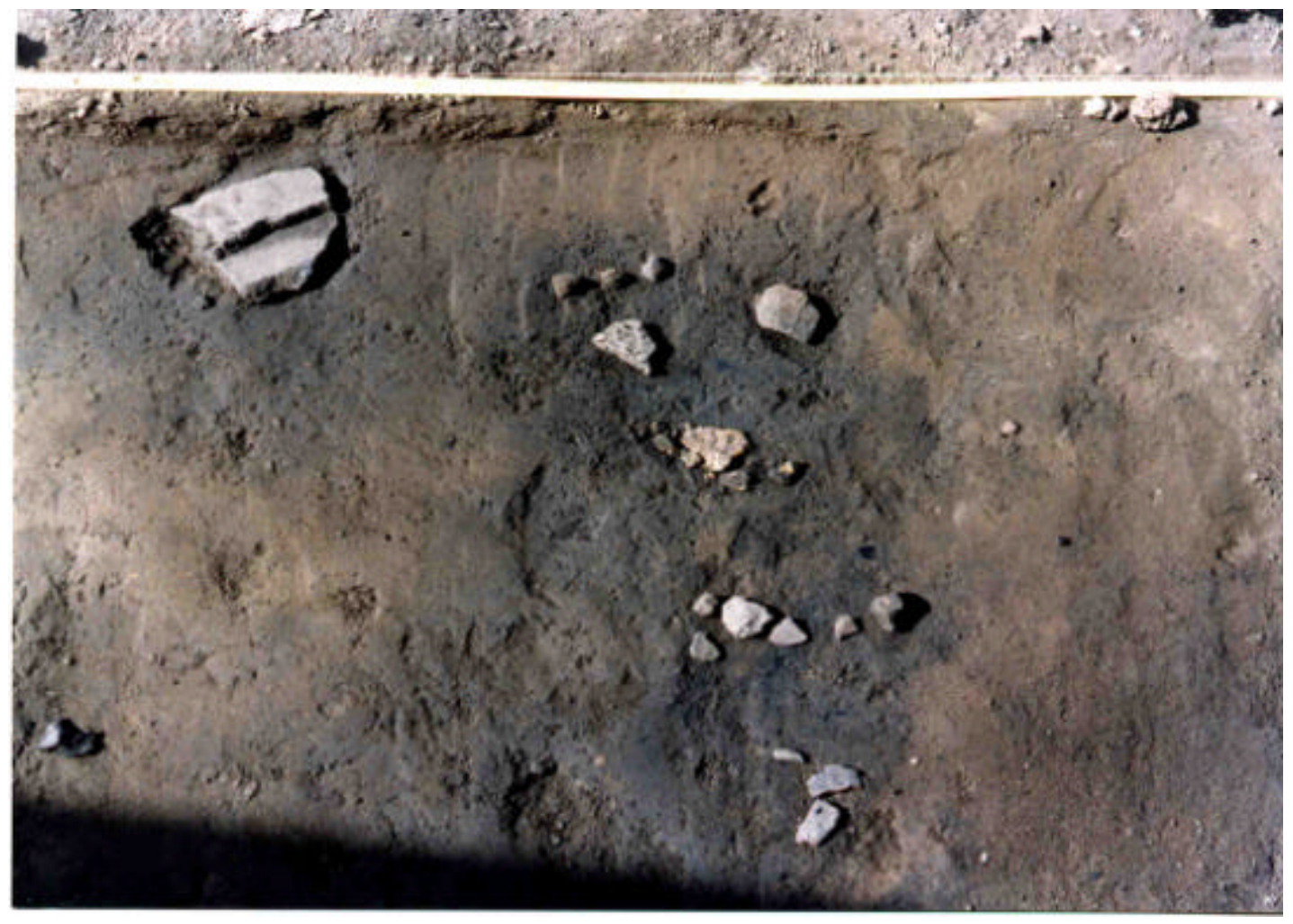

Foto 12 : Fogueira no setor 1 (foto Acervo LEPA/UFSM). 


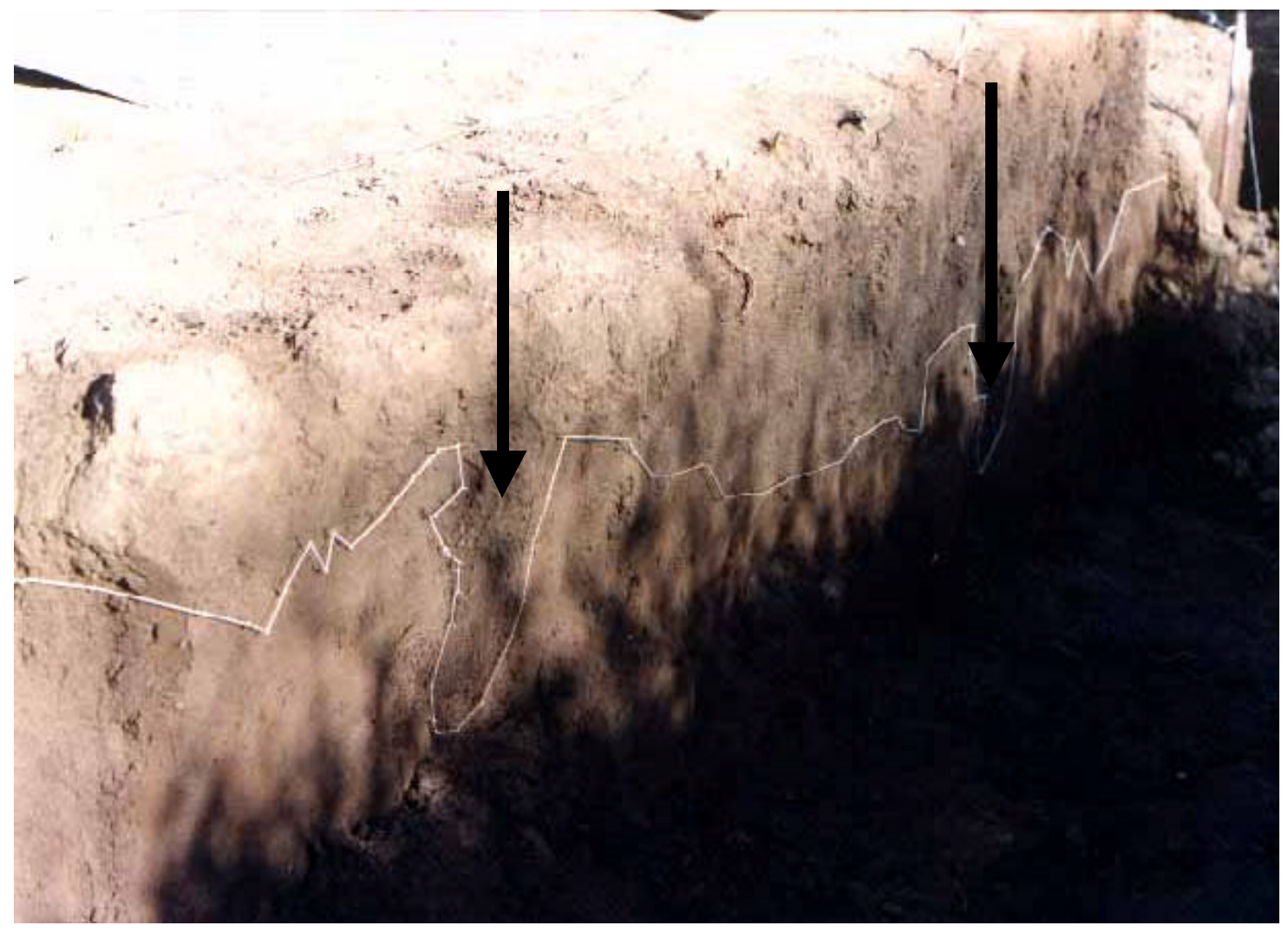

Foto 13 : Perfil da trincheira, próximo ao setor 1. Nas setas, exemplos de argiloturbação (foto Acervo LEPA/UFSM, modificado pelo autor).

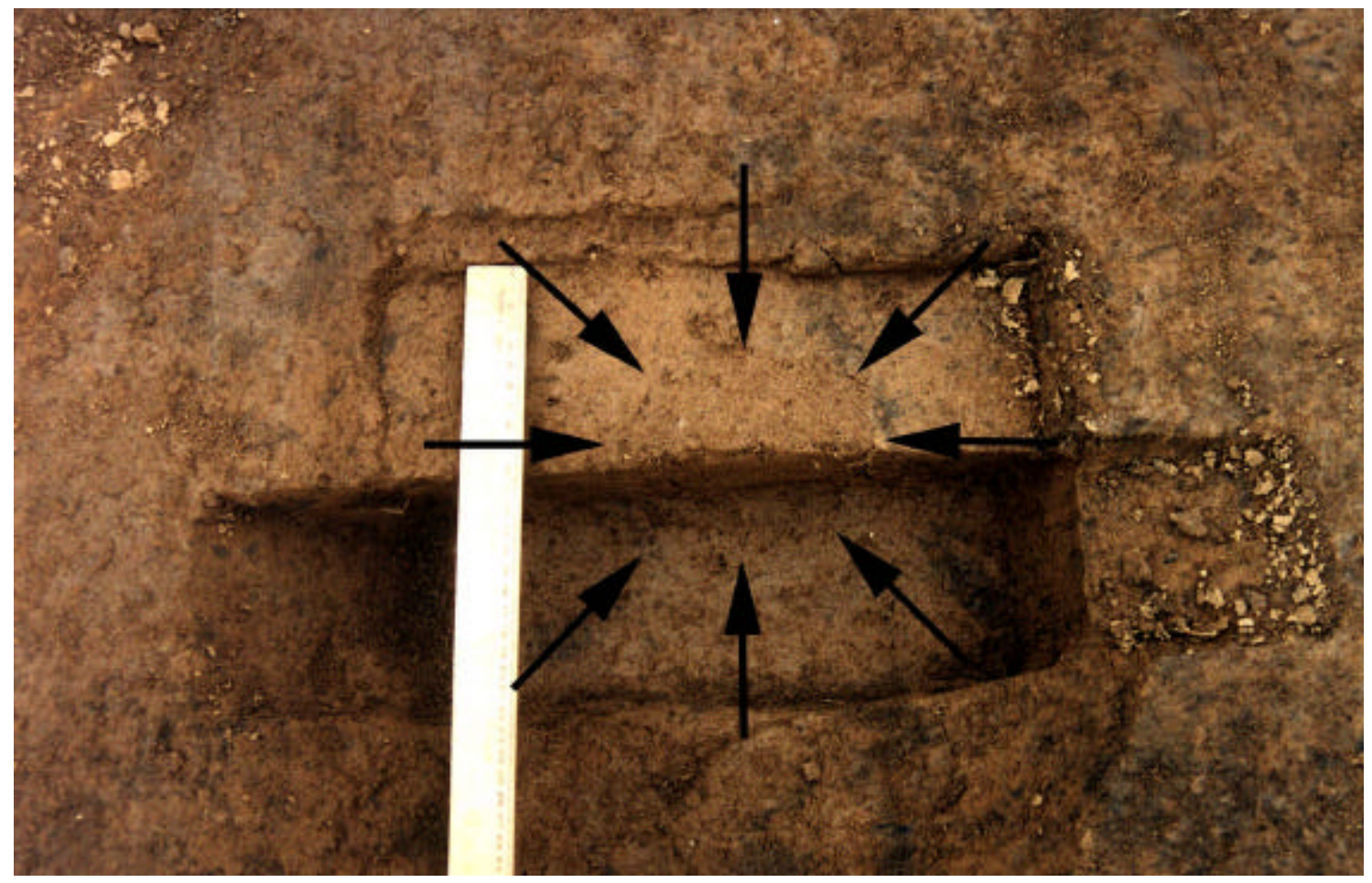

Foto 14: Negativo de esteio escavado no setor 1 (foto Acervo LEPA/UFSM, modificado pelo autor). 


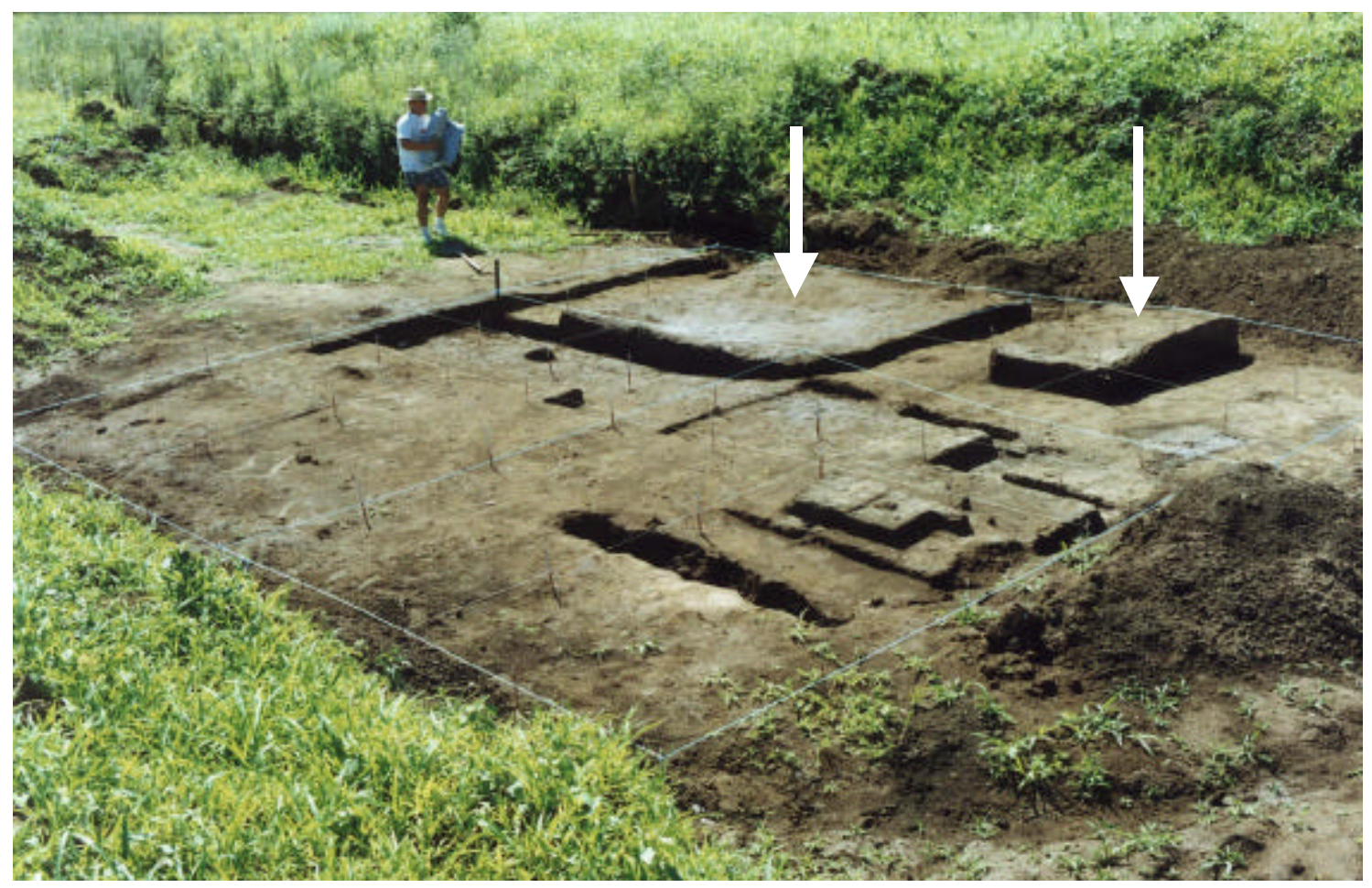

Foto 15: vista do final da escavação nos setores III, IV, V e VI. Nas setas, blocos testemunhos que não foram escavados. Flecha da esquerda, setor VI, da direita, setor V (Foto Sérgio Klamt).

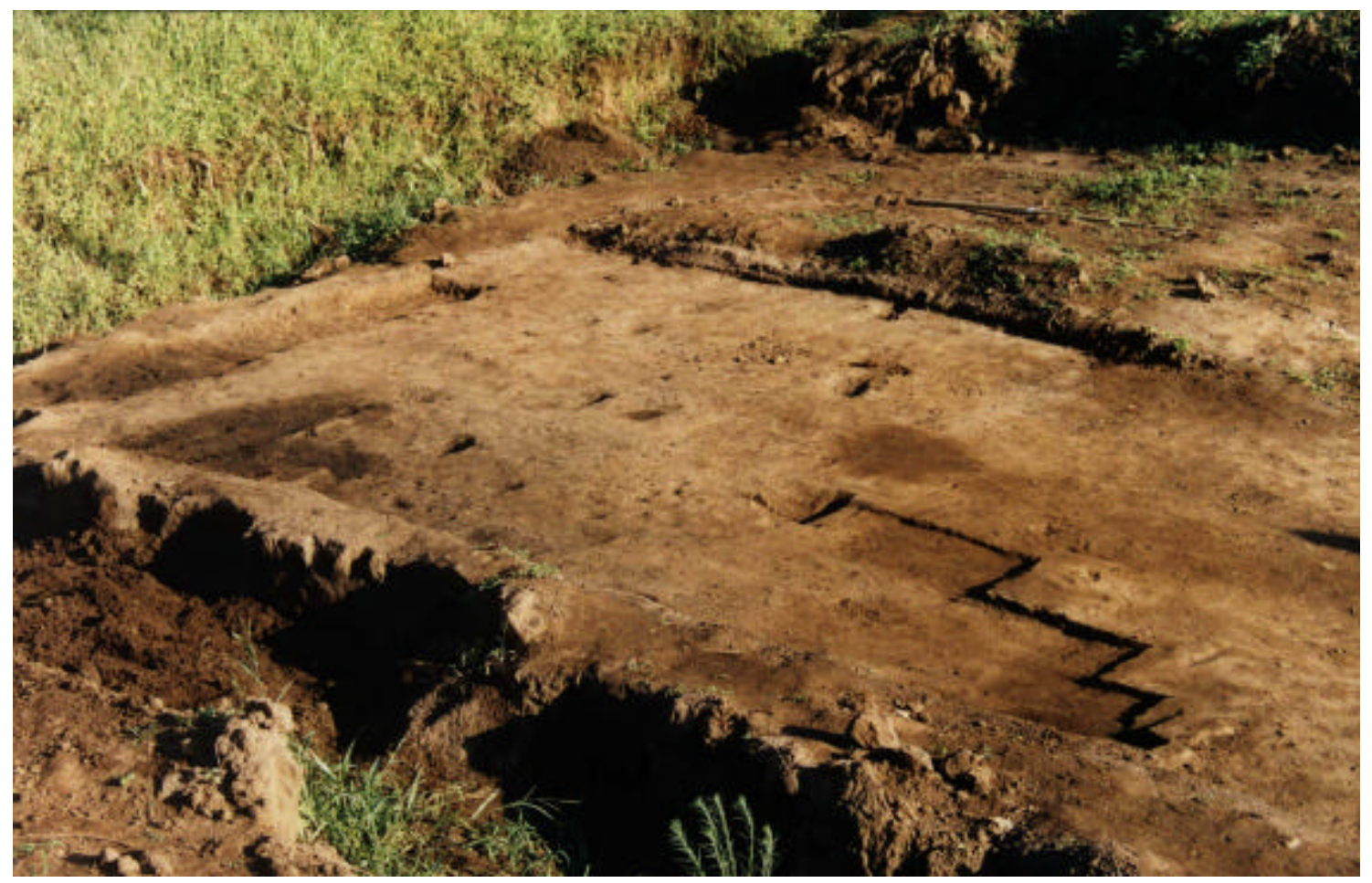

Foto 16: Vista do final da escavação no setor I (foto Acervo LEPA/UFSM). 
ANEXO 3

FOTOS DOS

ARTEFATOS 


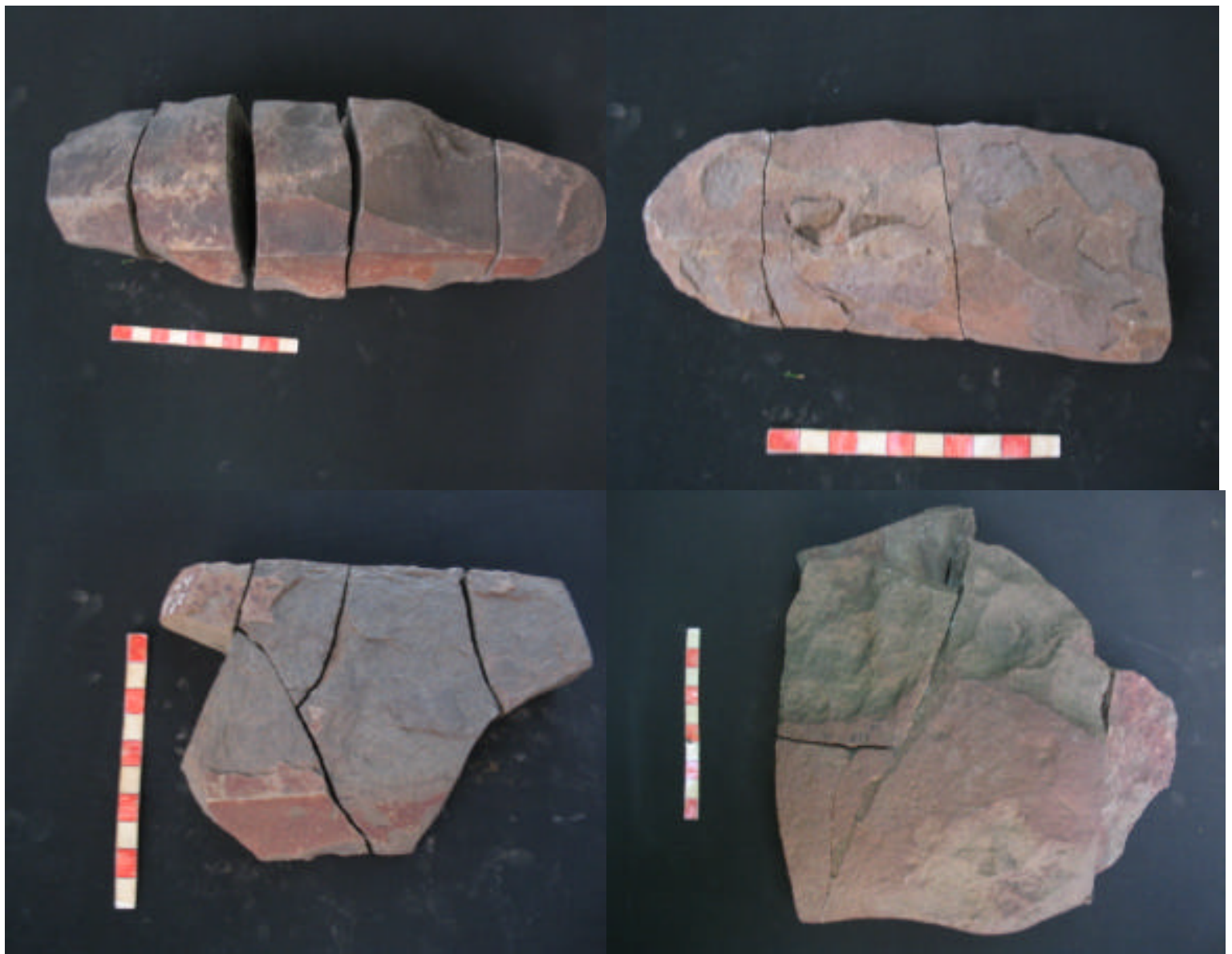

Foto 1: Testemunhos modificados (termóforas). Escala em centímetros (fotos: Sérgio Klamt). 


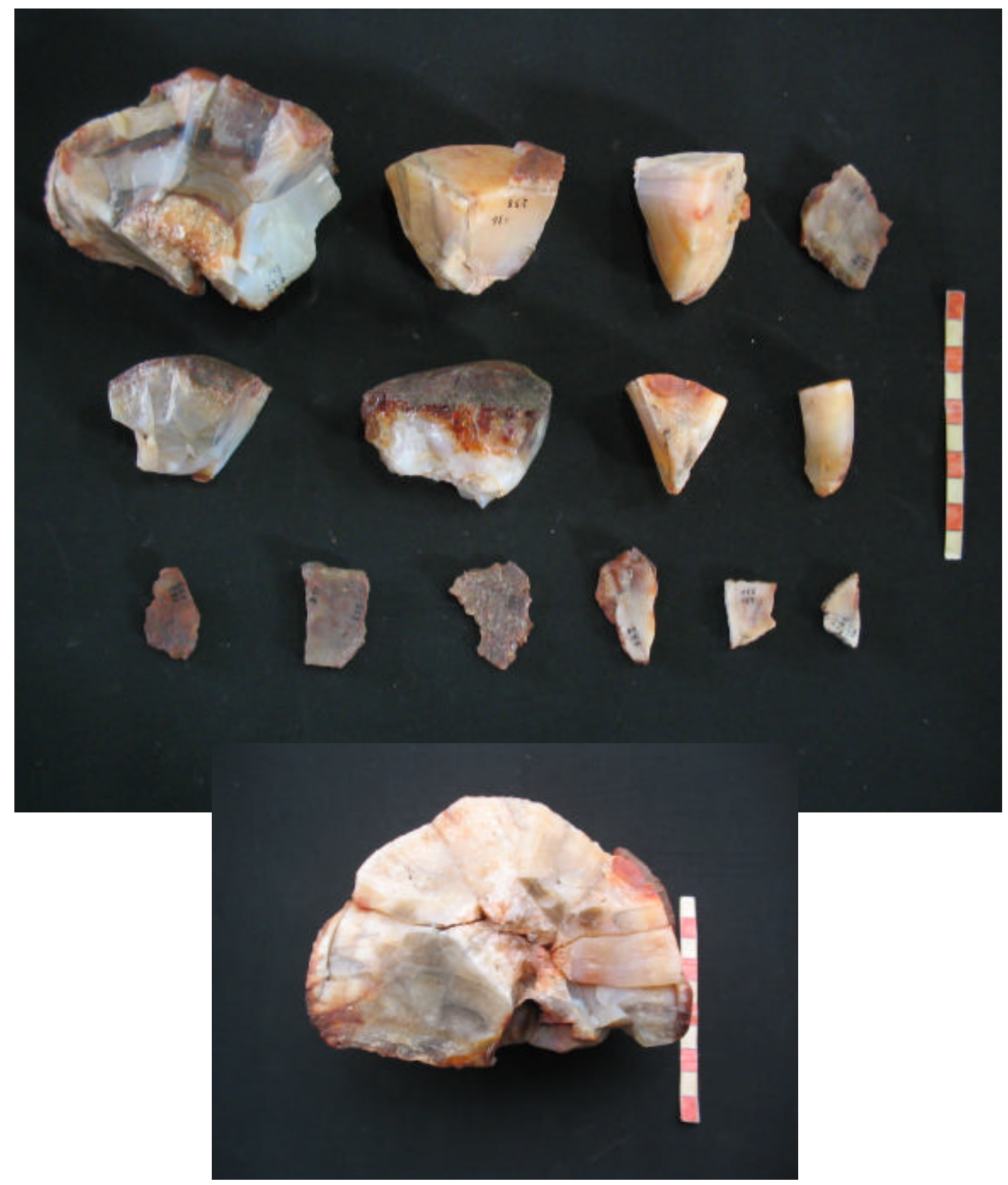

Foto 2 : Núcleo 3, conforme encontrado no sítio (acima) e remontado (abaixo)(fotos: Sérgio Klamt). 


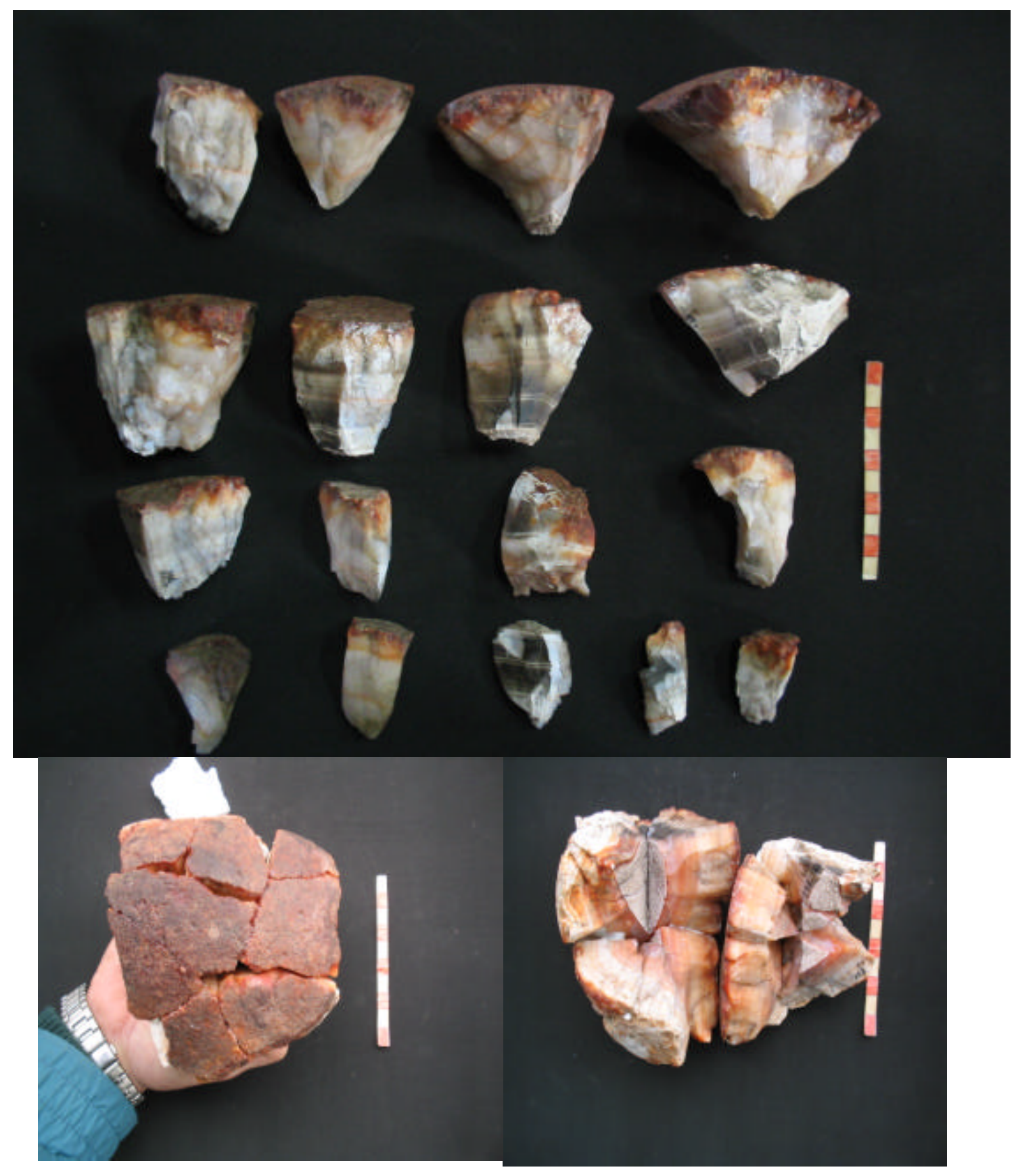

Foto 3 : Núcleo 4. Conforme encontrado no sítio (em cima), córtex remontado (embaixo, à esquerda) e ventral (embaixo, à direita). Observar os pontos de percussão na foto embaixo, à esquerda (fotos: Sérgio Klamt). 


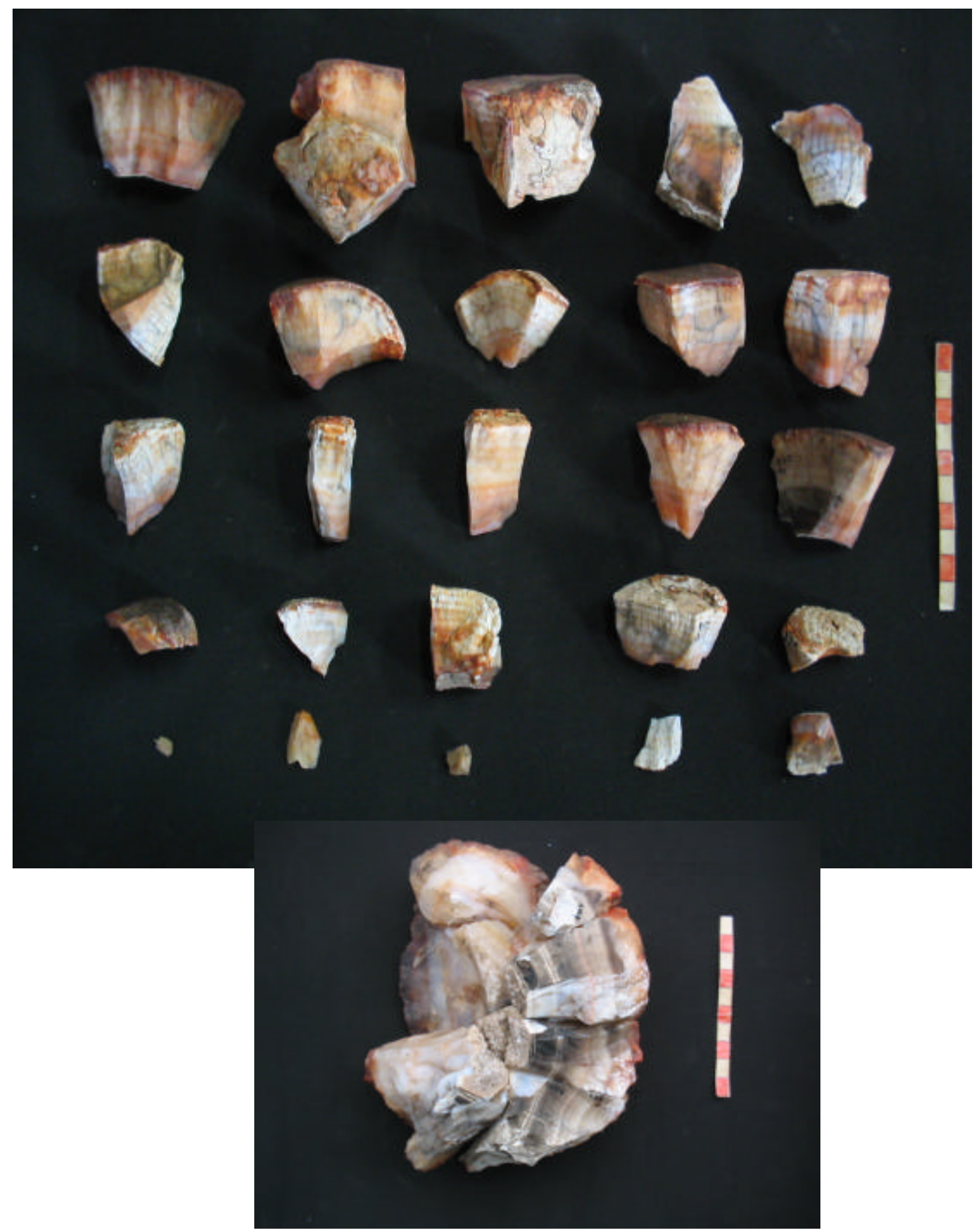

Foto 4 : Núcleo 5. Conforme encontrado no sítio ( em cima), e remontado (abaixo) (fotos: Sérgio Klamt). 


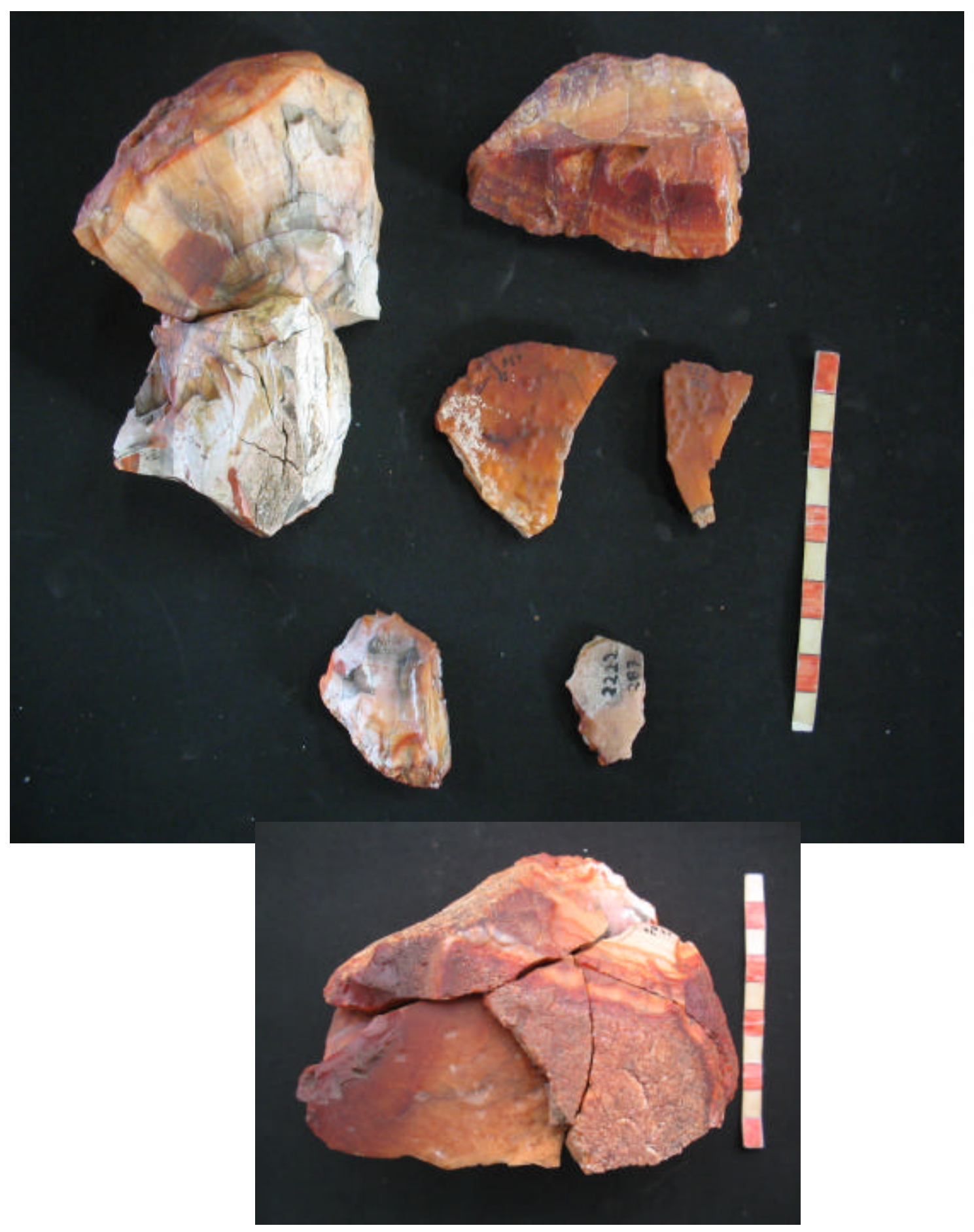

Foto 5 : Núcleo 6. Conforme encontrado no sítio (em cima) e remontado (abaixo).(fotos: Sérgio Klamt). 


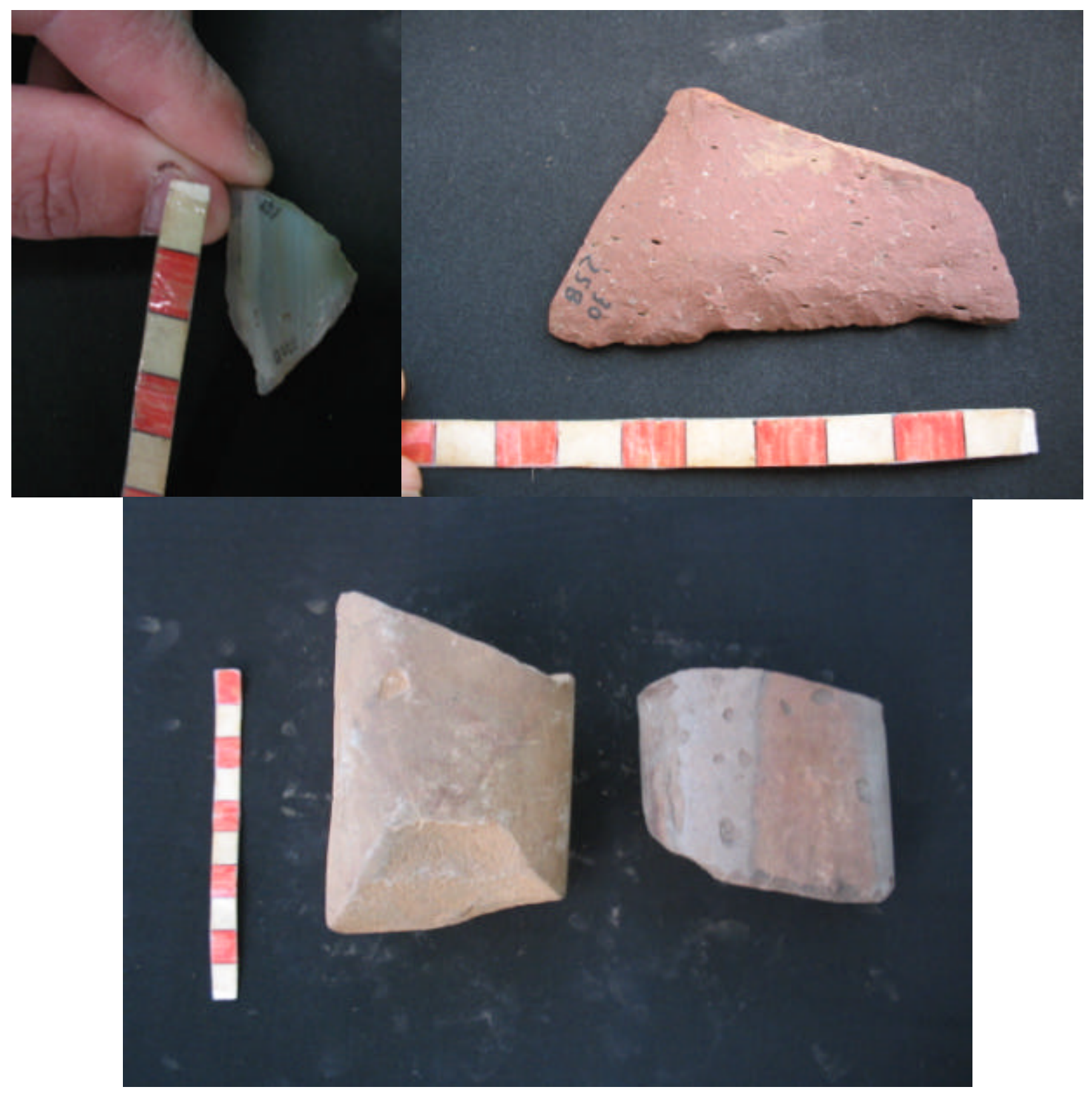

Foto 6 : Lascas retocadas. À esquerda, lasca de calcedônia. À direita, lasca de riolito. Abaixo, fragmentos de peças polidas (fotos: Sérgio Klamt.) 


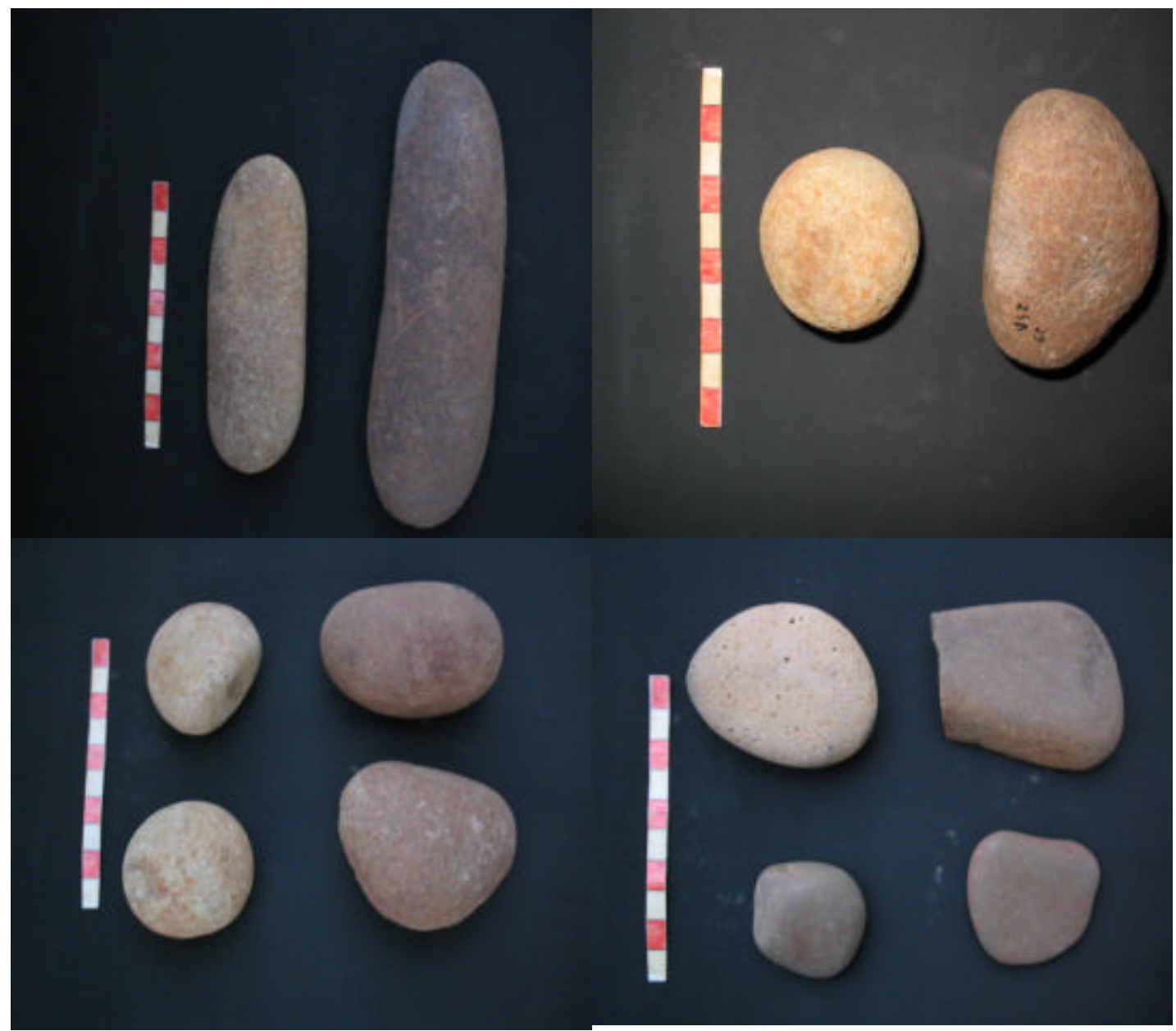

Foto 7: "Polidores" em basalto encontrados no sítio. À título de comparação, à esquerda de cada foto são apresentados os seixos naturais, recolhidos em cascalheiras de rio. À direita, material encontrado na escavação (fotos: Sérgio Klamt). 


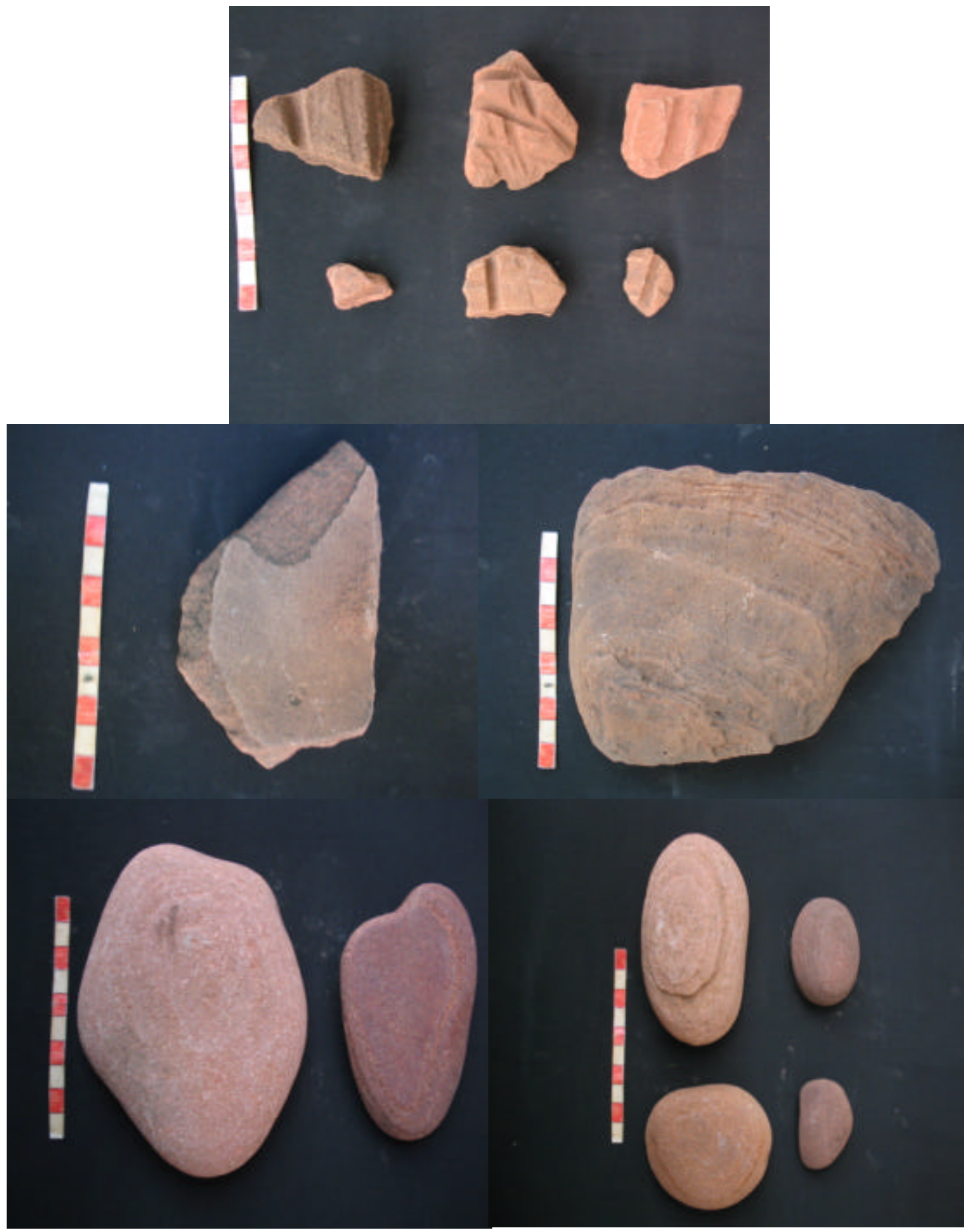

Foto 8: Artefatos em arenito. No topo, Afiadores em canaleta. No centro, peças com sinal de polimento.Em baixo, os "polidores" em seixo de arenito encontrados no sítio. À título de comparação, à esquerda de cada foto são apresentados os seixos naturais, recolhidos em cascalheiras de rio. À direita, material encontrado na escavação (fotos: Sérgio Klamt). 


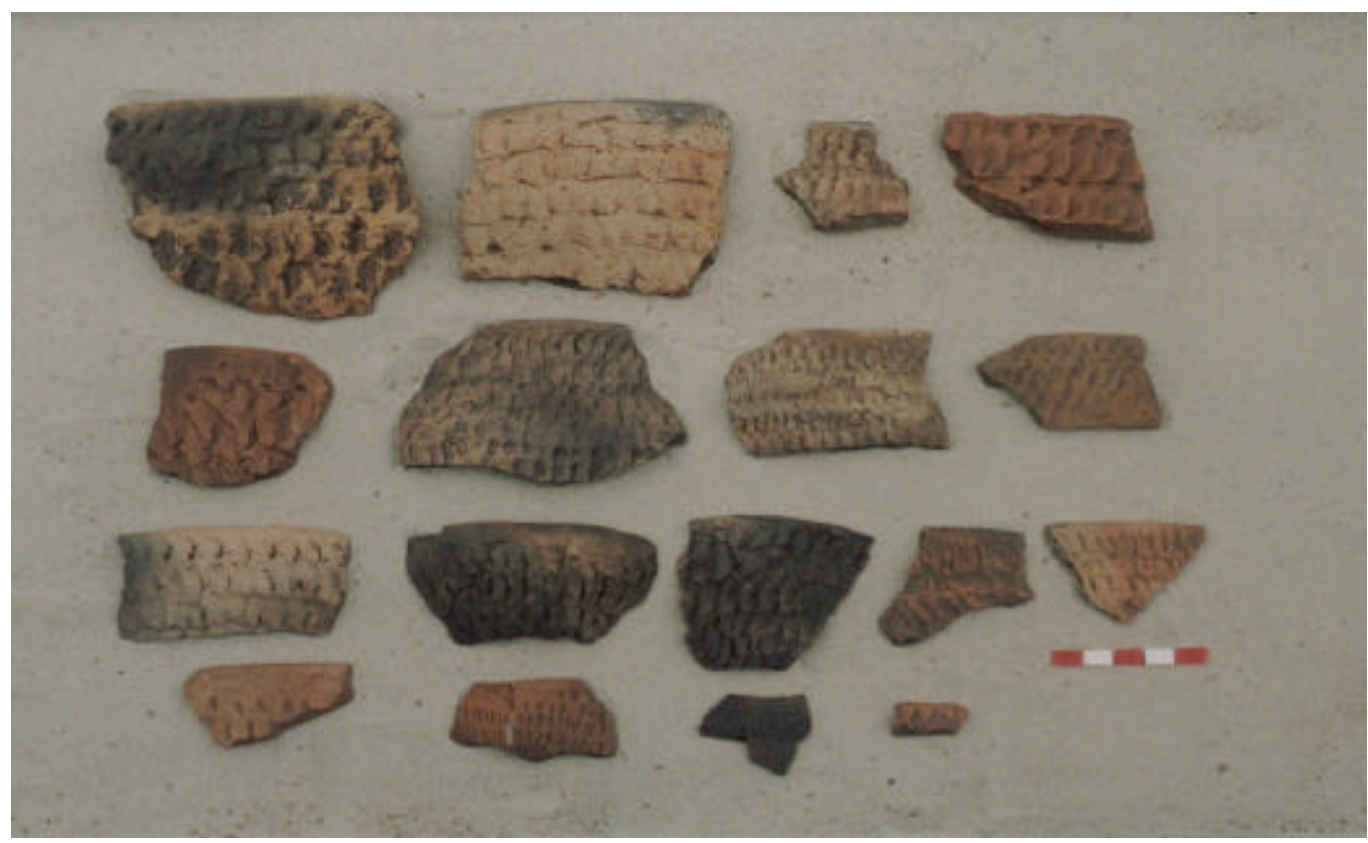

Foto 9: Acima, tipos de tratamento de superfície e decoração. Acima, $1^{\mathrm{a}}$ e $2^{\mathrm{a}}$ linhas, tipo corrugado; $3^{\mathrm{a}}$ linha, corrugado-ungulado; $4^{\mathrm{a}}$ linha, ungulado (fotos: Sérgio Klamt).

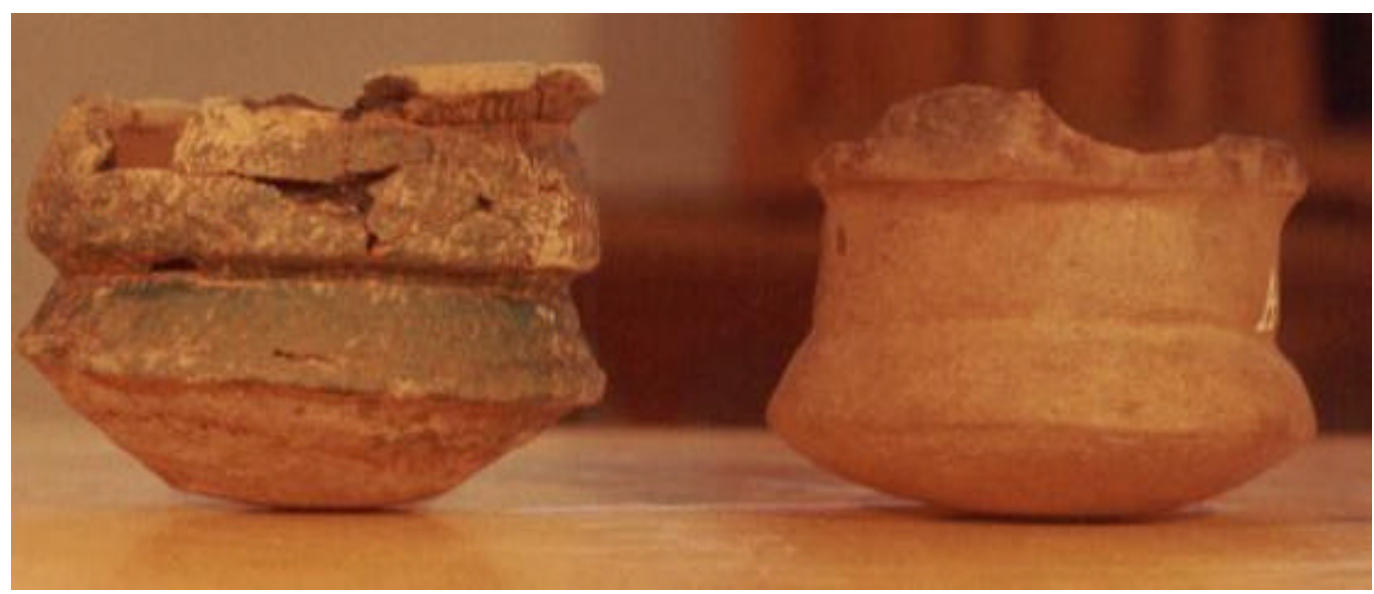

Foto 10: Vasilhas com formas 'exóticas' depositadas no Museu Antropoló-gico Diretor Pestana, Ijuí, RS. Observar que o perfil das bordas deixariam margens para diversas reconstruções diferentes das formas inteiras (foto: André Soares). 


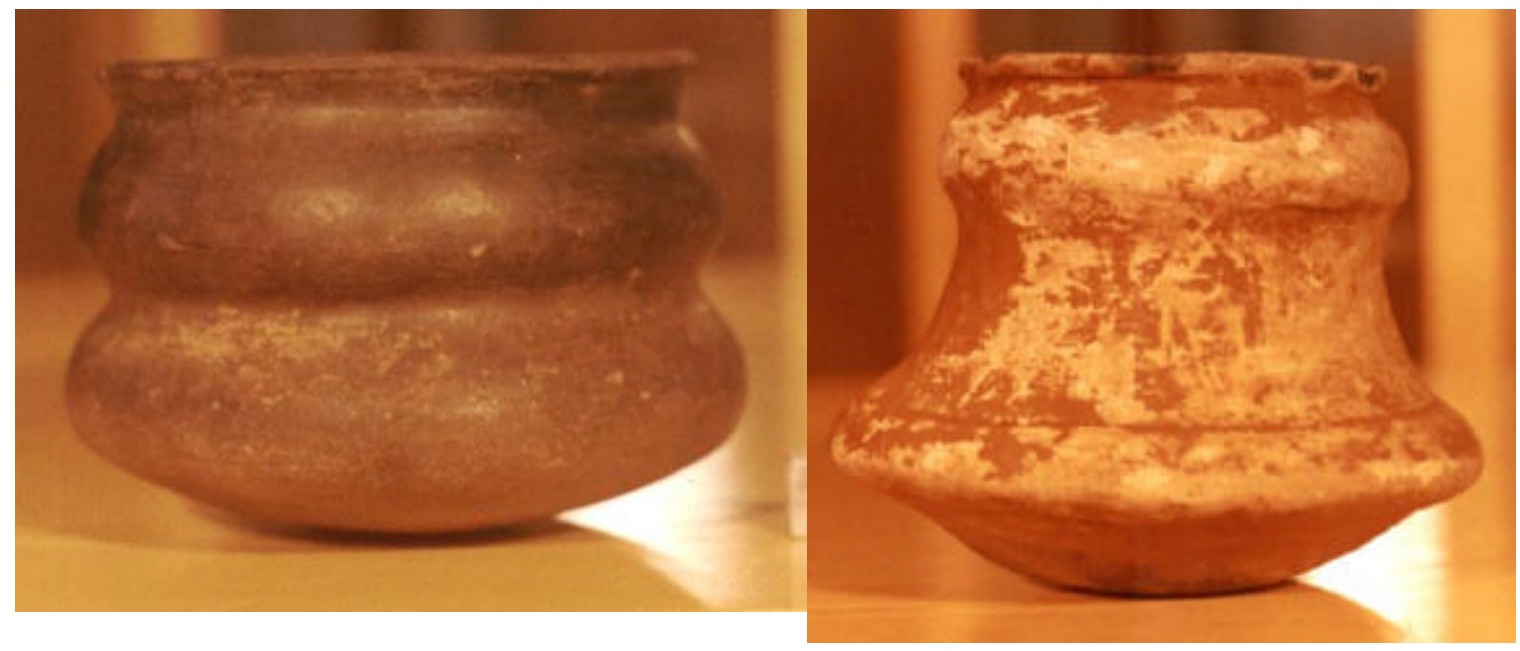

Foto 11: Vasilhas depositadas no Museu Antropológico Diretor Pestana. Também foram encontradas vasilhas 'exóticas' nos tratamentos de superfície corrugado e ungulado (foto: André Soares).

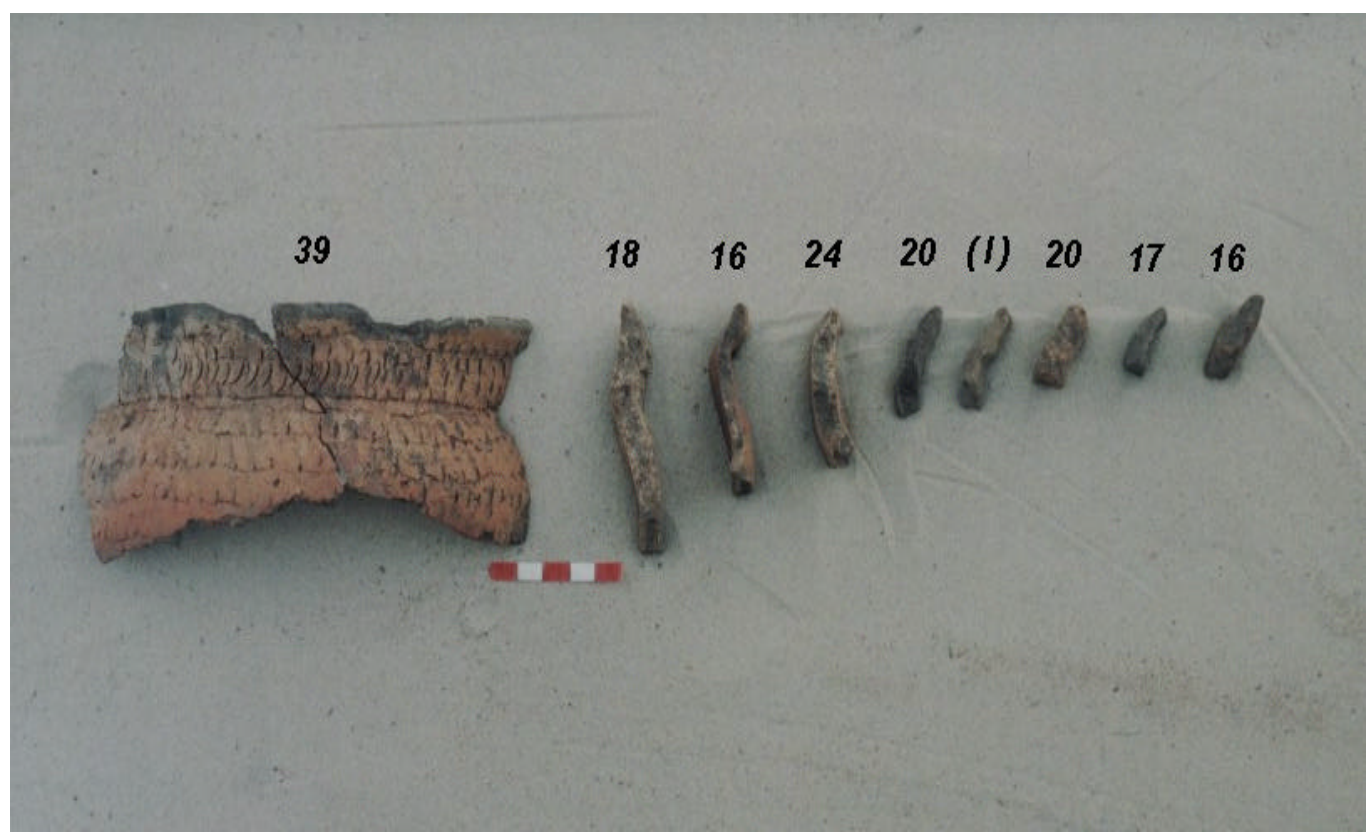

Foto 12: Bordas de panelas corrugadas e corrugado-ungulado. Sobre cada borda é colocado o valor do diâmetro de boca. O símbolo (I) significa diâmetro ignorado (impossível reconstituição) (foto: Sérgio Klamt). 


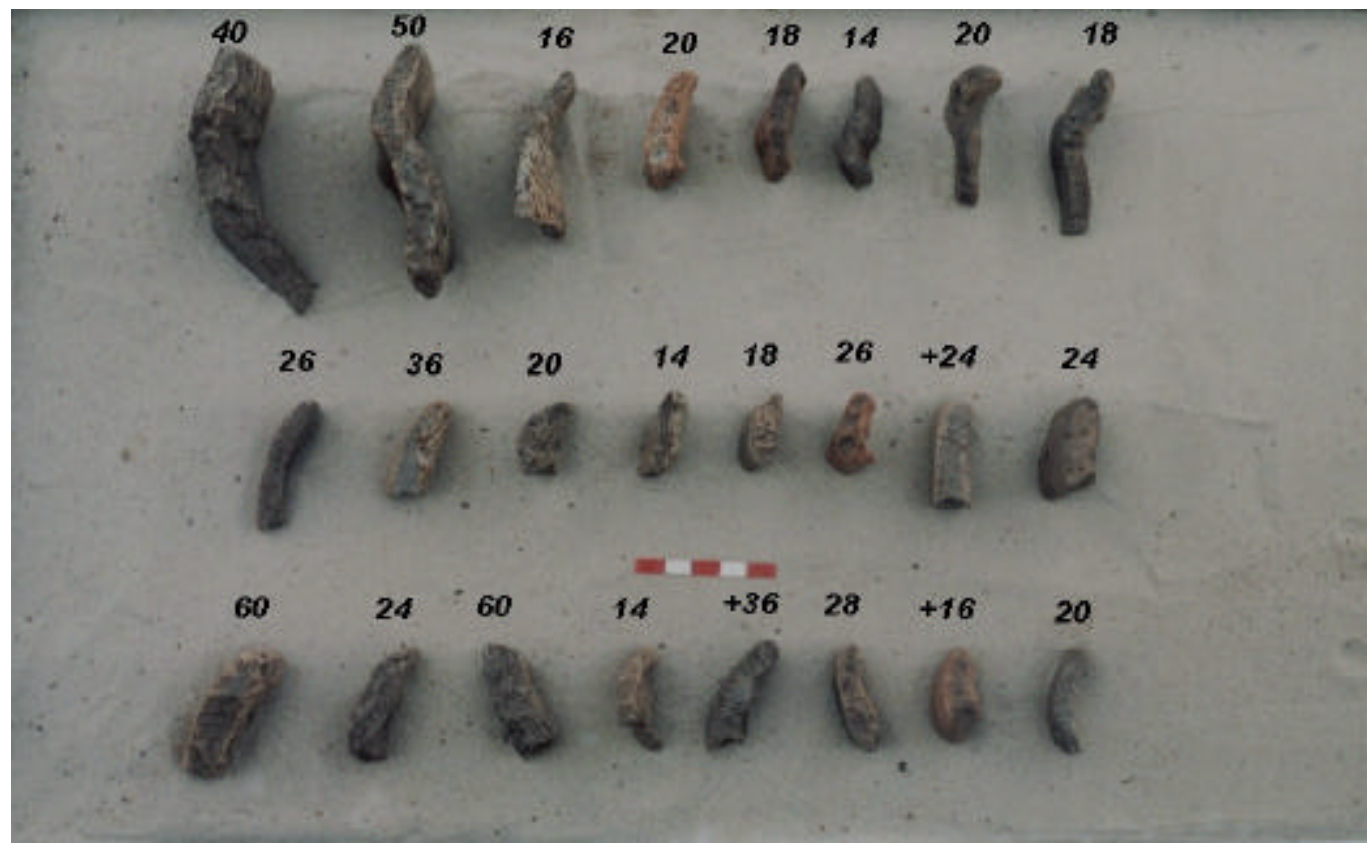

Foto 13: Bordas de panelas corrugadas e corrugado-ungulado (foto: Sérgio Klamt).

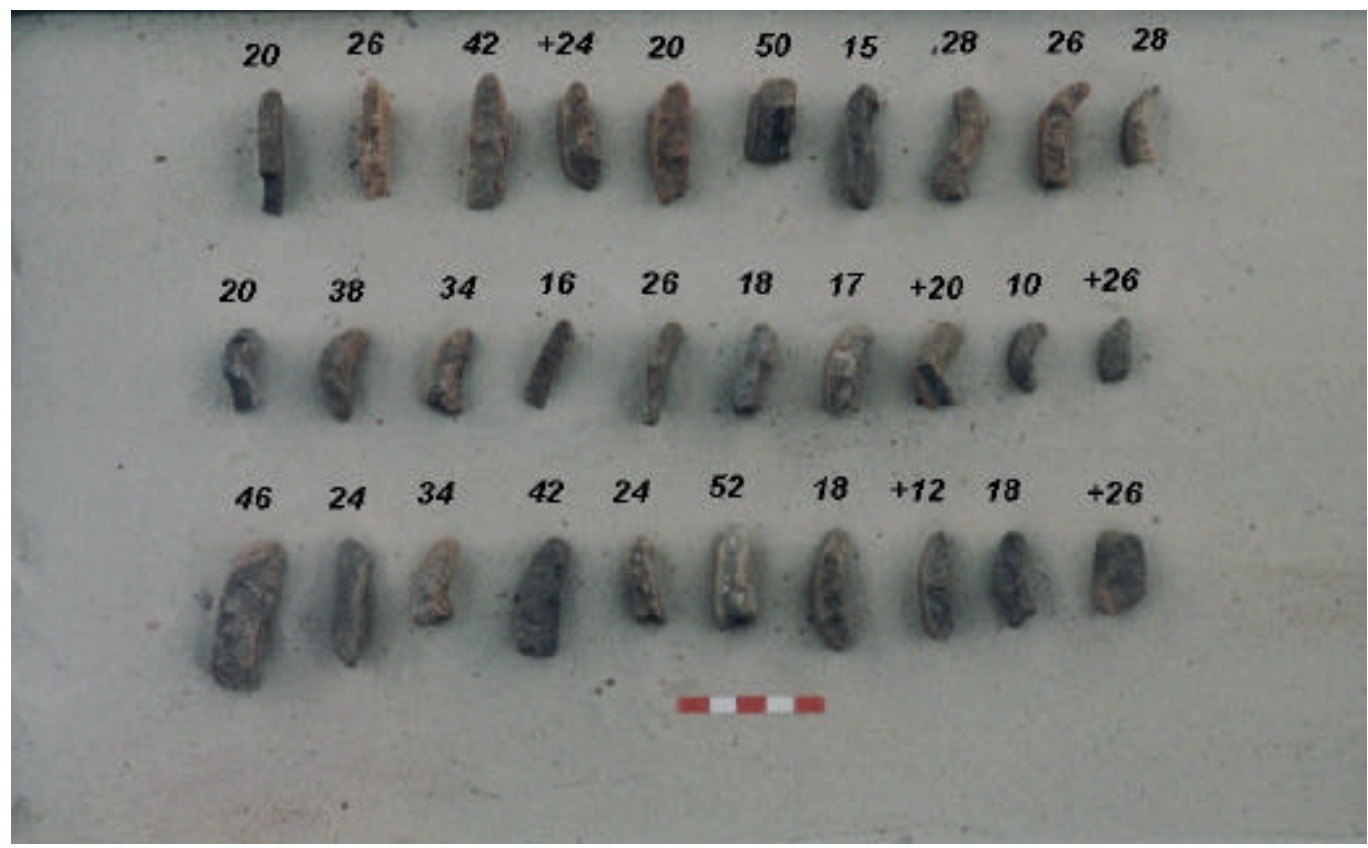

Foto 14: Bordas de panelas corrugadas e corrugado-ungulado (foto: Sérgio Klamt). 


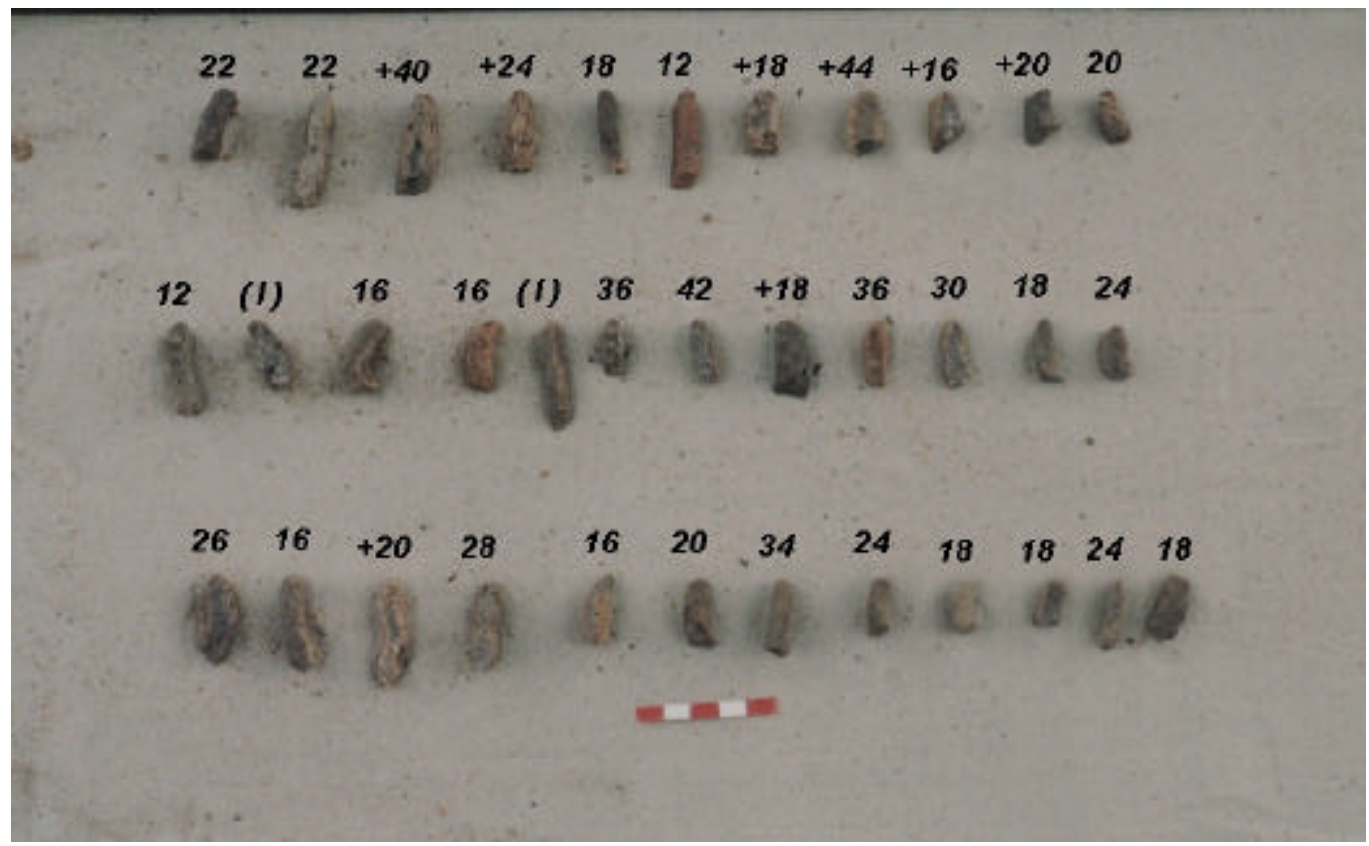

Foto 15: Bordas de panelas corrugadas e corrugado-ungulado(foto: Sérgio Klamt).

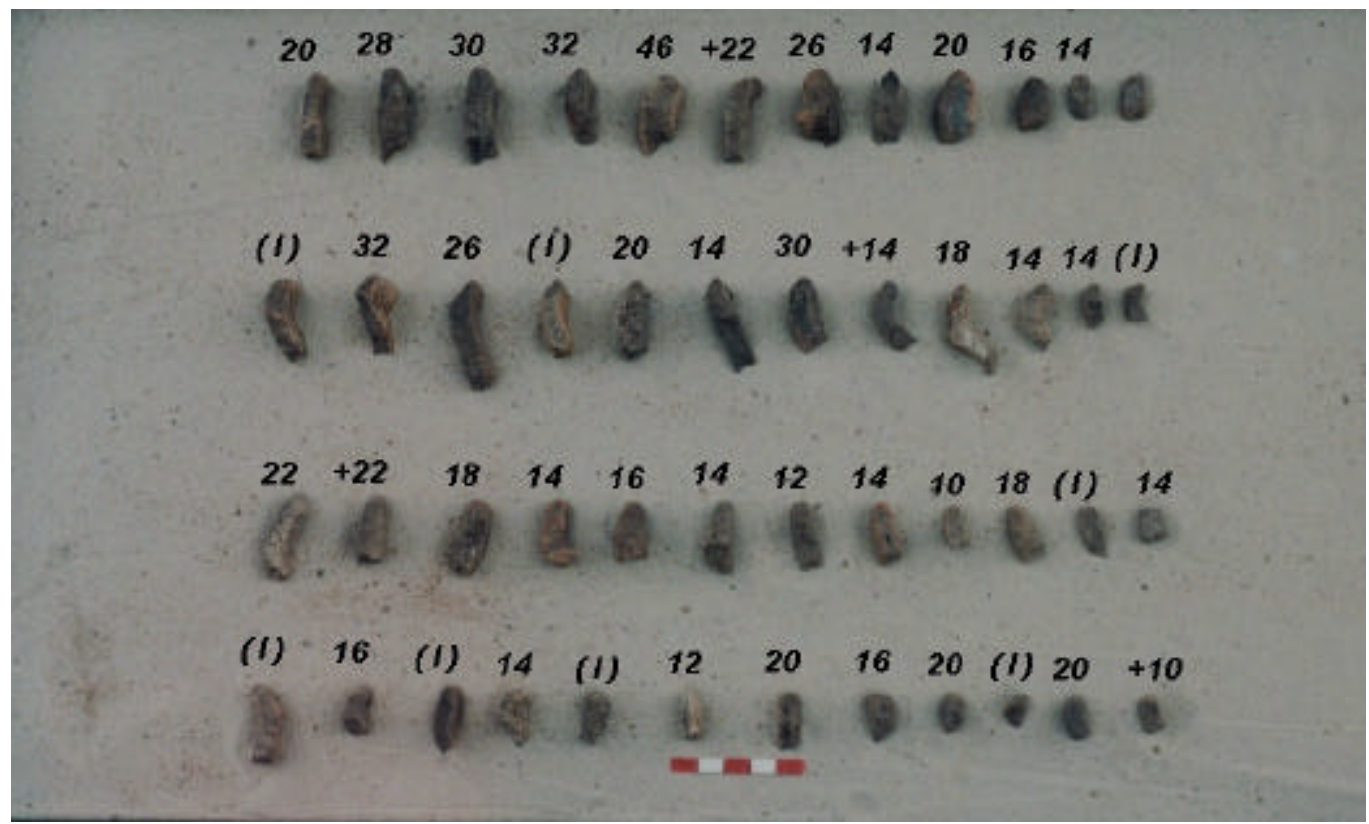

Foto 16: Bordas de panelas corrugadas e corrugado-ungulado (foto: Sérgio Klamt). 


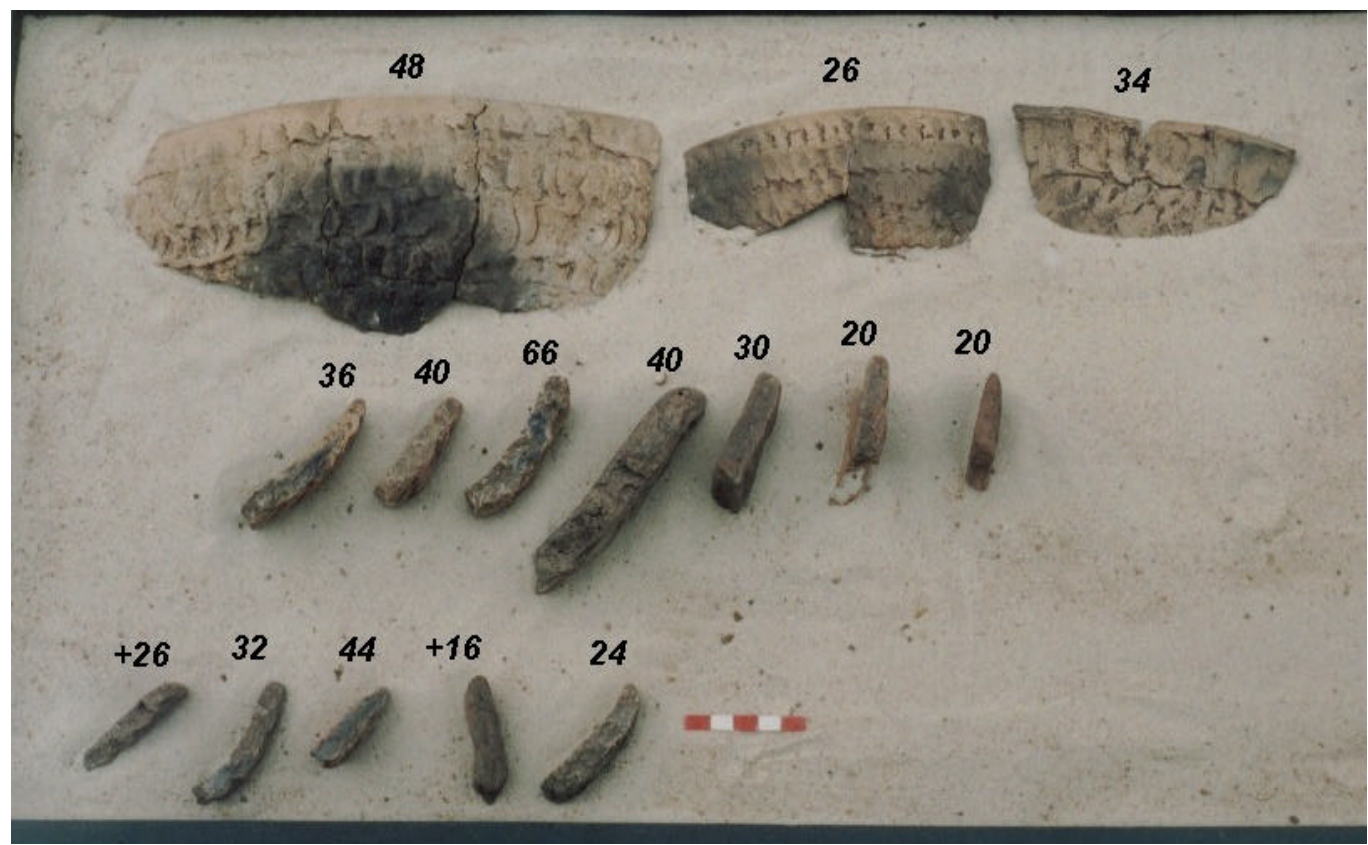

Foto 17: Bordas de tigelas corrugadas e corrugado-ungulado (foto: Sérgio Klamt).

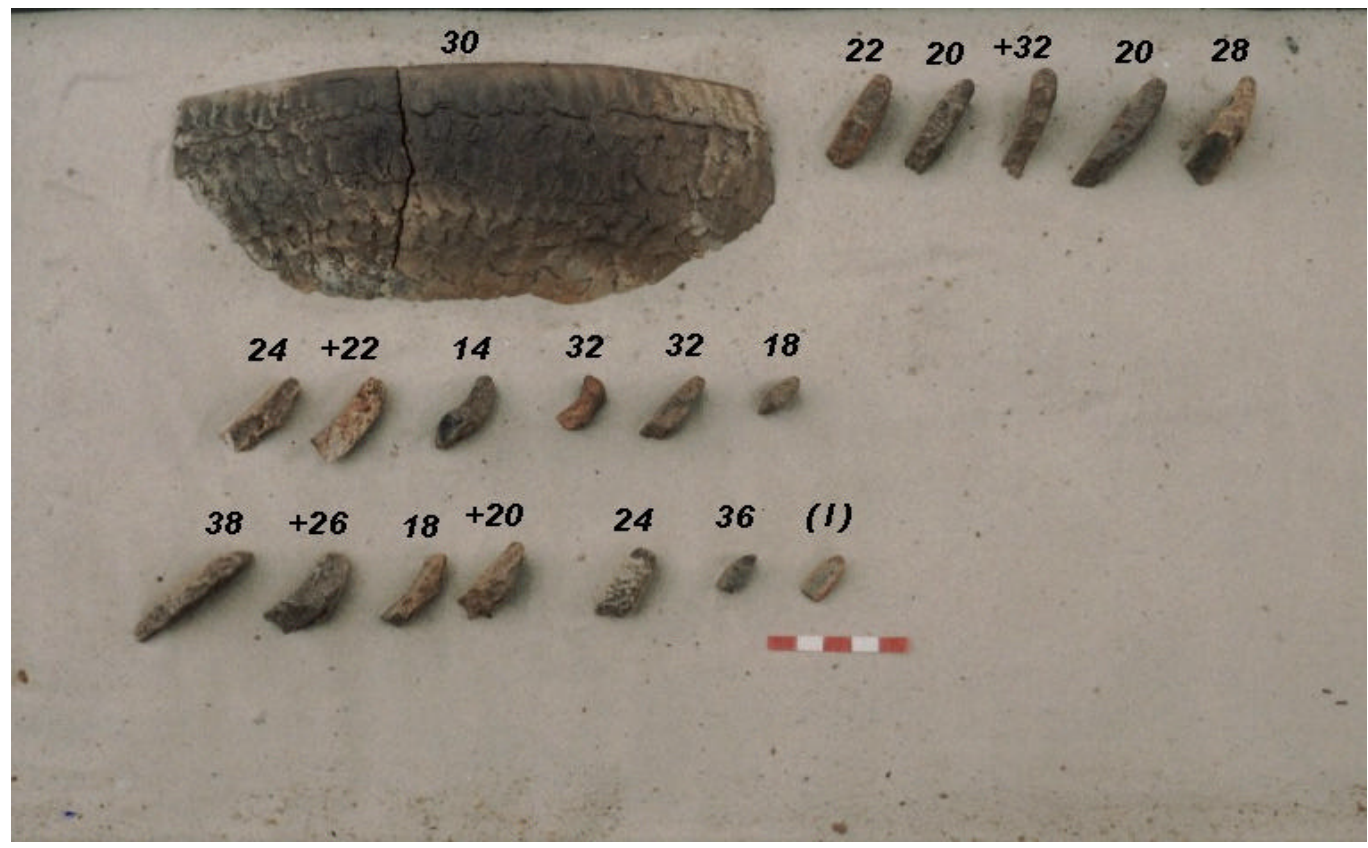

Foto 18: Bordas de tigelas corrugadas e corrugado-ungulado (foto: Sérgio Klamt). 


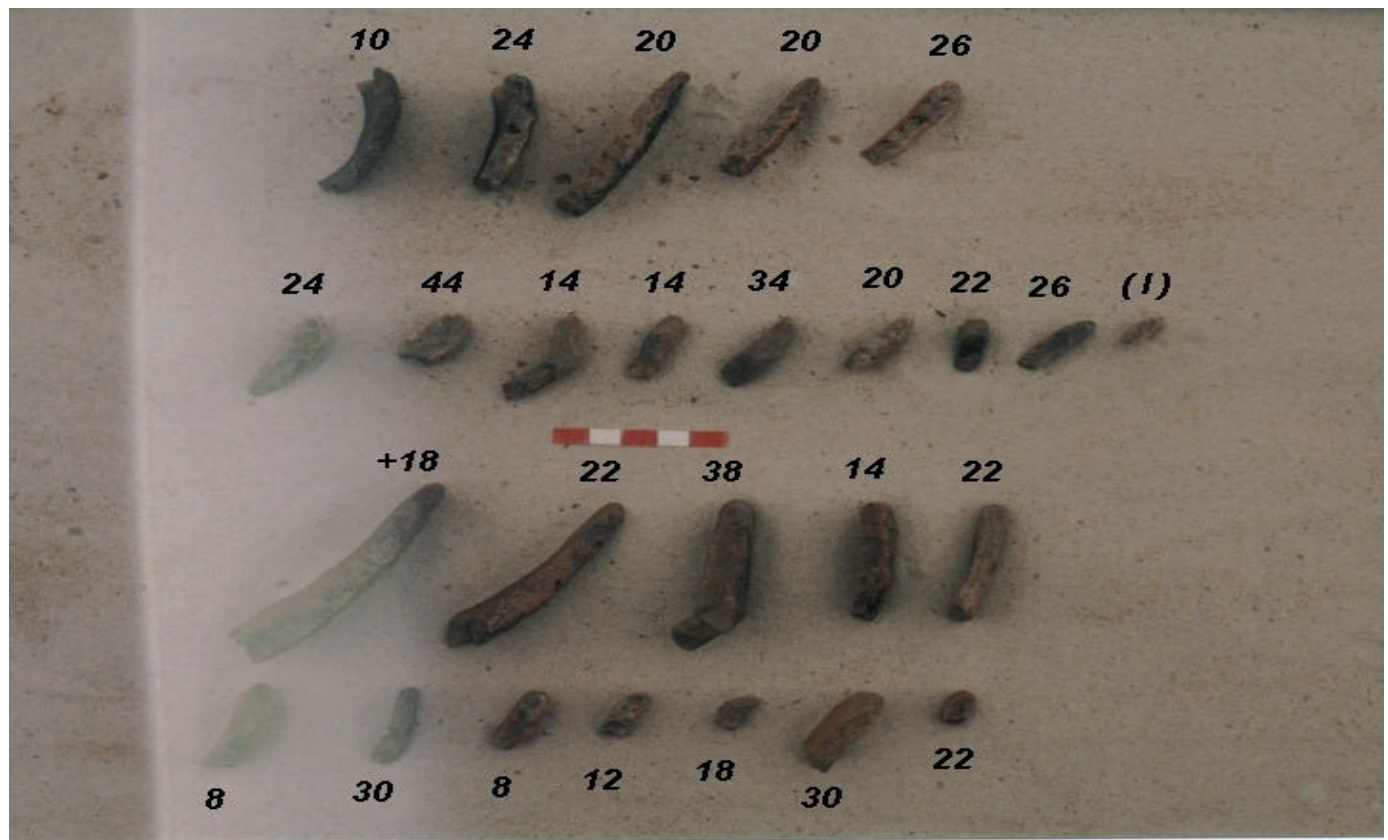

Foto 19: Bordas de tigelas corrugadas e corrugado-ungulado (foto: Sérgio Klamt).

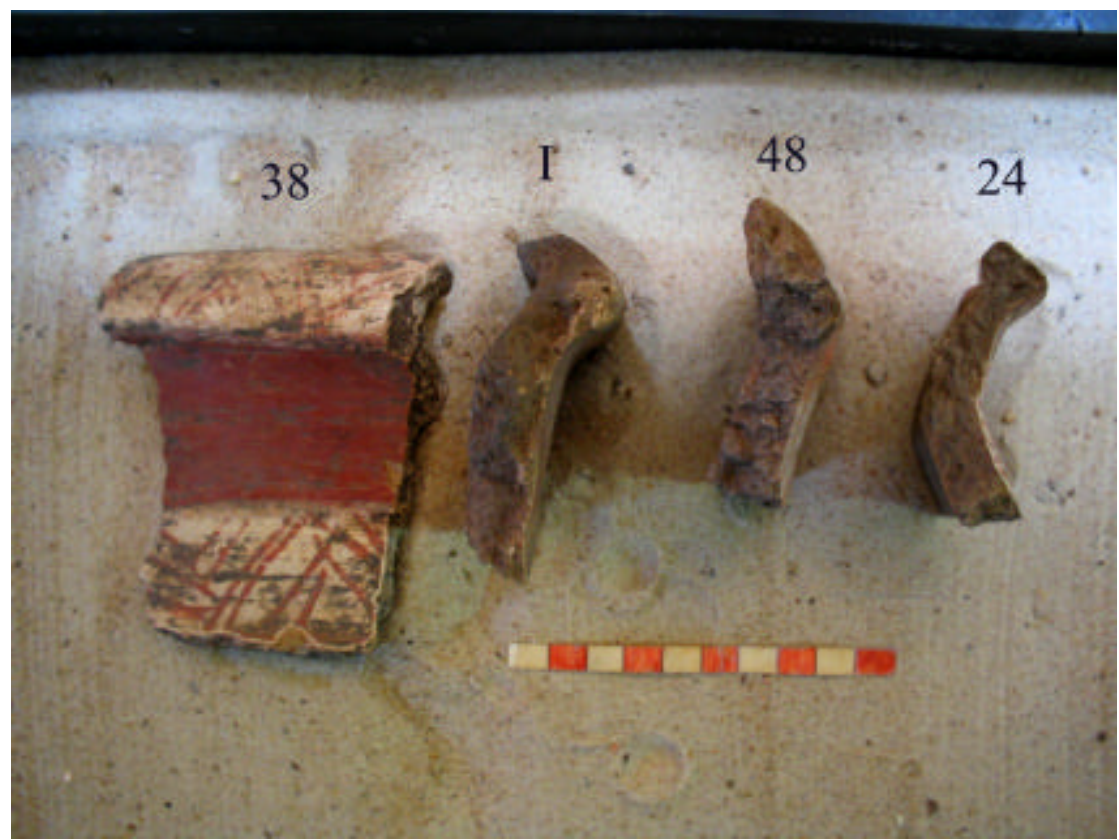

Foto 20: Bordas de talhas (foto: Sérgio Klamt). 


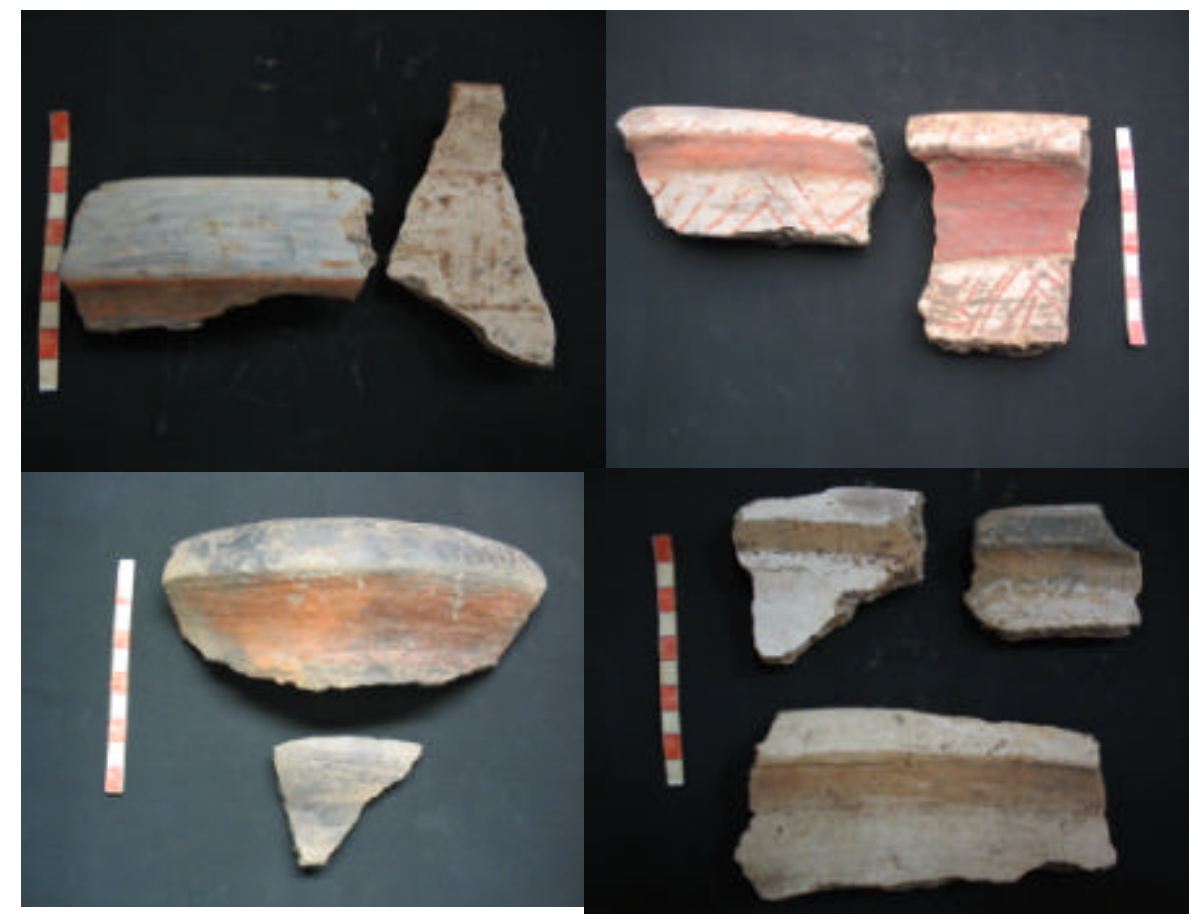

Foto 21: Motivo das pinturas externas existentes nas bordas das talhas (foto: Sérgio Klamt).

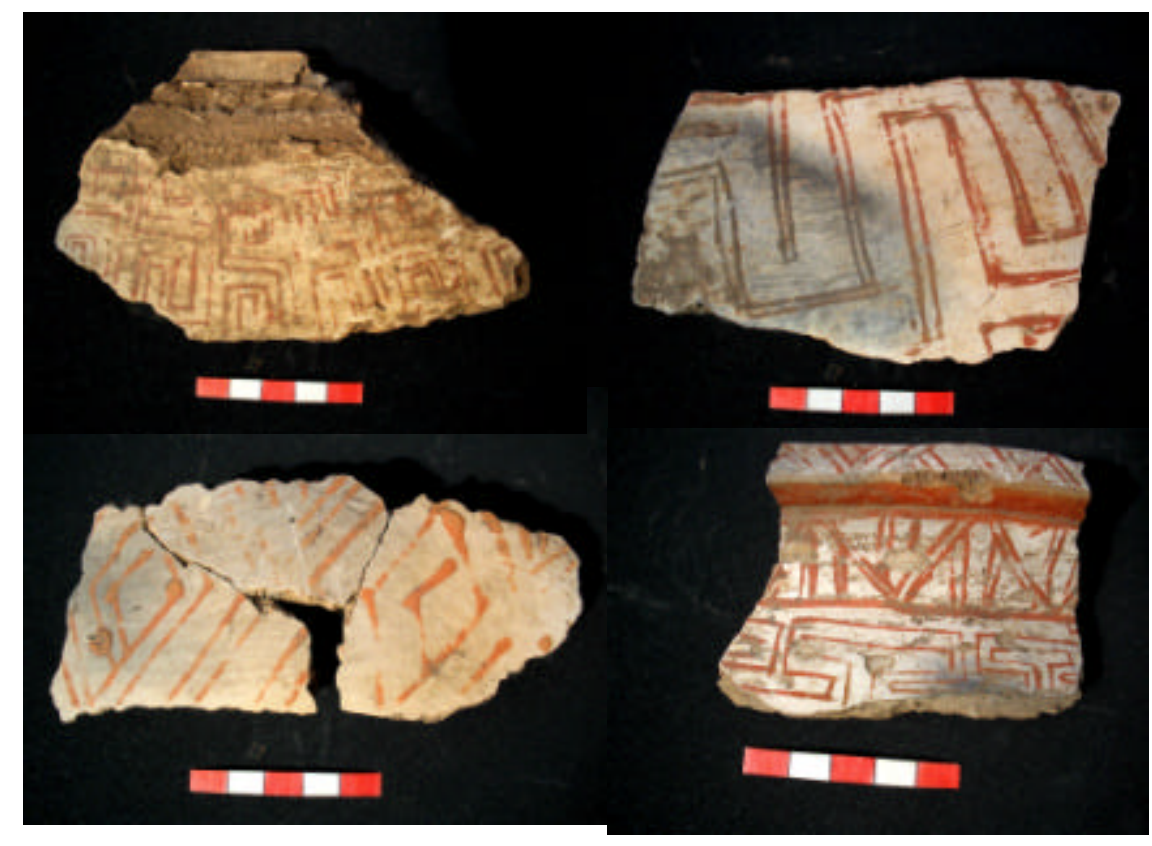

Foto 22: Motivos de pintura externo das talhas (fotos: Sérgio Klamt). 


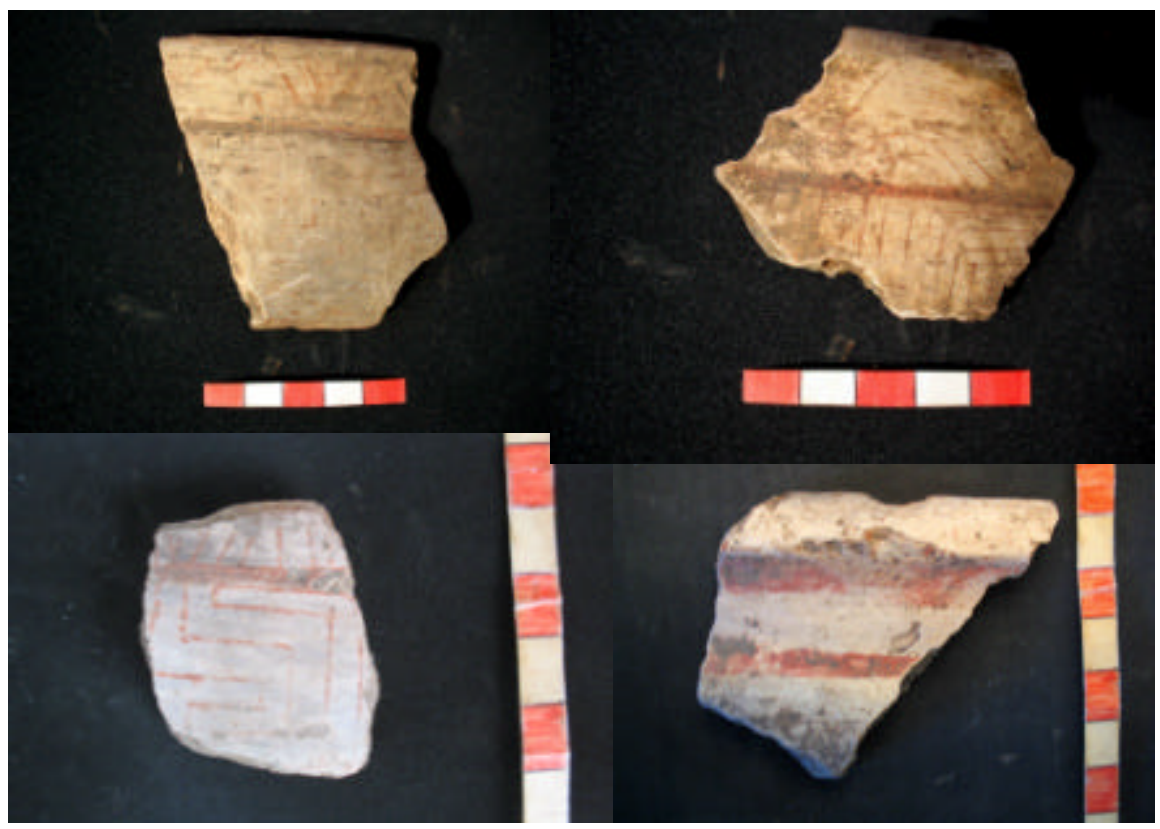

Foto 23: Motivo das pinturas externas existentes nas tigelas de beber carenadas (fotos: Sérgio Klamt).

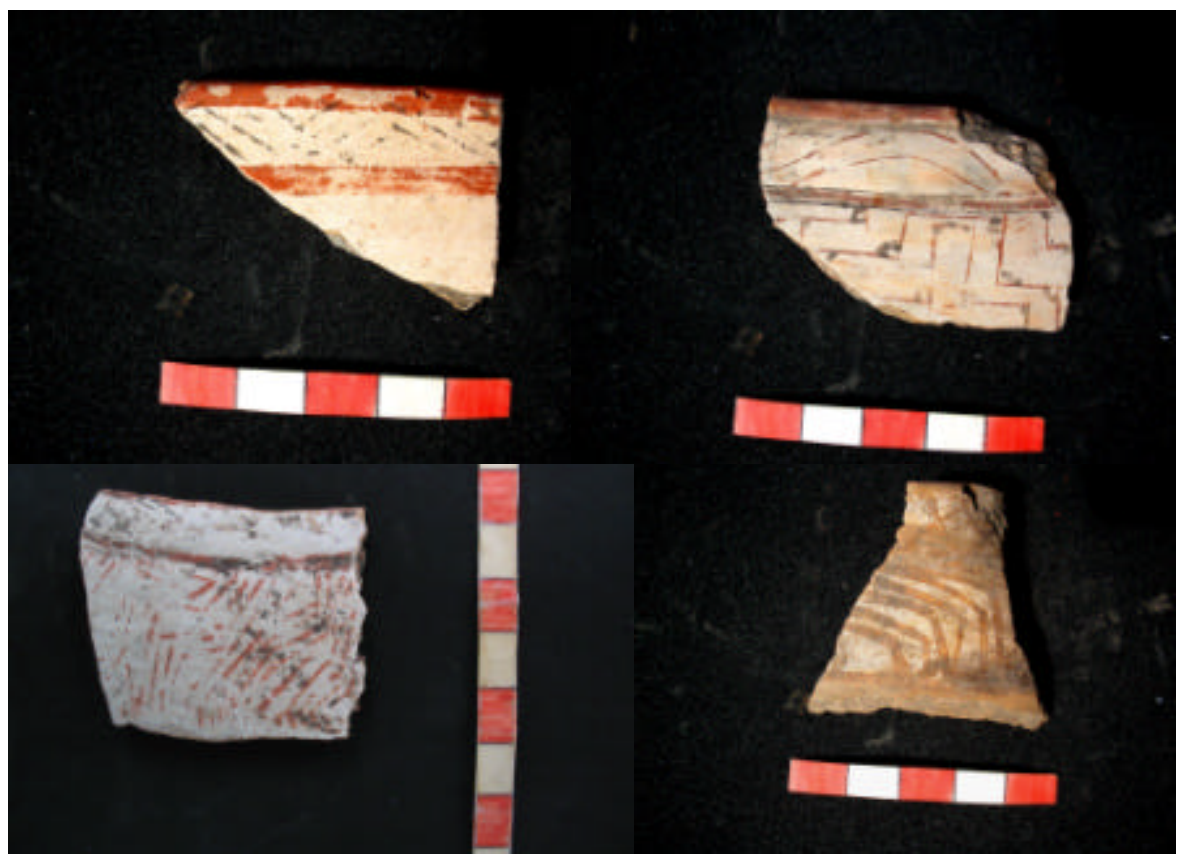

Foto 24 : Motivos de pintura externo das tigelas de beber carenadas. (fotos: Sérgio Klamt). 


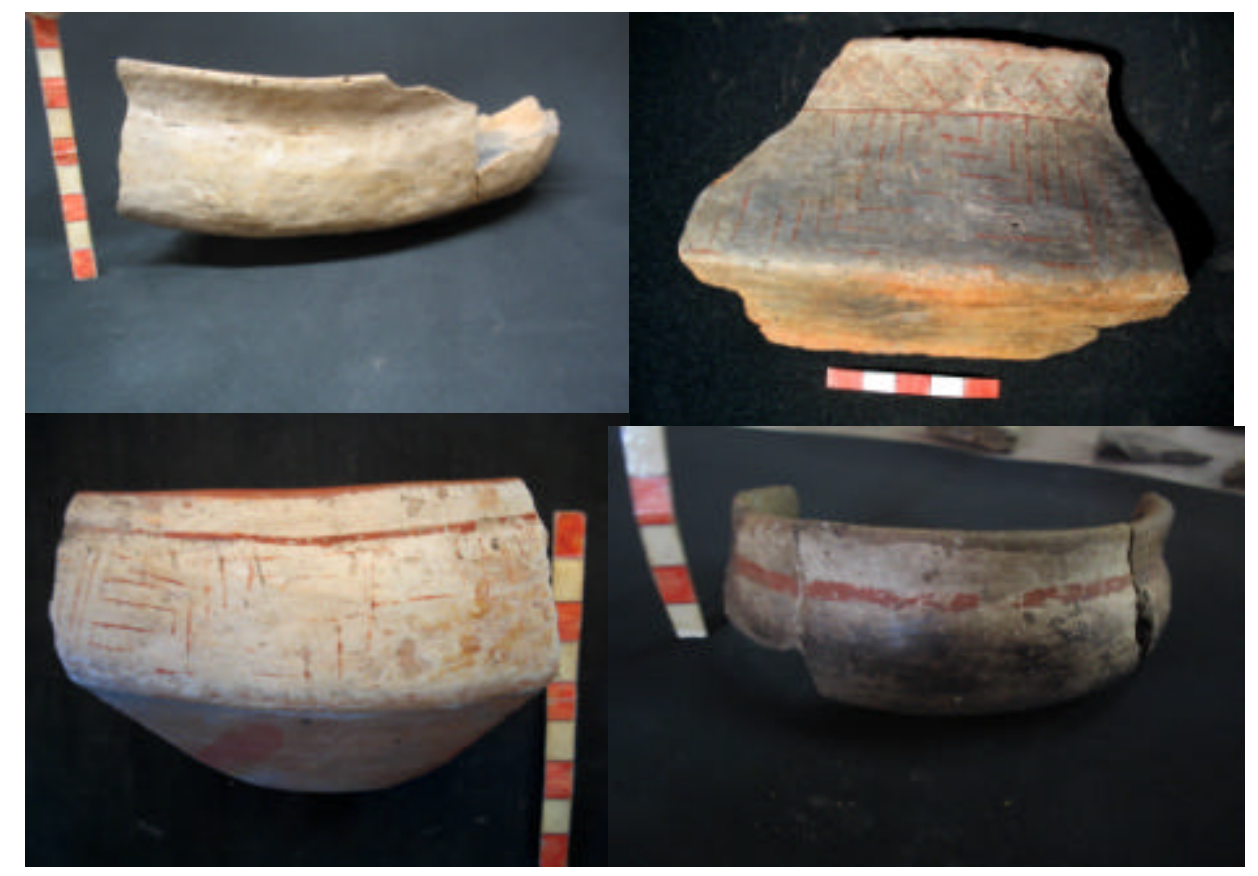

Foto 25 : Tigelas de beber. Em cima, à esquerda, tigela carenada com fundo aplanado. À direita, motivo de pintura. Abaixo, à esquerda, motivo de pintura. À direita, tigela com $8 \mathrm{~cm}$ de diâmetro. Escala em centímetros (fotos: Sérgio Klamt).

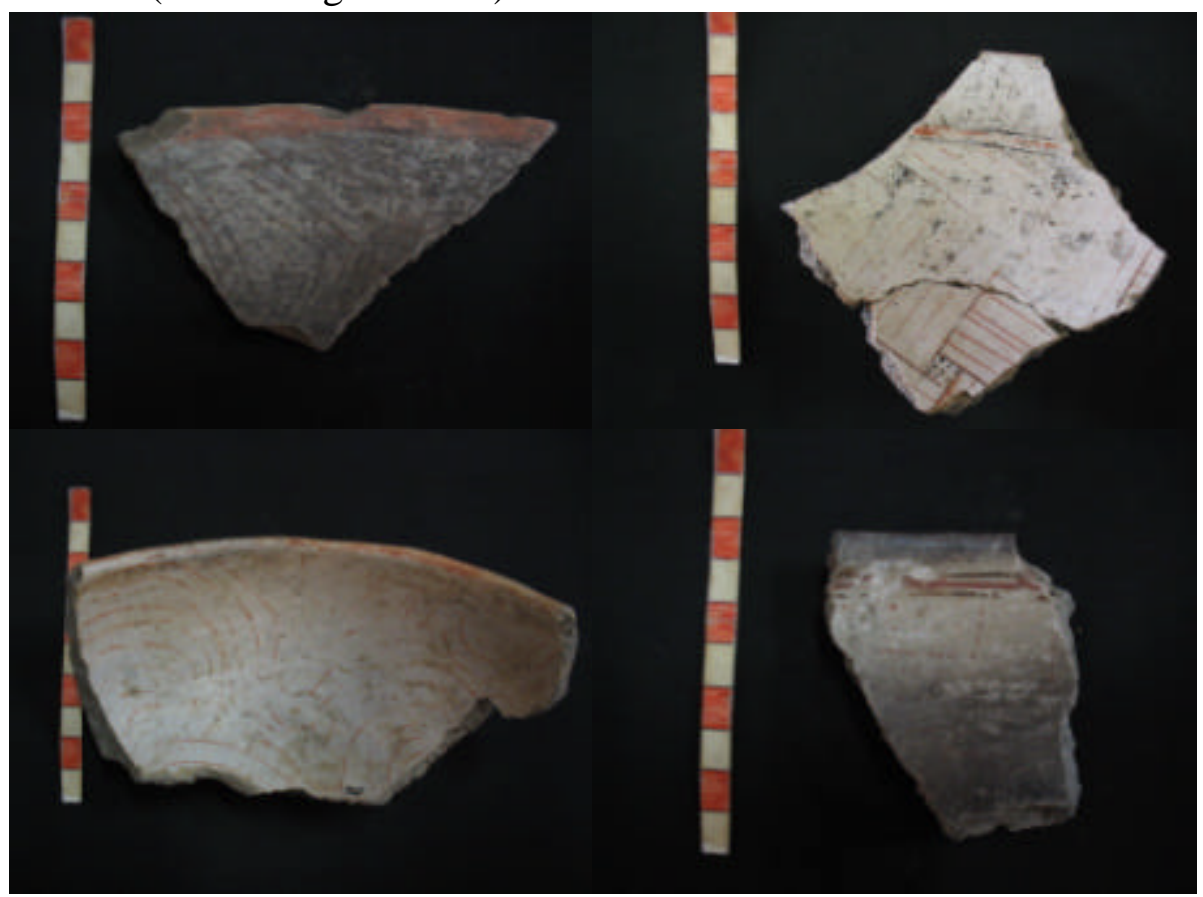

Foto 26: Motivos de pintura interno presentes nas tigelas de beber (fotos: Sérgio Klamt). 


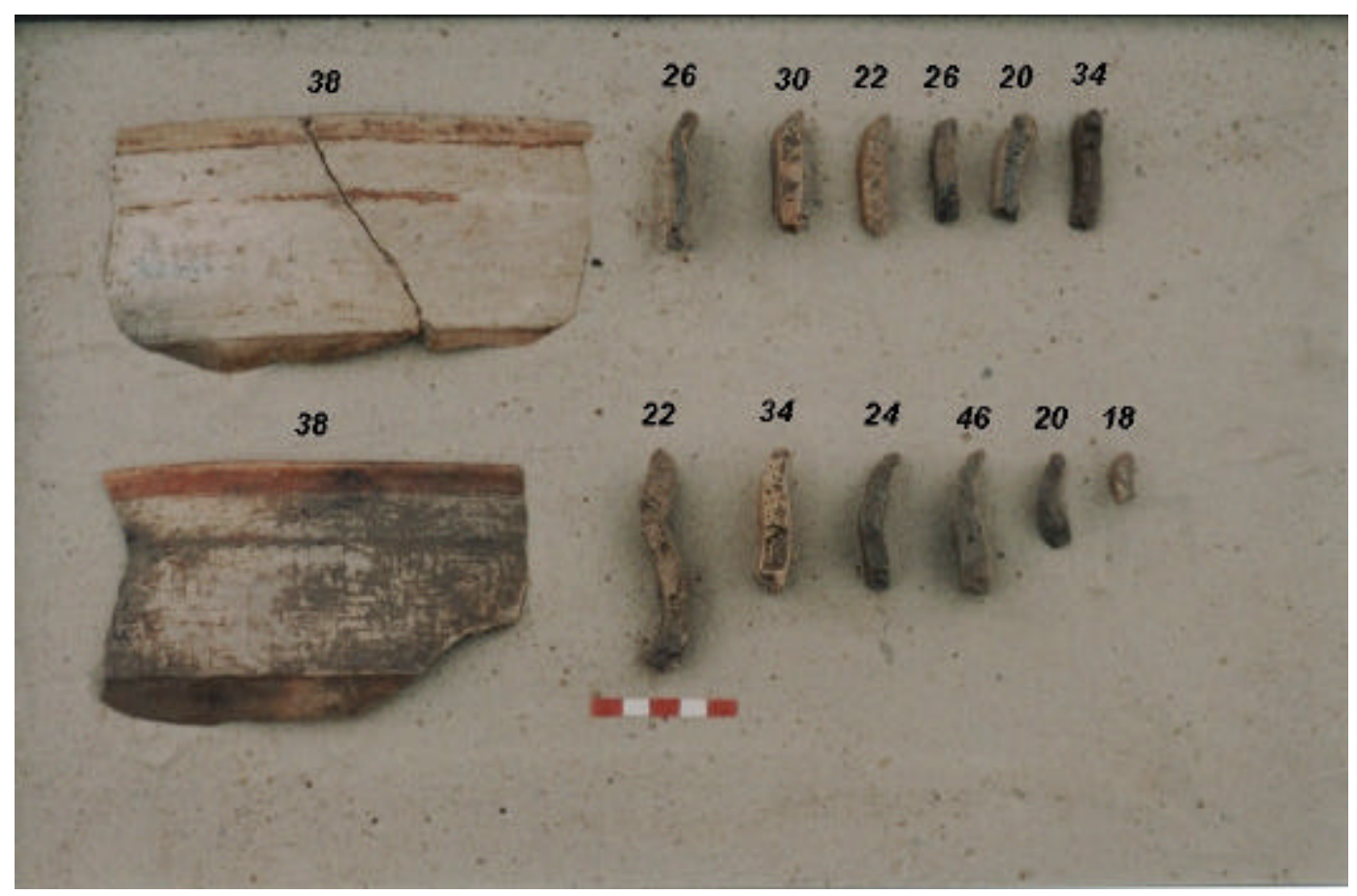

Foto 27 : Bordas de tigelas de beber. Escala em centímetros (foto: Sérgio Klamt).

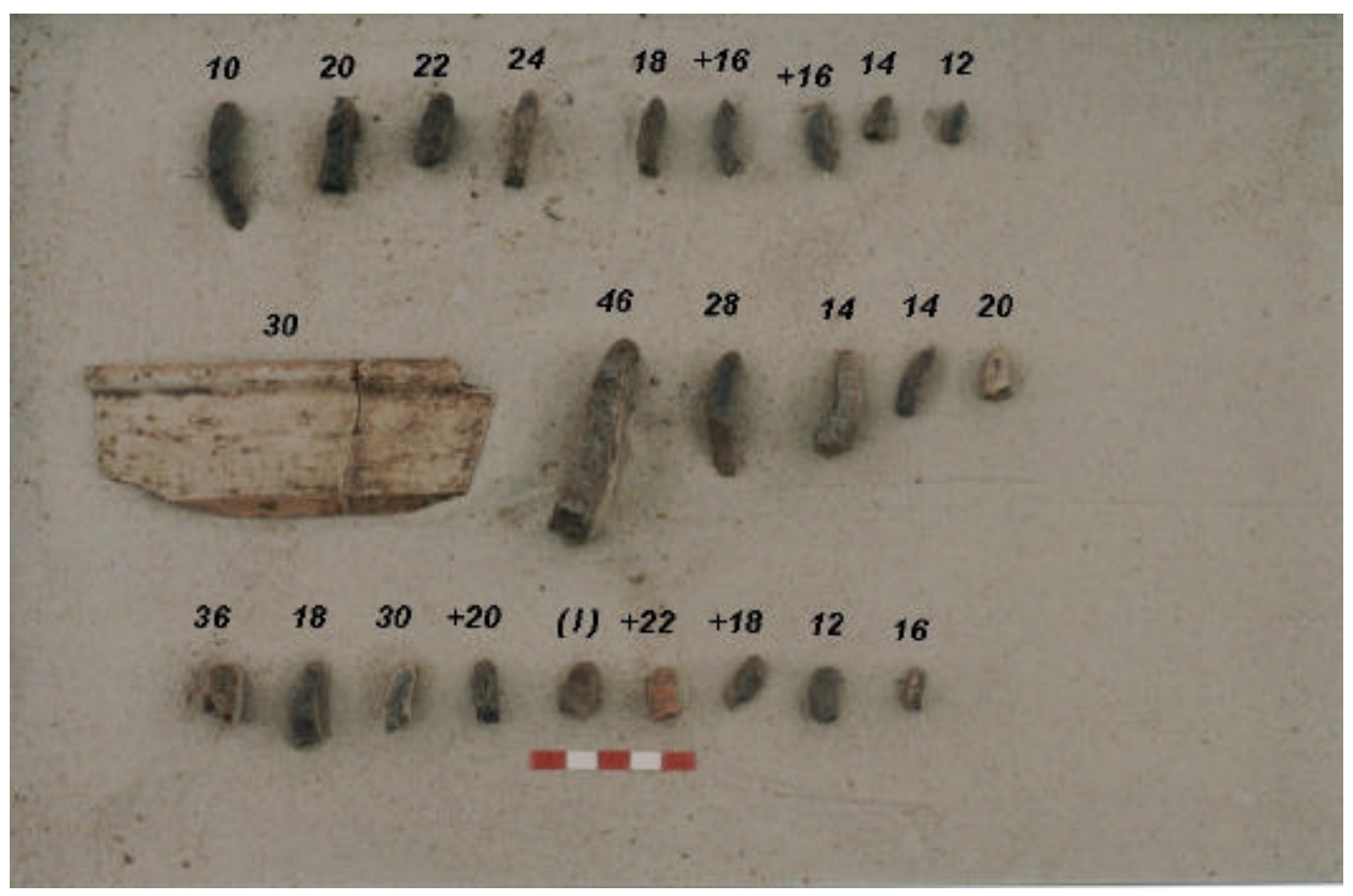

Foto 28: Bordas de tigelas de beber. Escala em centímetros (foto Sérgio Klamt). 


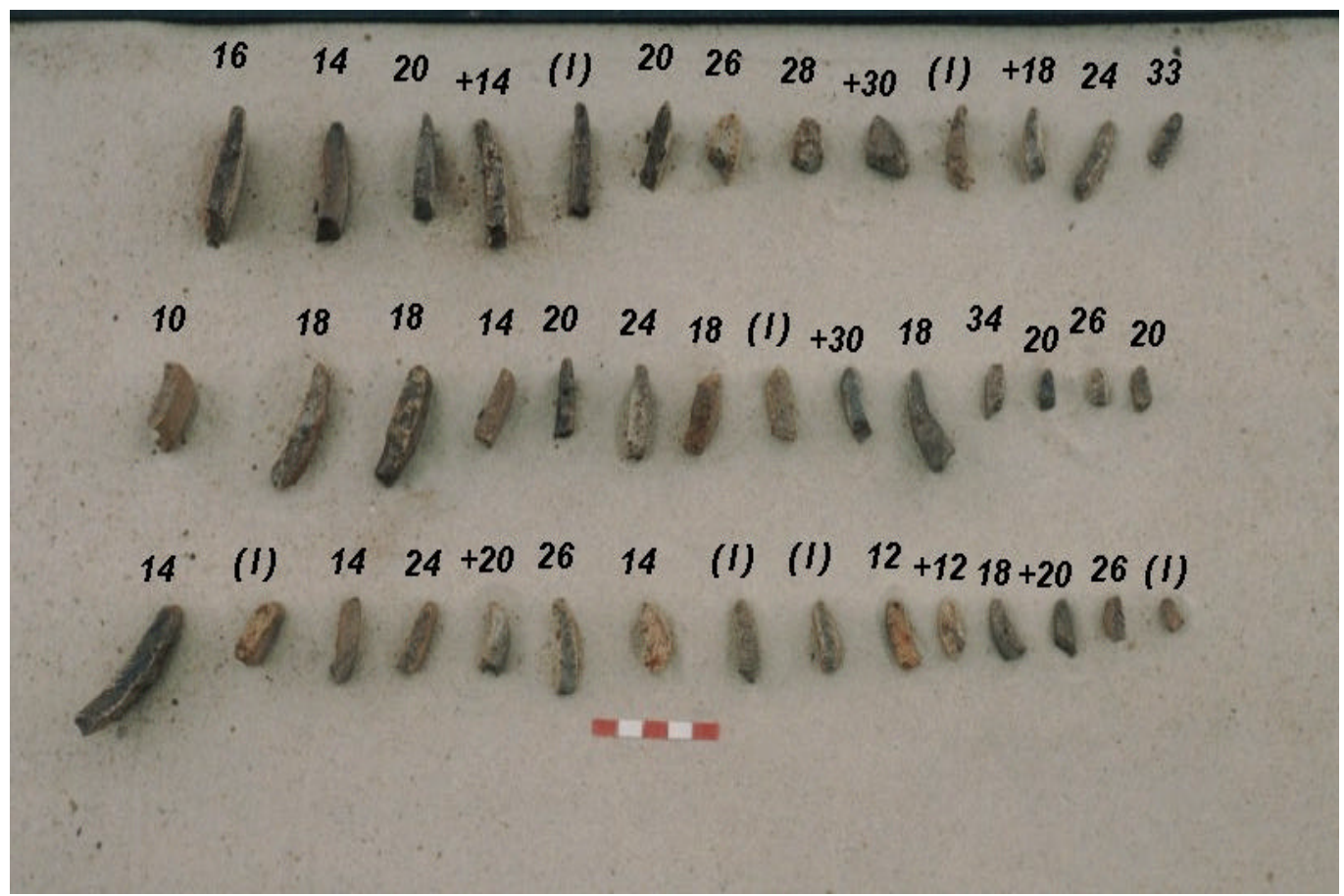

Foto 29: Bordas de tigelas de beber. Escala em centímetros (foto Sérgio Klamt).

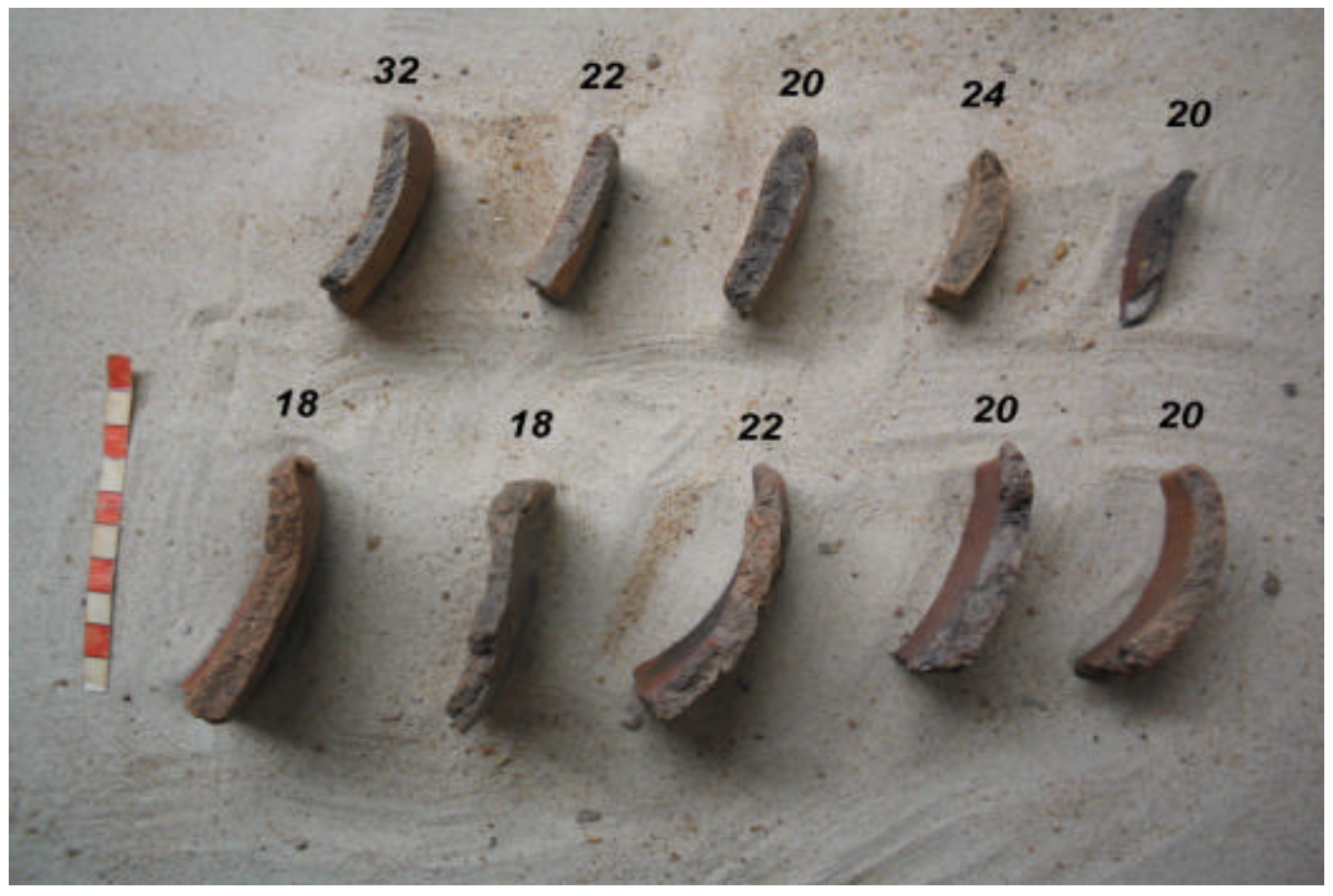

Foto 30 : Bordas de tigelas de beber com pintura vermelha interna. Escala em centímetros (foto: Sérgio Klamt). 


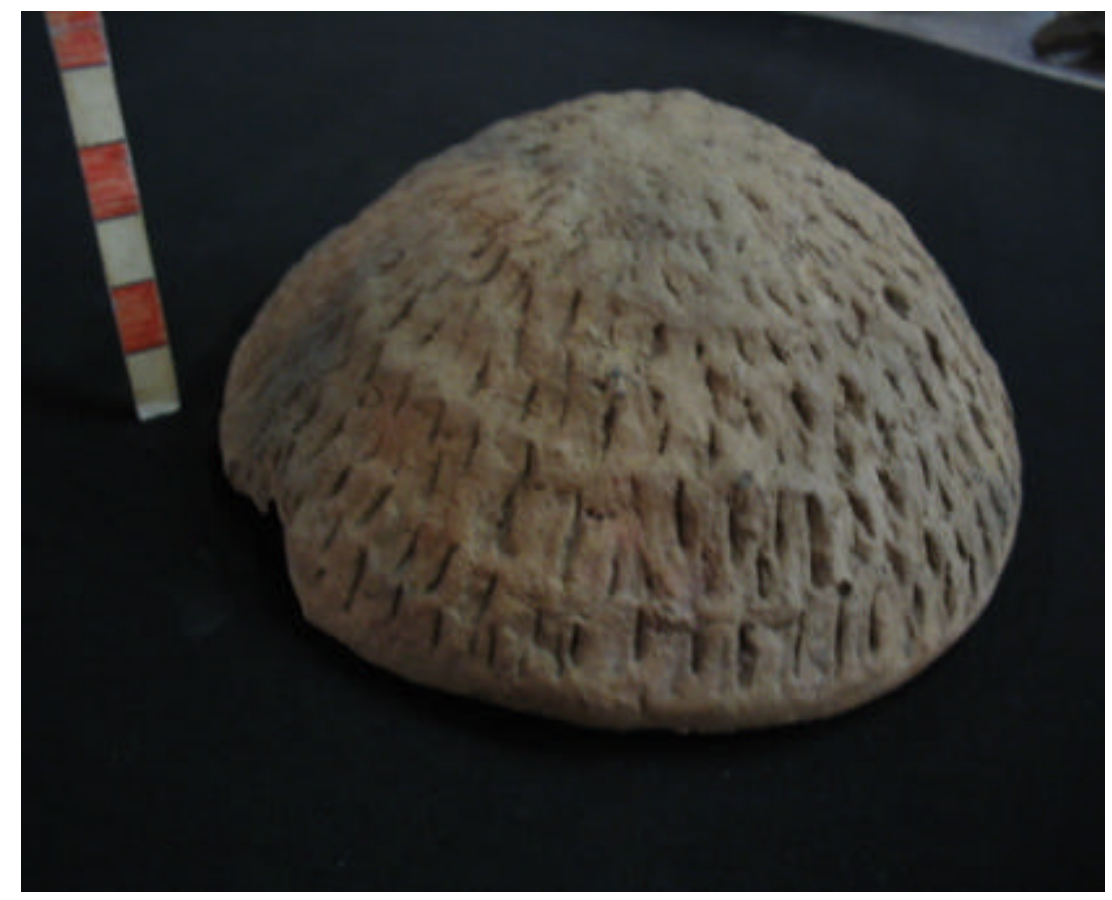

Foto 31: Pratos corrugado-ungulado. Diâmetro de boca $12 \mathrm{~cm}$ (Foto Sérgio Klamt).

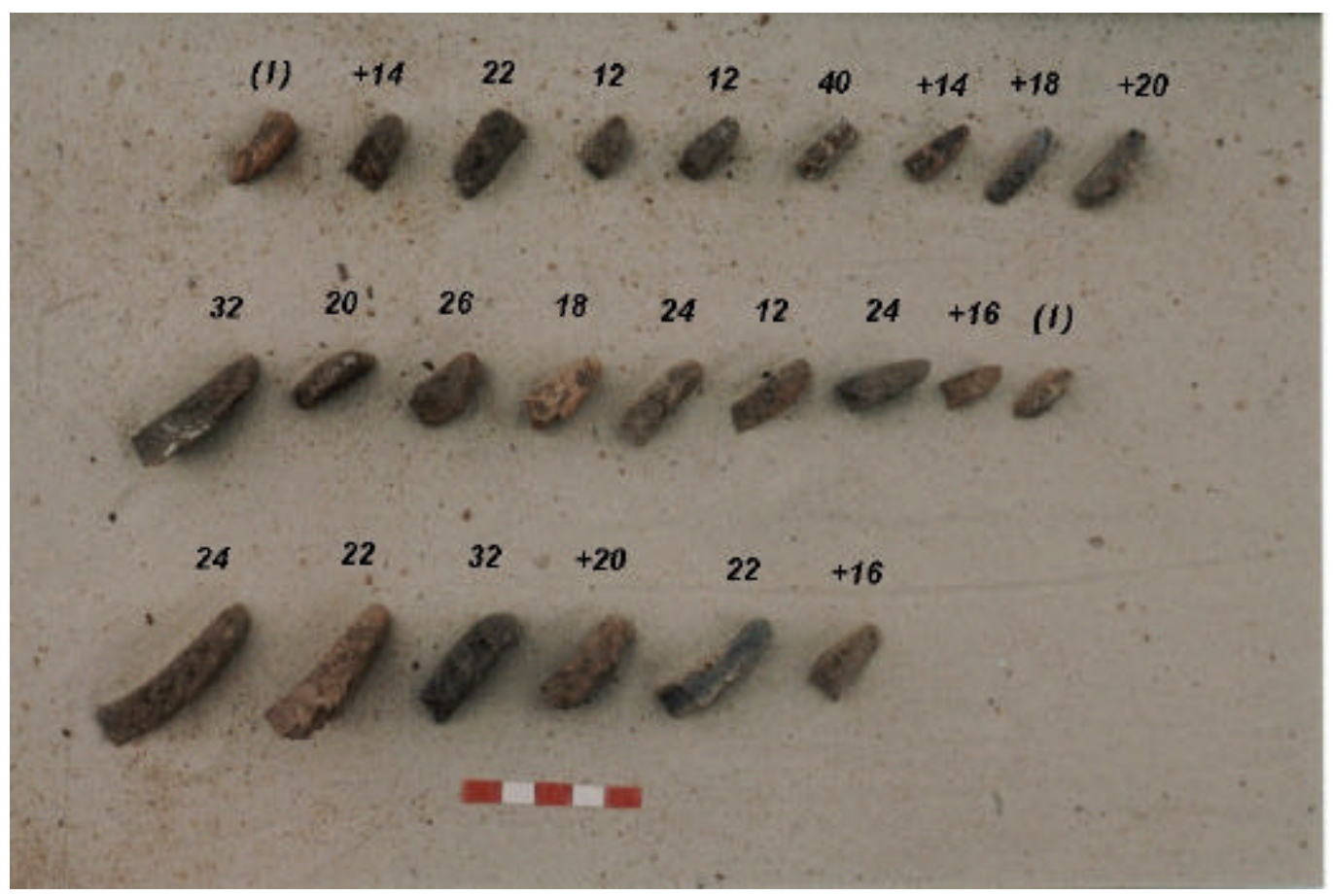

Foto 32 : Pratos com diferentes tratamentos de superfície e decoração (Foto Sérgio Klamt). 


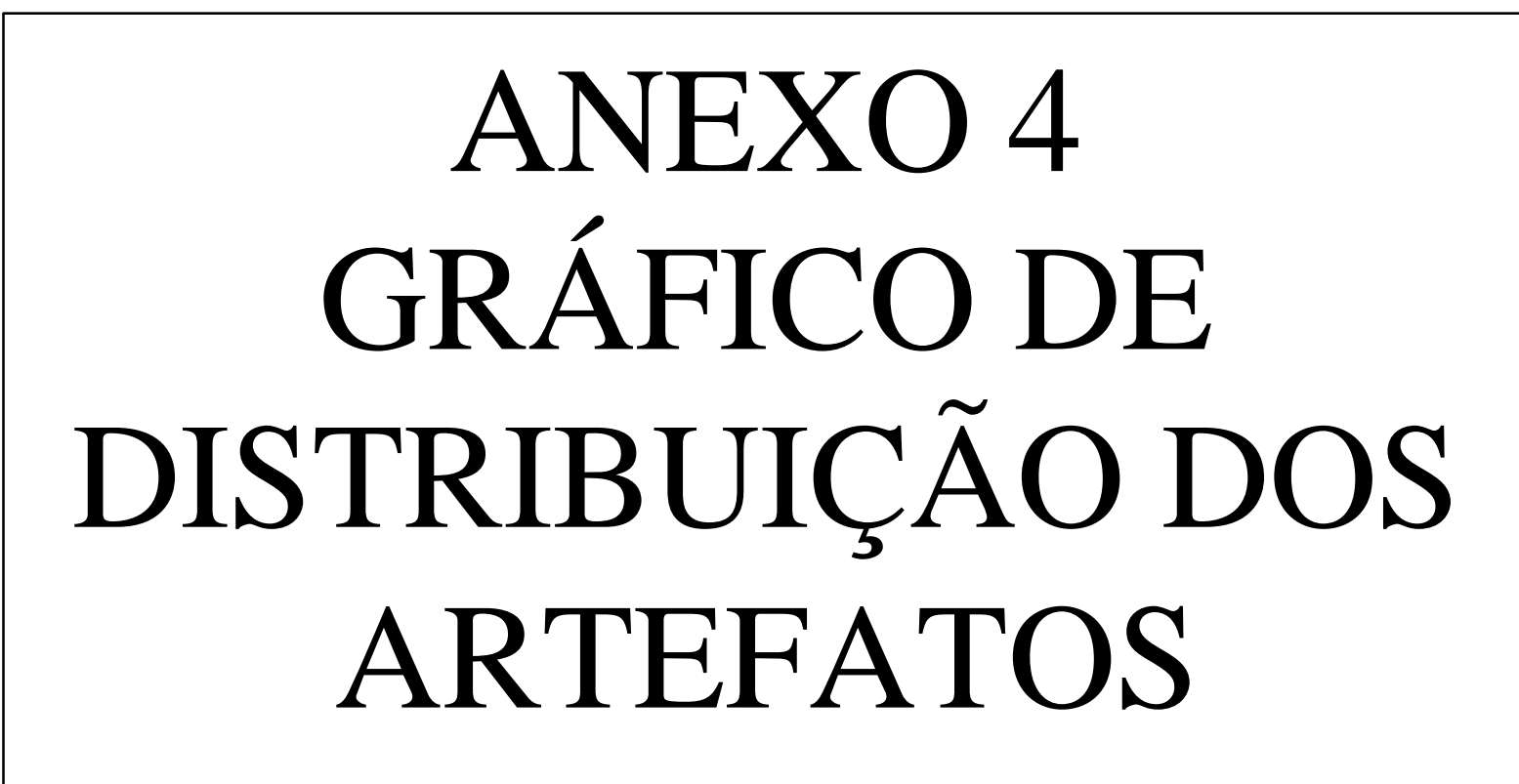




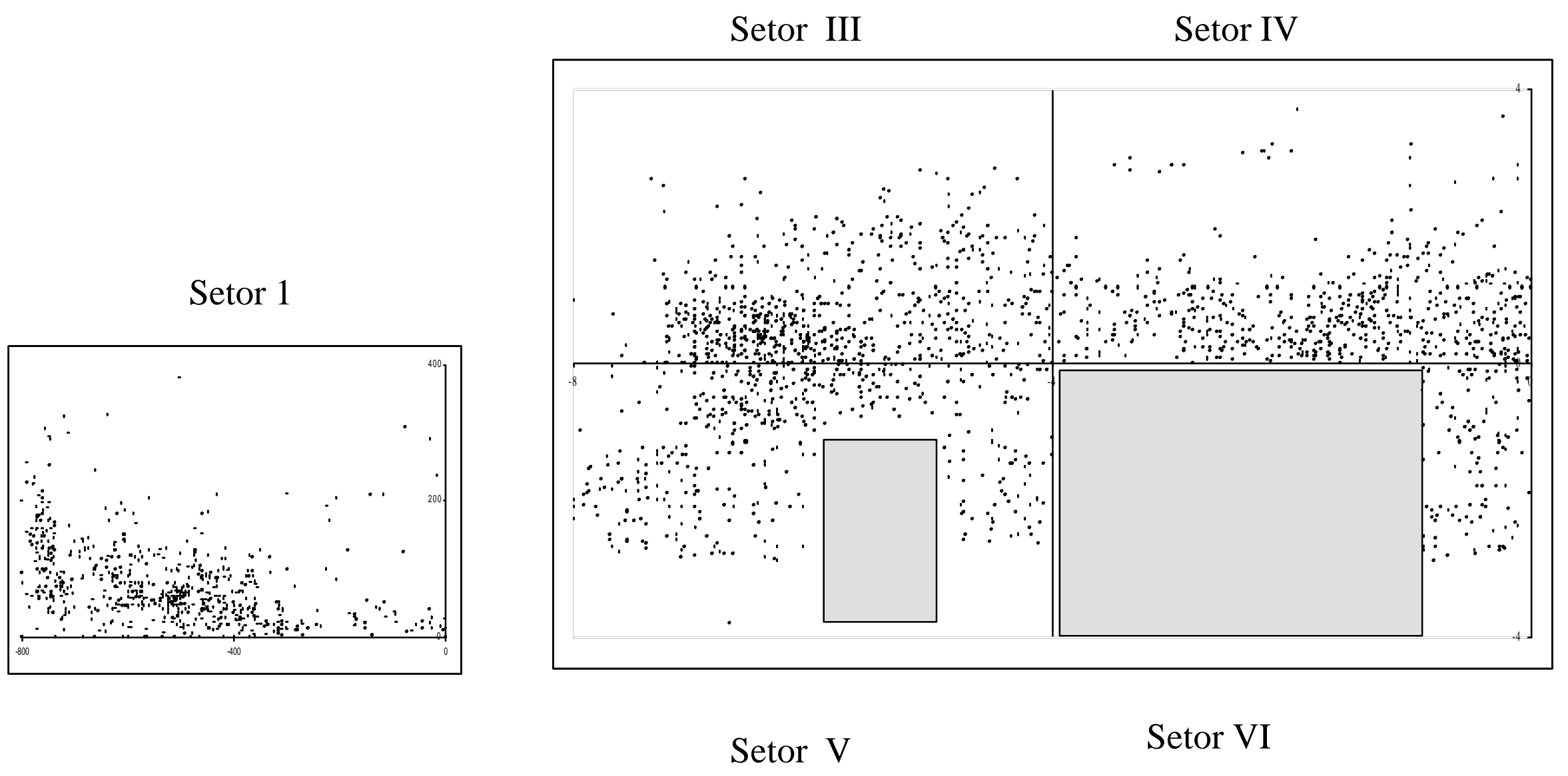

Gráfico 1: Plano geral da escavação com a totalidade dos testemunhos plotados. As áreas pontilhadas correspondem a locais não escavados. Ver Anexo 1: desenho 4 e Anexo 2: foto 15. 
Soares,A.L.R. 2004 - Contribuição à Arqueologia Guarani: estudo do sítio Röpke

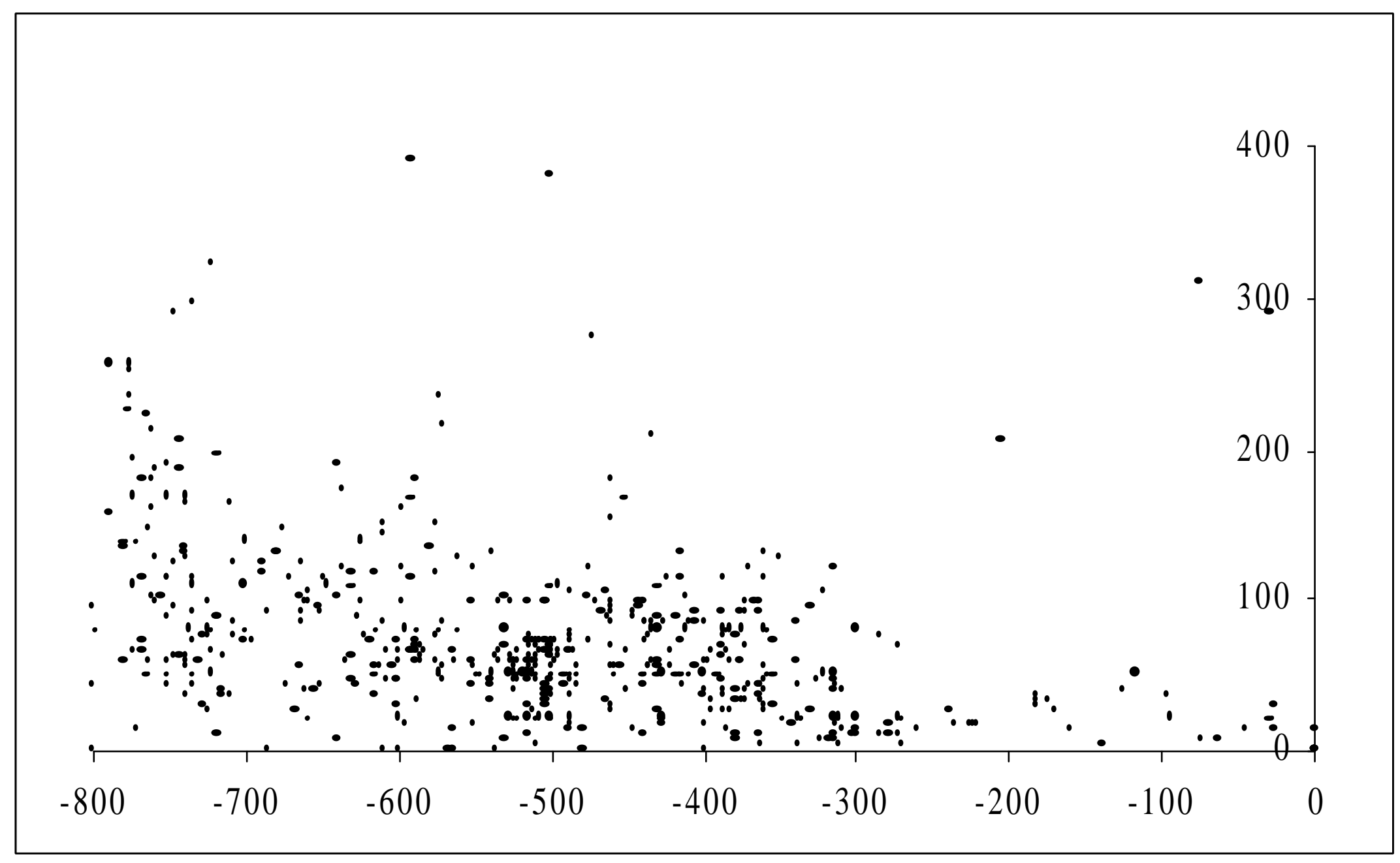

Gráfico 2: Dispersão de todos os testemunhos líticos do setor 1 . 


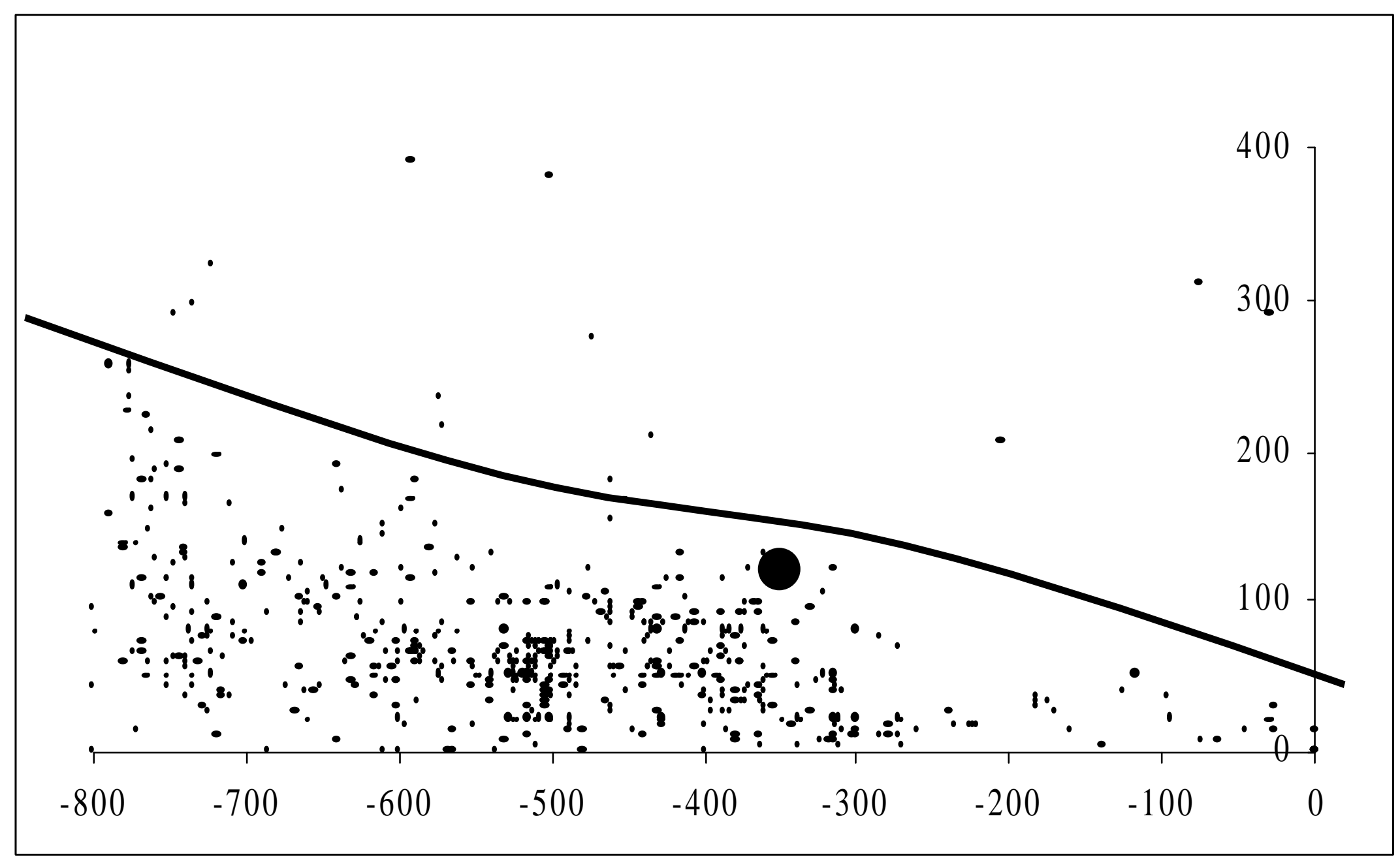

Gráfico 3: Dispersão de todos os testemunhos líticos do setor 1. A linha contínua é semelhante ao gráfico de distribuição de fragmentos cerâmicos, delimitando a área de circulação. 
Soares,A.L.R. 2004 - Contribuição à Arqueologia Guarani: estudo do sítio Röpke

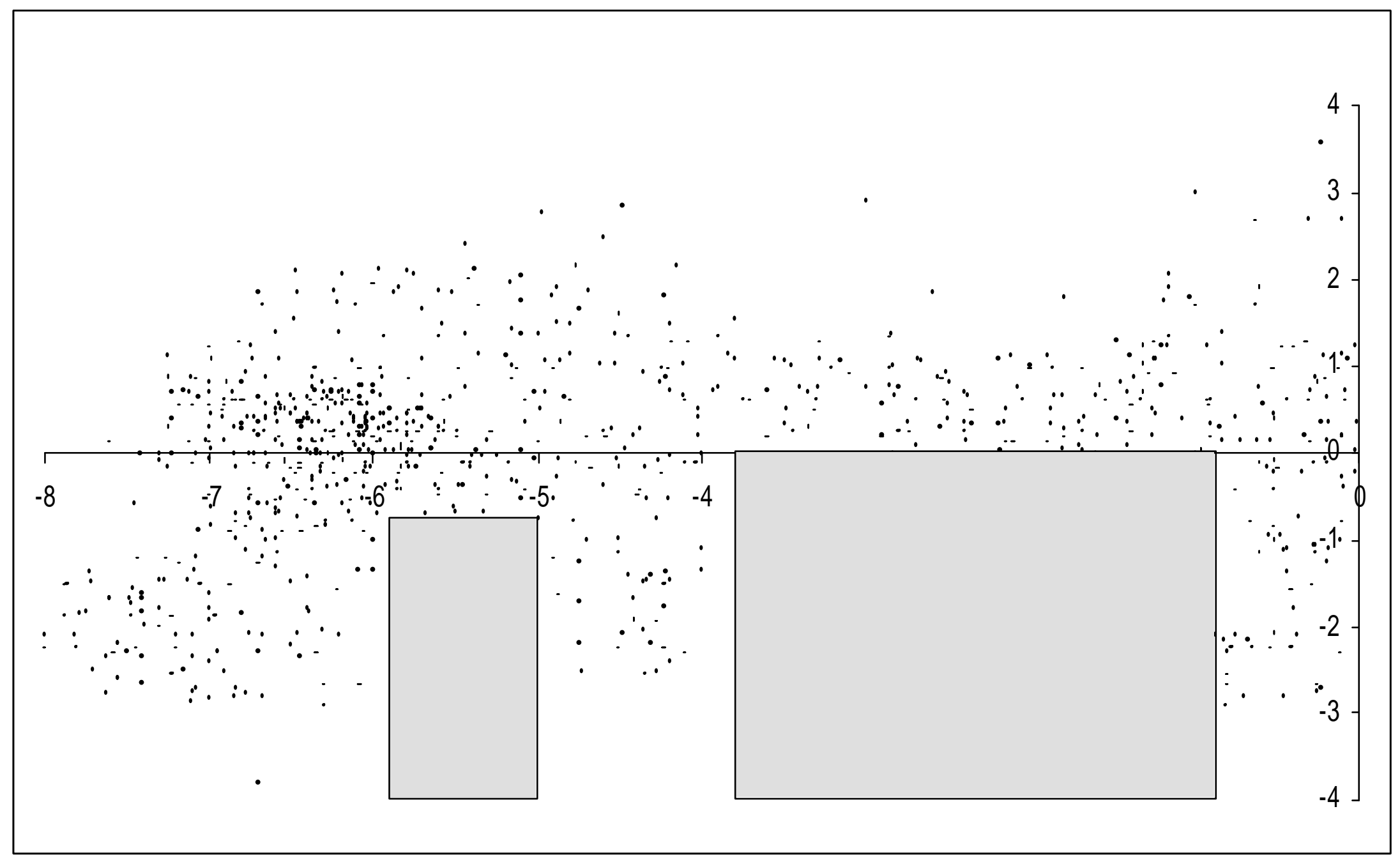

Gráfico 4: Dispersão de todos os testemunhos líticos dos setores III a VI. 
Soares,A.L.R. 2004 - Contribuição à Arqueologia Guarani: estudo do sítio Röpke

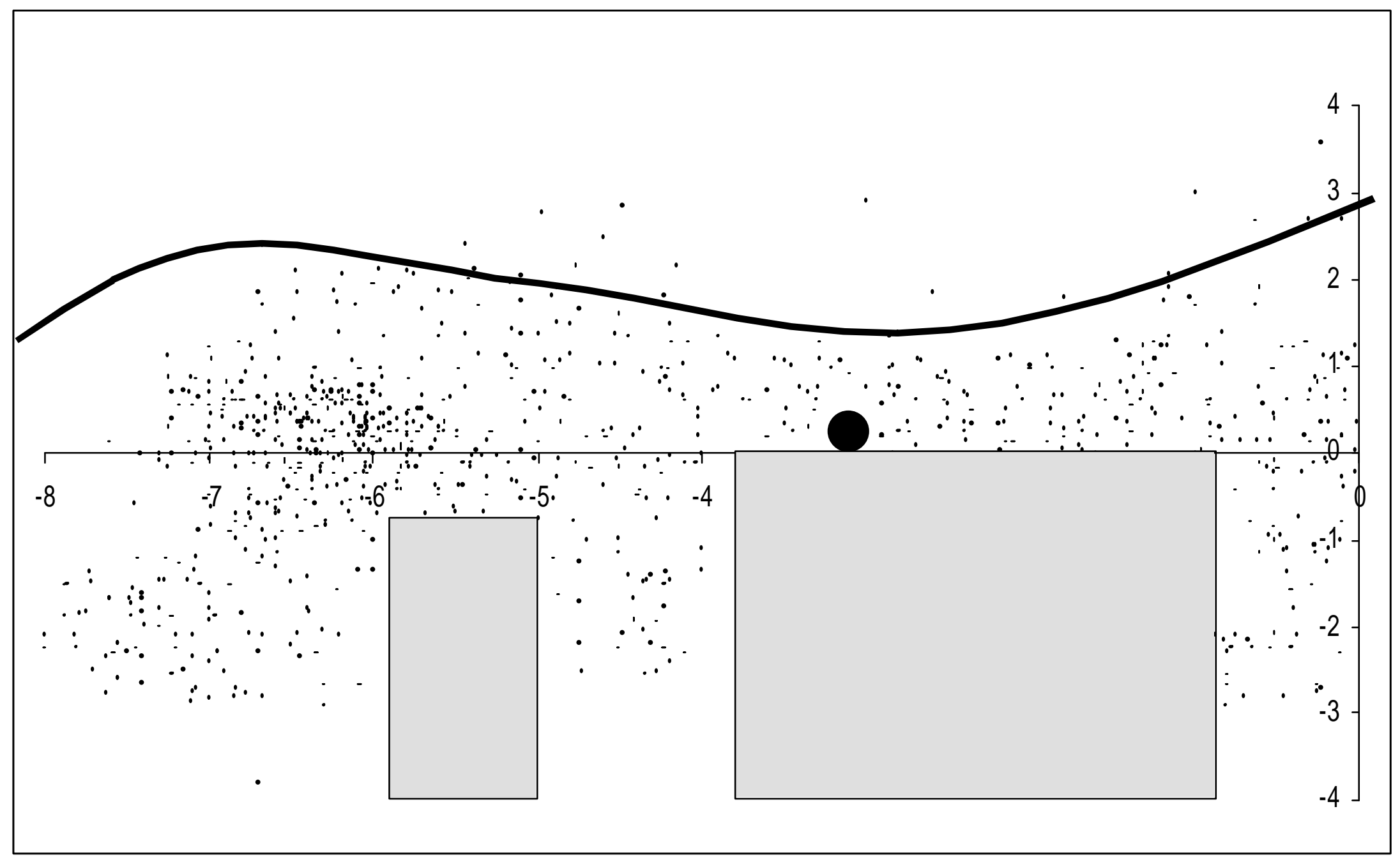

Gráfico 5: Dispersão de todos os testemunhos líticos dos setores III a VI. A linha contínua é semelhante ao gráfico de distribuição de fragmentos cerâmicos, delimitando a área de circulação. 
Soares,A.L.R. 2004 - Contribuição à Arqueologia Guarani: estudo do sítio Röpke

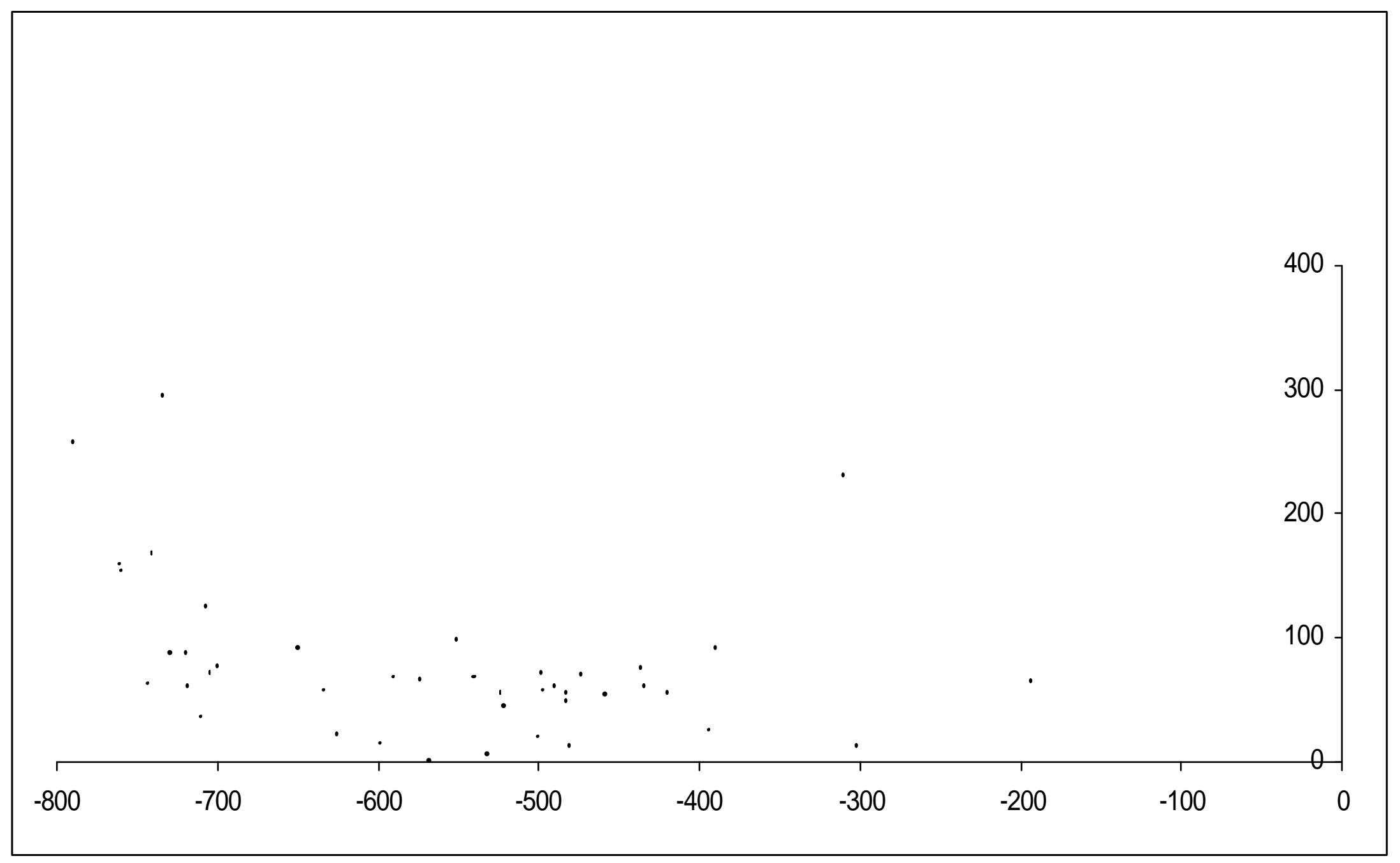

Gráfico 6: Testemunhos brutos. Seixos de basalto, sem sinais de uso. Setor 1. 
Soares,A.L.R. 2004 - Contribuição à Arqueologia Guarani: estudo do sítio Röpke

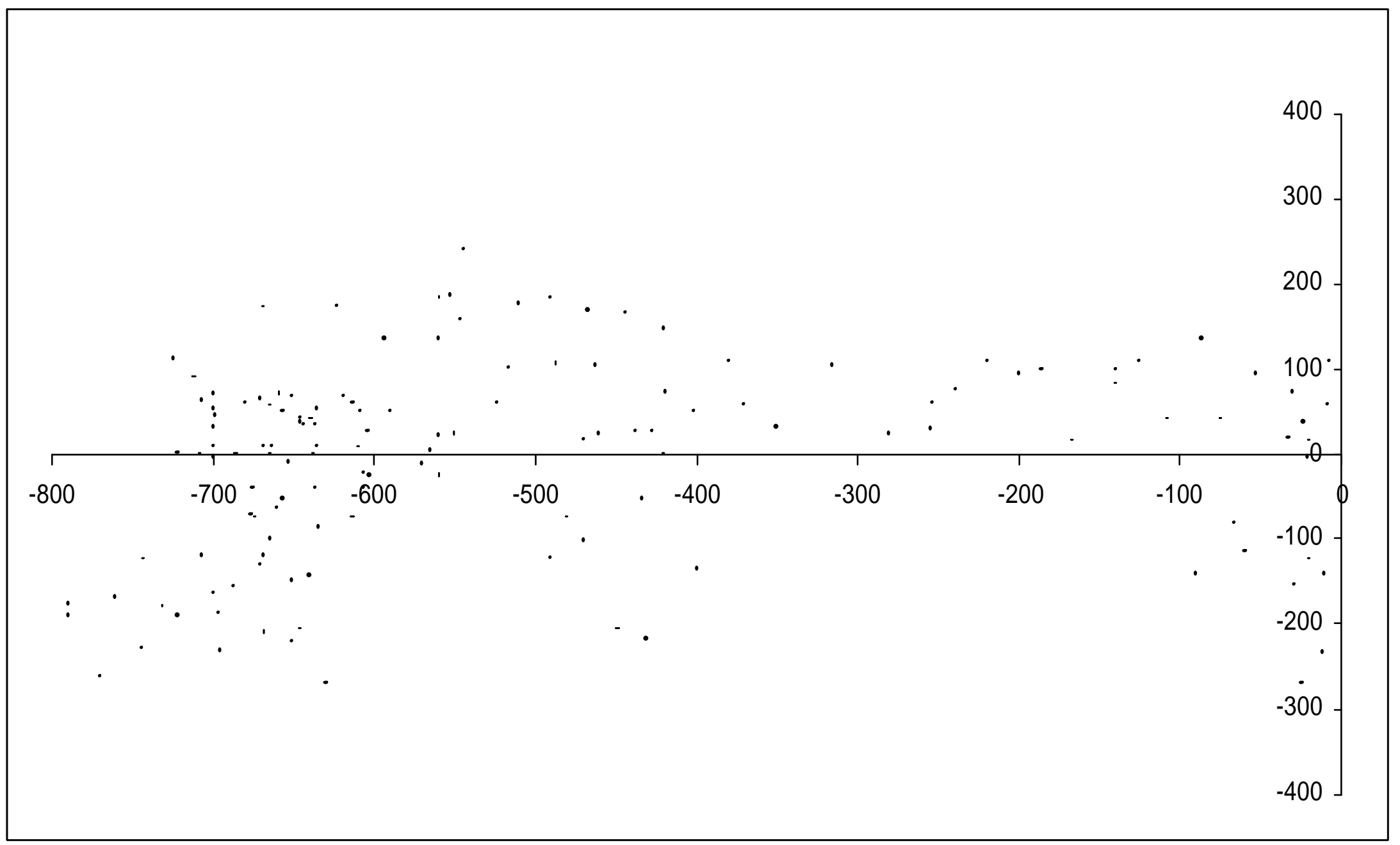

Gráfico 7: Testemunhos brutos. Seixos de basalto sem modificação. Setores III a VI. 
Soares,A.L.R. 2004 - Contribuição à Arqueologia Guarani: estudo do sítio Röpke

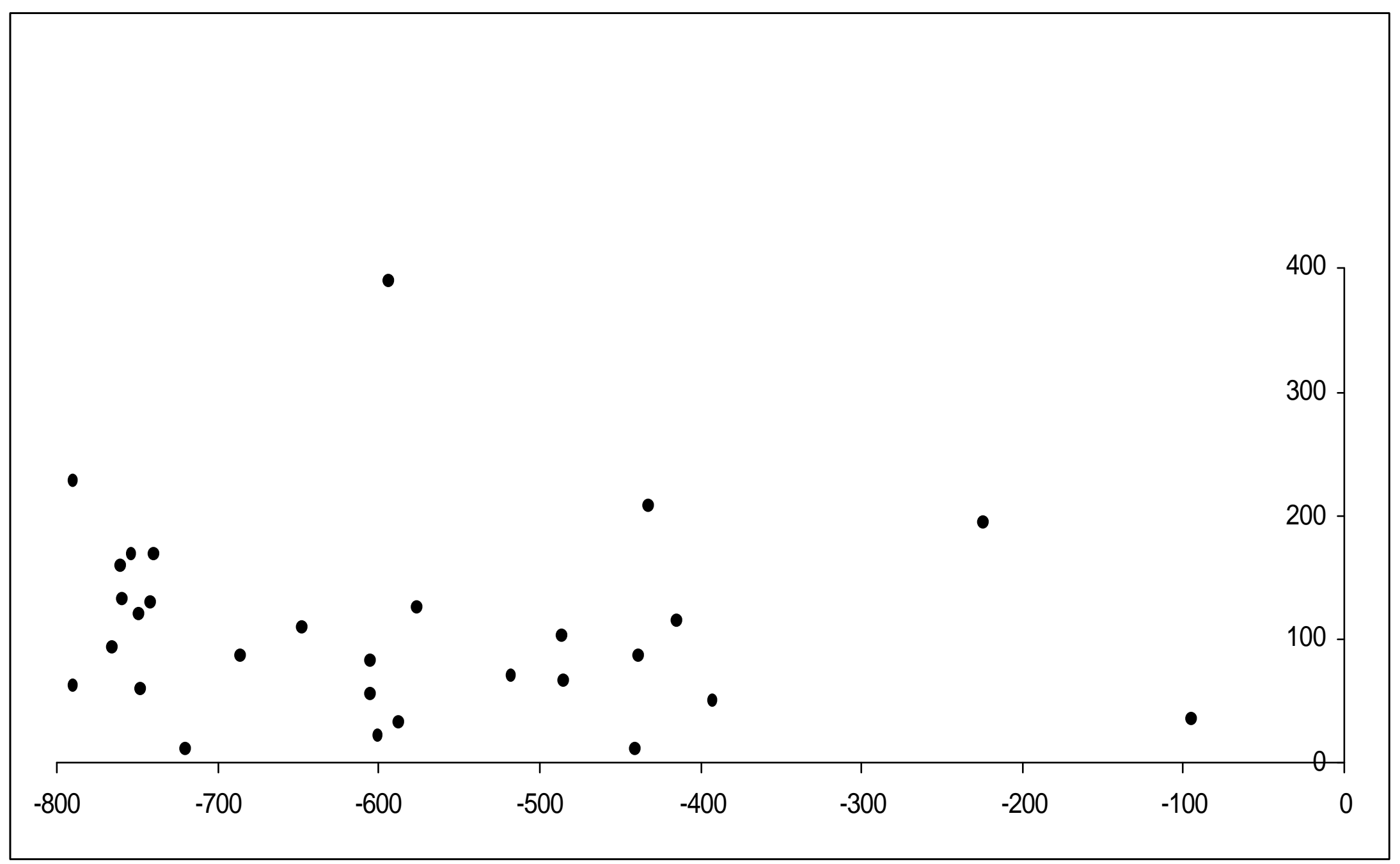

Gráfico 8: Testemunhos brutos. Arenitos sem modificação. Setor 1. 
Soares,A.L.R. 2004 - Contribuição à Arqueologia Guarani: estudo do sítio Röpke

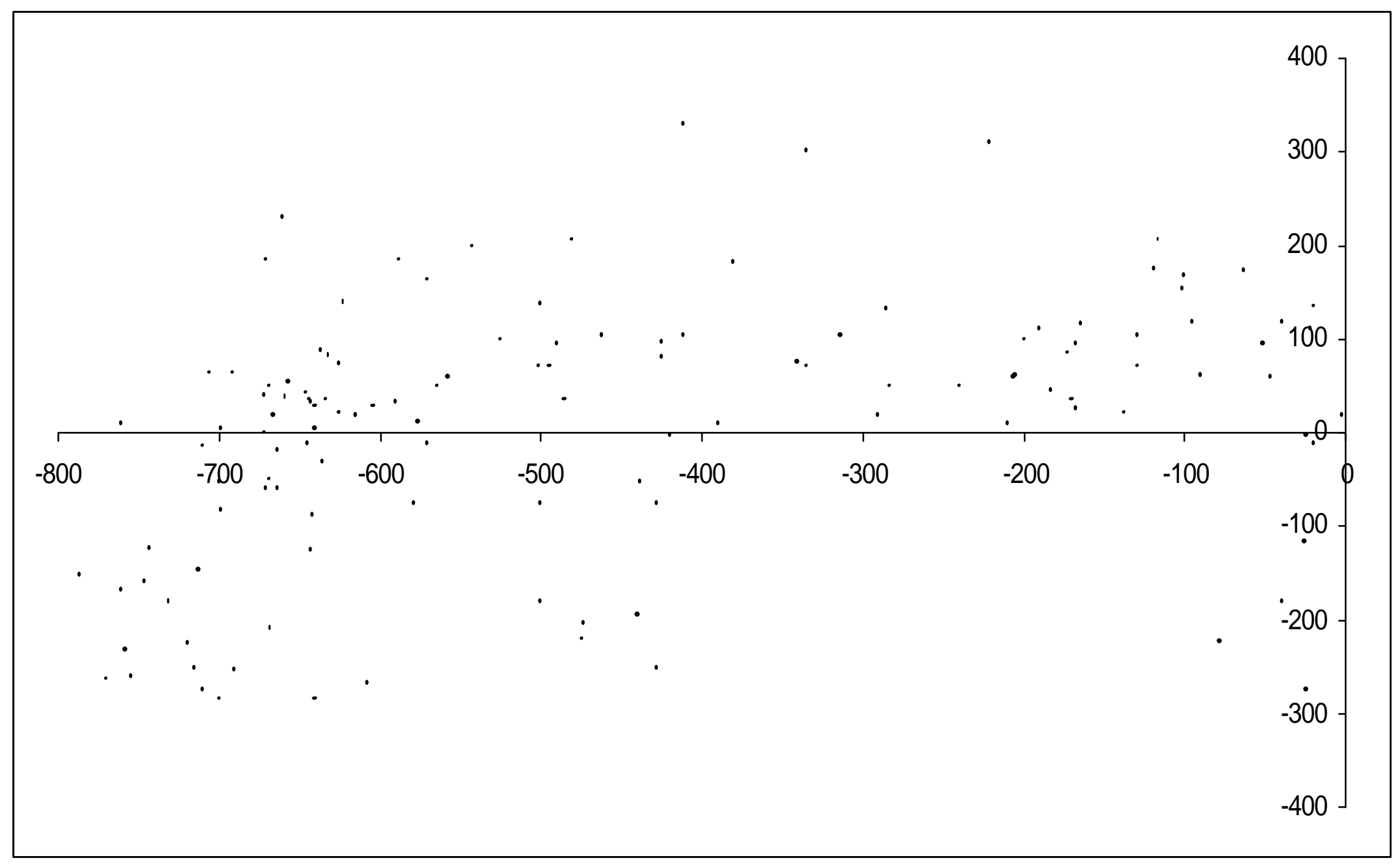

Gráfico 9: Testemunhos brutos. Arenitos sem modificação. Setores III a VI. 
Soares,A.L.R. 2004 - Contribuição à Arqueologia Guarani: estudo do sítio Röpke

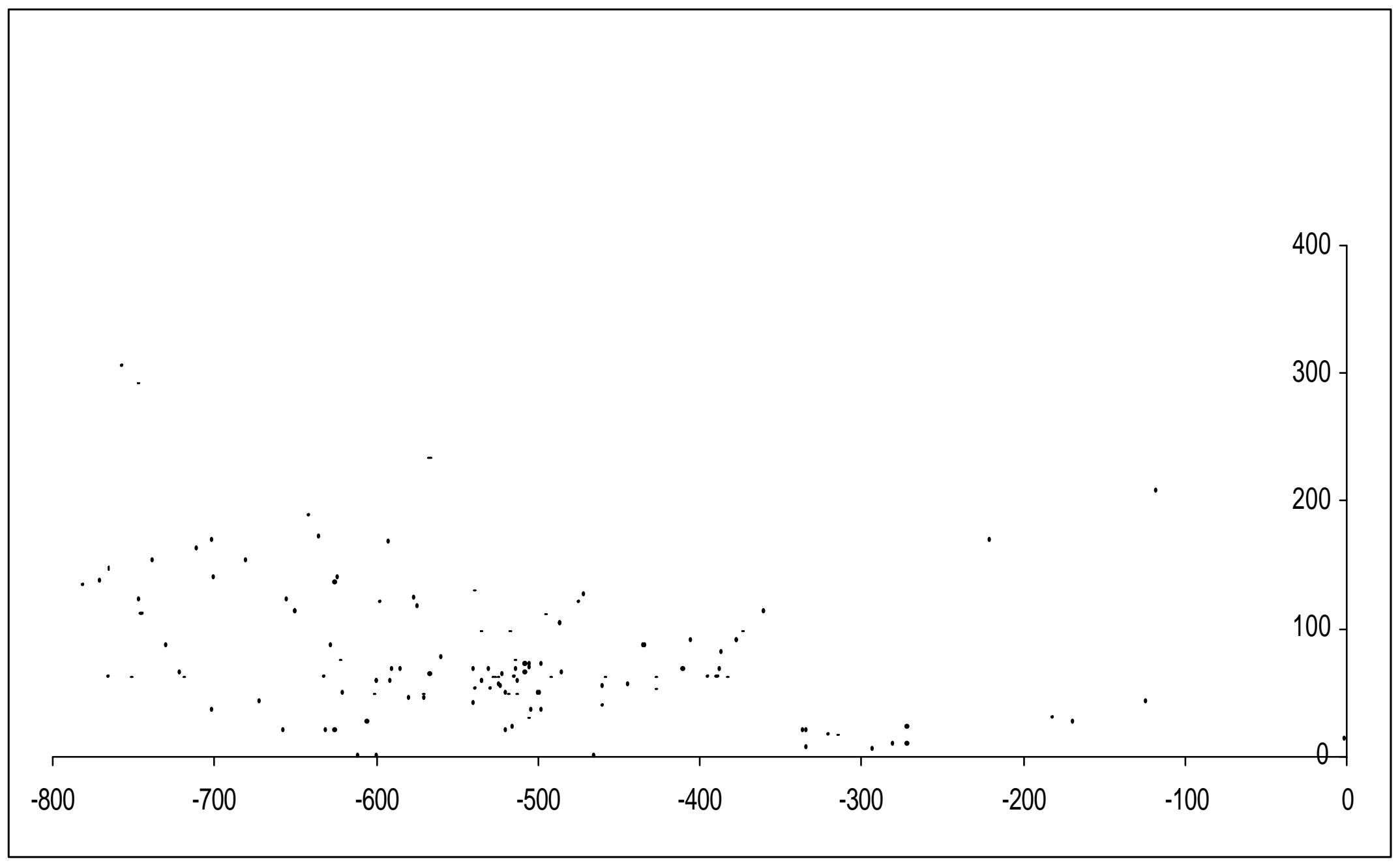

Gráfico 10: Testemunhos modificados: dispersão das termóforas de basalto no setor 1 . 
Soares,A.L.R. 2004 - Contribuição à Arqueologia Guarani: estudo do sítio Röpke

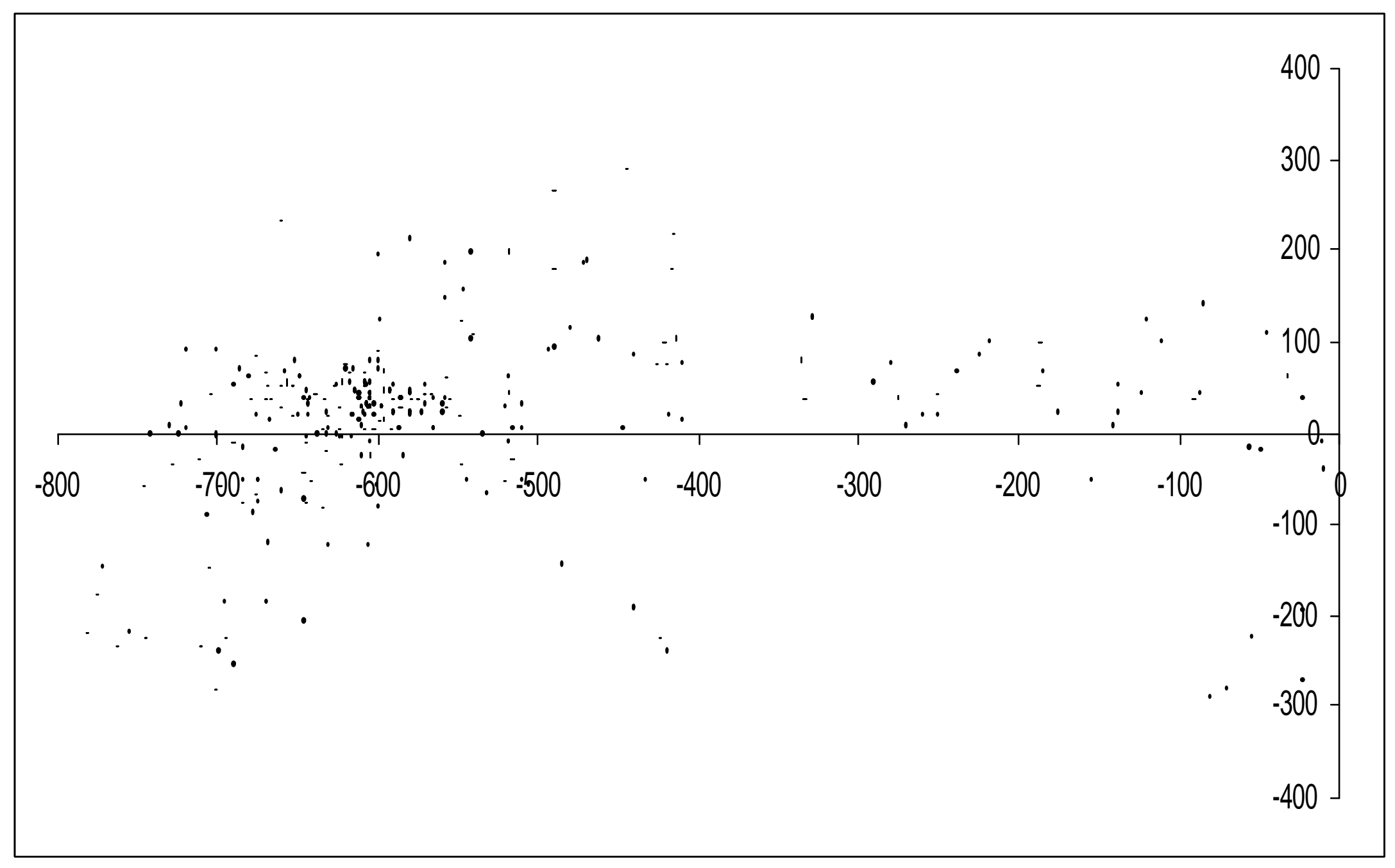

Gráfico 11: Testemunhos modificados: dispersão das termóforas de basalto nos setores III a VI. 
Soares,A.L.R. 2004 - Contribuição à Arqueologia Guarani: estudo do sítio Röpke

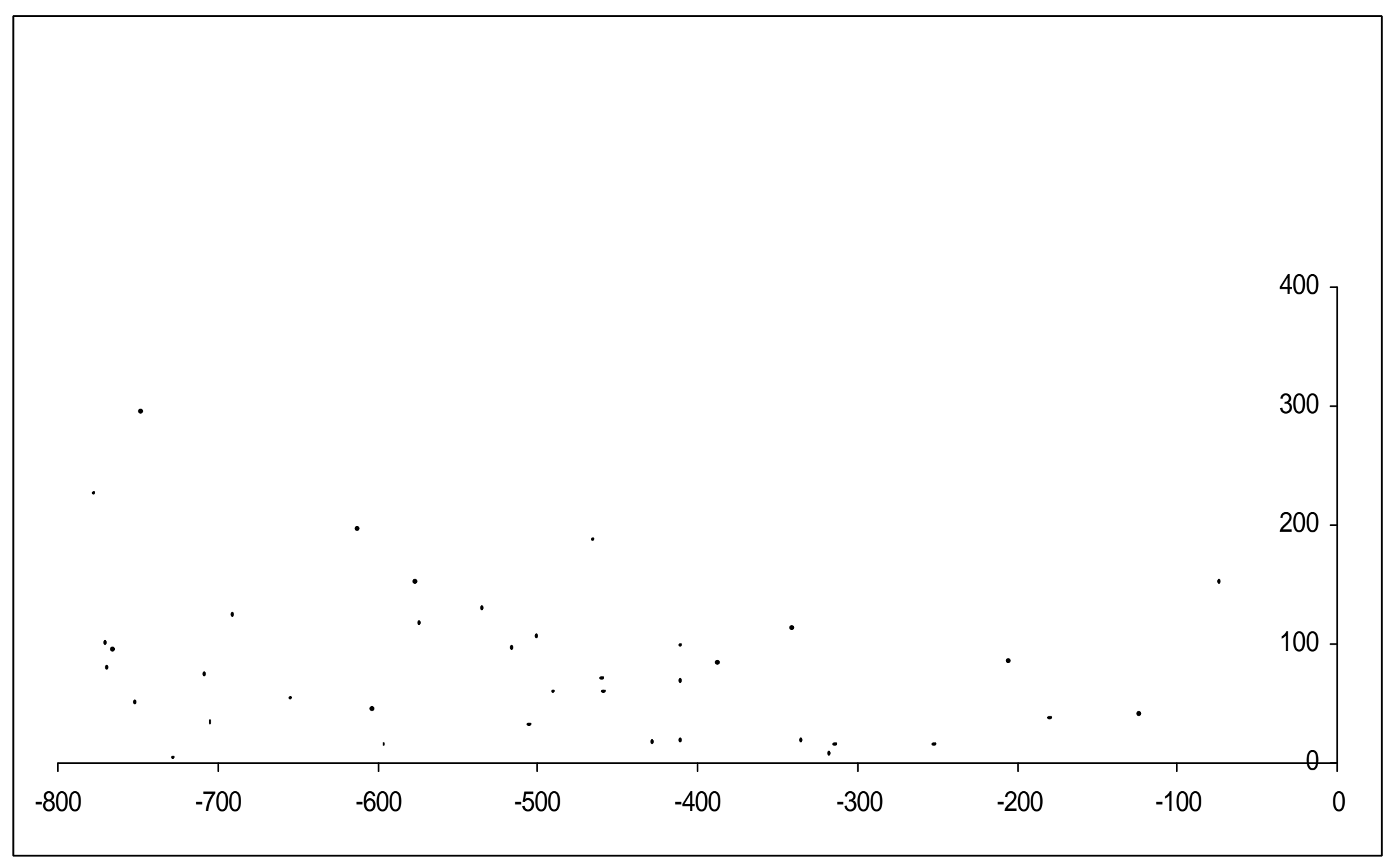

Gráfico 12: Testemunhos modificados: dispersão das termóforas de glabro no setor 1. 
Soares,A.L.R. 2004 - Contribuição à Arqueologia Guarani: estudo do sítio Röpke

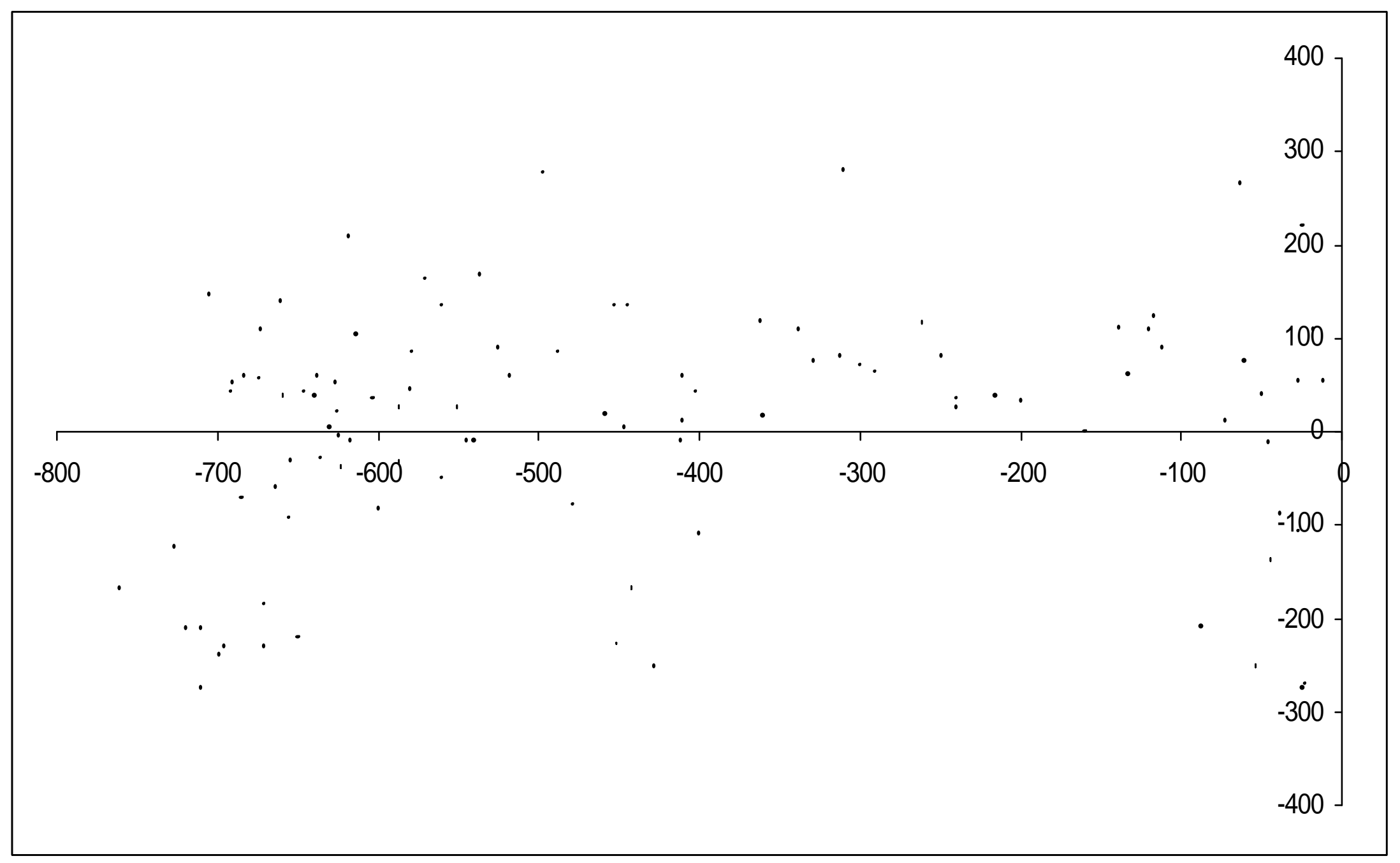

Gráfico 13: Testemunhos modificados: dispersão das termóforas de glabro nos setores III a VI. 
Soares,A.L.R. 2004 - Contribuição à Arqueologia Guarani: estudo do sítio Röpke

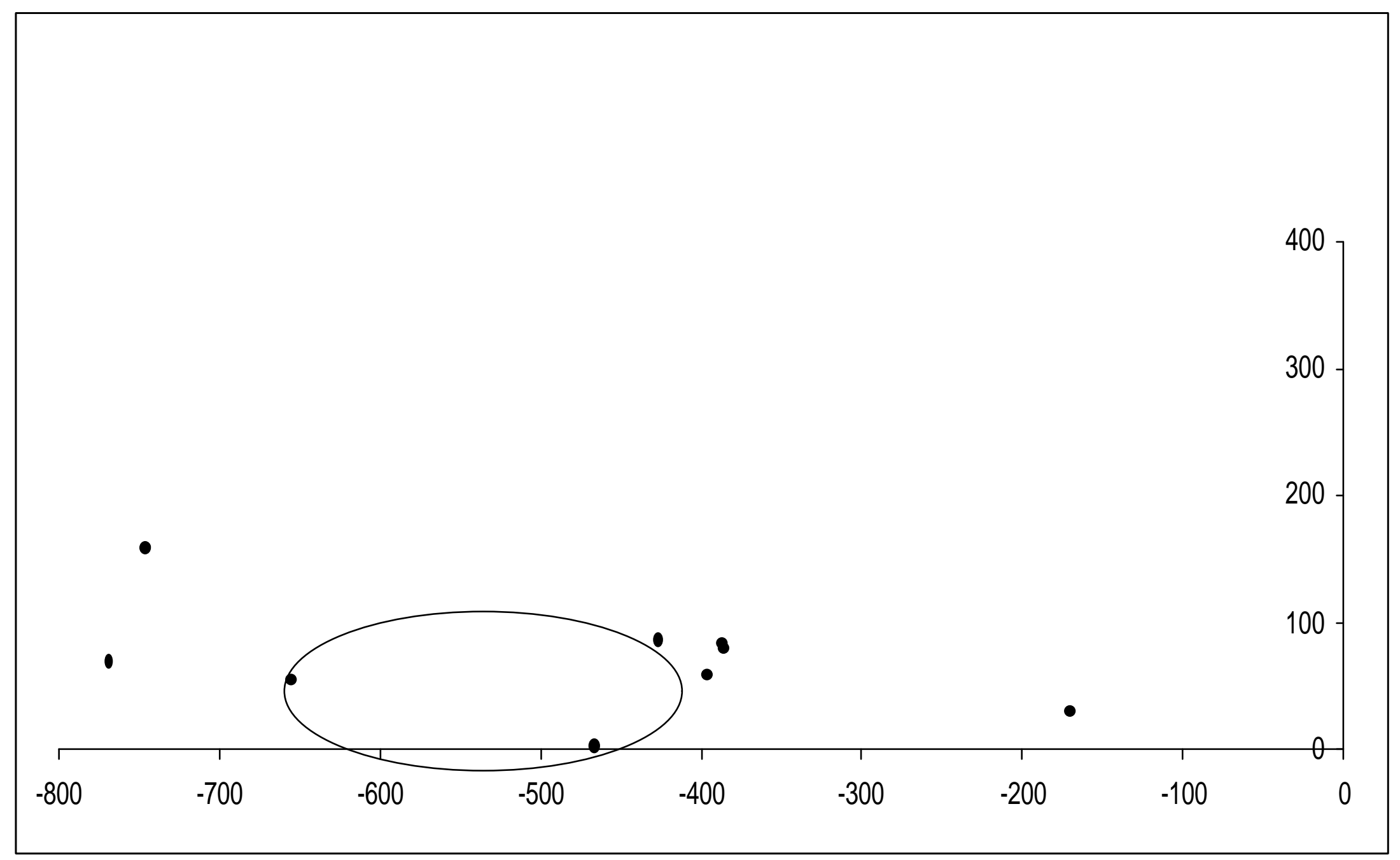

Gráfico 14: Dispersão dos afiadores em canaleta. Na elipse, área de concentração de artefatos. 
Soares,A.L.R. 2004 - Contribuição à Arqueologia Guarani: estudo do sítio Röpke

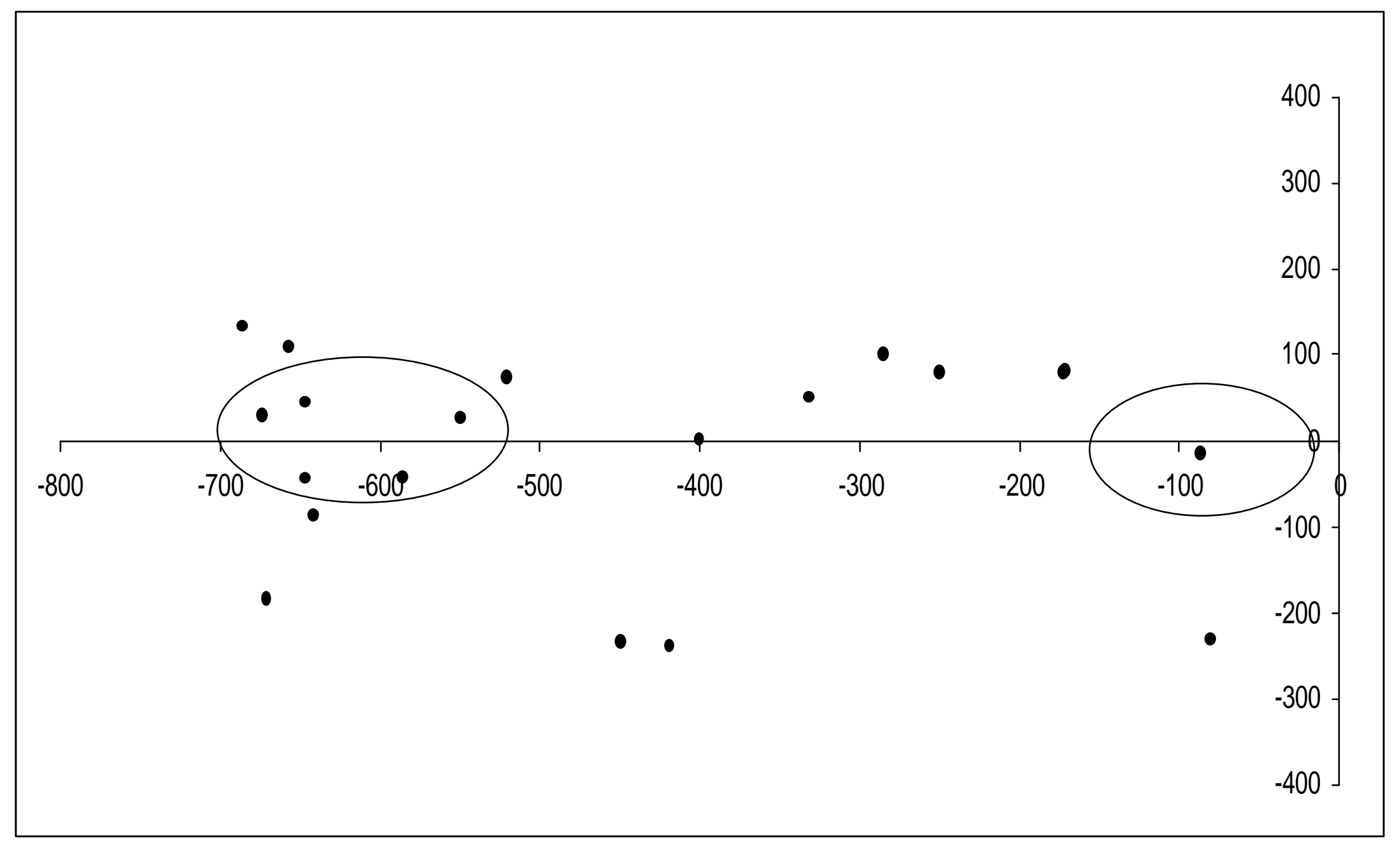

Gráfico 15: Dispersão dos afiadores em canaleta, setores III a VI. Nas elipses, áreas de concentração de artefatos. 
Soares,A.L.R. 2004 - Contribuição à Arqueologia Guarani: estudo do sítio Röpke

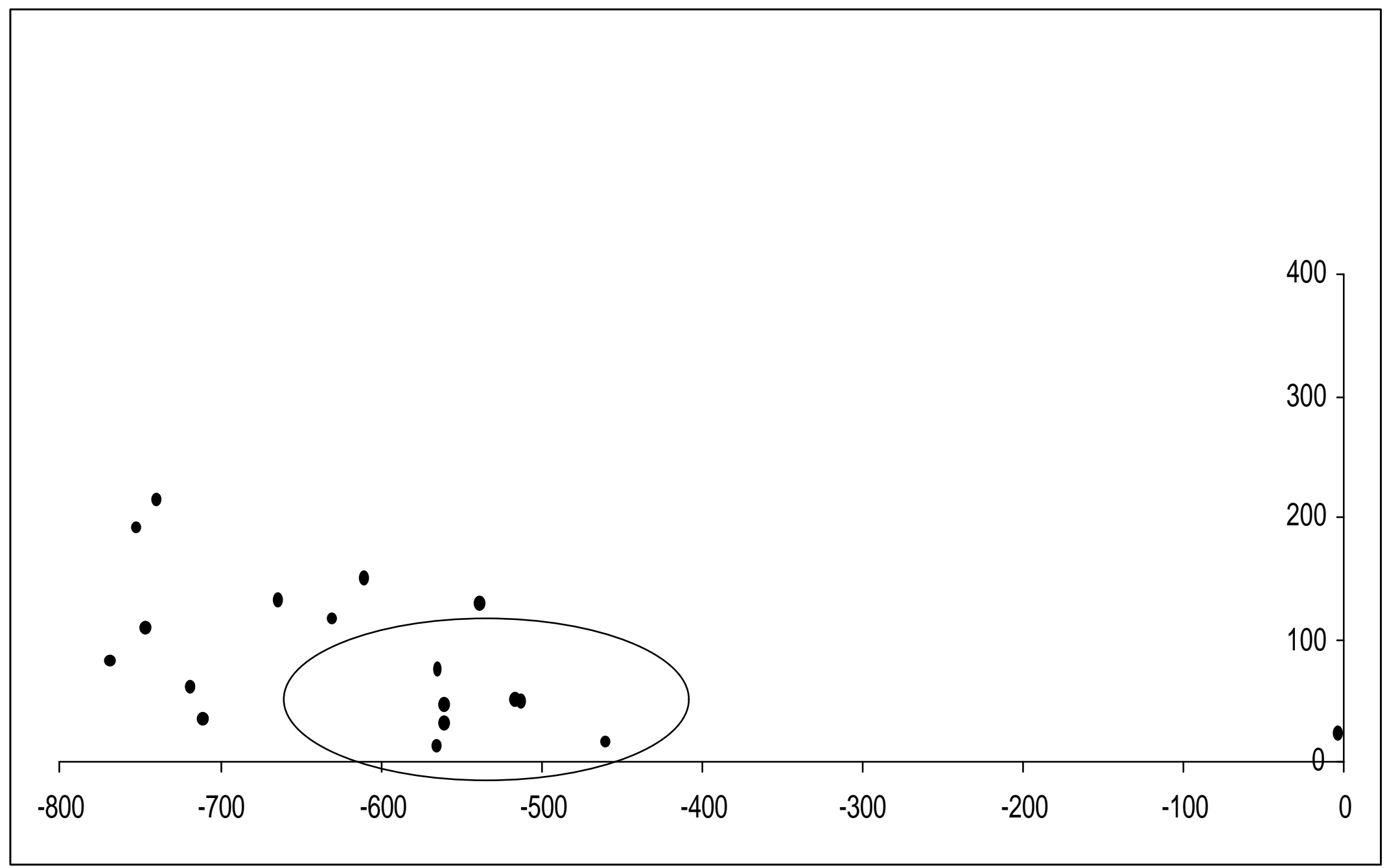

Gráfico 16: Dispersão dos blocos de arenito com sinal de polimento do setor 1. Na elipse, área de concentração de artefatos e provável localização da fogueira. 
Soares,A.L.R. 2004 - Contribuição à Arqueologia Guarani: estudo do sítio Röpke

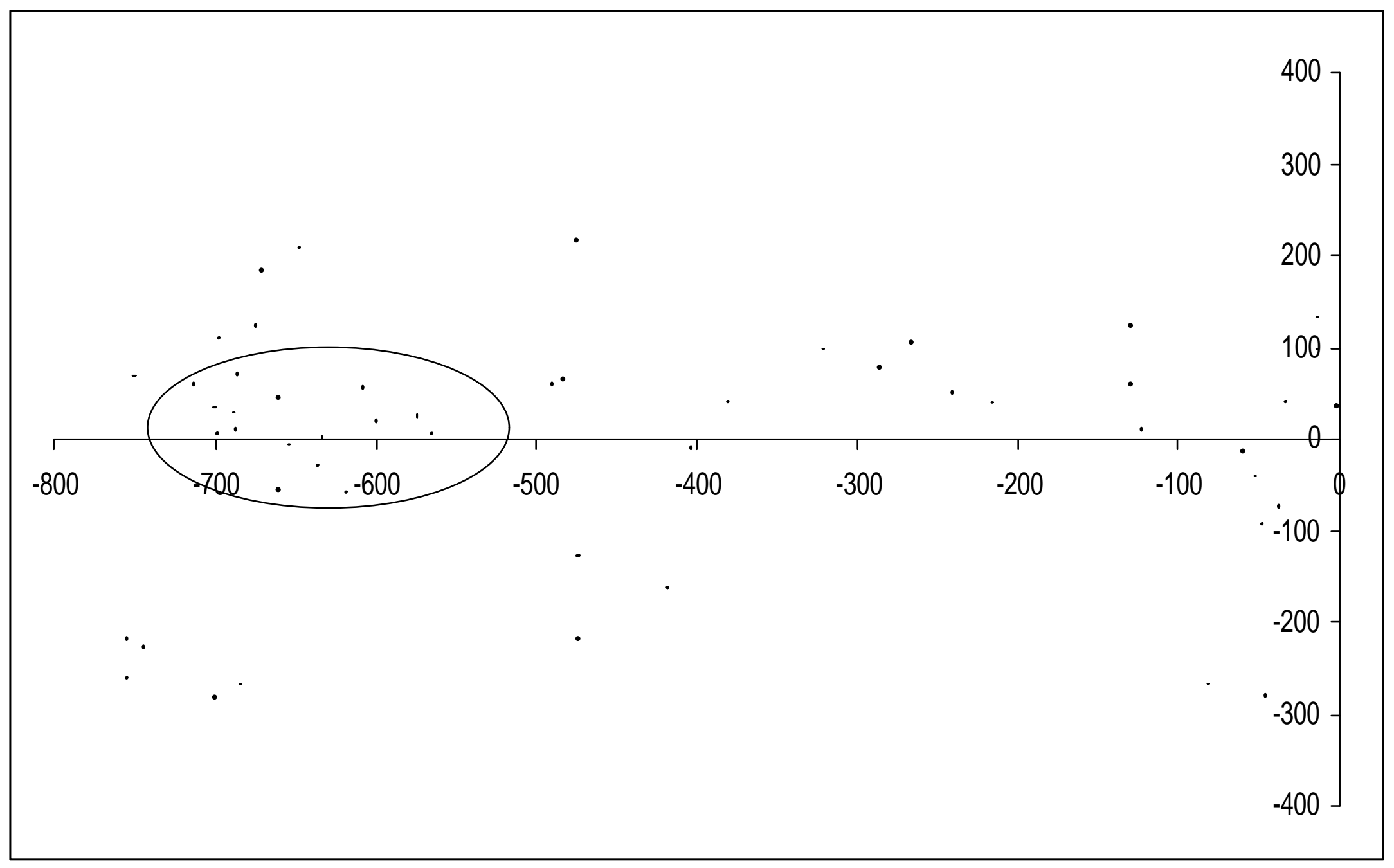

Gráfico 17 : Área de dispersão dos blocos com sinal de polimento. Na elipse, área de concentração de artefatos e provável localização da fogueira. 
Soares,A.L.R. 2004 - Contribuição à Arqueologia Guarani: estudo do sítio Röpke

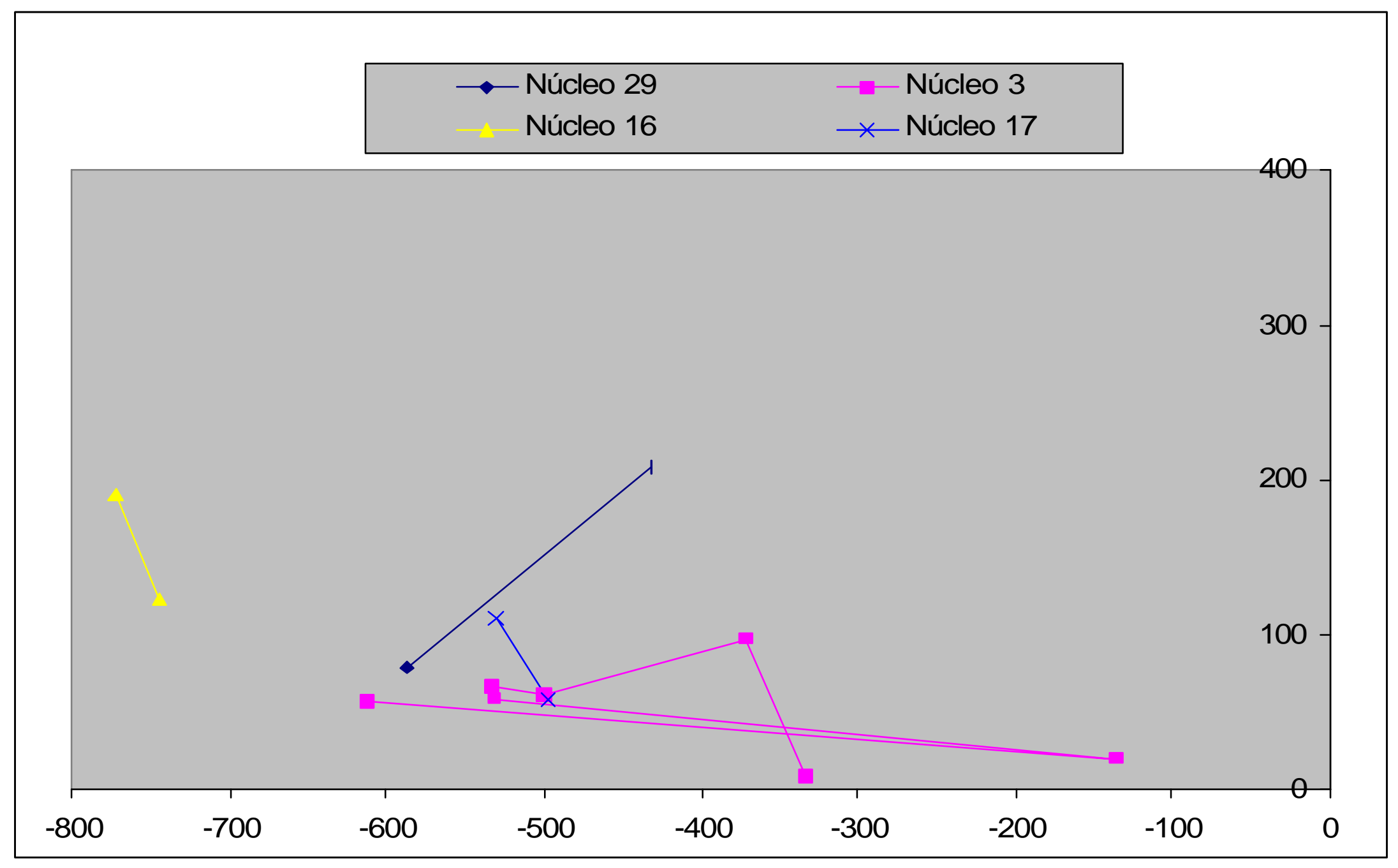

Gráfico 18 : Área de dispersão dos núcleos 3, 16, 17 e 29 no Setor 1. 
Soares,A.L.R. 2004 - Contribuição à Arqueologia Guarani: estudo do sítio Röpke

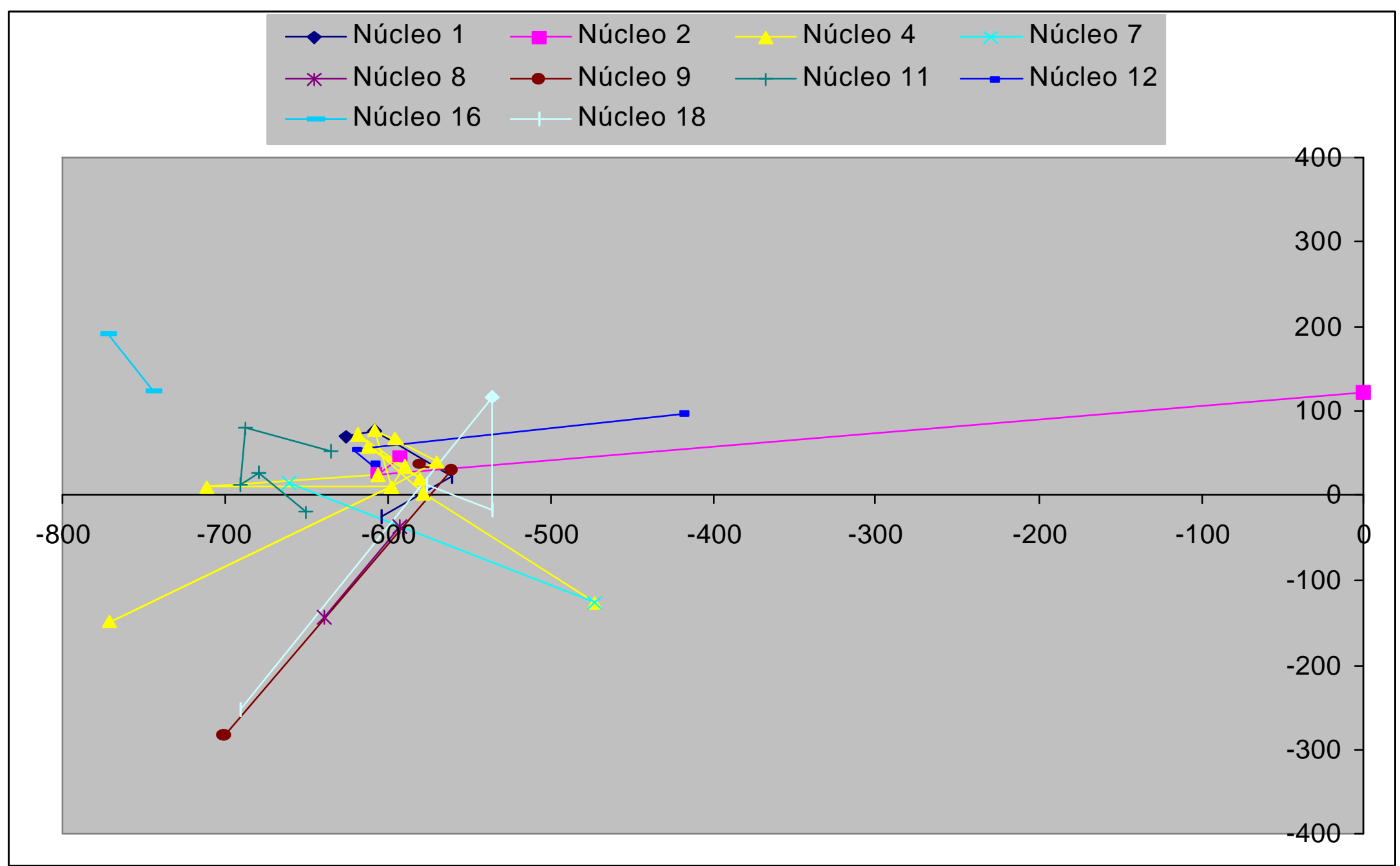

Gráfico 19 : Dispersão dos núcleos nos Setores III a VI. 
Soares,A.L.R. 2004 - Contribuição à Arqueologia Guarani: estudo do sítio Röpke

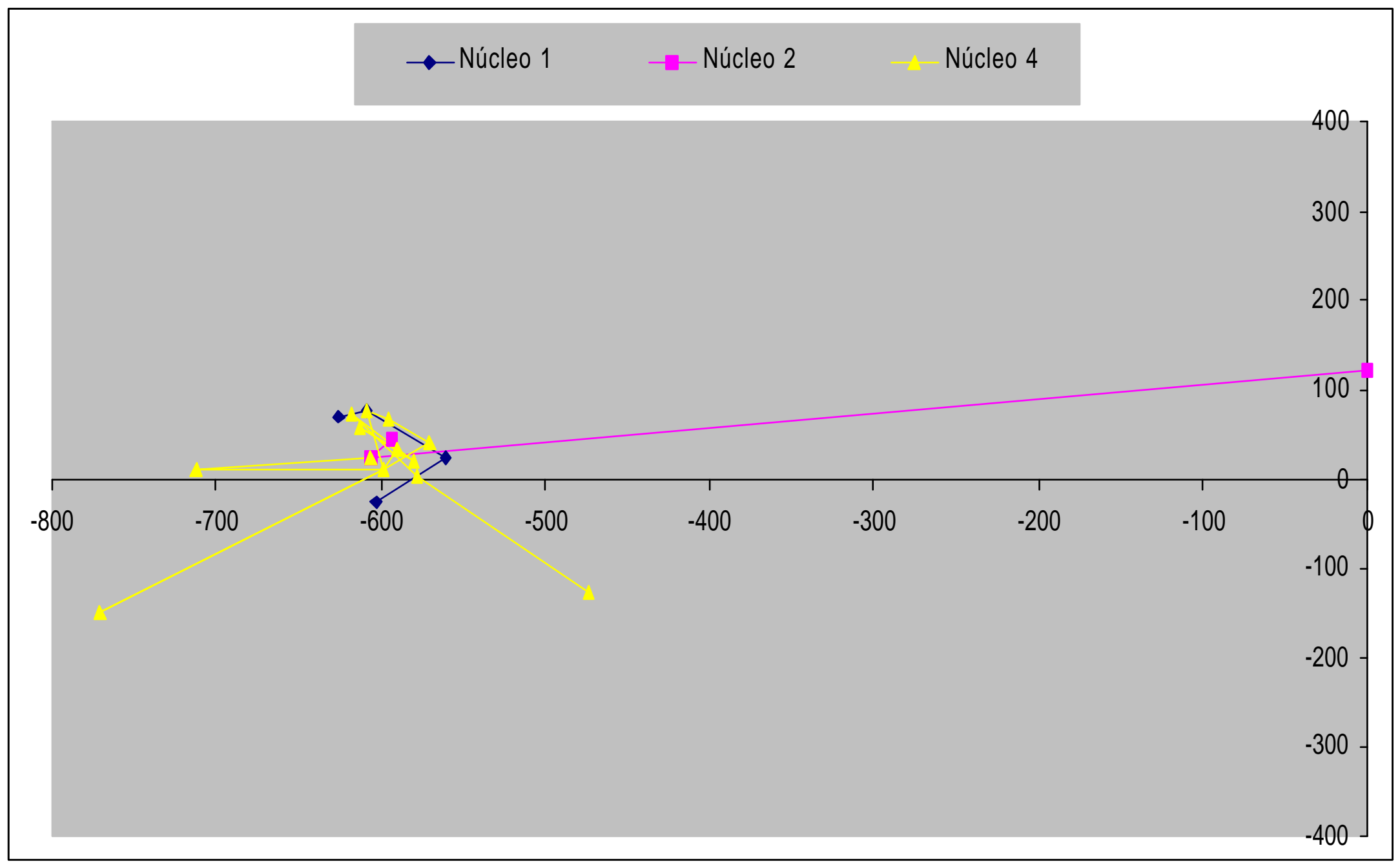

Gráfico 20 : Dispersão dos núcleos 1, 2 e 4 nos Setores III a VI. 
Soares,A.L.R. 2004 - Contribuição à Arqueologia Guarani: estudo do sítio Röpke

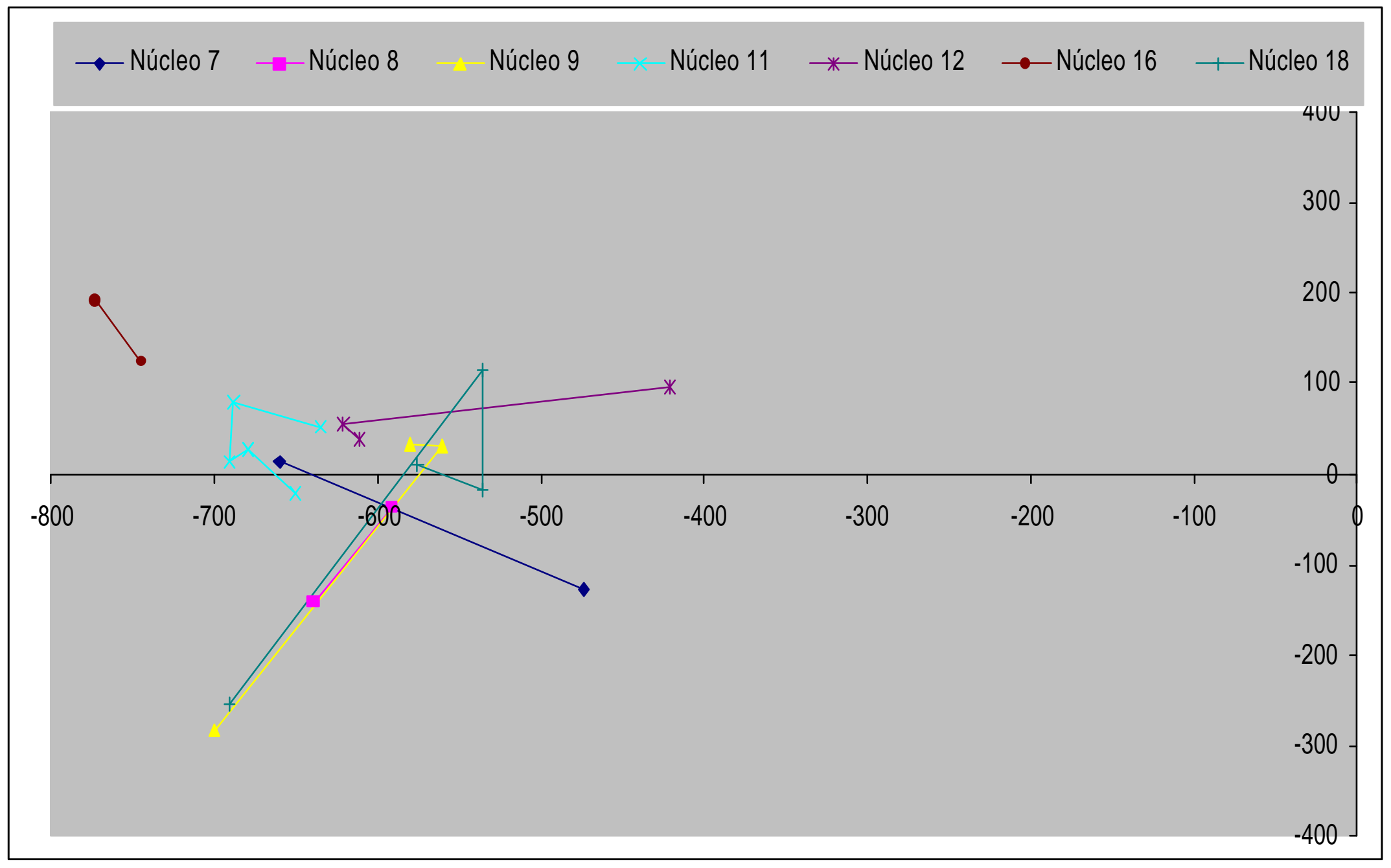

Gráfico 21 : Dispersão dos núcleos 7 a 18 nos Setores III a VI. 
Soares,A.L.R. 2004 - Contribuição à Arqueologia Guarani: estudo do sítio Röpke

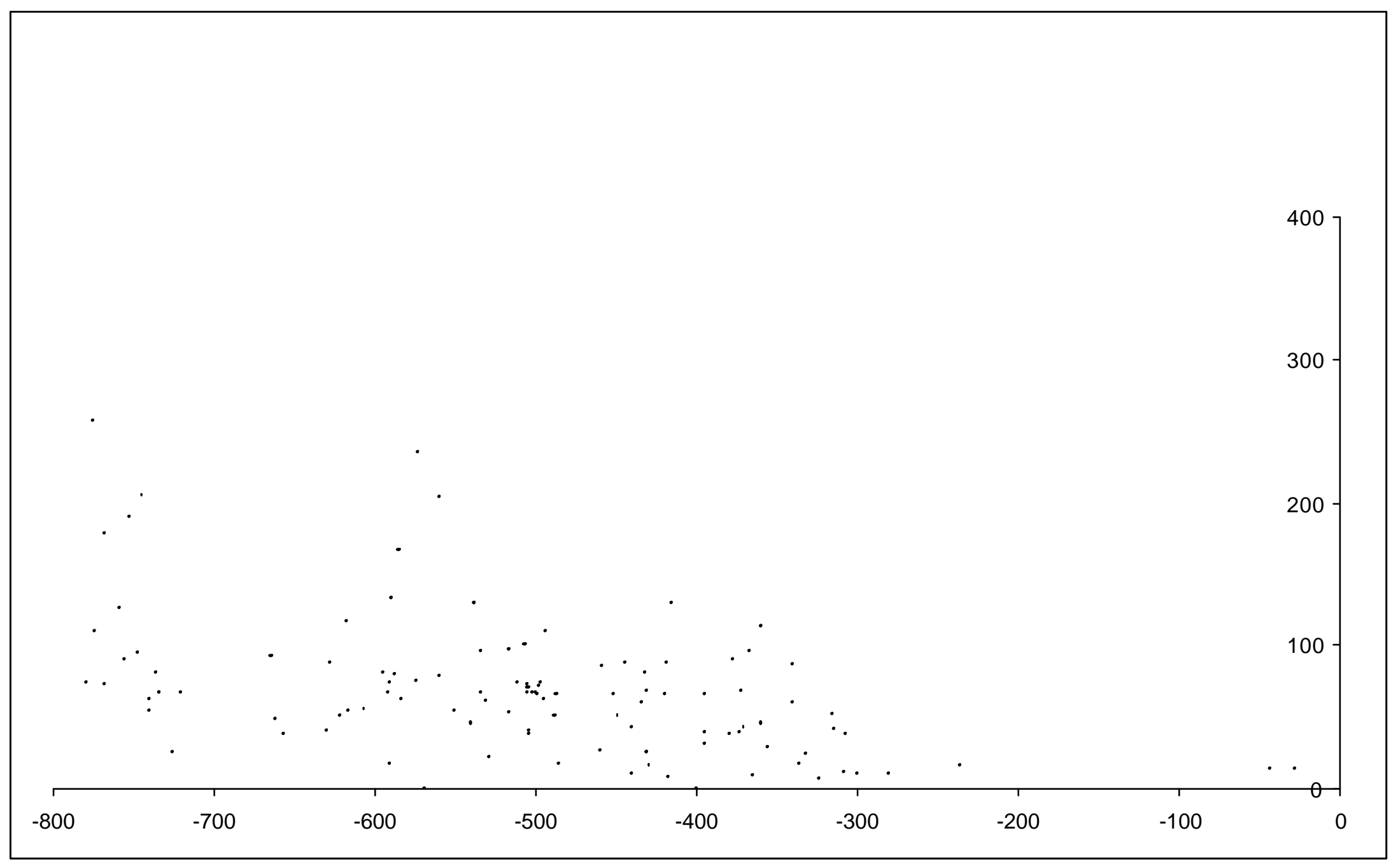

Gráfico 22 : Dispersão dos fragmentos de calcedônia com sinais de queima. Setor 1. 
Soares,A.L.R. 2004 - Contribuição à Arqueologia Guarani: estudo do sítio Röpke

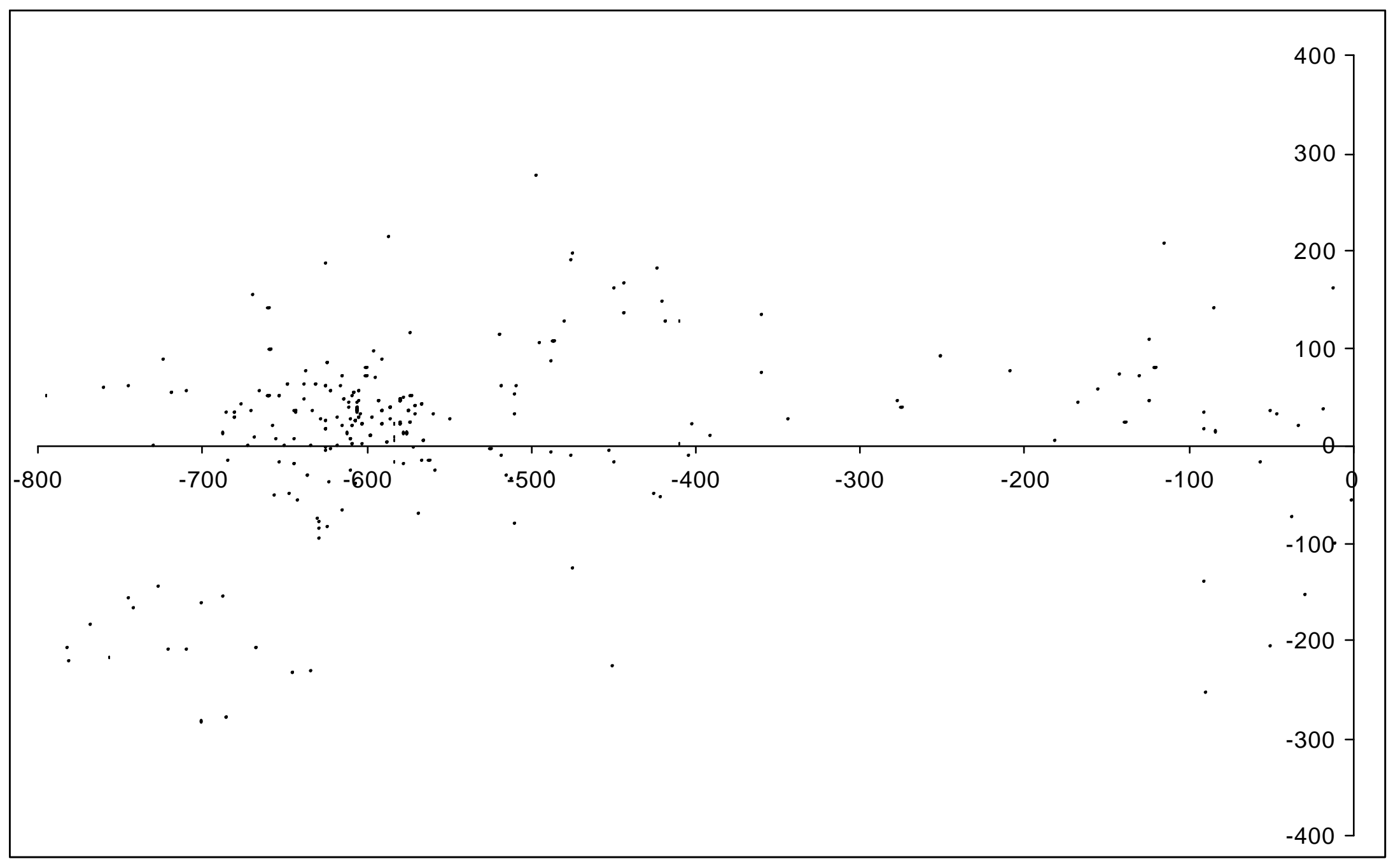

Gráfico 23 : Dispersão dos fragmentos de calcedônia com sinais de queima. Setores III a VI. 
Soares,A.L.R. 2004 - Contribuição à Arqueologia Guarani: estudo do sítio Röpke

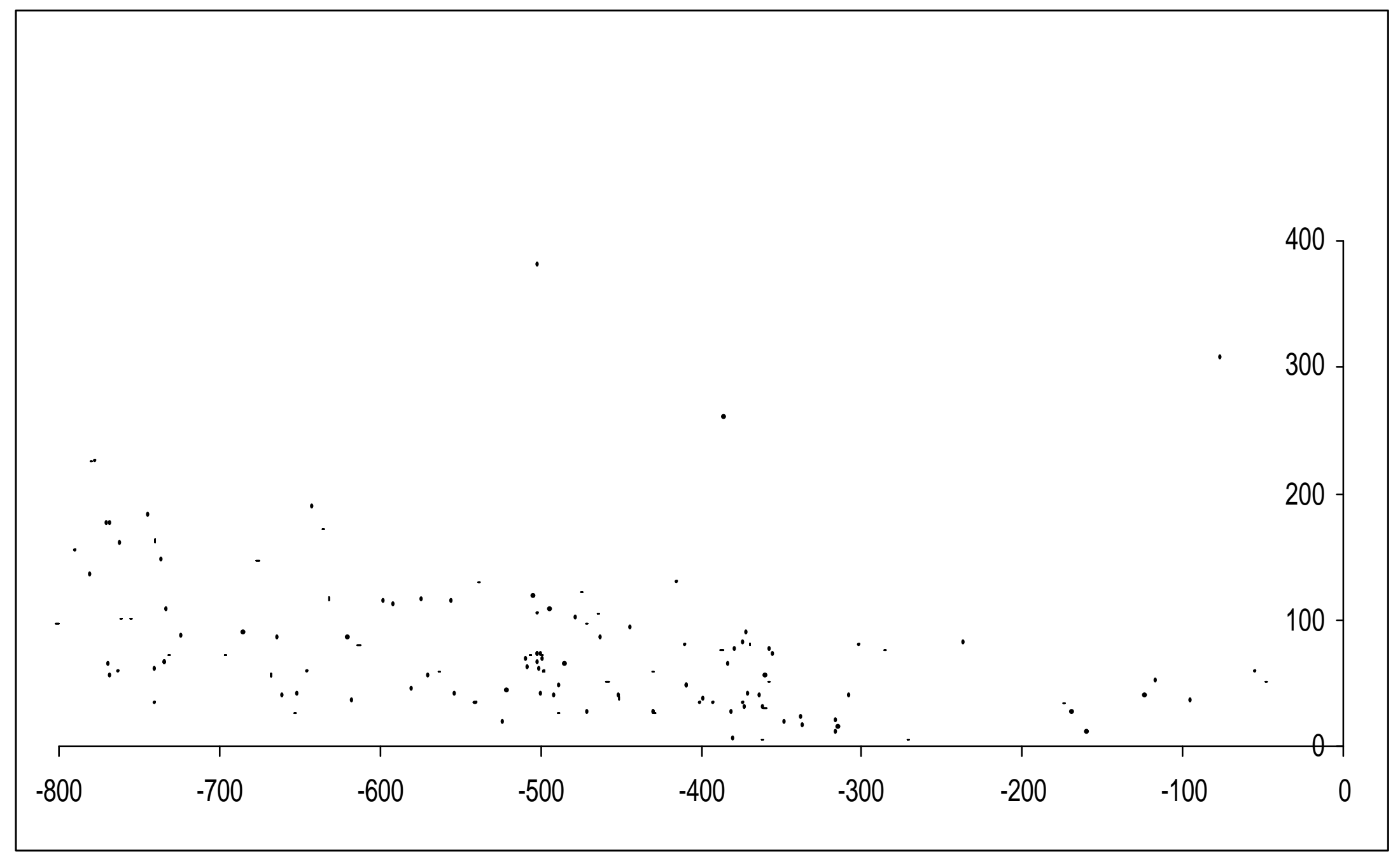

Gráfico 24 : Dispersão dos fragmentos de calcedônia sem sinais de queima. Setor 1. 
Soares,A.L.R. 2004 - Contribuição à Arqueologia Guarani: estudo do sítio Röpke

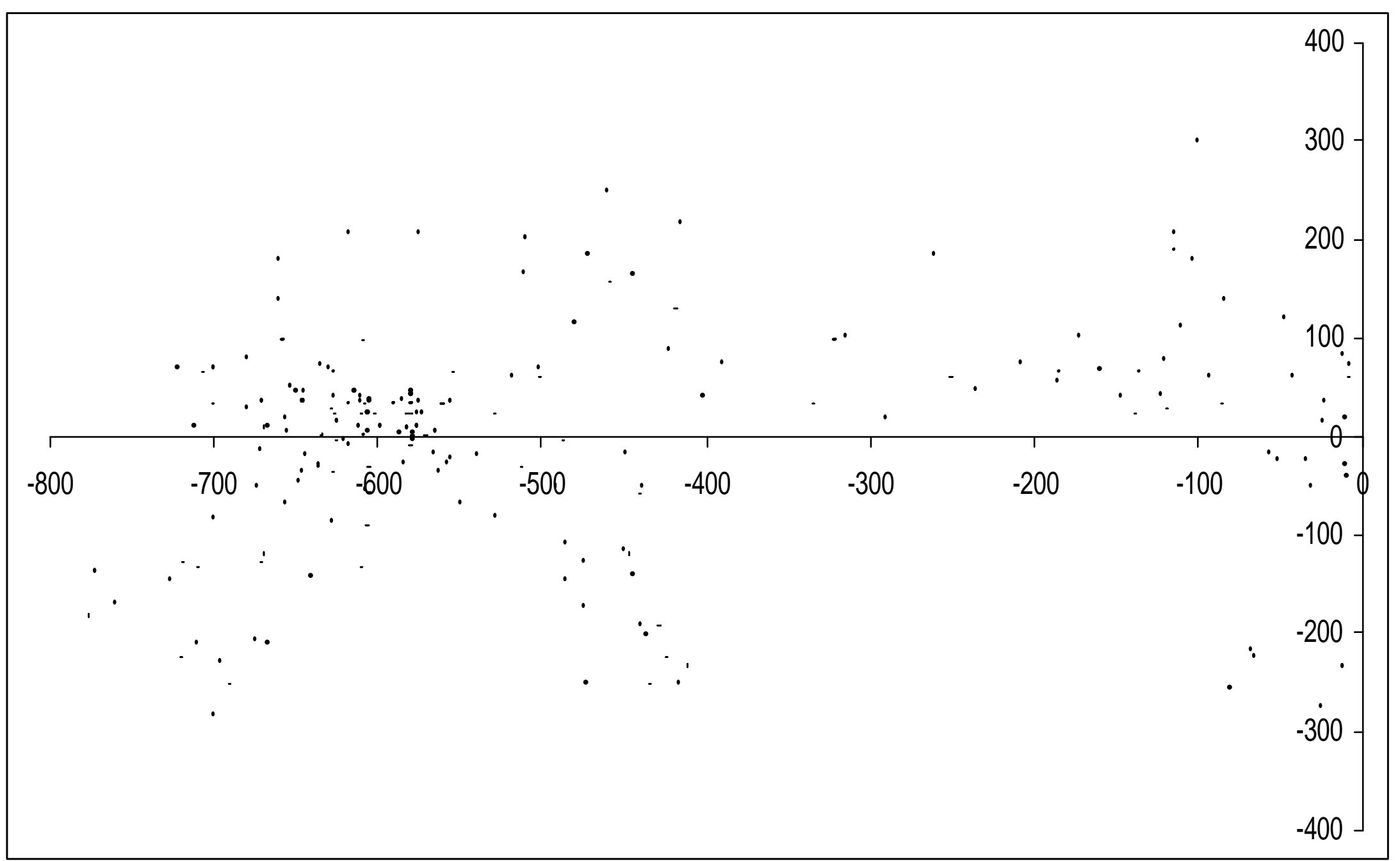

Gráfico 25 : Dispersão dos fragmentos de calcedônia sem sinais de queima. Setores III a VI. 
Soares,A.L.R. 2004 - Contribuição à Arqueologia Guarani: estudo do sítio Röpke

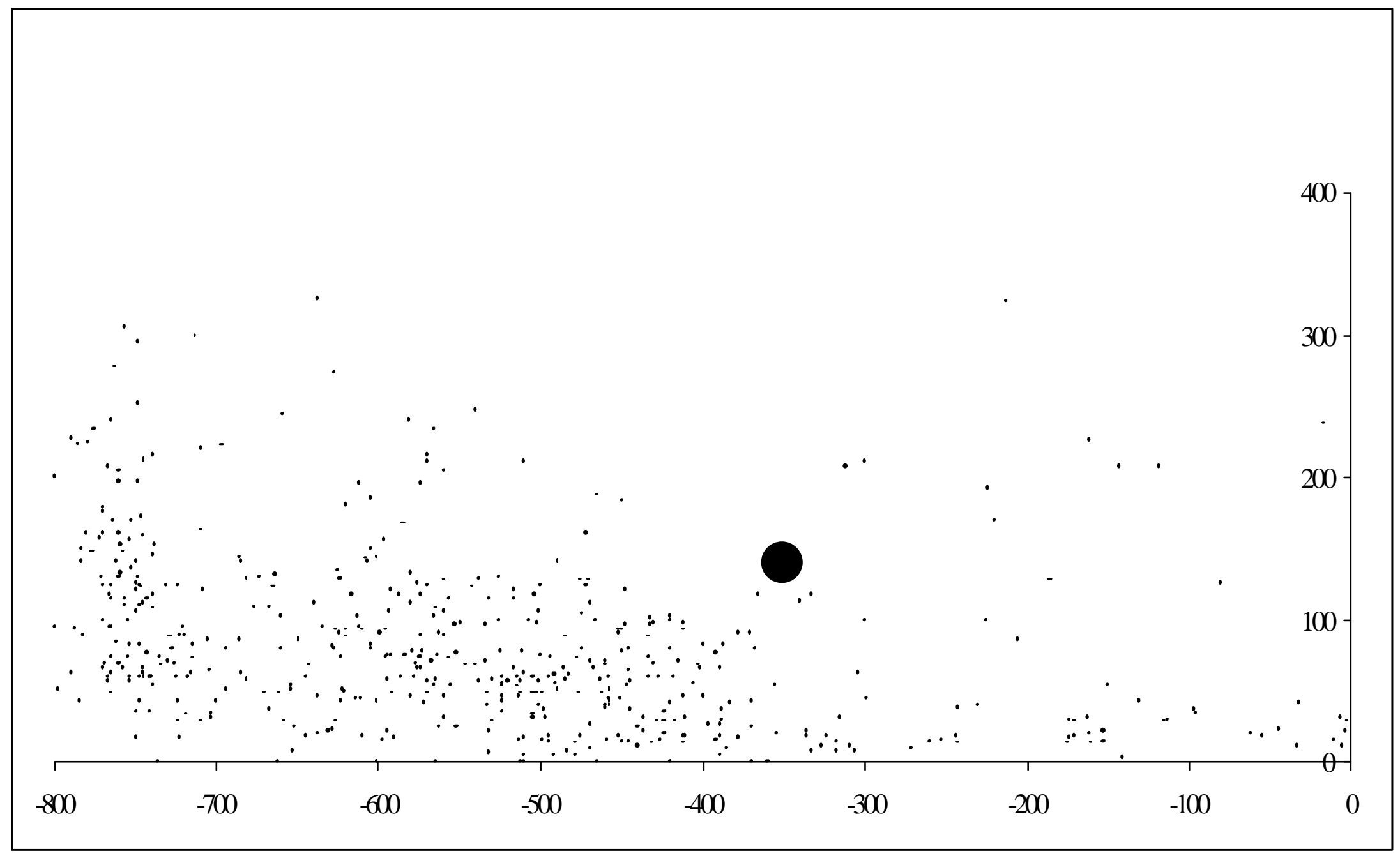

Gráfico 26: Dispersão de todos os fragmentos cerâmicos do setor 1. No círculo, negativo de esteio. 
Soares,A.L.R. 2004 - Contribuição à Arqueologia Guarani: estudo do sítio Röpke

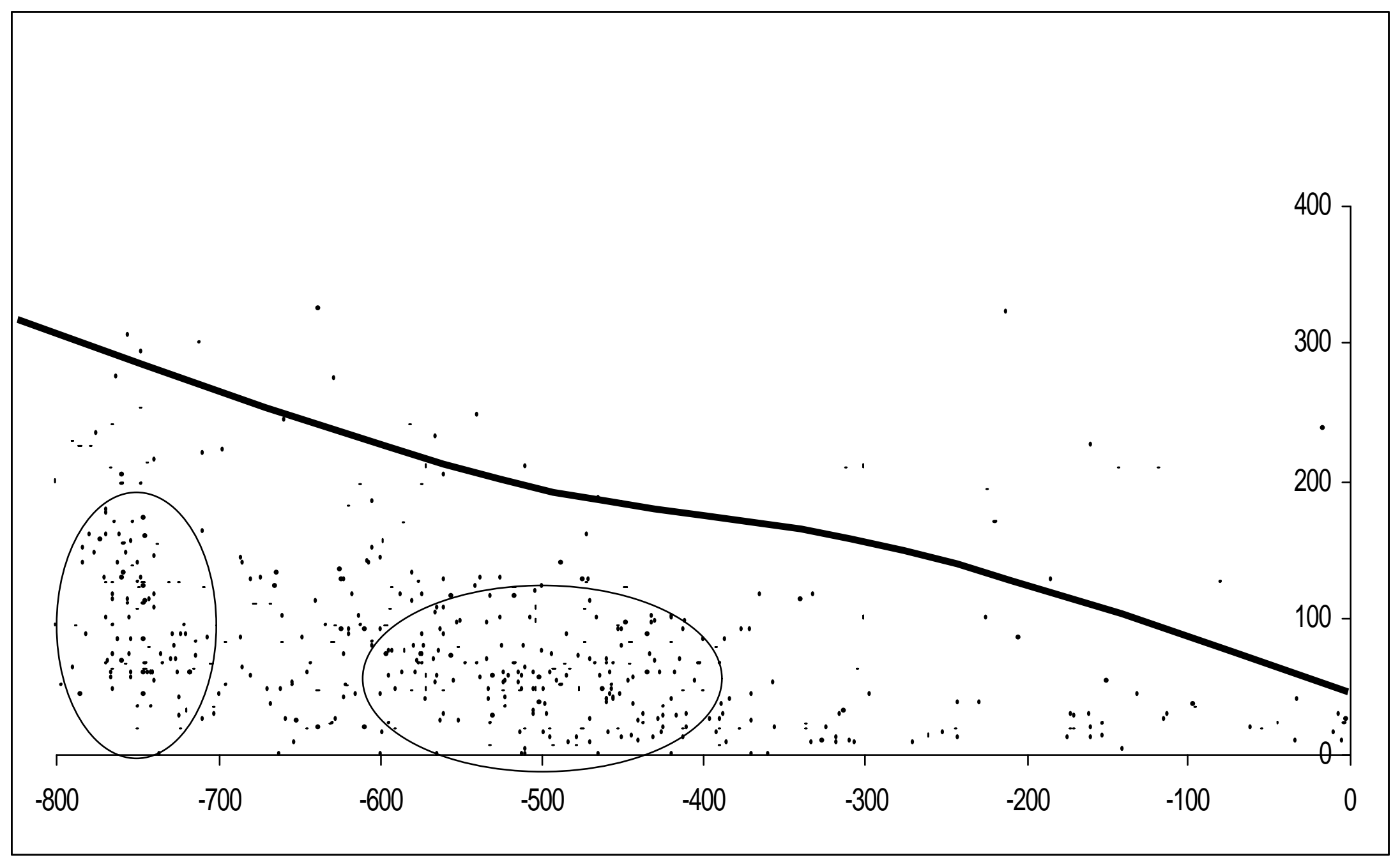

Gráfico 27: Dispersão de todos os fragmentos cerâmicos do setor 1. Na elipse, área de concentração de artefatos. Na linha contínua, limite da área de circulação. 
Soares,A.L.R. 2004 - Contribuição à Arqueologia Guarani: estudo do sítio Röpke

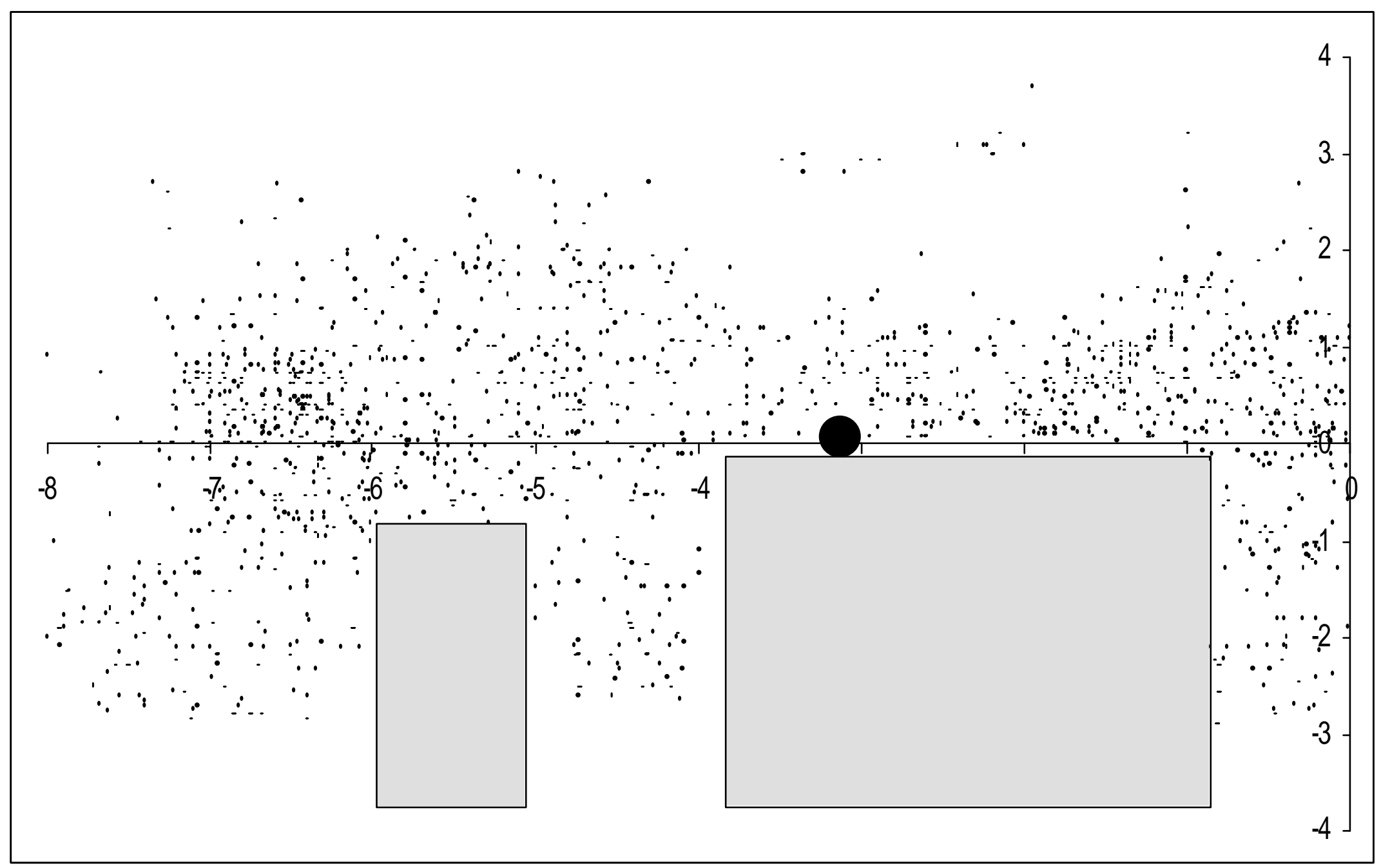

Gráfico 28: Dispersão de todos os fragmentos cerâmicos dos setores III, IV, V e VI. No círculo preto, negativo de esteio. 
Soares,A.L.R. 2004 - Contribuição à Arqueologia Guarani: estudo do sítio Röpke

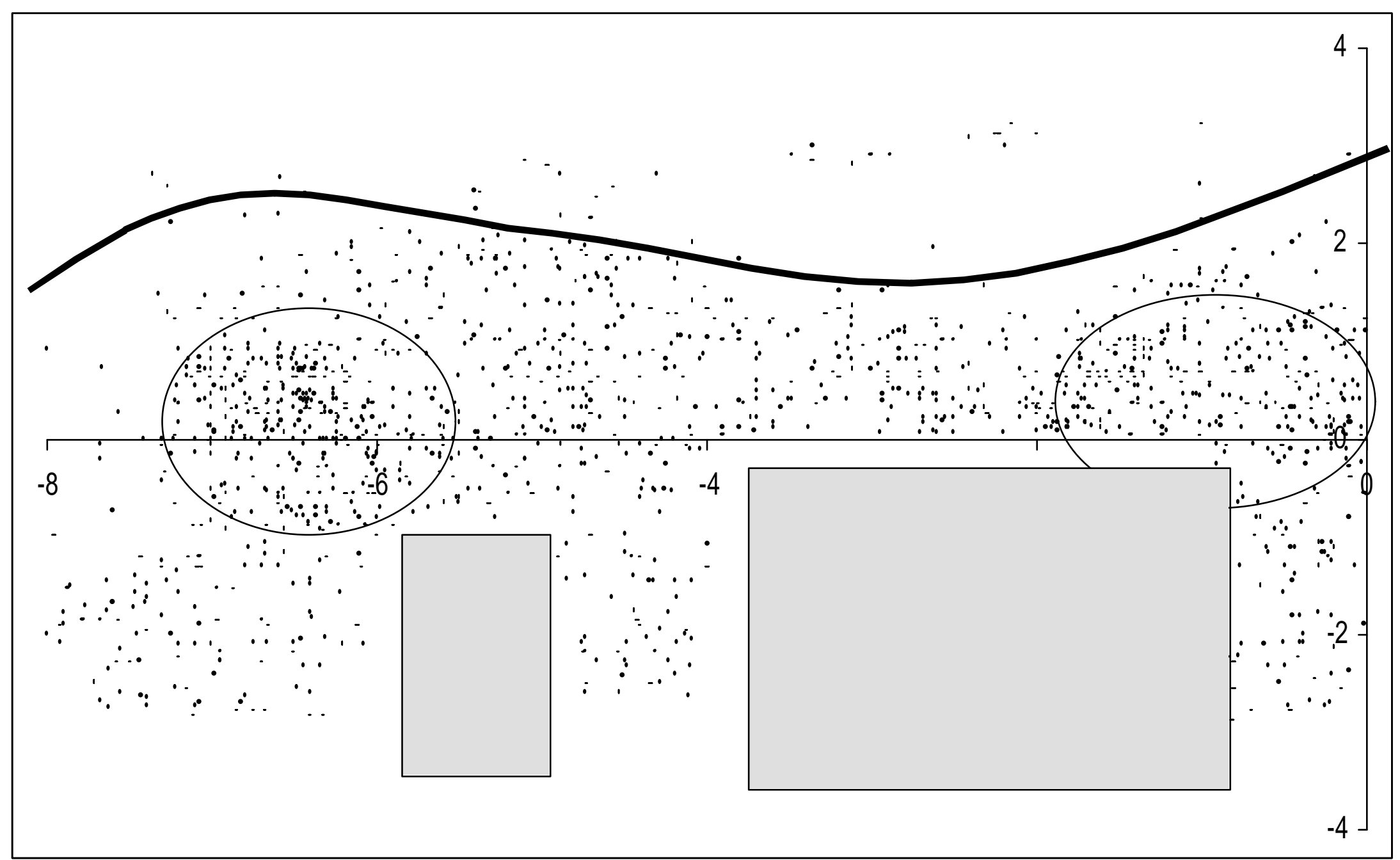

Gráfico 29: Dispersão de toda a cerâmica nos setores III, IV, V e VI. Na elipse, área de concentração de artefatos. Na linha contínua, limite da área de circulação. 
Soares,A.L.R. 2004 - Contribuição à Arqueologia Guarani: estudo do sítio Röpke

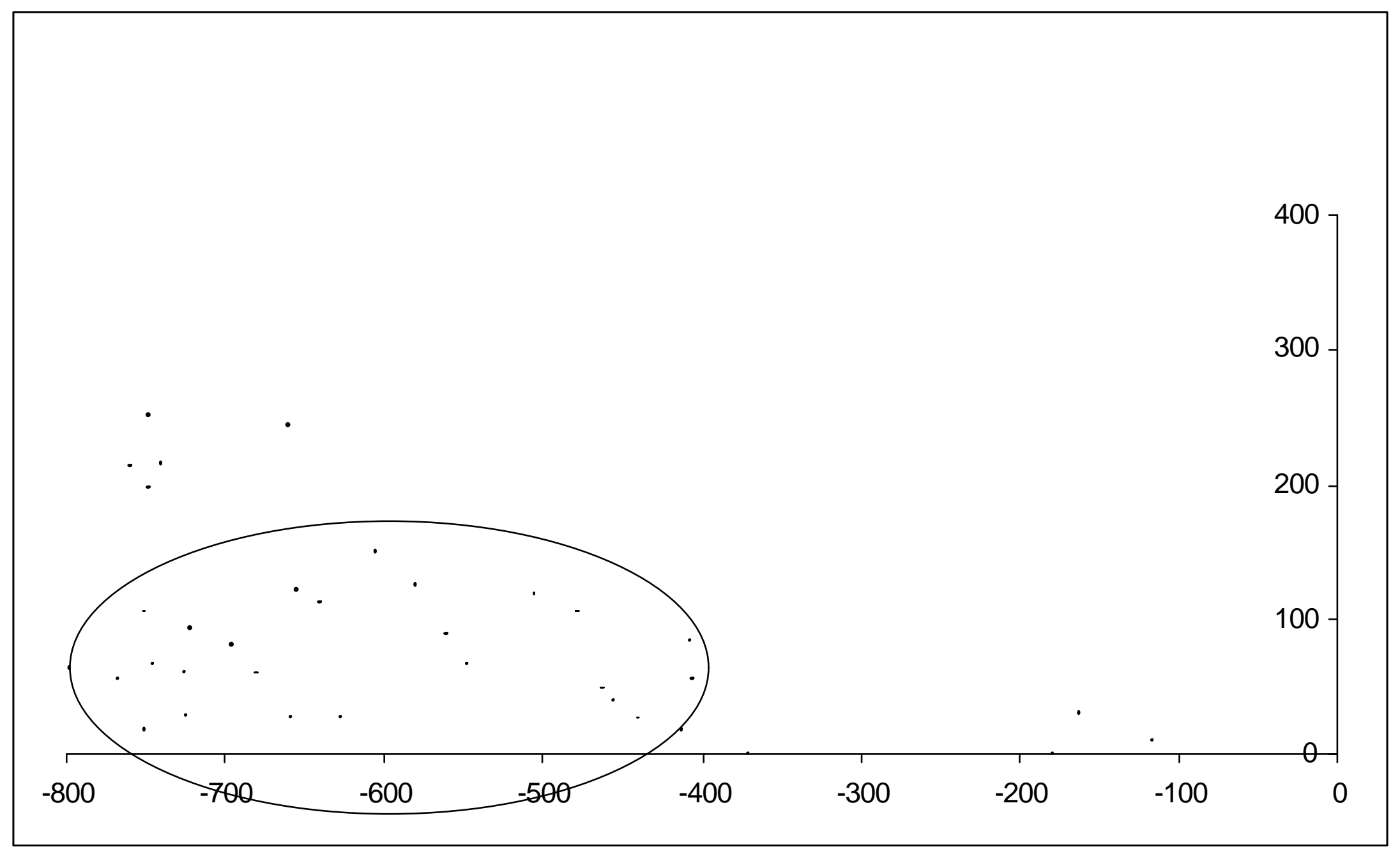

Gráfico 30 : Dispersão da cerâmica corrugada e corrugada-ungulada no setor 1. A dispersão aproxima-se da área considerada de fogueira. 
Soares,A.L.R. 2004 - Contribuição à Arqueologia Guarani: estudo do sítio Röpke

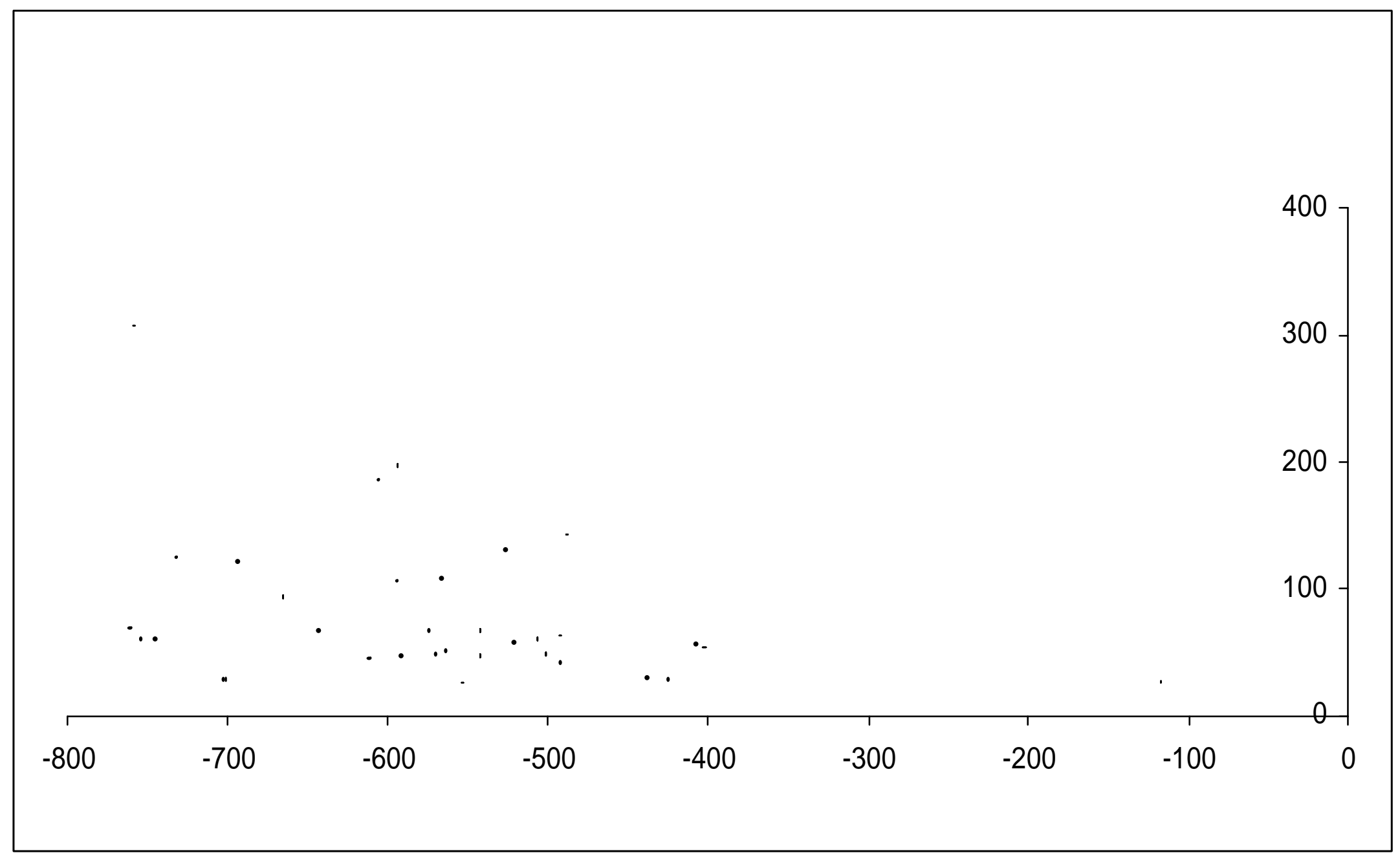

Gráfico 31: Dispersão das bordas decoradas (lisa, ungulada e pintada) no setor 1. A dispersão não se aproxima da área considerada de fogueira. 
Soares,A.L.R. 2004 - Contribuição à Arqueologia Guarani: estudo do sítio Röpke

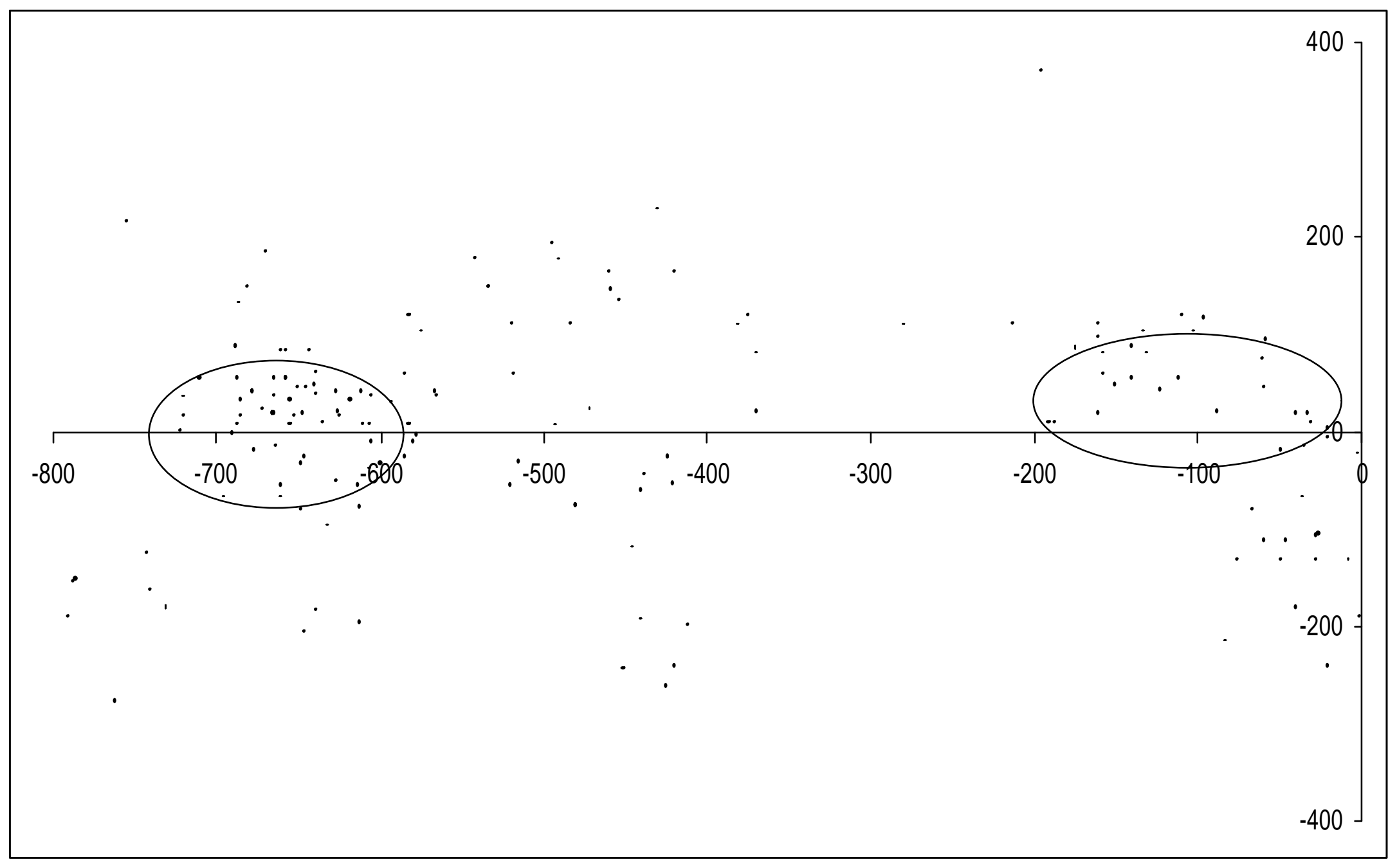

Gráfico 32 : Dispersão da cerâmica corrugada e corrugada-ungulada nos setores III, IV, V e VI. A dispersão aproxima-se da área considerada de fogueira. 
Soares,A.L.R. 2004 - Contribuição à Arqueologia Guarani: estudo do sítio Röpke

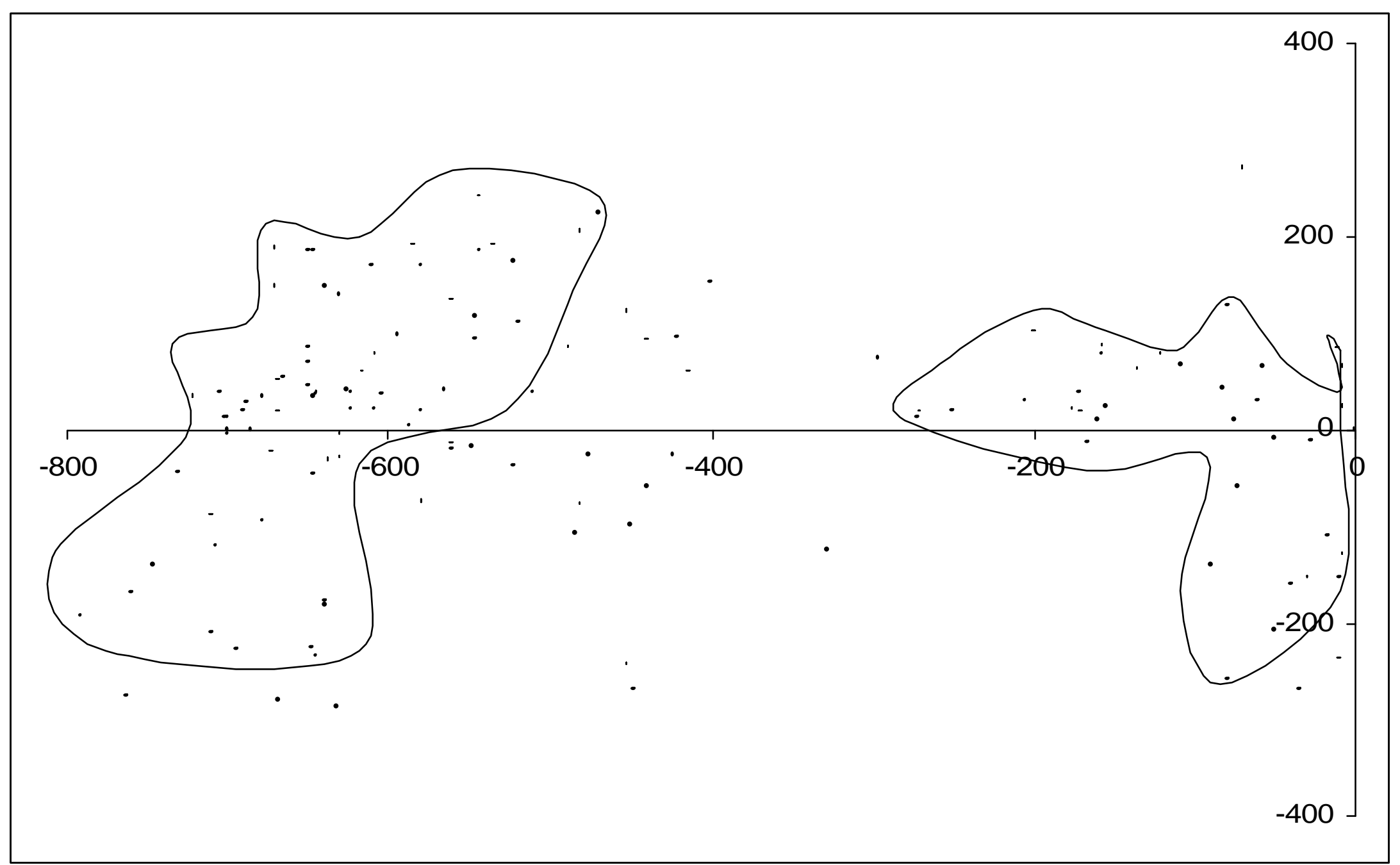

Gráfico 33 : Dispersão da cerâmica decorada (lisa, ungulada e pintada) nos setores III, IV, V e VI. A dispersão da cerâmica afasta-se da área considerada de fogueira. 


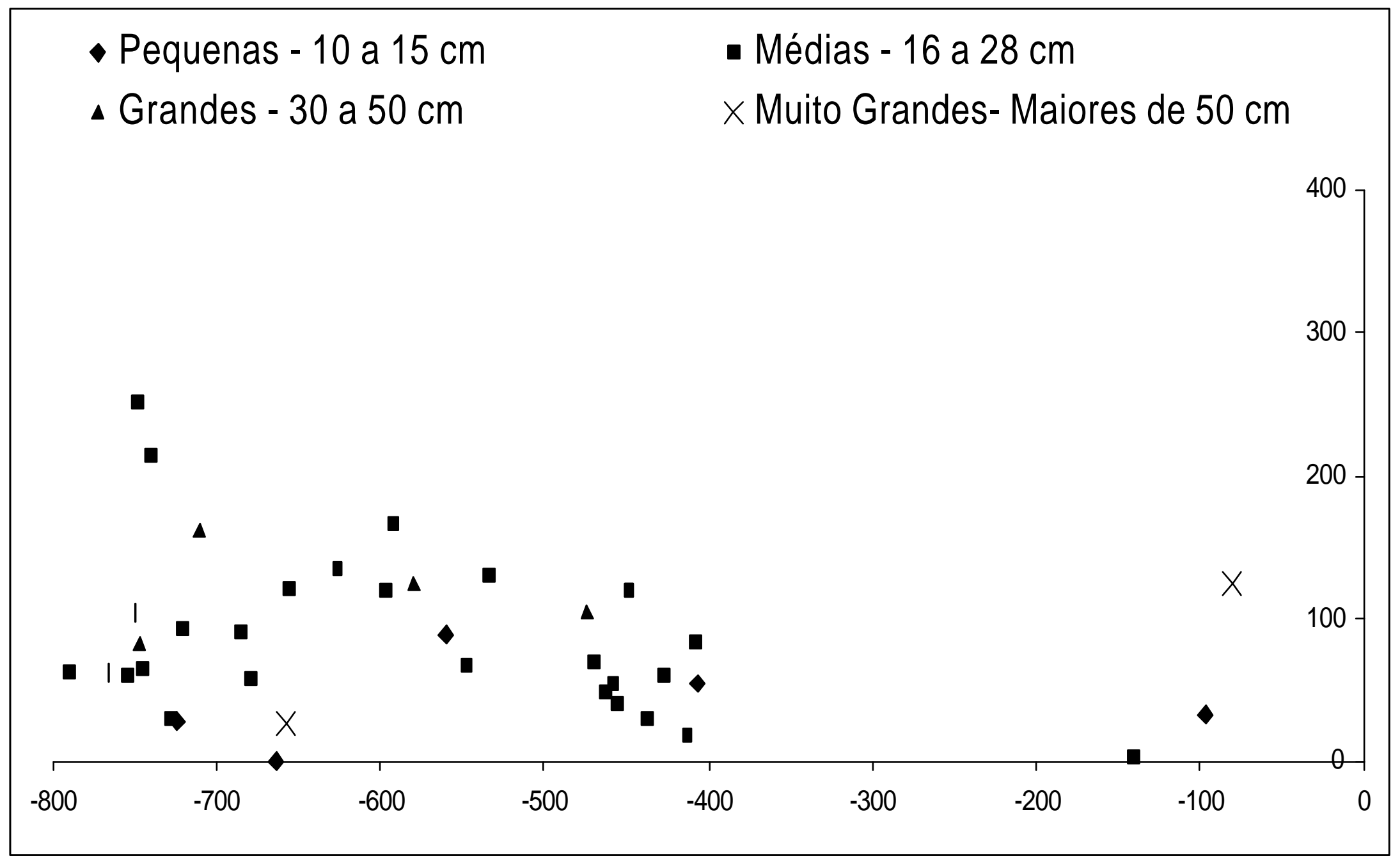

Gráfico 34 : Dispersão dos fragmentos de borda de panelas no Setor 1. Observe-se que todas as dimensões estão presentes, contribuindo para a hipótese de uma família nuclear. 


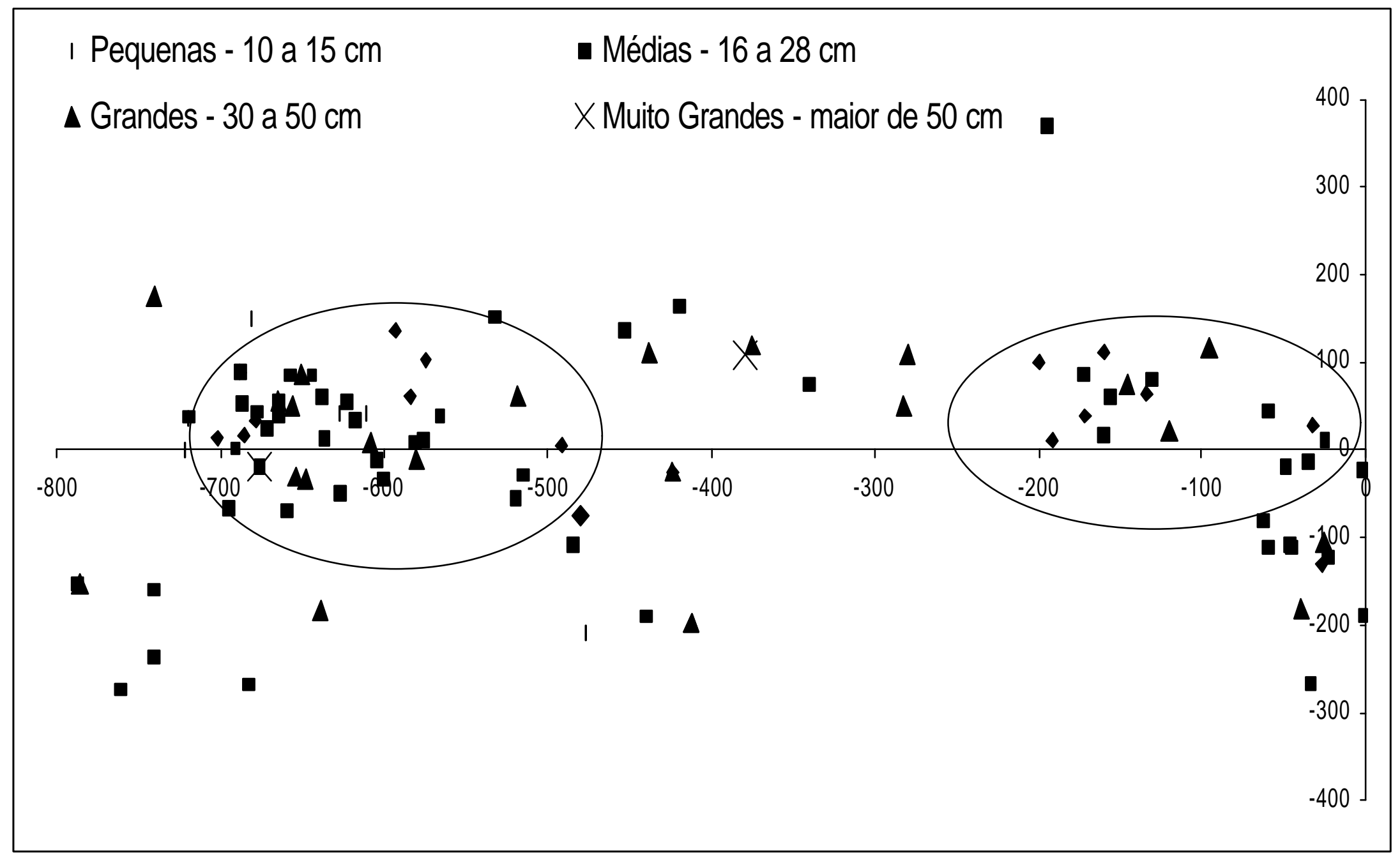

Gráfico 35 : Dispersão dos fragmentos de borda de panelas nos setores III a VI. 


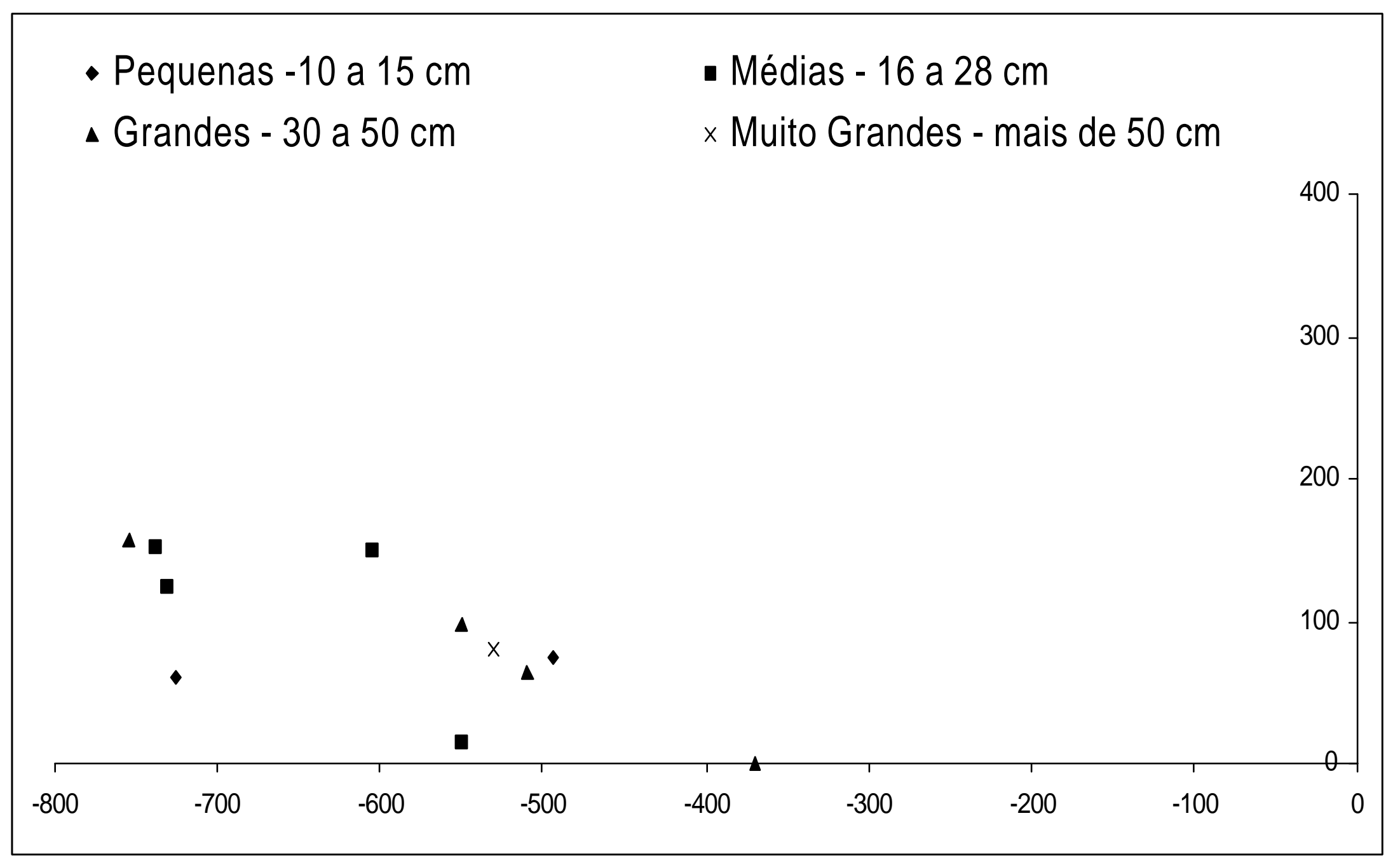

Gráfico 36 : Dispersão dos fragmentos de borda de tigelas de comer no Setor 1. 


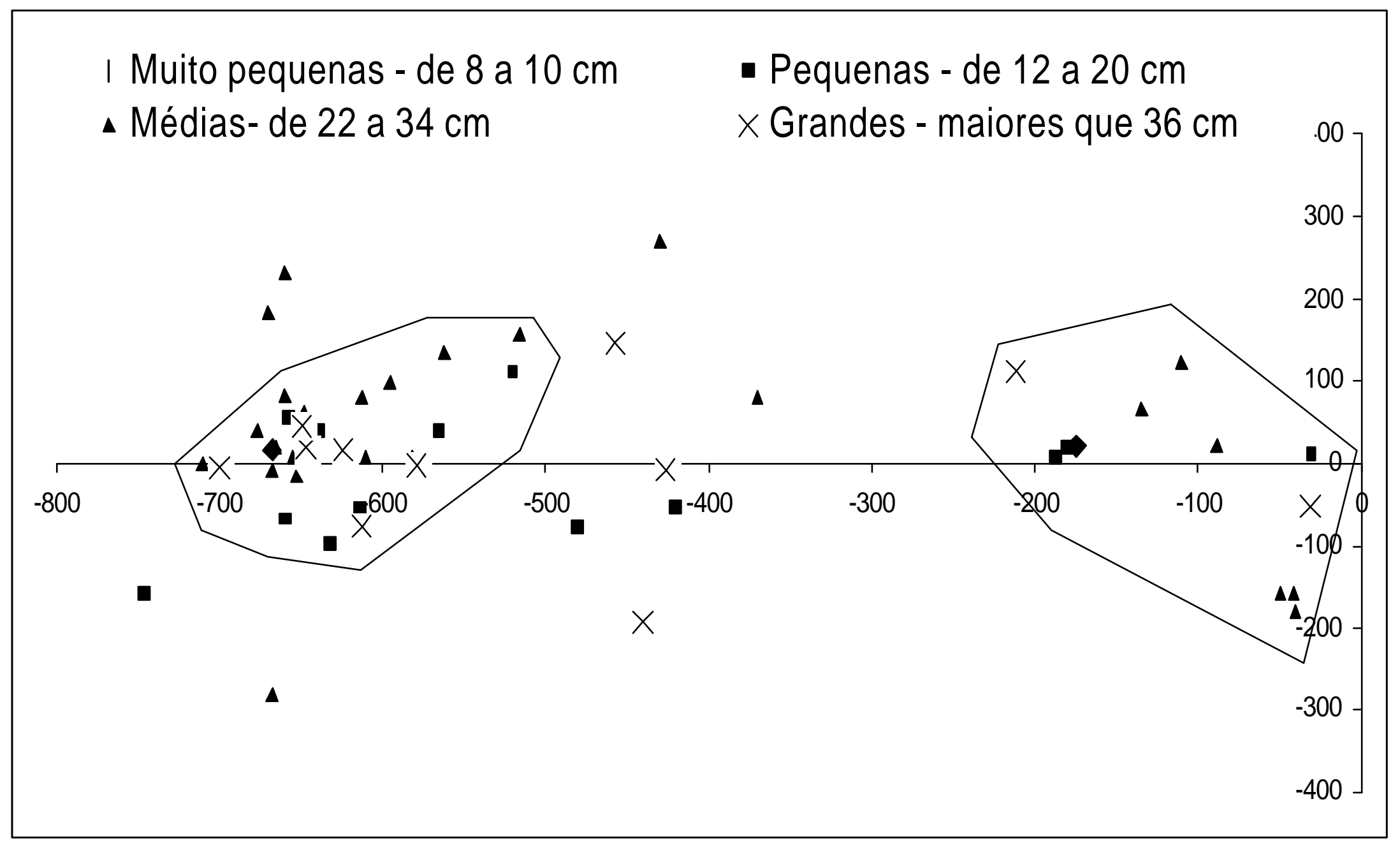

Gráfico 37: Dispersão dos fragmentos de borda de tigelas de comer nos setores III a VI. Nas áreas assinaladas, encontramse todas as dimensões, contribuindo para a idéia de duas concentrações, ou famílias nucleares. 


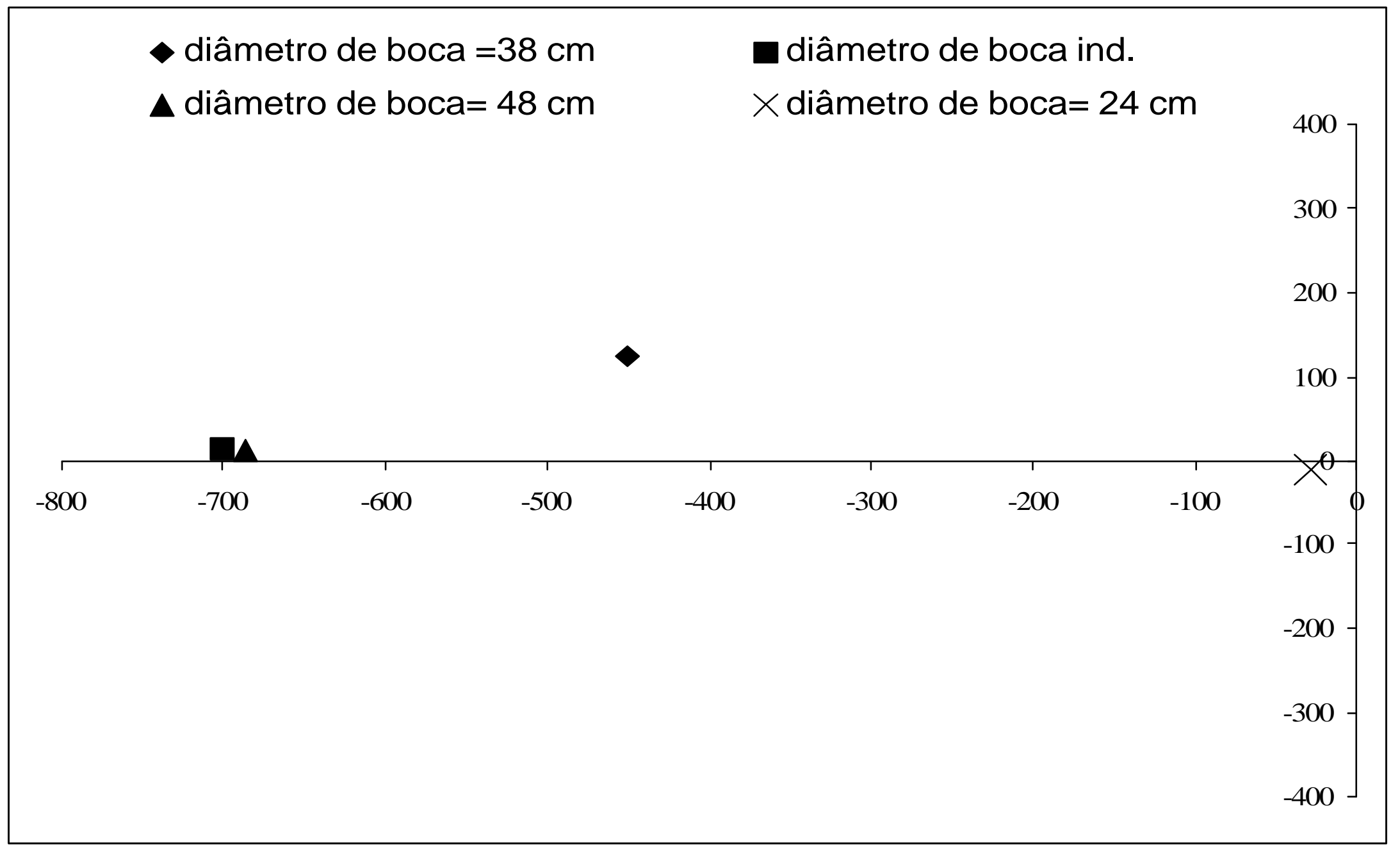

Gráfico 38 : Dispersão dos fragmentos de borda de talhas nos setores III a VI. 


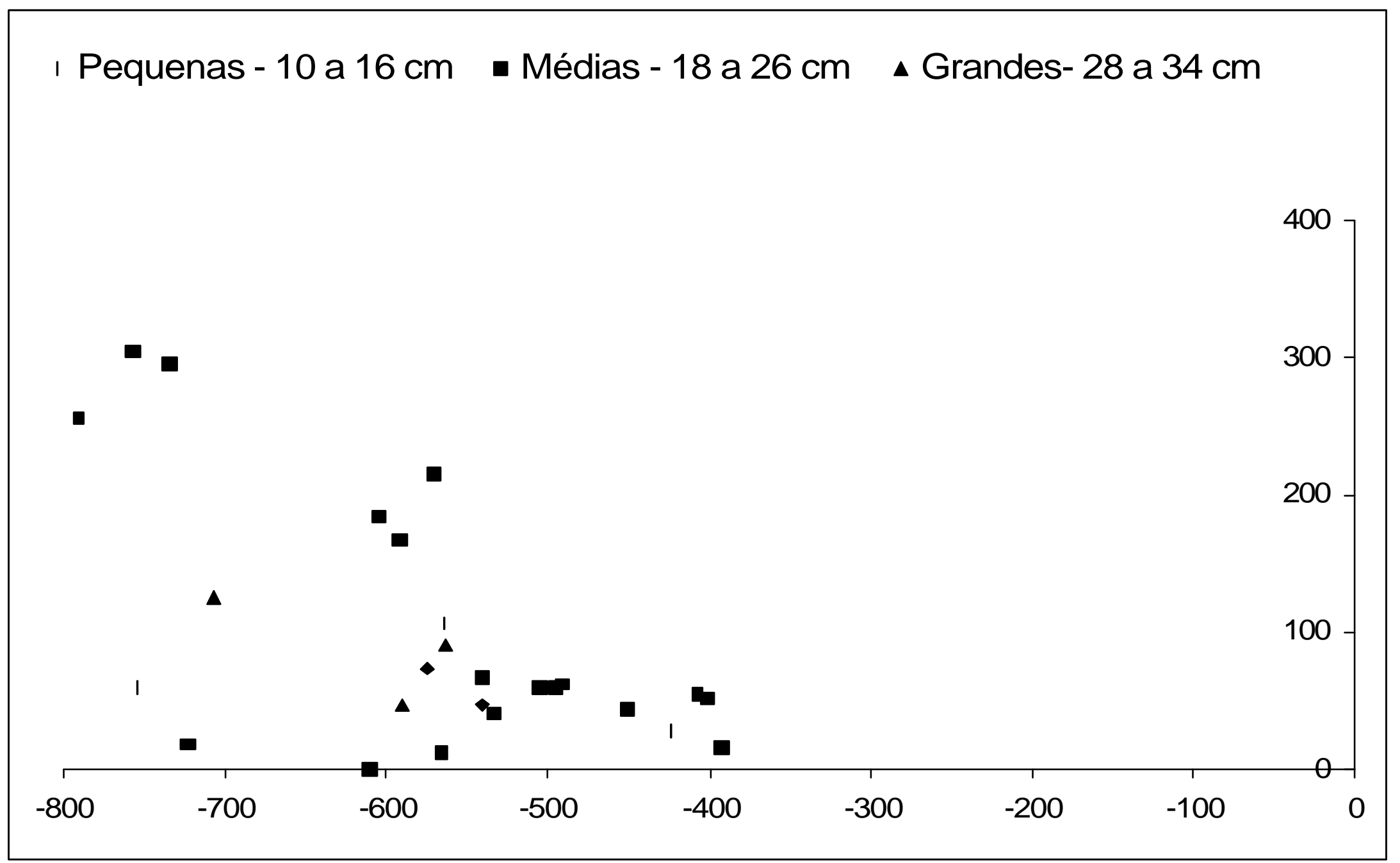

Gráfico 39 : Dispersão dos fragmentos de borda de tigelas de beber no setor 1. 


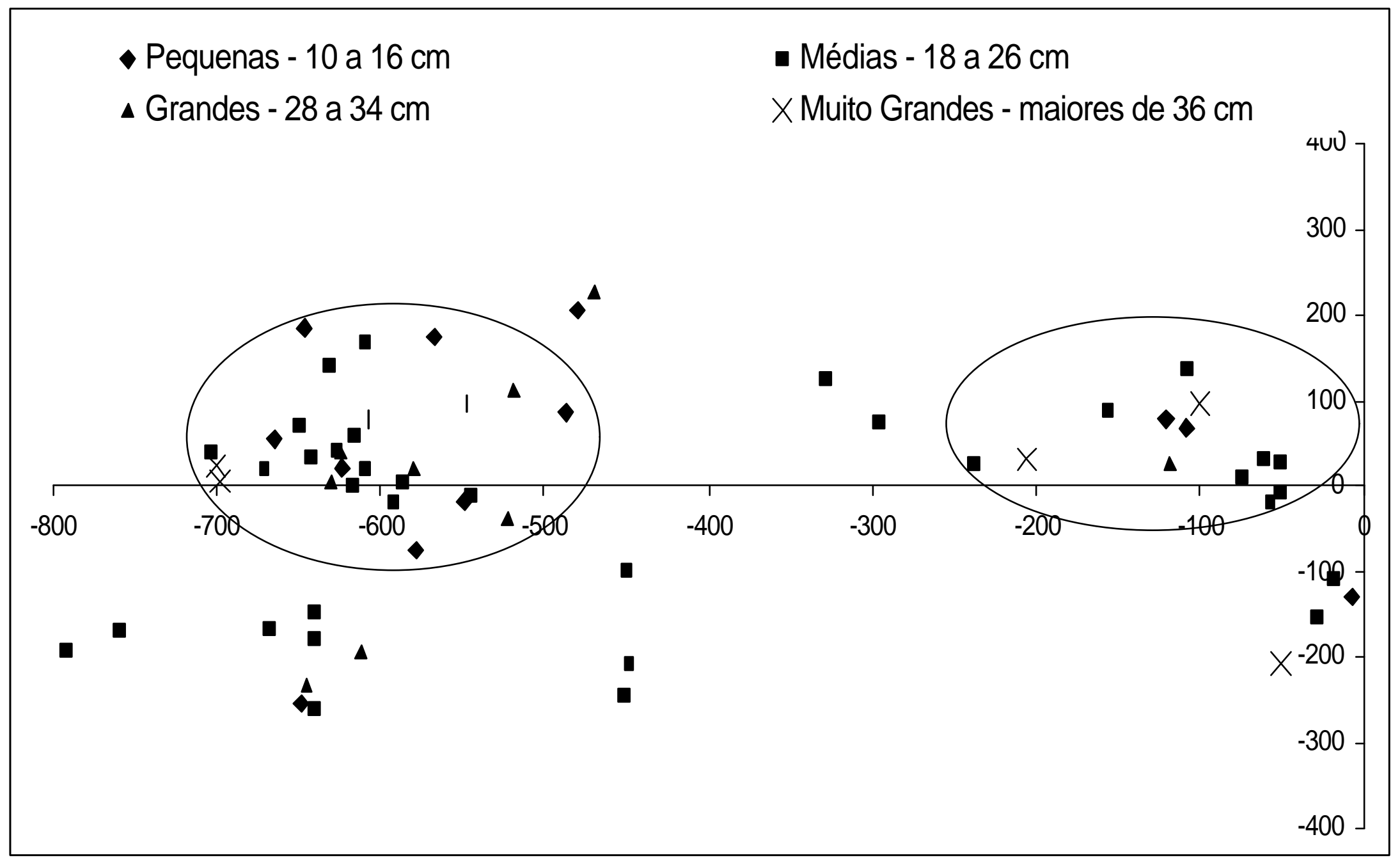

Gráfico 40 : Dispersão dos fragmentos de borda de tigelas de beber nos setores III a VI. Considerando que as dimensões refiram-se a consumo individual e/ou coletivo, dois agrupamentos podem ser visualizados. 


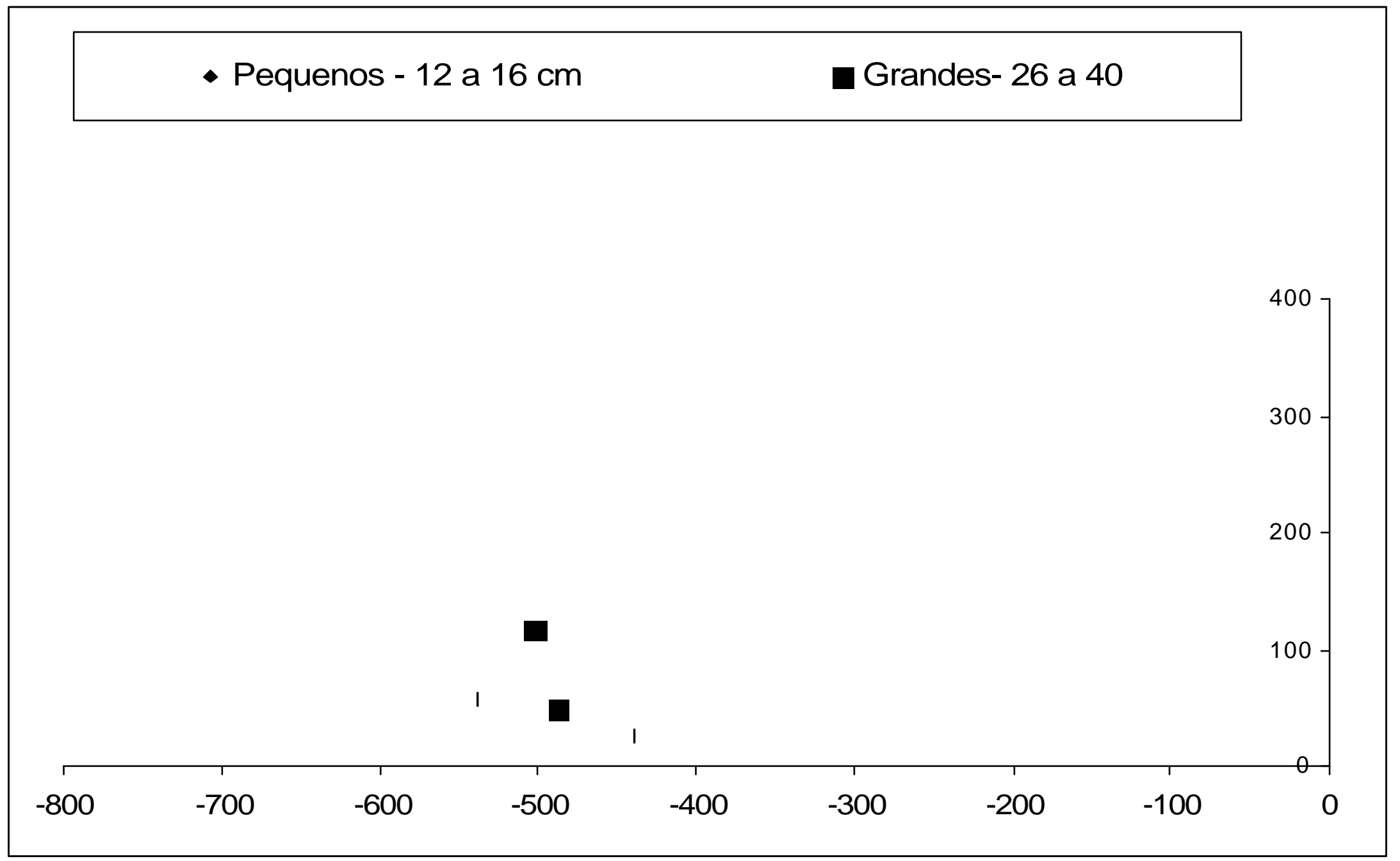

Gráfico 41: Dispersão dos fragmentos de borda de pratos no setor 1. Não há pratos médios. 


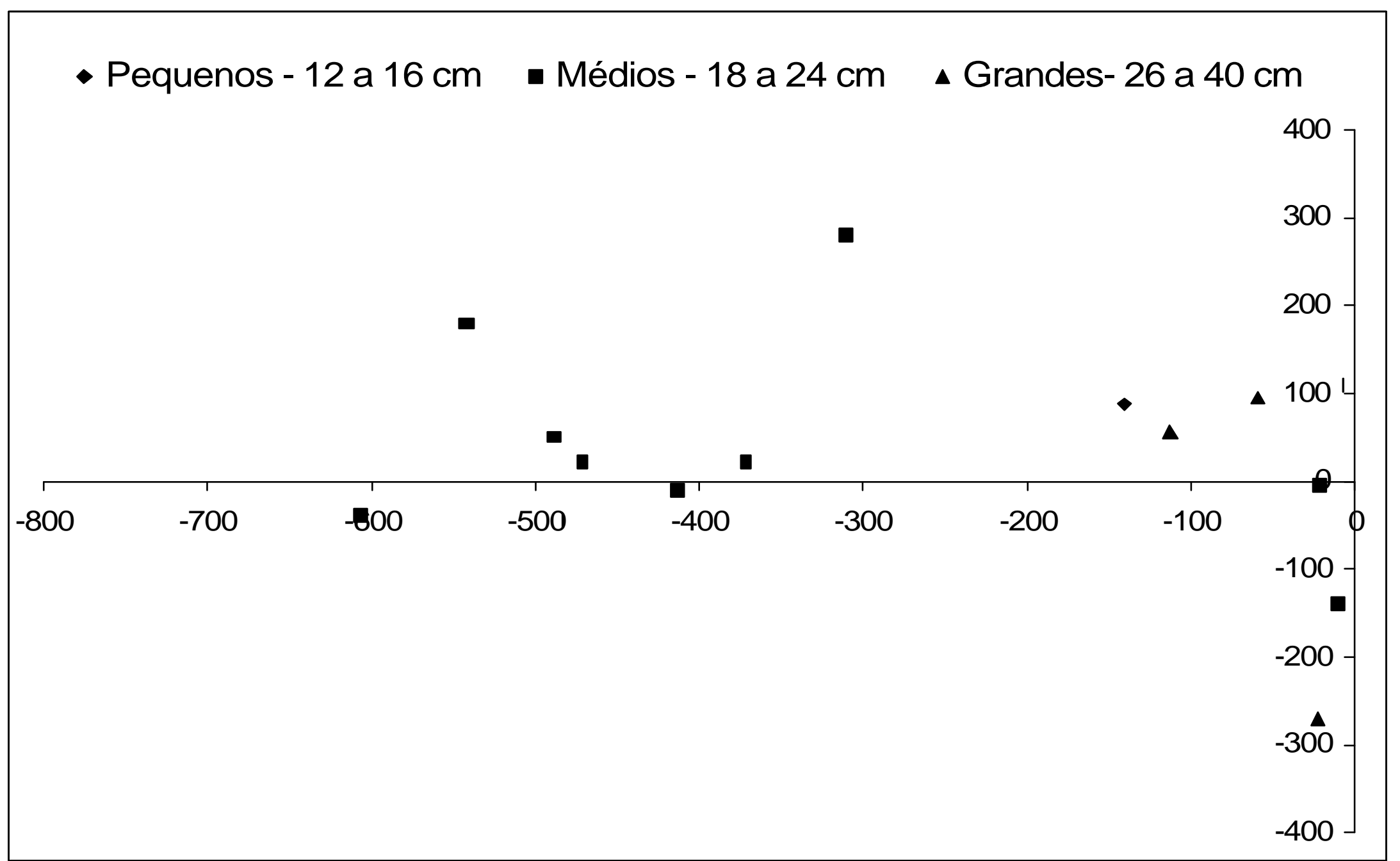

Gráfico 42 : Dispersão dos fragmentos de borda de pratos nos setores III a VI. 
Soares,A.L.R. 2004 - Contribuição à Arqueologia Guarani: estudo do sítio Röpke

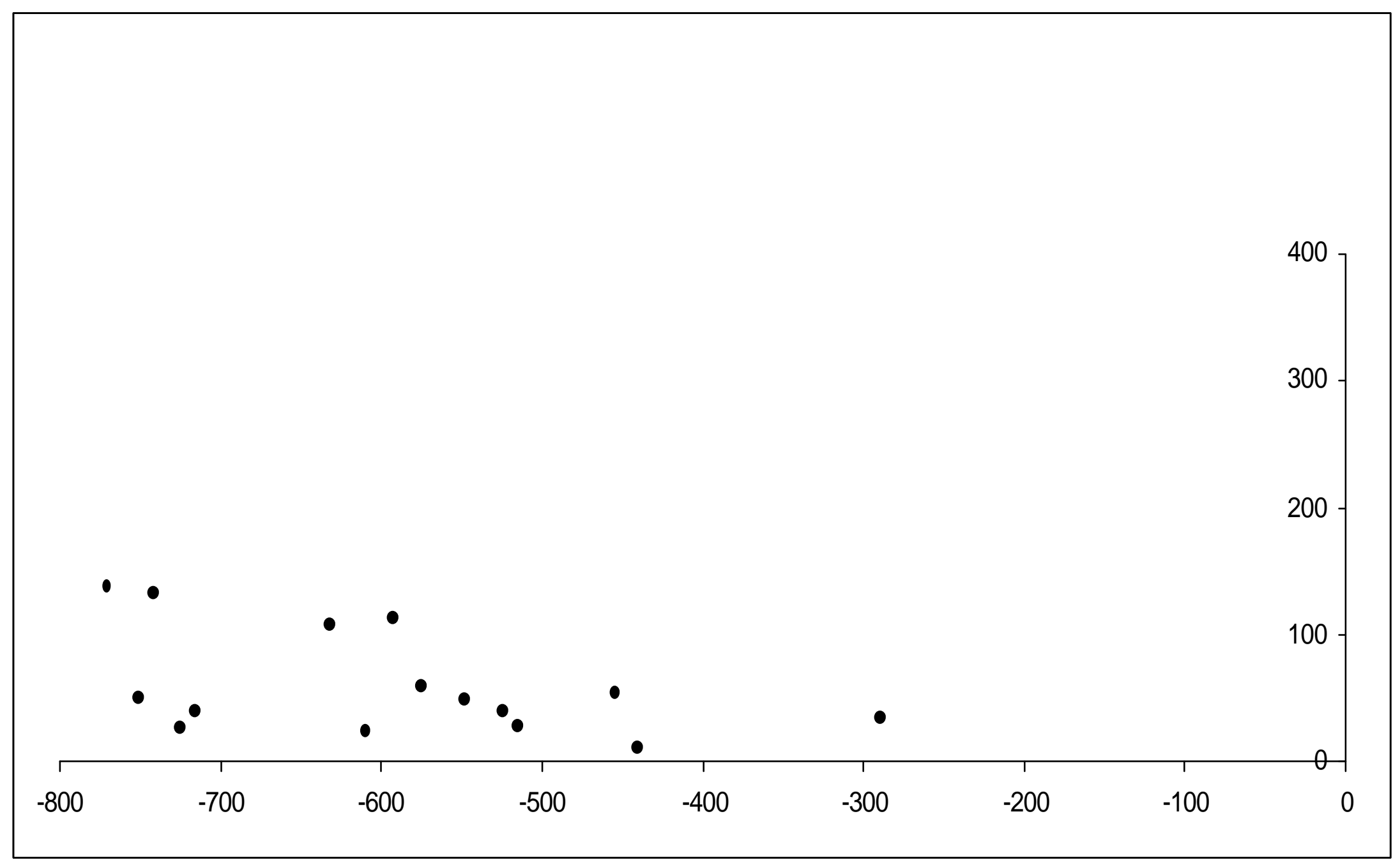

Gráfico 43 : Dispersão dos fragmentos de carvão no setor 1. 
Soares,A.L.R. 2004 - Contribuição à Arqueologia Guarani: estudo do sítio Röpke

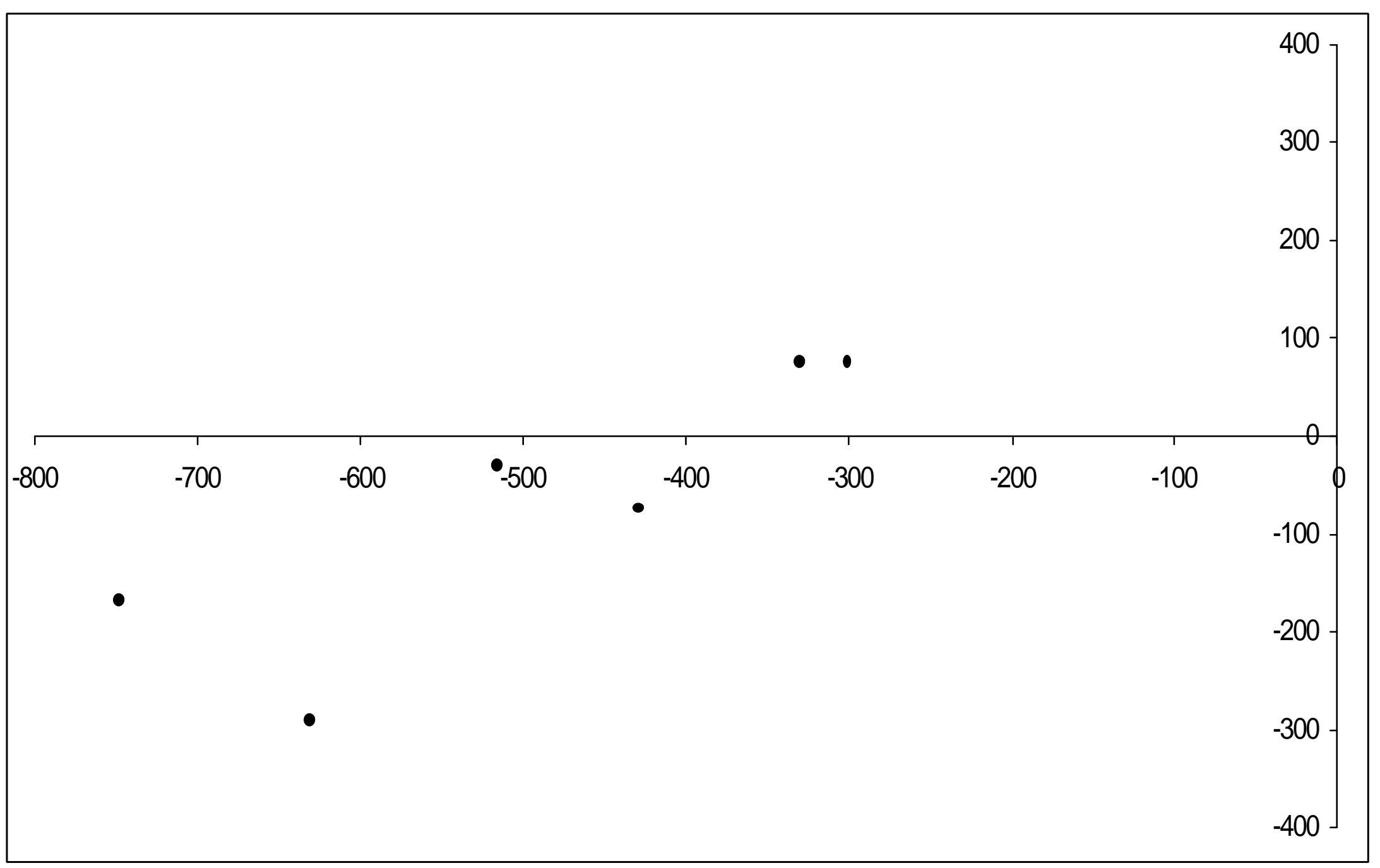

Gráfico 44 : Dispersão dos fragmentos de carvão nos setores III a VI. 
Soares,A.L.R. 2004 - Contribuição à Arqueologia Guarani: estudo do sítio Röpke

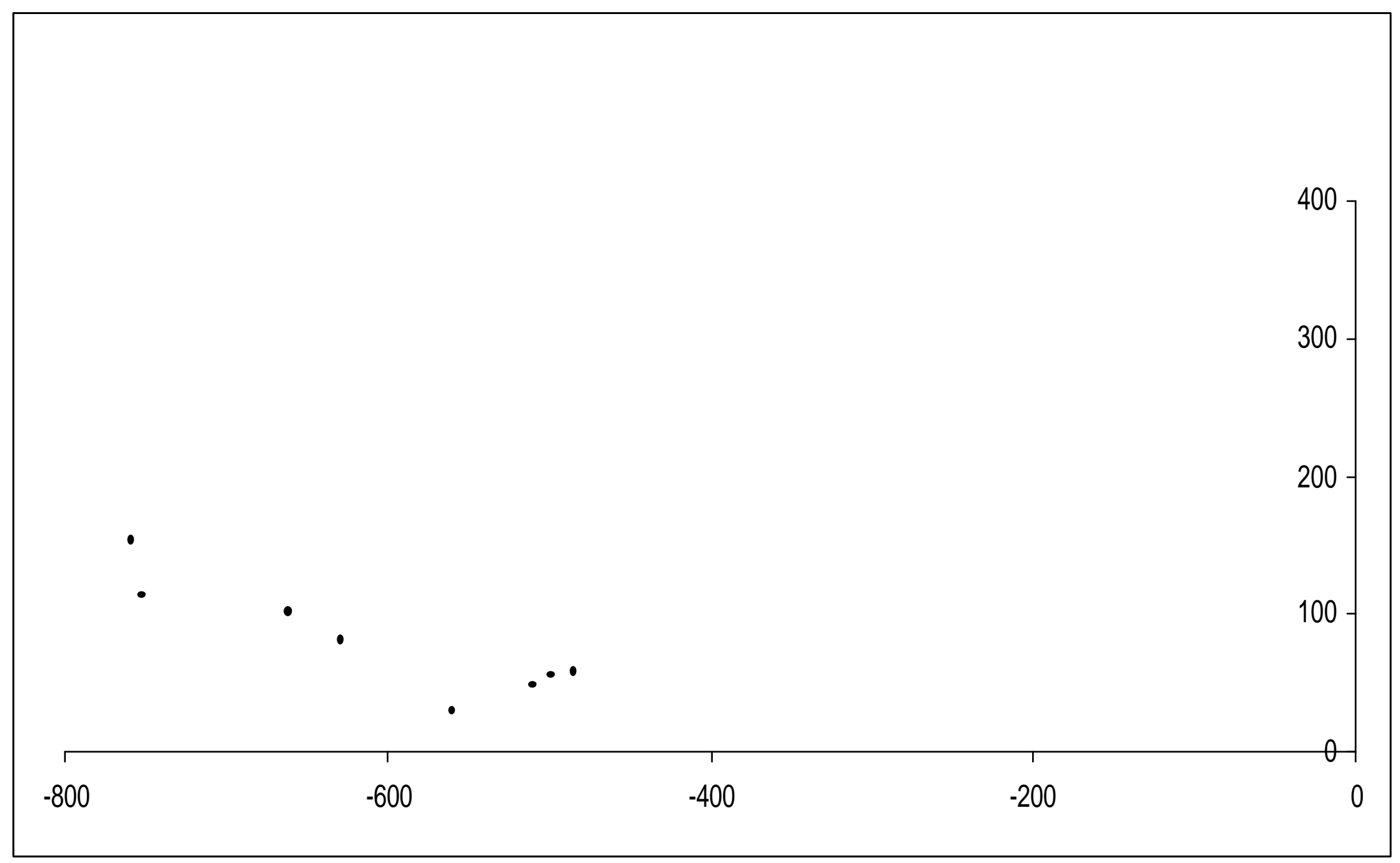

Gráfico 45 : Dispersão dos fragmentos de hematita no setor 1. 
Soares,A.L.R. 2004 - Contribuição à Arqueologia Guarani: estudo do sítio Röpke

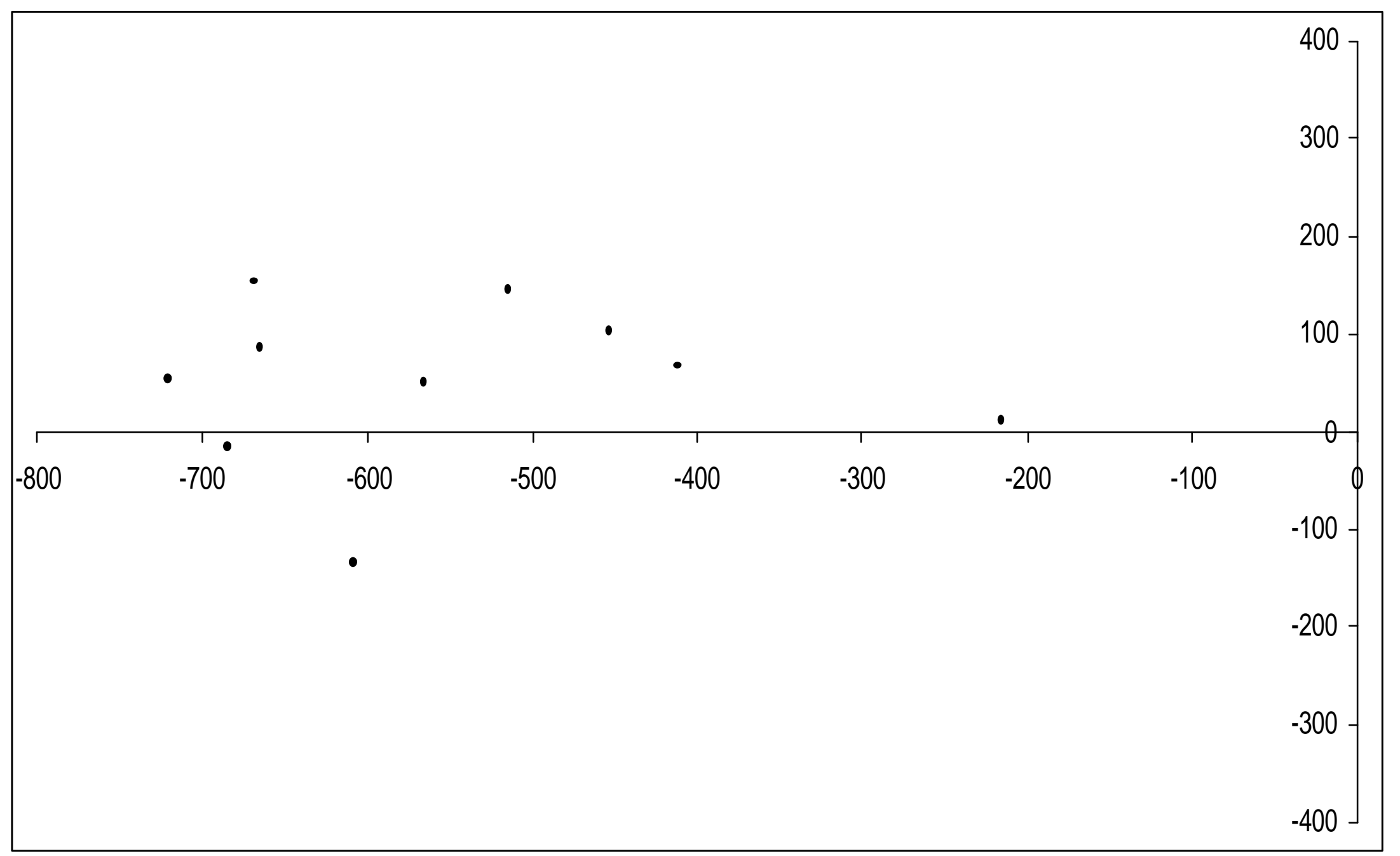

Gráfico 46 : Dispersão dos fragmentos de hematita nos setores III a VI. 


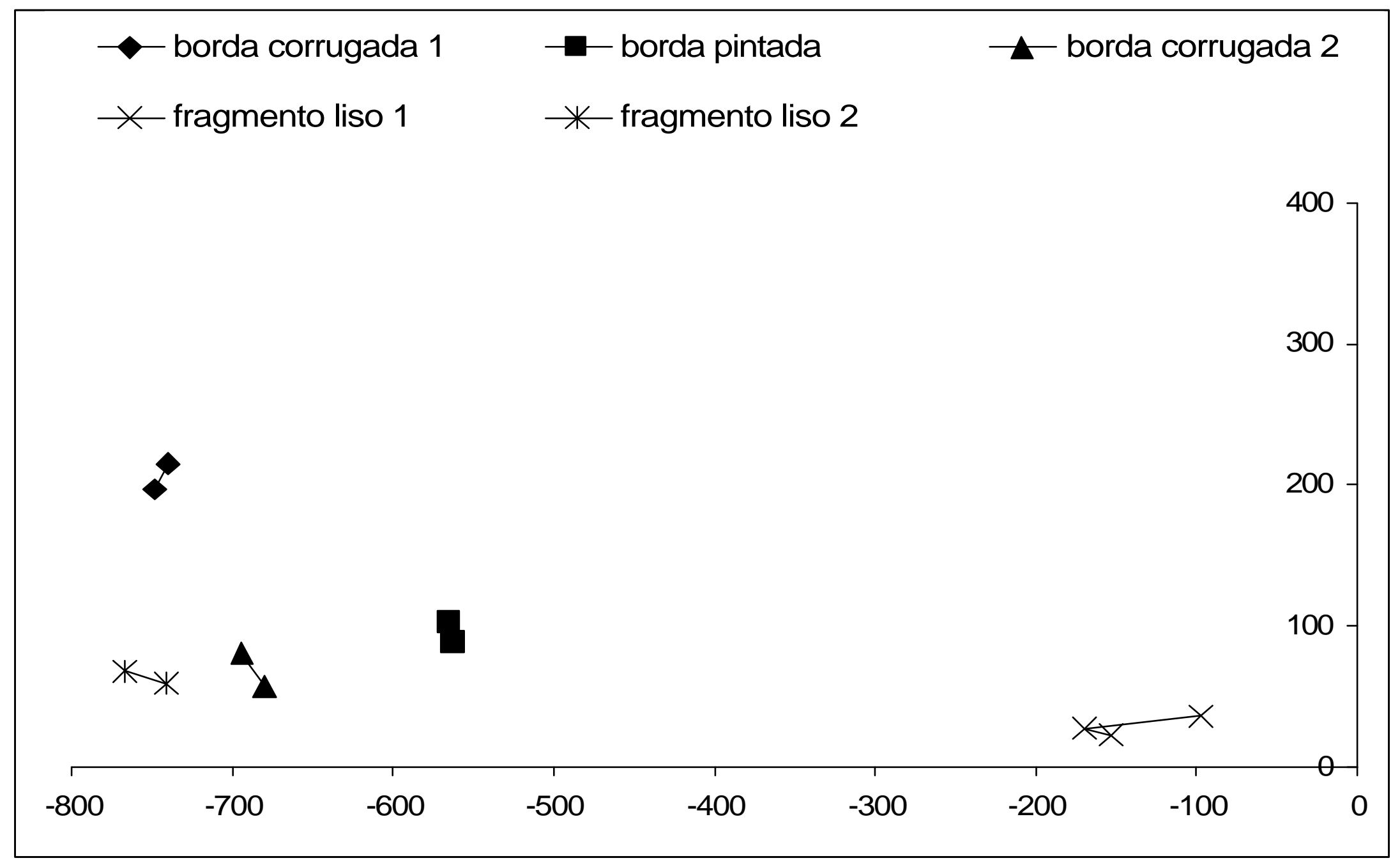

Gráfico 47: Dispersão da cerâmica que encontrava-se fragmentada e cujas peças foram coladas no setor 1. 


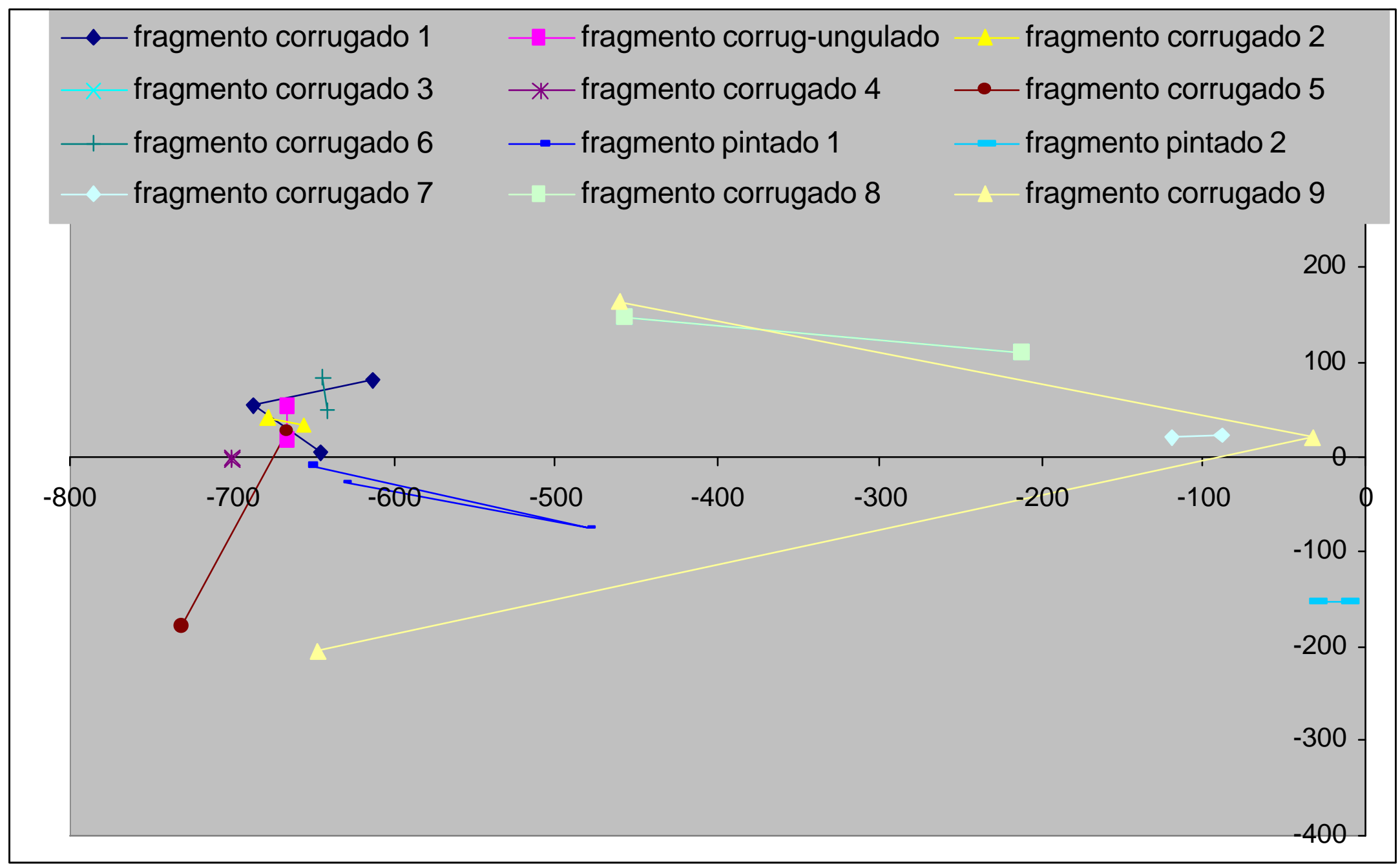

Gráfico 48: Dispersão da cerâmica que encontrava-se fragmentada e cujas peças foram coladas nos setores III a VI. 


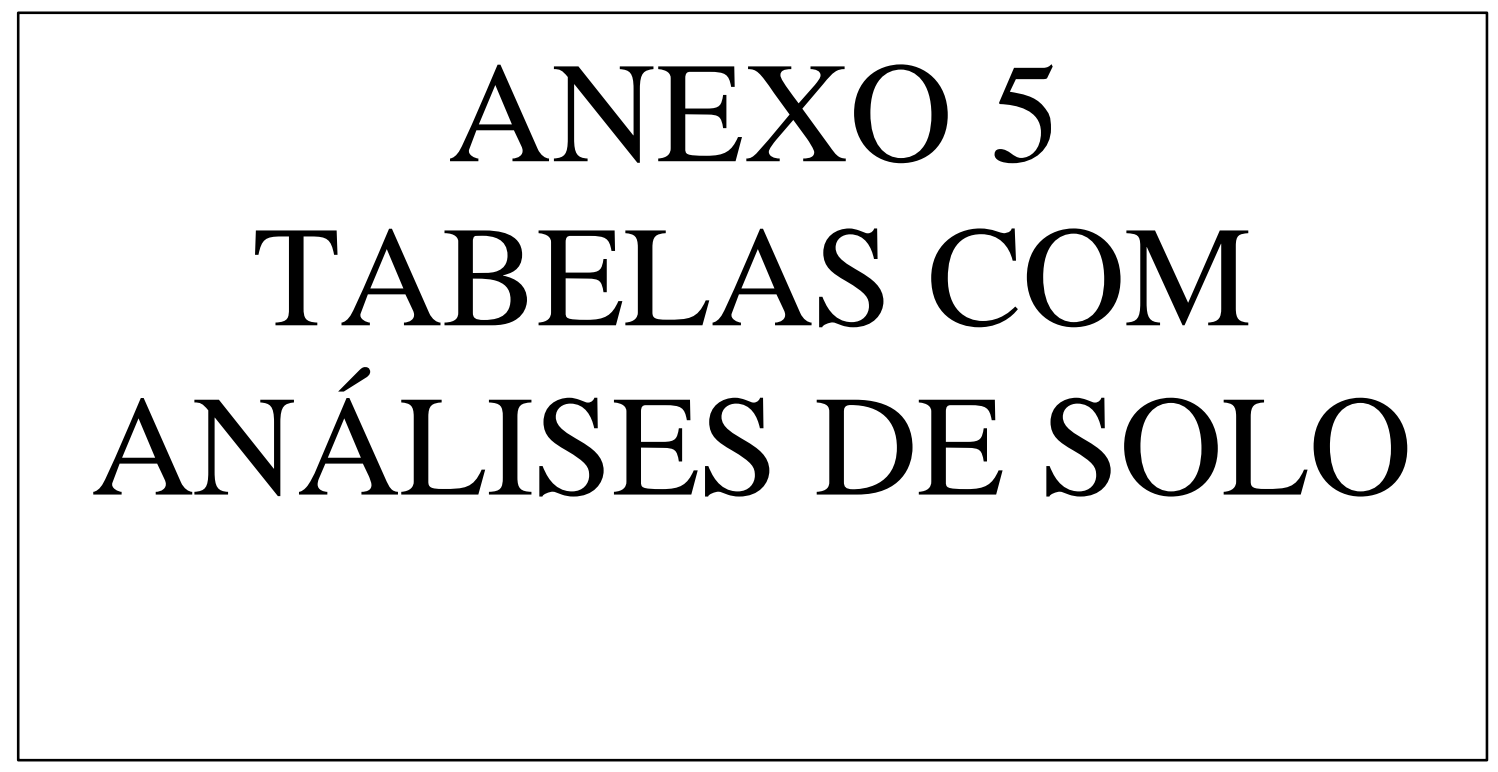


Tabela 1 - Análise de solo por digestão total, realizada pelo Embrapa Solos - Rio de Janeiro: atributos da fertilidade do solo segundo Embrapa (1997). Análise realizada pelo Dr. Vinícius Benites e a Ph.D. Beata Madari.

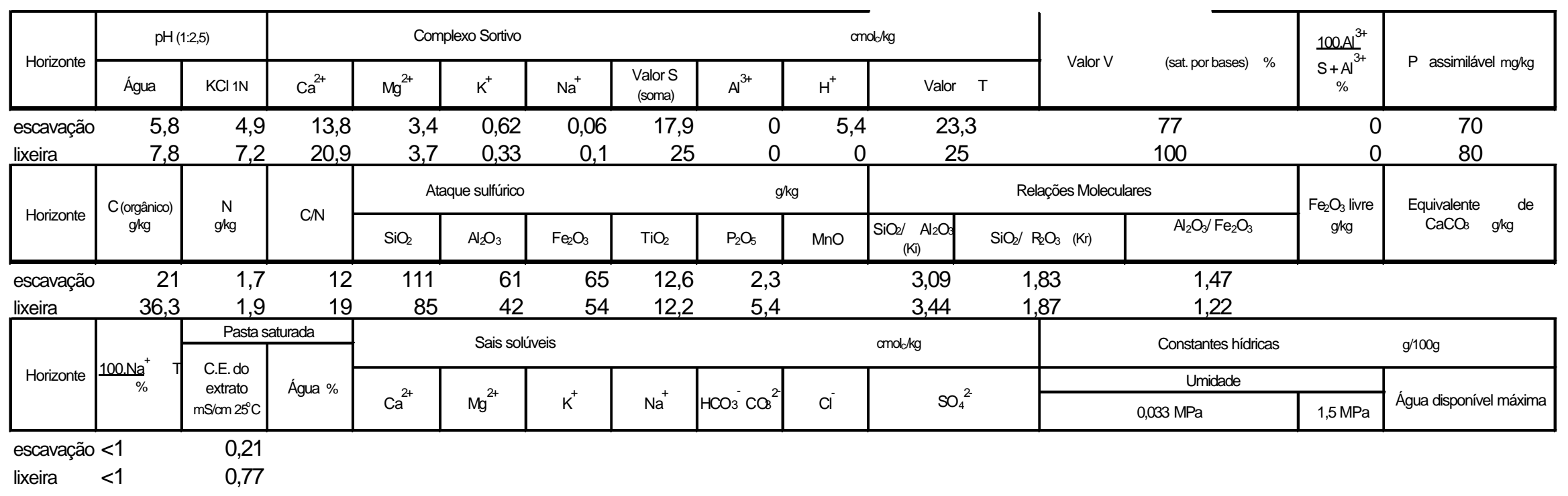


Tabela 2: Comparação das análises realizadas pelo Embrapa-Solos -RJ, Museu Paraense Emílio Goeldi (MPEG) e os dados referentes a outros sítios de Terra Preta publicados.

Legenda:

Ropke Amostra 1 (Embrapa): Lixeira sem peneiramento (significa que o solo enviado para análise não foi peneirado, permanecendo os elementos macroscópicos orgânicos). Análise realizada por Digestão total pelos pesquisadores Dr. Vinicius Benites e Dra. Ph.D. Beata Madari.

Ropke amostra 2 (Embrapa): Lixeira com peneiramento (significa que o solo enviado para análise foi peneirado, sendo retirados os elementos macroscópicos orgânicos)

Ropke amostra 3 (Embrapa): Área de escavação sem peneiramento (amostra de solo da área de escavação, sendo enviado uma parcela do núcleo de solo antropogênico sem a retirada dos vestígios de fauna e flora existentes)

Ropke amostra 4 (Embrapa): Solo adjacente (amostra de solo da área de escavação que não apresentava núcleo antropogênico, sem evidências de ocupação ou alteração antrópica)

Ropke amostra 5 (MPEG): amostra semelhante a amostra 1. Análise realizada pelo pesquisador Dr. Hilton Túlio Costi, no Museu Paraense Emílio Goeldi.

Ropke amostra 6 (MPEG): amostra semelhante a amostra 3 (escavação). Análise realizada pelo pesquisador Dr. Hilton Túlio Costi, no Museu Paraense

Emílio Goeldi.

Ropke amostra 7 (MPEG): amostra semelhante a amostra 4 (solo adjacente). Análise realizada pelo pesquisador Dr. Hilton Túlio Costi, no Museu Paraense Emílio Goeldi.

\begin{tabular}{|c|c|c|c|c|c|c|c|c|c|c|c|}
\hline Análise & $\begin{array}{c}\text { Ropke- } \\
\text { Amostra } 1 \\
\text { (Embrapa) }\end{array}$ & $\begin{array}{c}\text { Ropke: } \\
\text { amostra } 2 \\
\text { (Embrapa) }\end{array}$ & $\begin{array}{c}\text { Ropke - } \\
\text { Amostra } 3 \\
\text { (Embrapa) }\end{array}$ & $\begin{array}{c}\text { Ropke: } \\
\text { amostra } 4 \\
\text { (Embrapa) }\end{array}$ & $\begin{array}{c}\text { Ropke } \\
\text { amostra } 5 \\
\text { (MPEG) }\end{array}$ & $\begin{array}{c}\text { Ropke } \\
\text { amostra } 6 \\
\text { (MPEG) }\end{array}$ & $\begin{array}{c}\text { Ropke } \\
\text { amostra } 7 \\
\text { (MPEG) }\end{array}$ & $\begin{array}{c}\mathrm{TP}- \\
\text { Belterra } \\
\text { (Pabst, } \\
1991)\end{array}$ & $\begin{array}{c}\text { Latossol- } \\
\text { Belterra } \\
\text { (Pabst, } \\
1991)\end{array}$ & $\begin{array}{c}\text { Sítio Alves } \\
\text { (Pallestrini, 1969) } \\
\text { Terra Vermelha }\end{array}$ & $\begin{array}{c}\text { Sítio Alves } \\
\text { (Pallestrini, } \\
\text { 1969) Terra } \\
\text { Preta } \\
\end{array}$ \\
\hline $\mathrm{Ph}(\mathrm{KCl})$ & 7,2 & $X$ & 4,9 & $X$ & $\mathrm{X}$ & $X$ & $X$ & $\mathrm{X}$ & X & 4,3 & 5 \\
\hline $\mathrm{Ph} \mathrm{H} 2 \mathrm{O}$ & 7,8 & $X$ & 5,8 & $X$ & 7,8 & 5,8 & 4,8 & 6,4 & 3,77 & 5,2 & 5,5 \\
\hline $\mathrm{MO}$ & 4,8 & $\mathrm{X}$ & 3,9 & $\mathrm{X}$ & $\mathrm{X}$ & $\mathrm{X}$ & $X$ & 1,57 & 0,7 & $\mathrm{X}$ & $\mathrm{X}$ \\
\hline $\mathrm{Ca}$ & 14.1 & 13.6 & 3.60 & 1.73 & 18 & 12,2 & 0,1 & 5,2 & 0,8 & 0,45 & 0,4 \\
\hline $\mathrm{Mg}$ & 14.1 & 13.6 & 3.60 & 1.73 & 0,8 & 1,07 & 0,1 & 6,7 & 0,5 & imp. & 0,15 \\
\hline $\mathrm{K}$ & 14.1 & 13.6 & 3.60 & 1.73 & 0,4 & 0,7 & 0,2 & 0,12 & 0,16 & 0,02 & 0,02 \\
\hline $\mathrm{Na}$ & 14.1 & 13.6 & 3.60 & 1.73 & 0.7 & 0,8 & 0,2 & $\mathrm{X}$ & $\mathrm{X}$ & $\mathrm{X}$ & $\mathrm{X}$ \\
\hline $\mathrm{Zn}$ & 0.104 & $X$ & 0.118 & $X$ & $X$ & $X$ & $X$ & $\mathrm{X}$ & $X$ & $X$ & $\mathrm{X}$ \\
\hline $\mathrm{P}$ & $80 / 69,5^{*}$ & $\mathrm{X}$ & $70 / 23,5^{*}$ & $\mathrm{X}$ & $\mathrm{X}$ & $\mathrm{X}$ & $\mathrm{X}$ & 14,28 & 2,19 & $X$ & $\mathrm{X}$ \\
\hline $\mathrm{N}$ & 1,9 & $X$ & 1,7 & $\mathrm{X}$ & $X$ & $X$ & $X$ & 0,348 & 0,139 & 0,02 & 0,07 \\
\hline $\begin{array}{r}\mathrm{T} \text { (troca } \\
\text { catiônica) }\end{array}$ & 25 & $X$ & 23,5 & $\mathrm{X}$ & $\mathrm{X}$ & $\mathrm{X}$ & $\mathrm{X}$ & 40 & 15 & 2,32 & 5,82 \\
\hline
\end{tabular}


Tabela 3: Outros elementos analisados pelo EMBRAPA-Solos (RJ)

\begin{tabular}{|c|c|c|c|c|}
\hline & Amostra 1 & Amostra 2 & Amostra 3 & Amostra 4 \\
\hline $\mathrm{Al}$ & 21.6 & 20.9 & 26.4 & 23.4 \\
\hline $\mathrm{Fe}$ & 31.4 & 29.8 & 33.3 & 33.4 \\
\hline $\mathrm{Mn}$ & 0.833 & 0.814 & 1.25 & 0.991 \\
\hline $\mathrm{Zn}$ & 0.104 & 0.119 & 0.118 & 0.079 \\
\hline $\mathrm{Cu}$ & 0.041 & 0.042 & 0.041 & 0.037 \\
\hline $\mathrm{Cr}$ & 0.004 & 0.005 & 0.021 & 0.007 \\
\hline $\mathrm{Co}$ & 0.018 & 0.018 & 0.020 & 0.023 \\
\hline $\mathrm{Ni}$ & 0.017 & 0.017 & 0.001 & 0.016 \\
\hline $\mathrm{Cd}$ & 0.001 & 0.001 & 0.013 & 0.001 \\
\hline $\mathrm{Pb}$ & 0.012 & 0.010 & & 0.014 \\
\hline
\end{tabular}


Tabela 4: Análise de sedimentos realizada pelo Laboratório Central de Análise de Solo. Agradece-se ao pesquisador Luiz Finamor pela interpretação dos dados.

\section{MEC - Universidade Federal de Santa Maria Centro de Ciências Rurais - Departamento de Solos \\ Laboratório Central de Análises de Solo
Fones: (055) 220-8153 e 220-8108 Fax: 220 - 8695 \\ Internet: http://www. ufsm.br/ccr/solos/ \\ Vinculado à Rede Oficial de Laboratórios de Análise de Solos do RS e SC - ROLAS}

\section{Laudo de Análisè de Solo}

$\begin{array}{llll}\text { Nome: } & \text { LABORATÓRIO ARQUUIOLOGIA } & \text { Municipio: } & \text { AGUDO } \\ \text { Endereço: } & - & \text { Localidade: } & \text { B. DONA FRANCISCA } \\ \text { Fone: } & - & \text { Data entrada: } & 06 / 02 / 2002 \\ \text { Fax: } & \text { PROF ANDRÉ SOARES } & \text { Data Emissăo: } & 06 / 02 / 2002 \\ \text { Solicitante: } & \text { PROF }^{\circ} \text { AN } & \text { Necibo: } & 000000002\end{array}$

\begin{tabular}{|l|l|}
\hline $\mathrm{N}^{\circ}$ & Registro \\
\hline 1 & 7947 \\
2 & 7948 \\
3 & 7949 \\
4 & 7950 \\
5 & 7951 \\
\hline
\end{tabular}

\begin{tabular}{|c|c|c|c|c|c|c|}
\hline Textura & $\begin{array}{c}\text { \% argila } \\
\mathrm{m} / \mathrm{V}\end{array}$ & $\begin{array}{c}\mathrm{pH} \cdot \mathrm{H}_{2} \mathrm{O} \\
\text { 1:1 }\end{array}$ & $\begin{array}{c}\text { Indice } \\
\text { SMP }\end{array}$ & $\begin{array}{c}\mathrm{P} \\
\mathrm{mg} / \mathrm{L}\end{array}$ & $\begin{array}{c}\mathrm{K} \\
\mathrm{mg} / \mathrm{L}\end{array}$ & $\begin{array}{c}\% \mathrm{M} . \mathrm{O} . \\
\mathrm{m} / \mathrm{V}\end{array}$ \\
\hline & 18 & 6.2 & 6.1 & 69.5 & 194.0 & 4.8 \\
4 & 18 & 7.2 & 7.1 & 69.5 & 92.0 & 0.0 \\
4 & 22 & 5.4 & 5.6 & 23.2 & 200.0 & 3.9 \\
3 & 26 & 6.2 & 6.0 & 15.0 & 200.0 & 0.7 \\
3 & 26 & 6.9 & 6.5 & 42.8 & 200.0 & 1.0 \\
4 & 24 & 6.9 &
\end{tabular}

\begin{tabular}{|c|c|c|}
\hline $\begin{array}{c}\mathrm{Al} \\
\mathrm{cmol} / \mathrm{L}\end{array}$ & $\begin{array}{c}\mathrm{Ca} \\
\mathrm{cmol} / \mathrm{L}\end{array}$ & $\begin{array}{c}\mathrm{Mg} \\
\mathrm{cmol} / \mathrm{L}\end{array}$ \\
\hline 0.0 & 18.2 & 1.8 \\
0.0 & 22.0 & 1.6 \\
0.0 & 13.5 & 1.9 \\
0.0 & 15.3 & 3.2 \\
0.0 & 16.3 & 2.1 \\
\hline
\end{tabular}

\begin{tabular}{|c|c|c|c|c|c|c|}
\hline \multirow[t]{2}{*}{$\mathrm{N}^{\circ}$} & \multirow[t]{2}{*}{ Registro } & \multirow{2}{*}{$\begin{array}{l}\mathrm{H}+\mathrm{AL} \\
\mathrm{cmol} / \mathrm{L}\end{array}$} & \multicolumn{2}{|c|}{ CTC $\mathrm{cmol}_{\mathrm{c}} / \mathrm{L}$} & \multicolumn{2}{|c|}{ Saturação \% } \\
\hline & & & efetiva & $\mathrm{pH} 7$ & Al & Bases \\
\hline 1 & 7947 & 3.3 & 20.5 & 23.8 & 0 & 86 \\
\hline 2 & 7948 & 1.3 & 23.8 & 25.2 & 0 & 95 \\
\hline 3 & 7949 & 5.1 & 15.9 & 21.0 & 0 & 76 \\
\hline 4 & 7950 & 3.6 & 19.0 & 22.6 & 0 & 84 \\
\hline 5 & 7951 & 2.3 & 18.9 & 21.2 & 0 & 89 \\
\hline
\end{tabular}

\begin{tabular}{|c|c|c|c|}
\hline $\begin{array}{c}\mathrm{S} \\
\mathrm{mg} / \mathrm{L}\end{array}$ & $\begin{array}{c}\mathrm{Cu} \\
\mathrm{mg} / \mathrm{L}\end{array}$ & $\begin{array}{c}\mathrm{Zn} \\
\mathrm{mg} / \mathrm{L}\end{array}$ & $\begin{array}{c}\mathrm{B} \\
\mathrm{mg} / \mathrm{L}\end{array}$ \\
\hline $\mathrm{-x}-$ & 1.4 & 25.1 & $-\mathrm{x}-$ \\
$-\mathrm{x}-$ & 0.1 & 3.3 & $-\mathrm{x}-$ \\
$-\mathrm{x}-$ & 2.2 & 23.9 & $-\mathrm{x}-$ \\
$-\mathrm{x}-$ & 0.8 & 10.6 & $-\mathrm{x}-$ \\
$-\mathrm{x}-$ & 0.7 & 8.7 & $-\mathrm{x}-$ \\
\hline
\end{tabular}

Obs: $\mathrm{mg} / \mathrm{L}=\mathrm{ppm}, \mathrm{cmol} / \mathrm{L}=\mathrm{meq} / 100 \mathrm{~g}$

CTC efetiva - quantidade de carga ao $\mathrm{pH}$ natural do solo

$\mathrm{CTC} \mathrm{pH} 7,0$ - quantidade de carga estimada a $\mathrm{pH} 7,0$

\begin{tabular}{|c|l|c|c|c|c|}
\hline $\mathrm{N}^{\circ}$ & \multicolumn{1}{|c|}{ Identificação da Amostra } & $\begin{array}{c}\mathrm{Fe} \\
\mathrm{mg} / \mathrm{L}\end{array}$ & $\begin{array}{c}\mathrm{Mn} \\
\mathrm{mg} / \mathrm{L}\end{array}$ & $\begin{array}{c}\mathrm{Na} \\
\mathrm{mg} / \mathrm{L}\end{array}$ & $\begin{array}{c}\mathrm{Mo} \\
\mathrm{mg} / \mathrm{L}\end{array}$ \\
\hline 1 & 01 -LIX. S/ OSSOS & 9.4 & 14 & $-\mathrm{x}-$ & $-\mathrm{x}-$ \\
2 & 02 - LIX. C/ OSSOS & 3.3 & 0.1 & $-\mathrm{x}-$ & $-\mathrm{x}-$ \\
3 & 03 - SETOR 1-X X.5 & 29.3 & 0.1 & $-\mathrm{x}-$ & $-\mathrm{x}-$ \\
4 & 04 - CERÃMICA PINTADA & 69 & 8.4 & $-\mathrm{x}-$ & $-\mathrm{x}-$ \\
5 & 05 - LIX. CER. PINTADA & 94.7 & 0.2 & $-\mathrm{x}-$ & $-\mathrm{x}-$ \\
\hline
\end{tabular}

\begin{tabular}{|r|r|r|r|}
\hline \multicolumn{4}{|c|}{ Relações } \\
\hline $\mathrm{Ca} / \mathrm{Mg}$ & $\mathrm{Ca} / \mathrm{K}$ & \multicolumn{1}{|c|}{$\mathrm{Mg} / \mathrm{K}$} & $\mathrm{K} / \sqrt{\mathrm{Ca}^{\mathrm{M} / \mathrm{s}}}$ \\
\hline 10.1 & 36.6 & 3.6 & 0.111 \\
13.8 & 93.3 & 6.8 & 0.049 \\
7.1 & 26.3 & 3.7 & 0.131 \\
4.8 & 29.8 & 6.2 & 0.119 \\
7.8 & 31.8 & 4.1 & 0.120 \\
\hline
\end{tabular}

Respgnsévetstégrico 


\section{ANEXO 6 TABELA COM QUANTIFICAÇÃO CERÂMICA}


Tabela 1: Funcionalidade das vasilhas e quantificacão segundo os diâmetros de boca das vasilhas

\begin{tabular}{|c|c|c|c|c|c|c|c|c|c|}
\hline \multicolumn{2}{|c|}{ Panelas } & \multicolumn{2}{|c|}{ Tigelas } & \multicolumn{2}{|c|}{ Tigelas de beber } & \multicolumn{2}{|l|}{ Pratos } & \multicolumn{2}{|l|}{ Talhas } \\
\hline $\begin{array}{c}\text { Diâmetro } \\
\text { de boca }\end{array}$ & $\begin{array}{l}\text { Número de } \\
\text { fragmentos }\end{array}$ & $\begin{array}{c}\text { Diâmetro } \\
\text { de boca }\end{array}$ & $\begin{array}{l}\text { Número de } \\
\text { fragmentos }\end{array}$ & $\begin{array}{c}\text { Diâmetro } \\
\text { de boca }\end{array}$ & $\begin{array}{l}\text { Número de } \\
\text { fragmentos }\end{array}$ & $\begin{array}{c}\text { Diâmetro } \\
\text { de boca }\end{array}$ & $\begin{array}{l}\text { Número de } \\
\text { fragmentos }\end{array}$ & $\begin{array}{c}\text { Diâmetro } \\
\text { de boca }\end{array}$ & $\begin{array}{l}\text { Número de } \\
\text { fragmentos }\end{array}$ \\
\hline 10 & 3 & 8 & 2 & 10 & 2 & 12 & 3 & 38 & 2 \\
\hline 12 & 5 & 10 & 1 & 12 & 4 & 14 & 2 & * & 1 \\
\hline 14 & 14 & 12 & 1 & 14 & 9 & 16 & 2 & 48 & 1 \\
\hline 15 & 1 & 14 & 4 & 16 & 4 & 18 & 2 & 24 & 1 \\
\hline 16 & 14 & 16 & 1 & 18 & 10 & 20 & 3 & & \\
\hline 17 & 2 & 18 & 4 & 20 & 12 & 22 & 3 & & \\
\hline 18 & 17 & 20 & 8 & 22 & 3 & 24 & 3 & & \\
\hline 20 & 20 & 22 & 6 & 24 & 5 & 26 & 1 & & \\
\hline 22 & 5 & 24 & 5 & 26 & 6 & 32 & 2 & & \\
\hline 24 & 12 & 26 & 5 & 28 & 2 & 40 & 1 & & \\
\hline 26 & 10 & 28 & 1 & 30 & 5 & & & & \\
\hline 28 & 5 & 30 & 4 & 33 & 1 & & & & \\
\hline 30 & 3 & 32 & 4 & 34 & 3 & & & & \\
\hline 32 & 2 & 34 & 2 & 36 & 1 & & & & \\
\hline 34 & 4 & 36 & 2 & 38 & 2 & & & & \\
\hline 36 & 4 & 38 & 2 & 46 & 2 & & & & \\
\hline 38 & 1 & 40 & 2 & & & & & & \\
\hline 39 & 1 & 44 & 2 & & & & & & \\
\hline 40 & 2 & 48 & 1 & & & & & & \\
\hline 42 & 4 & 66 & 1 & & & & & & \\
\hline 44 & 1 & & & & & & & & \\
\hline 46 & 2 & & & & & & & & \\
\hline 50 & 2 & & & & & & & & \\
\hline 52 & 1 & & & & & & & & \\
\hline 60 & 2 & & & & & & & & \\
\hline
\end{tabular}




\section{ANEXO 7 DATAÇÕES}




\section{Faculdade de Tecnologia de São Paulo \\ Centro Estadual de Educação Tecnológica Paula Souza \\ VINCULADO E ASSOCIADO A UNESP}

\section{Datacãa pelo Método de Termoluminescência}

\section{São Paulo, 21 de Agosto de 2003.}

\section{Ilmo Sr. Prof. Dr. André Soares}

Estou enviando os dados das medidas realizadas pelo nosso laboratório, referentes à datação por Termoluminescência das amostras de cerâmicas conforme informações abaixo:

- Pesquisador responsável : Prof. Dr. André Soares

- Responsáveis pela Datação : Giuliano Gozzi - LVD / FATEC-SP.

\section{$\underline{\text { Resultados }}$}

\begin{tabular}{|c|c|c|c|c|}
$\begin{array}{c}\text { Código } \\
\text { do LVD }\end{array}$ & Amostra & $P(G y)$ & DA $\left(10^{-6}\right.$ Gy/ano $)$ & $\begin{array}{c}\text { Idade BP } \\
\text { (anos) }\end{array}$ \\
\hline 939 & $\mathbf{N}^{0} 2250$ Setor III & - & - & - \\
\hline $940 \mathrm{a}$ & $\mathbf{N}^{0} 1828$ Lixeira ou Geral & 1,71 & $1248 \pm 28$ & $1370 \pm 160$ \\
\hline $940 \mathrm{~b}$ & $\mathbf{N}^{0} 1828$ Lixeira ou Geral & 1,76 & $1430 \pm 36$ & $1200 \pm 65$ \\
\hline $941 \mathrm{a}$ & $\mathbf{N}^{0} 257$ Setor I & 1,46 & $1315 \pm 33$ & $1100 \pm 78$ \\
\hline $941 \mathrm{~b}$ & $\mathbf{N}^{0} 257$ Setor I & 1,20 & $1174 \pm 27$ & $1000 \pm 240$ \\
\hline
\end{tabular}

\section{Prof. ${ }^{a}$ Dr. a Sonia Hatsue Tatumi}

Coordenadora do Laboratório 


\section{Laboratório de Vidros e Datação Faculdade de Tecnologia de São Paulo Centro Estadual de Educação Tecnológica Paula Souza VINCULADO E ASSOCIADO A UNESP}

\section{Relatório de Ensaio}

\section{CLIENTE: ANDRE SOARES}

MATERIAL: Cerâmicas arqueológicas

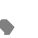

NATUREZA DO TRABALHO: D atação de Cerâmicas pelo método da Termoluminescência.

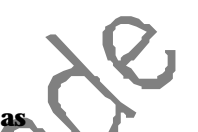

REFERÊNCIA: Cartą de 02/2004

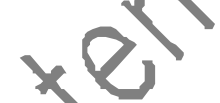
AMÓSTRAS

Foram fornecidas pelo cliente quatro amostras co $m$ as designações indicadas na Tabela 1 , acondicionadas em sacos plásticos contendo cerca de $100 \mathrm{~g}$ de cada uma. As amostras foram recebidas em 02/ 2004 e identificadas no laboratório como 1040 a 1043, respectivamente.

\section{MÉTODO UTILIZADO}

A nálise da paleodose - Equipamento utilizado: TL/ OSL Automated Systems, Model 1100-series Daybreak N uclear Instruments Inc.

A nálise da dose anual - Equipamento utilizado: Canberra Inspector Portable Spectroscopy Workstation (NAI - TI)

\section{RESULTADOS}

Os resultados apresentados neste documento têm significação restrita e se aplicam somente ao espécime ensaiado ou calibrado.

A reprodução deste documento só poderá ser feita integralmente, sem nenhuma alteração.

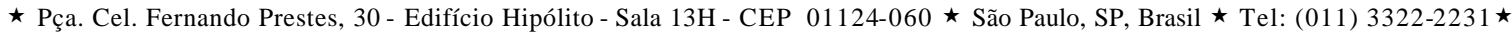

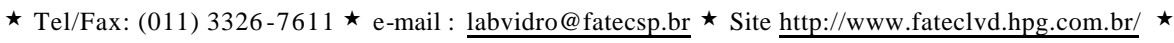




\section{Laboratório de Vidros e Datação}

\section{Faculdade de Tecnologia de São Paulo \\ Centro Estadual de Educação Tecnológica Paula Souza \\ VINCULADO E ASSOCIADO A UNESP}

Os resultados das paleodoses, doses anuais e das idades estão apresentados na Tabela 1, a seguir:

Tabela 1: Código LVD, amostra, dose anual, pal eodose e idade.

\begin{tabular}{|c|c|c|c|c|}
$\begin{array}{c}\text { Código } \\
\text { LVD }\end{array}$ & Amostra & $\begin{array}{c}\text { Dose Anual } \\
\text { (i Gy/ano) }\end{array}$ & $P(G y)$ & Idade (anos) \\
\hline ropke & & $1481 \pm 39$ & 2,51 & $1700 \pm 210$ \\
\hline scapini & 1846 & $1238 \pm 31$ & 2,0 & $1600 \pm 200$ \\
glanzel & 1874 & $1546 \pm 39$ & 0,99 & $640 \pm 80$ \\
\hline alberstat & 1826 & $1297 \pm 36$ & 1,42 & $1100 \pm 140$ \\
\hline
\end{tabular}

São Paulo, 11 de Maio de 2004. 
(Variables: est. $\mathrm{C} 13 / \mathrm{C} 12=-25:$ lab. mult $=1$ )

Laboratory number: Beta-181 184

Conventional radiocarbon ag $\mathrm{e}^{1}: \quad 470 \pm 50 \mathrm{BP}$

2 Sigma calibra ted result: Cal AD 1400 to 1490 (Ca I BP 550 to 460) ( $95 \%$ probability)

' $\mathrm{Cl} 3 / \mathrm{Cl} 2$ ratio estimated

Intercept data

Intercept of radiocarbon age

with calibration curve: Cal AD 1430 (Cal BP 520)

1 Sigma calibrated result: Cal AD 1420 to 1450 (Cal BP 530 to 500)

( $68 \%$ probability)

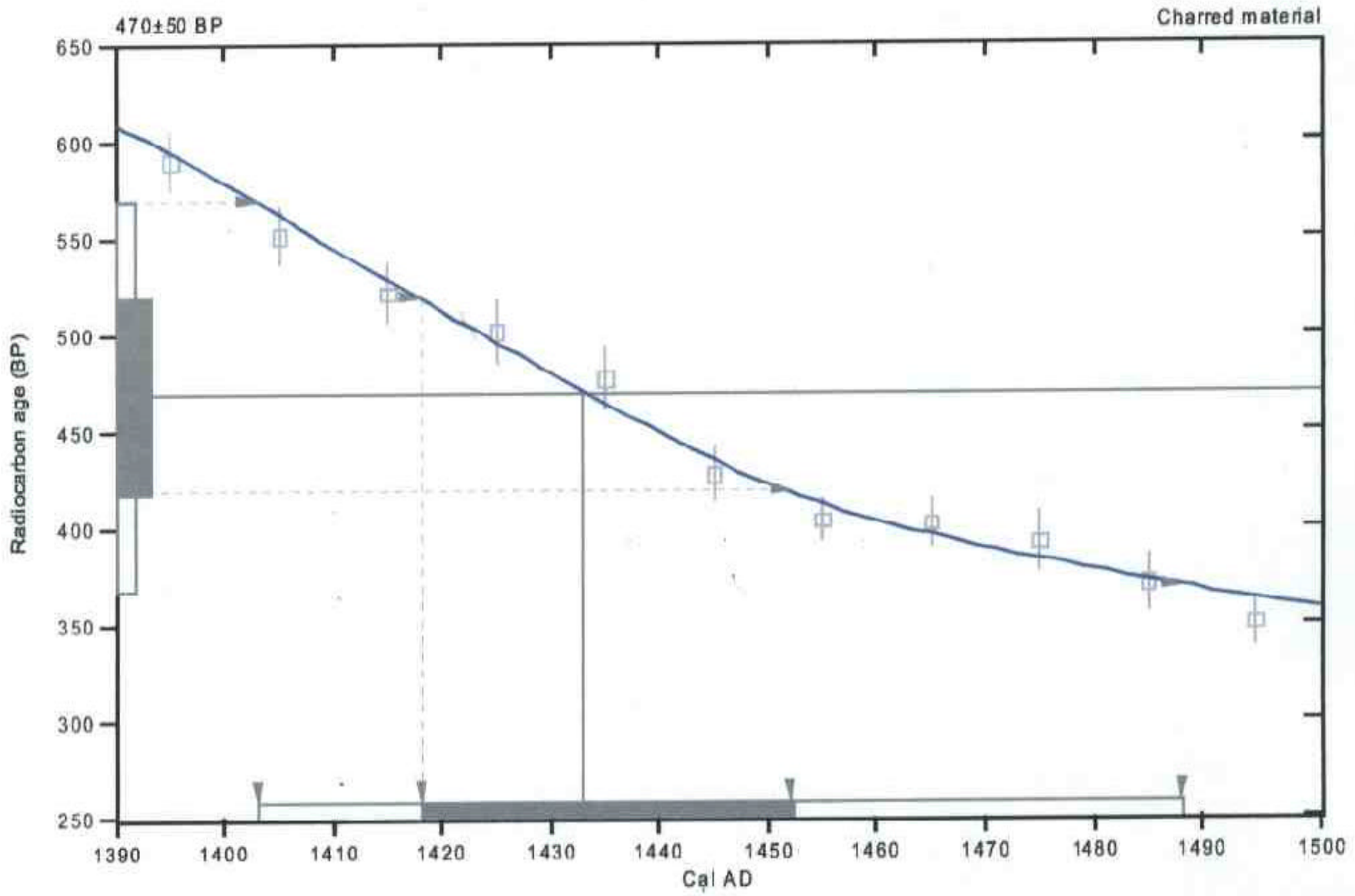

References:

Database used

INTC AL98

Calibration Database

Editorial Com ment

Stuiver, M., van der Plicht, H., 1998, Radiocarbon 40(3), pxii-xili

INTCAL98 Radiocarbon Age Calibration

Stutver, M., et. al., 1998, Radiocarbon 40(3), p1041-1083

Marh ematics

A Simplified Approach to Calibrating C14 Dates

Talma, A. S., Vogel, J. C., 1993, Radiocarbon 35(2), p317-322 